\title{
New Horizons in
}

Spanish Colonial Law

Contributions to Transnational Early Modern Legal History 

GLOBAL PERSPECTIVES

ON LEGAL HISTORY

3 


\title{
Global Perspectives on Legal History
}

\author{
A Max Planck Institute for European Legal History \\ Open Access Publication
}

http://global.rg.mpg.de

Series Editors: Thomas Duve, Stefan Vogenauer

\section{Volume 3}

Global Perspectives on Legal History is a book series edited and published by the Max Planck Institute for European Legal History, Frankfurt am Main, Germany.

As its title suggests, the series is designed to advance the scholarly research of legal historians worldwide who seek to transcend the established boundaries of national legal scholarship that typically sets the focus on a single, dominant modus of normativity and law. The series aims to privilege studies dedicated to reconstructing the historical evolution of normativity from a global perspective.

It includes monographs, editions of sources, and collaborative works. All titles in the series are available both as premium print-on-demand and in the open-access format. 
THOMAS DUVE

HEIKKI PIHLAJAMÄKI (EDS.)

New Horizons in

\section{Spanish Colonial Law}

Contributions to Transnational

Early Modern Legal History

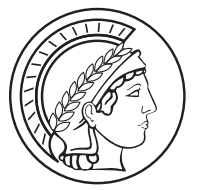

MAX PLANCK INSTITUTE

FOR EUROPEAN LEGAL HISTORY

2015 
ISBN 978-3-944773-02-5

eISBN 978-3-944773-12-4

ISSN 2196-9752

First published in 2015

Published by Max Planck Institute for European Legal History, Frankfurt am Main

Printed in Germany by epubli, Prinzessinnenstraße 20, 10969 Berlin

http://www.epubli.de

Max Planck Institute for European Legal History Open Access Publication

http://global.rg.mpg.de

Published under Creative Commons CC BY-NC-ND 3.0 DE

http://creativecommons.org/licenses/by-nc-nd/3.0/de

The Deutsche Nationalbibliothek lists this publication in the Deutsche Nationalbibliographie; detailed bibliographic data are available on the Internet at http://dnb.d-nb.de

Cover illustration:

Max Ernst, Humboldt Current, 1951-52, Öl auf Leinwand, $36 \times 61 \times 2 \mathrm{~cm}$, Fondation Beyeler, Riehen/Basel, Sammlung Beyeler, Foto: Robert Bayer, Basel, (c) VG Bild-Kunst, Bonn 2014

Cover design by Elmar Lixenfeld, Frankfurt am Main

Recommended citation:

Duve, Thomas, Pihlajamäki, Heikki (eds.) (2015), New Horizons in Spanish Colonial Law. Contributions to Transnational Early Modern Legal History, Global Perspectives on Legal History, Max Planck Institute for European Legal History Open Access Publication, Frankfurt am Main, http://dx.doi.org/10.12946/gplh3 


\section{Contents}

1| Thomas Duve, Heikki Pihlajamäki

Introduction: New Horizons of Derecho Indiano

9| Richard J. Ross

Spanish American and British American Law as Mirrors to Each

Other: Implications of the Missing Derecho Británico Indiano

29 | Rafael D. García Pérez

Revisiting the America's Colonial Status under the

Spanish Monarchy

75 | Tamar Herzog

Did European Law Turn American? Territory, Property and

Rights in an Atlantic World

97 | Heikki Pihlajamäki

The Westernization of Police Regulation: Spanish and

British Colonial Laws Compared

125 | Brian P. Owensby

The Theater of Conscience in the "Living Law" of the Indies

151| Ezequiel Abásolo

Víctor Tau Anzoátegui and the Legal Historiography of the Indies

161 | Luigi Nuzzo

Between America and Europe. The Strange Case of the derecho indiano

193 | Marta Lorente Sariñena

More than just Vestiges. Notes for the Study of Colonial Law History in Spanish America after 1808 
235 | Víctor Tau Anzoátegui

Provincial and Local Law of the Indies. A Research Program

257 | Contributors

VI Contents 
Thomas Duve

Heikki Pihlajamäki

\section{Introduction: New Horizons of Derecho Indiano}

The historiography of derecho indiano - a term traditionally employed by legal historians to refer to norms that were used in the overseas territories of the Spanish Crown in the early modern period - was essentially a creation of the Argentine historian Ricardo Levene (1885-1958). His first publication on Spanish colonial law, Introducción al estudio del derecho Indiano (1916), can largely be viewed as a foundational work for the discipline in conjunction with subsequent publications that further elaborate on this topic (e. g. Levene 1918, 1924). Between the late 1930s and 1940s, other scholars, like Rafael Altamira (Altamira 1938, 1939, 1948), Jorge Basadre (1937), Ots Capdequi (1943), and Manuel Belaunde Guinassi (1947), took it upon themselves to build on the notion of derecho indiano and in general on Levene's work, which itself had been influenced by his own teachers and developed in close collaboration with other jurists and historians (Levene 1953; Tau Anzoátegui 1990, 2006). From the 1950s on, Alfonso García-Gallo of Spain emerged as the leading scholar in the field (García-Gallo 1951, 1952, 1953, 1955). For the next three decades, his writings would set the agenda for legal historical studies on the overseas territories of the Spanish crown. Together with Alamiro Ávila-Martel and Ricardo Zorraquín Becú, García-Gallo founded the Instituto Internacional de la Historia del Derecho Indiano (IIHDI) in 1966. With his keynote address entitled Problemas metodológicos de la historia del derecho indiano (García-Gallo, 1967), held at the first international meeting of legal historians working on the derecho indiano, he set the agenda for further research. In his subsequent works, he presented important reflections and advances in research methods and key topics concerning derecho indiano (García-Gallo 1970, 1972, 1987). In this regard, the manifold contributions of scholars from both sides of the Atlantic cannot be emphasized enough, for it is no exaggeration to state that for more than two decades, both Latin American and Spanish scholarship relied on the epistemic framework delineated by García-Gallo, to which leading scholars of the subsequent generation, like Tau Anzoátegui (1993), Martiré (1996), and 
Sánchez Bella (1996), testify. Moreover, since its foundation, the IIHDI has been organizing a series of congresses at locations alternating between Spain and Latin America. This has helped to build a transnational scholarly community that serves as a forum for debates and scholarly exchanges. The published acta of the IIHDI conferences provide an excellent window to the state of the research within the field between the 1970s and the 1990s (De la Hera et al., 1989). ${ }^{1}$

Nearly thirty years later, in 1995 , the $11^{\text {th }}$ Congress of the same Institute, held in Buenos Aires, heralded the revival of the discipline, when the Argentinian legal historian, Víctor Tau Anzoátegui, seized the opportunity to address questions on methodology and on the future orientations of the discipline. In so doing, he also invoked the writings of European legal historians like Paolo Grossi, Antonio Manuel Hespanha, Bartolomé Clavero, and others. At the same time, he drew on his own intense legal historical research carried out in the previous decades, starting with research on the codification of civil law in Argentina (Tau Anzoátegui 1977) and working his way through to the foundational structures of derecho indiano (Tau Anzoátegui 1992), demonstrating sound historiographical reflection (Tau Anzoátegui $1990,1993,1996)$. His inaugural lecture at the $11^{\text {th }}$ Congress, which was published in 1997 under the title Nuevos Horizontes en el Estudio Histórico del Derecho Indiano (Tau Anzoátegui 1997), can be considered part of a broader tendency to revisit and reflect upon the early scholarship on derecho indiano undertaken by the first two generations of legal historians from Latin America and Europe, especially from Spain, that generated comprehensive bibliographical studies in the 1980s and the 1990s. ${ }^{2}$

At the outset, Tau Anzoátegui proposes going beyond conceiving the paradigm of legal history purely as a history of legal norms. He first describes the Methodenstreit of the 1970s, which had considerable influence on how legal history - and Spanish colonial law - was understood, in that either

1 For a list of the Congresses with a complete digital library of all the publications of the Congress see: http:/web.ua.es/es/institutoderechoindiano/.

2 Outstanding in this context is the work of Dagrossa (1998); see also Bernal Gómez (1989); De la Hera et al. (1989); Floris Margadant (2000); González (1995); Mariluz Urquíjo (1990); Martiré (2003); Muro Romero (1996); Salinas Araneda (1984, 1994, 1998); Sánchez Bello (1989, 1990); Tau Anzoátegui (1996); Zorraquín Becú (1995), (1997). 
some scholars emphasized the character of the discipline as a legal science (García-Gallo, Zorraquín Becú), while others, mainly Spanish scholars, such as Francisco Tomás y Valiente and Bartolomé Clavero, chose to situate legal history within a social science framework. Tau Anzoátegui now linked the methodological development of legal history to what he called "the posture superseding rational and statutory state law,"3 so that normativity, as it was now being conceived by scholars, related more to the autonomy of different levels of social organization, different modes of normative creativity, diverse notions of law and justice, the jurist's position as an artifact of law, and the casuistic character of legal decisions. All of these, according to Tau Anzoátegui, were now to be seen as alternatives to the old conception of law as a matter of state hegemony. This changed conception of modern law opened up new horizons for legal historians and scholars of Spanish colonial law, aiding them to broaden their understanding of the workings of previous laws. ${ }^{4}$ But the wider conception of normativity advocated by Tau Anzoátegui also led him to make an appeal to the legal historians to use a broader array of sources in the study of legal norms than just the textual sources. Scholars had to "substitute the legalist culture for a juridical culture, which would permit [the scholar] to place the law in its proper place within the [social] system, depending on the substance and the epoch, and which would enable an 'intelligent reading' - which is neither ingenuous nor malicious - of the legal texts, asking them questions in the light of a wide conception of the legal phenomenon." 5

Furthermore, Tau Anzoátegui elevated certain areas of Spanish colonial law, which he thought deserved more attention than they had hitherto received. One such area was the history of the learned jurist, or the letrado, who was to be studied within the social, political, economic and bureaucratic context. Another neglected area that Tau Anzoátegui identified was book history: the circulation of printed books, libraries, and the different

3 «[...] una postura superadora del dominante Derecho racional, estatal y legal.», TAU Anzoátegui (1997) 20.

4 Tau Anzoátegui (1997) 19-20.

5 Tau Anzoátegui (1997) 43. «[...] reemplazar la cultura legalista por la cultura jurídica, que permita colocar a la ley dentro del ordenamiento en su verdadero lugar, según la materia y las época, y que posibilite una 'lectura inteligente' - que no es ingenua ni maliciosa - de los textos legales, interrogándolos a la luz de una concepción amplia del fenómeno jurídico.» 
interpretations of legal texts. Provincial and local derecho indiano had received scant scholarly attention, so that even a "microhistory" was well within the scope of the endeavor. And last but not least, Tau Anzoátegui wished to see more scholarship on the "continuities and ruptures" of colonial legal legacy in the nineteenth century, in the aftermath of the colonial period. $^{6}$

Tau Anzoátegui's "new horizons" were thus wide open: even if he had not envisaged a comprehensive revolution of the field, his program paved the way for revising the history of Spanish colonial law in order to gain a radically new understanding of it. While his positions were far from radical as far as historical scholarship was concerned, within the mainstream Latin American legal history and derecho indiano, his voice was authoritative. There is no doubt that areas of research in many fields that Tau Anzoátegui identified as important have witnessed major progress in the ensuing two decades.

However, in the seventeen years that have passed since Tau Anzoátegui's programmatic declaration first appeared, new challenges have also emerged. The challenges of globalization are felt both in the historical and the legal sciences, and thus, unsurprisingly, also in the field of legal history. Broader issues have experienced resurgence as a result, for instance, the importance accorded to religious normativity within the normative setting of societies is a direct result of that. They have raised awareness of the need to reconceive the circulation of ideas and juridical practices, and reiterated the significance of drawing attention to the layers of cultural translation that these ideas underwent in the process of reinterpretation in different contexts. Not least, the growing consciousness of and the strong call to reconsider and interrogate colonial history from the postcolonial perspective unexpectedly necessitated a thorough reexamination of the foundational concepts of the discipline. What concept of law best serves our historical studies in consideration of the multinormative settings? How do we define the spatial dimension of our work? How do we analyze the entanglements in legal history? Even if the answer may at first glance seem rather easy, endless controversies have erupted every time scholars have tried to redefine these pivotal terms.

The aim of this volume is not to serve in the same capacity as Tau Anzoátegui's book from 1997, which essentially reoriented a whole discipline's

6 Tau Anzoátegui (1997) 57-126. 
research agenda. Rather, it draws rich insights from Tau Anzoátegui's work in order to address some new challenges confronting the discipline. Not least, it hopes to help to integrate the study on derecho indiano into a broader field, especially with research in the English-speaking world. It starts and ends with some considerations regarding the historiography of derecho Indiano: Luigi Nuzzo's introduction reflects upon the history of the historiography, and Ezequiel Abásolo offers a dedication to Tau Anzoátegui's work. Richard Ross, Tamar Herzog and Heikki Pihlajamäki present three studies, which integrate derecho indiano into an Atlantic perspective. Brian Owensby, Marta Lorente and Víctor Tau Anzoátegui take up key aspects that Tau Anzoátegui had raised in his Nuevos Horizontes.

Together, the contributions, which were the result of a small workshop in Berlin, in June 2012, show that many of Tau Anzoátegui's wishes, which he expressed in Nuevos Horizontes in 1997, have indeed borne fruit. But even if considerable results have been achieved. It is equally clear that new demands are being placed on the study of derecho indiano. Some of the new questions have been treated in this volume, but much remains to be done. Twenty years after the $11^{\text {th }}$ Congress of the IIHDI, where Tau Anzoátegui presented his reflections on Nuevos Horizontes, many of these challenges will have to be discussed on a global scale. If this volume helps to shed light on these New Horizons, its goal will have been achieved.

\section{Bibliography}

Altamira, Rafael (1938), La legislación indiana como elemento de la historia de las ideas coloniales españolas, in: Revista de Historia de América 1, 1-24

Altamira, Rafael (1939), Técnica de la investigación en la historia del derecho indiano, México

Altamira, Rafael (1948), Manual de investigación de la historia del derecho indiano, México

Basadre, Jorge (1937), Historia del derecho peruano (Nociones generales. Epoca prehispánica. Fuentes de la época colonial), Lima

Bernal Gómez, Beatriz (1989), Historiografía jurídica indiana, in: Anuario Mexicano de Historia del Derecho 1, 15-45

Belaúnde Guinassi, Manuel (1947), Consideraciones sobre el derecho indiano, in: Derecho, Pontificia Universidad Católica del Perú 7, 51-63 
Dagrossa, Norberto (1998), Bibliografía de la historia del Derecho Indiano, publicado en: Andrés-Gallego, José (ed.), Nuevas aportaciones a la Historia Jurídica de Iberoamérica, Madrid: Fundación Histórica Tavera/Fundación Hernando de Larramendi (= Colección Proyectos Históricos Tavera, I, CDROM, DIGIBIS)

De la Hera, Alberto, Ana María Barrero García, Rosa María Martínez de Codes (1989), La historia del derecho indiano. Aportaciones del Instituto Internacional de historia del derecho indiano a la bibliografía jurídica americanista, Madrid

Floris Margadant, Guillermo (2000), Evolución de la investigación del derecho indiano, México

García-Gallo, Alfonso (1951), El derecho indiano y la independencia de América, in: Revista de Estudios Políticos 50, 141-161

García-Gallo, Alfonso (1952), Panorama actual de los estudios de historia del derecho indiano, in: Revista de la Universidad de Madrid 1, 41-64

García-Gallo, Alfonso (1953), El desarrollo de la historiografía jurídica indiana, in: Revista de Estudios Políticos 70, 163-185

García-Gallo, Alfonso (1955), El derecho común ante el Nuevo Mundo, in: Revista de Estudios Políticos 80, 133-152

García-Gallo, Alfonso (1967), Problemas metodológicos de la historia del derecho indiano, in: Revista de Historia del Derecho 18, 13-64

García-Gallo, Alfonso (1970), Metodología de la historia del derecho indiano, Santiago

García-Gallo, Alfonso (1972), Estudios de historia del derecho indiano, Madrid

García Gallo, Alfonso (1987), Los orígenes españoles de las instituciones americanas. Estudios de derecho indiano, Madrid

González, María del Refugio (1995), El derecho indiano y el derecho provincial novohispano: marco historiográfico y conceptual, México

Levene, Ricardo (1916), Introducción al estudio del derecho indiano, Buenos Aires

Levene, Ricardo (1918), Notas para el estudio del Derecho Indiano, Buenos Aires

Levene, Ricardo (1924), Introducción a la historia del derecho indiano, Buenos Aires

Levene, Ricardo (1953), La concepción de Eduardo de Hinojosa sobre la Historia de las ideas políticas y jurídicas en el Derecho español y su proyección en el derecho Indiano, in: Annuario de Historia del Derecho español XXIII/46, 259-287

Mariluz Urquijo, José María (1990), Historiografía sobre el derecho indiano, in: Historiografía argentina (1958-1988). Una evaluación crítica de la producción histórica argentina, Buenos Aires, 13-20

Martiré, Eduardo (1996), Alfonso García-Gallo y el Instituto Internacional de Historia del derecho indiano, in: Homenaje al Profesor Alfonso García-Gallo, Madrid, 1, 69-88 
Martiré, Eduardo (2003), Algo más sobre Derecho Indiano (entre el 'ius commune' medieval y la modernidad), in: Anuario de Historia del Derecho Español 73, 231-265

Muro Romero, Fernando (1996), Consideraciones sobre el porvenir historiográfico del derecho indiano, in: Homenaje al Profesor Alfonso García-Gallo, Madrid, 4, 133-140

Ots Capdequi, José (1943), Manual de historia del derecho español en las Indias y del derecho propiamente indiano, Buenos Aires

Salinas Araneda, Carlos (1984), Avance para una bibliografía chilena de historia del derecho indiano, in: Revista de Estudios Histórico-Jurídicos, Valparaíso, 9, 303-429

Salinas Araneda, Carlos (1994), El derecho canónico indiano en la bibliografía de una década: apuntes para un balance, in: Revista de Estudios Histórico-Jurídi$\cos 16,149-213$

Salinas Araneda, Carlos (1998), La historiografía canónica reciente sobre Concilios y Sínodos indianos 1980-1996, in: Linehan, Peter (ed.), Life, Law and Letters: Historical Studies in Honour of Antonio García y García, Rom, 749-759

Sánchez Bella, Ismael (1989), Historiografía de las instituciones jurídicas indianas (1945-1987), in: Balance de historiografía sobre Iberoamérica: 1945-1988: actas de las IV Conversaciones Internacionales de Historia, Pamplona, 291-345

Sánchez Bella, Ismael (1990), Aportación española a la historia del derecho indiano (1940-1989), in: Revista de Indias 188, 51-76

Sánchez Bella, Ismael (1996), García-Gallo y el derecho indiano, in: Homenaje al Profesor Alfonso García-Gallo, Madrid, 1, 165-175

Tau Anzoátegui, Víctor (1977), La codificación en Argentina (1810-1870). Mentalidad social e ideas jurídicas, Buenos Aires

TAu Anzoátegui, Víctor (1990), Altamira y Levene: una amistad y un paralelismo intelectual, in: Cuadernos del Instituto de Investigaciones Jurídicas 15, 475-492

Tau Anzoátegui, Víctor (1992a), Casuismo y Sistema: Indagación histórica sobre el espíritu del Derecho Indiano, Instituto de Investigaciones de Historia del Derecho, Buenos Aires

Tau Anzoátegui, Víctor (1992b), La ley en América hispana. Desde el descubrimiento a la emancipación, Buenos Aires

TAu Anzoátegui, Víctor (1993), El tejido histórico del derecho indiano: las ideas directivas de Alfonso García-Gallo, in: Revista de Historia del Derecho 21, 9-72

TAu Anzoátegui, Víctor (1996), Las tradiciones historiográficas en el estudio del Derecho indiano, in: Revista de Historia del Derecho 24, 549-556

Tau Anzoátegui, Víctor (1997), Nuevos horizontes en el estudio histórico del derecho indiano, Buenos Aires 
Tau Anzoátegui, Víctor (2006), De la sociología al derecho indiano. Contrapuntos entre Ricardo Levene y Ernesto Quesada, in: Revista de Historia del Derecho 34, 357-417

Zorraquín Becú, Ricardo (1995), Las aspiraciones del derecho indiano y los resultados conseguidos, in: Instituto Internacional de Historia del Derecho Indiano (ed.), Memoria del X Congreso del Instituto Internacional de Historia del Derecho Indiano, Escuela Libre de Derecho, México D. F., 1767-1804

Zorraquín Becú, Ricardo (1997), Nuevas consideraciones sobre el Derecho indiano, in: Revista de Historia del Derecho 25, 501-524 


\section{Spanish American and British American Law as Mirrors to Each Other: Implications of the Missing Derecho Británico Indiano}

Most of the essays in this volume, proceeding in the spirit of Victor Tau Anzoátegui's distinguished scholarship, pursue "new horizons" in the study of Spanish American law. Co-editors Thomas Duve and Heikki Pihlajamäki charged me with a different mission. They asked me, a student of British North American law in an Atlantic framework, to compare the legal history of the Spanish and British empires with one eye on Tau Anzoátegui's work and the other on the papers produced for the volume.

If there is a concept central to both Tau Anzoátegui's writings and to many of the essays in this volume, it is the derecho indiano - its meaning, implications, development, and variability, and the changing ways that scholars have understood it. From the perspective of the English Atlantic, what stands out is the lack of an analogous notion that refers to the collective legal order of the British North American colonies. ${ }^{1}$ Section I of this essay will explore why scholars of the English Atlantic do not think in terms of a derecho británico indiano. Its absence has powerfully shaped scholarship on the intellectual history of law (Section II) and on the trajectories of change perceived in the legal development of the two empires (Section III).

\section{Derecho Indiano and the (Missing) British American Continental Legal Order}

Historians of Spanish American law have put the concept of the "derecho indiano" at the center of their field. This is true whether they treat the term restrictively as a shorthand for legal doctrines, institutions, and personnel, or whether, more expansively, they include within the term, as Tau does, the

1 I will focus on the colonies that became the United States. Strictly speaking, the British Atlantic would have included English Canada and the English Caribbean. 
values and "spirit" of the law and the interactions with politics and the wider society that animated the juridical order. The ongoing learned debates over the nature and meaning of the derecho indiano have made the term highly contested, which has only underscored its importance as an object of study. Indeed, historians who go so far as to recast the derecho indiano less as a set of doctrines than as an intellectual culture, and who contend that its successes and failures owed less to its institutional framework than to the social networks and political interests surrounding those institutions, nonetheless insist on its centrality as the starting point for discussing Spanish American law. Some of the papers in this conference - for instance, by Ezequiel Abásolo, Luigi Nuzzo, and Heikki Pihlajamäki - represent the third generation of reflection on these themes, if we consider Tau and his contemporaries the second generation, and their predecessors such as Ricardo Levene and Rafael Altamira the first generation. ${ }^{2}$

Historians of British American law, looking upon all of this, are impressed by the sophistication and intensity of these debates. But even more, they are struck by the absence of a workable analogue in their world to the derecho indiano. When they discuss the legal orders of the British Atlantic, they think in terms of "constitutions," distinguishing among three types. First, a mix of charters, bills of rights, statutes, longstanding institutions, and customs organized, or "constituted," power within Great Britain itself. Second, each colony in America developed its own constitution, commonly resting on its charter, supplemented by colonial statutes, customs, and habits of wielding power. Third, an unstable, disputed "imperial constitution," built out of conventions accumulating from the latter seventeenth century onward, structured government between Britain and its colonies across the Atlantic. Each colony handled local affairs, while the Crown and parliament oversaw matters of general concern such as war and peace, diplomatic affairs, coinage, and intercolonial and foreign commerce. The Empire provided a structure for review of colonial legislation by the Crown's Privy Council and for appeal of judgments by colonial supreme courts. With characteristic unclarity, the imperial constitution offered choice of law rules suggesting when colonies might develop their own particular law, when they might deploy the diverse array of sources contained within the rubric

2 Aвásolo (2015); Nuzzo (2015); PihlajamäKi (2015). 
of the "laws of England," and when English law would override "repugnant" colonial ordinances. ${ }^{3}$

Conspicuously absent among these three constitutions was a fourth: a collective legal order of the colonies of the English Atlantic, a derecho británico indiano. Is this concept seldom found in the writings of scholars of British America because they had no political or ideological reason to invent it? The formation of the notion of a Spanish American derecho indiano is instructive here. The concept, developed by Ricardo Levene, came into use among historians only in the middle third of the twentieth century. It allowed scholars to treat the law of the Spanish Indies from a cosmopolitan, pan-Hispanic perspective that escaped from the limitations of national historiography. To speak of a derecho indiano was to emphasize how the various Latin American nations shared a legal-cultural inheritance, an inheritance that their forebears had not merely received from Castile but had helped construct. ${ }^{4}$ There was no corresponding need to deploy a legal historical concept to underscore the common heritage of the constituent parts of the United States since it was already a single nation rather than, as in Latin America, a grouping of independent countries created out of a once unified empire.

Ideology and politics aside, the more significant reason why historians do not think in terms of a derecho británico indiano is that the historical record is not conducive. Suppose, as a thought experiment, we imagine what a hypothetical derecho británico indiano would have looked like. Its features can be modeled, by analogy, on the Spanish American derecho indiano. The purpose of this thought experiment is not to argue that a derecho británico indiano actually existed in any meaningful sense and has been overlooked. Not until the closing stages of the colonial period do hints of one emerge. Rather, the point is, ultimately, to invite reflection on the implications of Spanish American - but not British American - legal history being organized around the study of a collective continental legal order.

3 Greene (1987) 67-68, 74-76; Greene (2011) 49-54, 63-66. See also Bilder (2004) 1-4; Brown (1964) 1-22; Hulsebosch (2005) 72-74; Hulsebosch (1998) 319-379; Sмith (1950); SмITH (1969); SмITH (1970).

4 Pihlajamäki (2010); Pihlajamäki (2015); Nuzzo (2015). Cf. Tau (1997) 28-33, which contends that the work of García-Gallo more than Levene's made "derecho indiano" the central concept for the field. 
A derecho británico indiano would have included, first, an array of institutions that recurred from colony to colony (akin to the audiencias, cabildos, corregidores, and so forth that could be found in New Spain, Peru, and other areas). Second, this collective legal order of the English American colonies would have expressed through law a dominant set of ideological and political commitments spanning the continent. In the case of the Spanish Empire, these included, for instance, the representation of the king as a guarantor of justice to his vassals, a commitment to evangelization, and a disdain for representative assemblies. Third, the collective legal order would have had a branch of law for overseeing a unified religious establishment. Fourth, it would have included principles determining which situations would be governed by indigenous customs and which by fusions of indigenous and settler law. Fifth and finally, a sizable corpus of law issued from the metropolis and governing day to day life in the colonies - something akin to what the Spanish Empire collected in the Recopilacion - would have brought some unity to an English collective legal order. But in reality, as opposed to in our thought experiment, the different English settlements disagreed in their religious and secular institutions, ideological commitments, policies towards native law, and social and economic legislation.

As a result, historians sometimes treat the law of each English colony as a singular entity (the law of Massachusetts, of Virginia, and so forth). Or, more commonly, they think in terms of regions, with some dispute about how to organize them. A typical division includes New England, the Middle Colonies or the Delaware Valley, the Chesapeake, the Deep South, and the Caribbean islands. To be sure, students of the Spanish American derecho indiano also assume regionalism - but of a different sort. Peripheral settlements, they note, employed varieties of the derecho indiano less learned than the versions that obtained in the cores of New Spain and Peru. The choice of law rules contained within the derecho indiano allowed corporations, indigenous communities, and viceroys, audiencias, cabildos, and other governing institutions to create norms that differed from place to place. The geographical variation that was expected, even praised, within the derecho indiano did not call into question its primacy as the overall framework for Spanish American law. ${ }^{5}$

5 Altamira (1945) 144-183; Cutter (1995) 32-43; González (1995) 11-67; Tau (1992a) 181-183, 313-319; TAU (2001) 53-79, 96-100, 151; TAU (1997) 85-92.

12 Richard J. Ross 
By contrast, the regionalism of British American law was of a more profound character. Seventeenth century settlers came over with widely varying goals, forming colonies at different points in time with distinct institutional structures and legal cultures. First, where the sixteenth century Spanish Empire imposed Castilian-governing institutions upon New Spain and Peru, the English Empire insisted on no comparable similarities among its various colonies. ${ }^{6}$ The mode of appointment of senior executive and judicial officials differed among colonies. The governor and his council commonly nominated judges and subordinate executive officials and served as an appellate tribunal. The governor and council owed their appointment variously to the king (in "royal" colonies such as Virginia), or to private individuals who "owned" settlements (in "proprietary" colonies such as Pennsylvania), or to popular election (in "corporate" colonies such as Connecticut).

Second, institutional and legal cultural variation occurred because the initial settlers who established colonies selected among institutions and legal norms familiar from home, adopting some, reshaping or rejecting others, in regionally specific processes. Consider the contrast between Massachusetts (the dominant colony in New England) and Virginia (the leading colony in the Chesapeake). Committed Puritans led the settlement of early Massachusetts. Determined to create a more righteous and Christianized society, they insisted that the state and churches work together in guiding or driving people toward moral regeneration. Church members alone voted in colony-wide elections in order to preserve control by the godly. Yet within the confines of this religious mission, the colony strove for a communal and consensual model of authority. Settlers annually elected their officials and participated widely in local offices. Massachusetts codified its laws and provided decentralized tribunals at the county and town level, dispensing prompt and relatively nontechnical justice. Virginia planters, by contrast, primarily sought material gain rather than social regeneration. Tobacco barons who controlled land and servant labor exercised legal authority as a result of their economic and social prominence. Virginia notables dispensed a style of justice more authoritarian than the colonial norm in order to govern an agitated population that was disproportionately young and male. 
The primary unit of government was the county rather than the town (as in Massachusetts). The colony's slight institutional presence beneath the county level and its dispersed settlement, heavy-handed elite, and propensity towards violence combined to undercut the effectiveness of legal decisions. The most distinctive feature of Virginia and the other southern and Caribbean colonies was the law of slavery. England did not have a law of slavery itself, nor did it create a slave code for its American colonies in the fashion of the French and Spanish empires. Virginia and the Southern and Caribbean colonies, but not Massachusetts, developed the distinctive policing apparatus that accompanied slave law. Masters, for example, enjoyed legal protection if they accidentally beat slaves to death; colonies offered public support for the private recapture or killing of runaways; and restrictions were placed on the ability of whites and slaves to socialize and trade with each other. ${ }^{7}$

Space restrictions preclude comparing other regions in seventeenth century English America. But the contrast of Massachusetts and Virginia suggest a conclusion: The profound regionalism of British America appears far less as a set of variations within a shared legal order than does Spanish American regionalism, which grew up under the framework of the derecho indiano. The absence of a derecho británico indiano has shaped how scholars have pursued the legal history of the two empires. This is apparent in the study of the intellectual history of law.

\section{Intellectual History}

On occasion similar questions have driven the intellectual history of British and Spanish American law. Historians have explored both empires' justifications for colonization and dispossession of indigenous peoples. And they have stressed the prominence of law as a political vocabulary for negotiating with imperial administrators. Yet for all this, significant differences stand out in how scholars have pursued the intellectual history of law in the two empires. First, in the mix of approaches to legal history, intellectual history occupies a more prominent place in Spanish American than in British American historiography. This is, in part, the result of the much greater amount of intellectual "raw material" in Spanish America. Since so many key administrators of the Empire were letrados, they left behind much more high-level

7 Konig (2008); Nelson (2008) 3-79; Tomlins (2010) 221-226, 267. 
intellectual reflection on law than did their British counterparts, who were typically laymen. There was no counterpart in the British Empire to the great importance of neo-Thomist legal theory among churchmen and jurists, which inspired reflection on the intersection of eternal law, natural law, and positive law in both state and church. British Protestants, lacking oracular confession, did not produce manuals for confessors. Confessor manuals undertook a sustained engagement with law by asking which ordinances bound conscience (as per Romans 13:5), and determining whether violation of laws binding conscience subjected the offender to mortal sin or only to venial sin. Scholars seeking to write intellectual histories of Spanish American law have much more to work with than British American historians.

The absence of a derecho británico indiano helps account for a second difference. Intellectual histories of British American law, particularly in the seventeenth century, organize themselves regionally to such an extent as to downplay commonalities among the various settlements. By contrast, the more plentiful intellectual histories of Spanish American law typically treat the New World as a unit harboring variations rather than as a series of lightly connected regions. In support of this proposition, consider some of the distinguished intellectual histories of Spanish American law produced by Tau and by participants in this volume. First, Tau has famously written on the transition in the Spanish American Empire from a predominantly casuistical style of legal reasoning towards one that is more reliant on systemization. ${ }^{8}$ Brian Owensby's essay extends Tau's framework by exploring the treatment in Spanish American legal culture of conscience, simultaneously the means and end of casuistry. ${ }^{9}$ Second, Tau and others have stressed the importance of natural law and the "common good" within Spanish American legal reasoning. This work has several variants. "Common good" and natural law might be treated as a touchstone for assessing whether positive laws and customs are valid or not and whether officials might suspend ordinances by invoking the formula "obedezco pero no cumplo" ["I obey, but do not comply"]. ${ }^{10}$ Or one might argue that for all the legalistic rhetoric of the Spanish Empire, officials based their actions far more on natural law, religious injunctions, and amorphous, self-interested notions of the com-

8 TAU (1992b).

9 Owensby (2015).

10 TAU (2002); TAU (1992a) 59-126; TAU (2001) 143. 
mon good than on the requirements of positive law. ${ }^{\mathbf{1 1}}$ Or the common good and natural law might be taken as the measure of the respective obligations of the Crown, officials, and vassals in a just social order. From this perspective, the identification of the common good and natural law would be the key to resolving disputes in areas as diverse as amparo petitions, land composiciones, citizenship [vecindad], and Indian labor and tribute requirements. ${ }^{\mathbf{1 2}}$ Historians pursuing each of these topics have mixed evidence from New Spain, Peru, the Yucatan, and other regions. In so doing, they adopted a continental perspective.

In contrast to Spanish American historiography, the legal-intellectual history of British American casuistry and conscience, common good, and natural law commonly follows regional lines from settlement through, roughly, the middle third of the eighteenth century. To be sure, the broadest outlines of these intellectual frameworks were similar in the various regions of the English Atlantic. But in the mid-level propositions, in the ways that settlers drew upon and applied these overall frameworks, the regions differed. Let us begin with the notion of the "common good." Jacobean promoters of Virginia promised "honor and glory" to settlers who pursued the common good of the new colony rather than their own self-interest. ${ }^{13}$ Massachusetts' leaders emphasized the honor of God rather than personal glory, producing a differently inflected notion of the common good, one linked to the religious mission of the colony. Both Massachusetts and Virginia settlers thought about the common good in the Ciceronian idiom characteristic of early modern Europe, which implored citizens to identify their private good with the collective, shared good of their community. This framework recognized that since communities varied, so would the particular form of the common good that each pursued. ${ }^{14}$ The common good defined by the leaders of Puritan Massachusetts would naturally differ from that of slaveholding Virginia, from Quaker Pennsylvania, and from heterogeneous New York with its substantial Dutch population.

Understandings of conscience and casuistry likewise varied regionally. New England Puritans, Rhode Islander dissidents inspired by Roger Wil-

11 See, e. g., Herzog (2004); Herzog (1995).

12 Herzog (2015); Herzog (2003); Owensby (2008); De Solórzano Pereira (1996) 206-275 (Indian labor requirements).

13 Fitzmaurice (2003) 77.

14 Miller (1994) 2-3, 21-87.

16 Richard J. Ross 
liams, and Pennsylvania Quakers, far more than settlers in the slaveholding south, made conscience a central category of their political life and legal culture and studied casuistical (or "cases of conscience") literature. Historians consequently either organize studies of early American conscience and casuistry by colony or make sure to elucidate the differences among the settlements. ${ }^{15}$ Along with Connecticut and New Haven colonies, but distinct from settlements outside of New England, Massachusetts drew on the judicial law of Moses to establish the obligations of conscience. ${ }^{16}$ Massachusetts' ministers and magistrates used casuistical reasoning to reconcile the godly mission of their colony with the practical exigencies of reason of state, including the need to maintain religious unity. They held that the state might coerce dissenters from Puritan fundamentals on the grounds that these wayward settlers had sinned against their own conscience. Roger Williams, exiled out of Massachusetts to help found Rhode Island, famously drew the opposite conclusion and denied the right of the civil magistrates to pressure Christian believers whose conscience led them to minority views. William Penn, the organizer of Pennsylvania, synthesized the leading arguments for religious liberty of conscience circulating in mid-seventeenth century England and adjusted them for a colonial context - believing, for example, that tolerance would encourage responsible people to immigrate to his colony and would reduce the factionalism epidemic in new settlements. ${ }^{17}$ The regional rather than continental nature of the legal-intellectual history of the British Empire before the middle third of the eighteenth century is a subset of - and further proof of - the absence of a common legal order, of a derecho británico indiano.

But by the mid-eighteenth century, pronounced regional variations began to abate. Consider natural law. The law of nature supplied arguments deployed across the different colonies to justify English sovereignty over North America and the rules for dispossessing native Americans. ${ }^{\mathbf{1 8}}$ Regional variation occurred when leaders of the various colonies drew on natural law

15 For examples of the former, see Mosse (1957) [Massachusetts]; Morgan (1967) 130-142 [Rhode Island]; Gaustad (1991) [Rhode Island]; Dunn (1967) [Pennsylvania]. For an example of the latter, see, e.g., Murphy (2001).

16 On which, see Ross (2012).

17 Mosse (1957) 88-106, 132-145; Murphy (2001) 48-55, 58-60, 173-181.

18 Fitzmaurice (2003) 137-149, 158; Pagden (1995); Tomlins (2010) 93-132; Yirush (2011) $12-13$. 
to discern the obligations of conscience or to define the common good in their differing communities. ${ }^{19}$ By the middle third of the eighteenth century, these uses subsided while settlers resisting an intrusive British Empire increasingly drew on natural law as a resource against the Crown and imperial administrators. Colonists claimed that their natural right to migrate to America, enter upon its unimproved open lands, and form political societies implied a further right to dispossess natives beyond what the Crown would allow and to claim the full protection of English common law against royal and proprietary efforts to limit its applicability. In the decade of agitation leading to the American Revolution, controversialists included natural law among their arsenal of arguments. ${ }^{20}$ From the mid-eighteenth century onward, then, variations in the use and interpretation of natural law tracked more onto political factions (prerogative vs. popular parties and Whig vs. Tory) than onto regions, as was the case in the seventeenth century. There was, in short, at least a partial convergence among regions in their treatment of natural law. This convergence encouraged scholars to write legal-intellectual histories of the Revolutionary era less in regional frameworks than on a continental-wide scale (in the style of Spanish American legal-intellectual historiography). With this in mind, we might ask whether the term "convergence" meaningfully describes the overall direction of change in other aspects of British American legal culture, and in Spanish American law.

\section{Trajectories of Change in Spanish and British American Law}

The initially regional organization of the British American legal systems powerfully shapes the story that scholars tell about the transition of colonial law from the seventeenth to eighteenth century. The perceived trajectory of change differs significantly from that in Spanish America. Let us start with the latter. Historians of Spanish American law speak of how a framework established by roughly the 1570 s underwent a long, gradual period of stabilization, maturation, or consolidation until, arguably, the 1750s. The derecho indiano in the center of this picture underwent, it is said, continual but incremental change. Tau's history of the relative shift from casuistical to

19 Adding to the complexity, minority ethnic groups such as the Germans cultivated differently inflected understandings of natural law. See Roeber (2001).

20 Botein (1980); Wright (1931) 13-99; Yirush (2011) 17, 138, 156, 223-258. 
systematic reasoning might be read in this vein. So, too, accounts of the greater professionalization of Spanish American law, with the multiplication of letrados as judges or as "judicial advisors."

The dominant narratives of change deployed by British American legal historians are more dynamic in that they feature a rupture, or a significant reorientation, of the colonial legal systems between the seventeenth and eighteenth centuries. The most important of these stories is "anglicization." This development has two parts. The first concerns an alteration in dispute resolution and the character of litigation. Few trained lawyers immigrated to seventeenth century America. The colonial court systems were overwhelmingly staffed not by legal professionals but by laymen who administered nontechnical, arbitral, and discretionary justice and brushed aside inconvenient ordinances. Magistrates selected more for their social prominence than their legal competence praised fairness and looked down on legal "niceties." Settlers concentrated on the substance of disputes and dispensed with the intricacies of English legal procedure, with its complicated rules of pleading and obscure terms of art. Community leaders commonly valued arbitration over litigation. By the late seventeenth century, important elements of this inherited system were under stress. The rate of litigation increased faster than population in the eighteenth century. Where neighbors might arbitrate disagreements in order to restore peace in a face-to-face community, population growth and dispersion and the expansion of long-distance trade and credit networks meant that more disputes arose among strangers "at arm's length" determined to prevail at trial even at the cost of fracturing relationships. Commercialization, especially trans-Atlantic trade, created pressures for a more predictable, more lawyerly and formal legal system, one more attentive to English precedents and procedures. As tribunals increasingly respected rather than recoiled from legal technicality, litigants found it in their interest to hire lawyers who dissected pleadings and sought delays and reviews. This further undermined the simplicity and accessibility of colonial justice. The colonial legal system became more like England's, became more "anglicized" as it moved from a "communal, informal mode of resolving disputes to a rationalized, lawyerly," technical mode. ${ }^{22}$

21 Bravo Lira (1989) 11-37; Haring (1963) 69-70; Muro Orejón (1970); Tau (1992b); Zorraquín BeCú (1994) 416.

22 Botein (1981); Dayton (1995); Dayton (1993) 10 [quote in Dayton (1995)]; Hoffer (1998) 76-85, 93-97; Mann (1987); Murrin (1983); Rosen (1992). Although these inter- 
The British colonies "anglicized" in a second way in that their intensely regional legal cultures lost some of their distinctiveness and converged towards the legal order of England. The Puritan commitments of New England, the Quaker experiment in Pennsylvania, the Dutch heritage and the Stuart monarchs' absolutist initiatives in New York, and the Catholic presence in Maryland faded in the eighteenth century, losing their seventeenth century salience. Although marked economic, social and demographic differences continued to divide the regions of eighteenth century British North America, increasing imperial oversight of colonial lawmaking and judicature reduced the distinctiveness of regional legal orders. The king's Privy Council began taking appeals from colonial courts and vetting legislation. Britain appointed English barristers as judges on supreme tribunals and introduced customs inspectors, admiralty judges, and other imperial administrators into the colonies. Through these mechanisms the Empire reconfigured colonial judiciaries along more uniform and hierarchical lines, eliminated the appellate jurisdiction of Assemblies, and suppressed practices that were too puritan, Quaker or Dutch or that interfered with imperial control of trade and the royal prerogative. This partial convergence of regional legal orders was part of a larger North American anglicization noticeable in the formation of a deeper, more self-conscious British identity and the growing resemblance of elite culture and values, military structures, and consumption patterns across the colonies and the metropolis. ${ }^{23}$

Comparing the dynamic transformations captured by the rubric of "anglicization" to the incremental changes of the derecho indiano in the mature Spanish American Empire suggests two (somewhat speculative) hypotheses one brief, and one more extensive. To begin with, might we suppose that the eighteenth-century British colonies not only converged towards each other and towards England but also towards the Spanish Empire by developing certain features of a collective legal order, this hitherto missing analogue to

related processes have been taken as evidence of the "anglicization" of colonial law, important elements of them have also been organized under other rubrics, such as legal "modernization." On the latter, see the debate between Priest (2001), and ManN (2002), and Priest's reply, ibid., 1881-1887.

23 Botein (1983) 50-67; Breen (1984) 221-223; Breen (1986); Greene (1988) 170-177; Murrin (1966). To be sure, regional legal orders only partially converged. On the importance of communications patterns in preserving some measure of diversity among the colonies' legal orders, see Ross (2008). 
the derecho indiano? In eighteenth century British America, institutional forms grew more similar among the regions; the Empire articulated more elaborate choice of law rules for meshing metropolitan legal norms with settler norms, backed up by a more intrusive imperial review of legislation and adjudication and provision for appeals to a crown council; and finally, Britain engaged in more direct regulation of colonial society through parliamentary legislation, gubernatorial instructions, and crown-controlled tribunals such as vice-admiralty courts. These developments are reminiscent of analogous features in the derecho indiano. Perhaps some measure of convergence between the Spanish and British empires occurred in the eighteenth century as elements of a collective legal order emerged that were absent or muted in the regionally distinctive seventeenth century English colonies living under a lax empire. Although no derecho británico indiano existed on the eve of the American Revolution, were there intimations of one ${ }^{24}$

I will develop my second (speculative) hypothesis at greater length. British American anglicization is about the reorientation of a legal order on account of powerful social forces: population growth and dispersal, greater participation in transatlantic trade, and a newly intrusive English Empire. Was there an analogy in the Spanish Empire - a story about the recreation of a legal order under the pressure of profound demographic, political, and economic change? In search of this story, we should look not at the settler side of the derecho indiano (which featured consolidation and incremental change), but at the Indian side. The Spanish Empire famously used law and bureaucracy to regulate the lives of indigenous peoples - to calibrate their tribute and labor requirements, to gather together dispersed Indians through congregaciones, and to develop semi-autonomous governance under Spanish oversight in the republic of the Indios. Within this general framework, there were specific ways in which the changing relationship of the derecho indiano

24 What I am suggesting is related to, but ultimately different than, the convergence of the political cultures of the two empires in the late seventeenth century and early eighteenth century observed by historians. Venality and creolization of officeholding in Spanish America granted settlers a larger degree of self-rule. Meanwhile, the pressures of a more intrusive British Empire encouraged English settlers to learn how to lobby and manipulate an imperial bureaucracy. As a result, the differences in British and Spanish American political culture narrowed. ElLiotr (2006) 378-379. By contrast, I have sketched out really, speculated about - a (partial) convergence in the legal orders of the two empires. 
to indigenous peoples between the mid-sixteenth and mid-eighteenth century brings to mind elements of the anglicization story.

First, "anglicization" refers to the transformation of litigation in the North American colonies, a move towards a more technical, lawyerly, and formal system, one more responsive to English precedents and procedures. Indigenous communities in Spanish America underwent a (partial) Hispanicization in how they handled disputes. As is well known, natives became adept at using Spanish legal tools, from petitions and lawsuits to appeals and amparos, in order to protect communal lands, participate in newly formed private land markets, reduce tribute and labor exactions, defend against the overreaching of officials, and mediate political conflicts. ${ }^{25}$ As Indians grew more knowledgeable about Spanish law, they began to import into their legal affairs and governance of their own communities Spanish procedures and concepts learned in conflicts with settlers and imperial officials. One sees this in land records used within Nahua communities, in conflicts among ethnic groups and Andean ayllus, and in disputes about succession to major chieftainships. Native commoners appealed to Spanish legal concepts and tribunals when fighting to reduce duties owed to Indian notables. Indigenous governadores and alcaldes mixed native usages with Spanish legalisms when they judged other Indians or conducted residencias for Indian officials. $^{26}$ By the end of the seventeenth century, lawyers needed to do less translating of the accounts of indigenous complainants and witnesses into Spanish legal categories as natives became more familiar with legalistic terminology. ${ }^{27}$ To look at these developments comparatively is to notice that indigenous internalization of Spanish legal procedures and concepts, what Tau provocatively calls "mestizaje jurídico," resembles anglicization in certain respects. ${ }^{28}$ For anglicization likewise involved both an external dimension (the deployment of English legal technicalities by settlers disputing with imperial officials) and an internal dimension (the refashioning of settlers' legal culture as they became habituated to more lawyerly and formal English legal procedures and concepts).

25 Kellogg (1995) 13, 51; Owensby (2008) 20, 41-44, 88-89, 95-100, 127-128, 137-140, 157, 295-93; STERN (1993) 116-119.

26 Gibson (1964) 180-181; LockHART (1992) 166-167; STERN (1993) 132-134.

27 Kellogg (1995) 13, 82.

28 TAU (1997) 102.

22 Richard J. Ross 
Second, anglicization alludes to a more "English" style of governance in the colonies. This involved the creation of more hierarchical judiciaries, the elimination of Assembly appellate jurisdiction, and the displacement of some measure of Creole control by the appointment of customs inspectors, vice-admiralty judges, and English barristers in the colonial supreme courts. By the latter seventeenth century, the Crown not only began accepting appeals from colonial supreme courts, but demanded that statutes be sent for vetting, which could lead to editing or abrogation. The Board of Trade sent questionnaires to the colonies asking about their laws and customs, a proactive way of beginning the process of inspection. As Spanish American historians have detailed, over time Castile pressed for a more intrusive governance of indigenous communities. This occurred in stages. From the midsixteenth century onward, the Empire drew on models of Spanish municipal government to impose cabildos with alcaldes and regidores on native community units. ${ }^{29}$ The imperial bureaucracy from the local corregidor through the Council of the Indies scrutinized indigenous customs and bylaws, reserving the right to eliminate native usages that violated natural law, reason, or Christian doctrine. The Empire's screening process did only extend to usages brought before its tribunals. Crown officials interviewed Indian elders and conducted ethnographic and historical surveys in order to determine - and begin the triage of - native customs. ${ }^{30}$ By the latter eighteenth century, in some parts of Spanish America, newly appointed local officials answerable to the Crown intervened more extensively into Indian affairs within native communities. Subdelegates and jueces españoles inserted among the Yucatan Mayans increasingly adjudicated intra-Indian disputes that previously would have been handled by native leaders. ${ }^{31}$ Viewing these developments with an eye on the anglicization of British North American colonial governance reveals some intriguing similarities. In both cases, one sees the (partial) reordering of governing structures along metropolitan lines; a modest shift from indirect to direct rule through the appointment of officials more responsive to imperial priorities than to local audiences; and the vetting of

Gibson (1964) 166-181; Horn (1997) 44-85; LockHART (1992) 28-58.

30 Borah (1983) 43; TAU (2001) 134-143.

31 FARRISs (1984) 355-366. In other areas, such as New Spain, the Bourbon reforms do not appear to have made much difference in the governance of Indian communities. GiBson (1966) 173. 
locally generated customs and bylaws, both reactively (as a byproduct of litigation and appeals) and proactively (through crown-initiated surveys and questionnaires).

Third and finally, anglicization refers to the fading distinctiveness of the legal cultures in the English colonies and the convergence of those legal cultures toward each other and toward England. The strictures of the derecho indiano likewise pushed for a (partial) convergence of the distinct indigenous legal cultures among the Nahuas, the Yucatan Mayas, and the Andean peoples. Over the sixteenth and seventeenth centuries, the wide variety of institutional forms that had previously obtained among indigenous towns and villages in Mexico, the Yucatan, and the Andes were subordinated as the Spanish imposed upon native communities throughout the Americas an administrative structure modeled on Castilian municipal government: the cabildo with its alcaldes, regidores, escrivanos, and other minor officials. Like their Spanish counterparts, Indian officers in all of these regions came to enjoy legal authority - as a formal matter - because of their connection to the king rather than by hereditary succession. Indian hierarchical chains of command reaching downward from the provincial level withered away. ${ }^{32}$ As indigenous governance withdrew from provincial networks to concentrate in cabildos with structural similarities throughout the Americas, as Indian officials traced the source of their power back to the Crown, as native judicature and administration increasingly incorporated Spanish legal concepts and looked upwards to imperial tribunals and councils for appeals and redress of grievances, then the legal cultures of Nahua, Yucatan, and Andean communities began to look more like each other, and somewhat more like Castile, than they had at the time of conquest. At least to some extent, they converged. Let me be clear about what I am not saying: that indigenous communities and the colonies of British North America were socially or legally similar. Instead, more modestly, I claim that there were suggestive parallels in their direction of movement - in the "convergence" that each underwent and in the transformations they experienced in dispute resolution and governance structures. If this is true, might scholars of British American law looking to establish a Spanish American comparative perspec-

32 FARriss (1984) 148-150, 158-159; GibSON (1964) 166-167; Owensby (2008) 37, 212-213, 227.

$24 \quad$ Richard J. Ross 
tive on their dominant narrative of legal "anglicization" be better served by looking to the experience of indigenous peoples than of Castilian settlers?

\section{Bibliography}

Abásolo, Ezequiel (2015), Víctor Tau Anzoátegui en la historiografía jurídica indiana, in: Duve, Thomas / Pinlajamäki, Heikкi (eds.), New Horizons of Spanish Colonial Law: Contributions to Transnational Early Modern Legal History, Frankfurt, 151-159

Altamira, Rafael (1945), Autonomía y Descentralización Legislativa en el Régimen Colonial Español: Legislación Metropolitana y Legislación Propiamente Indiana (Siglos XVI a XVIII)

Borah, Woodrow (1983), Justice by Insurance: The General Indian Court of Colonial Mexico and the Legal Aides of the Half-Real, Berkeley

Botein, Stephen (1980), Religion and Politics in Revolutionary New England: Natural Rights Reconsidered, in: Bonomi, Patricia U. (ed.), Party and Political Opposition in Revolutionary America, Tarrytown, 13-34

Botein, Stephen (1981), The Legal Profession in Colonial North America, in: Prest, WiLfrid (ed.), Lawyers in Early Modern Europe and America, New York, $129-146$

Botein, Stephen (1983), Early American Law and Society, New York

Bilder, Mary Sarah (2004), The Transatlantic Constitution: Colonial Legal Culture and the Empire, Cambridge

Bravo Lira, Bernardino (1989), Derecho común y derecho propio en el Nuevo Mundo, Santiago

Breen, T. H. (1984), Creative Adaptations: Peoples and Cultures, in: Greene, Jack. P./ Pole, J. R. (eds.), Colonial British America: Essays in the New History of the Early Modern Era, Baltimore, 195-232

Breen, T. H. (1986), An Empire of Goods: The Anglicization of Colonial America, 1690-1776, in: Journal of British Studies 25, 467-499

Brown, Elizabeth G. (1964), British Statutes in American Law, 1776-1836, Ann Arbor

Cutter, Charles R. (1995), The Legal Culture of Northern New Spain, 1700-1810, Albuquerque

Dayton, Cornelia Hughes (1993), Turning Points and the Relevance of Colonial Legal History, in: William and Mary Quarterly 50, 7-17

Dayton, Cornelia Hughes (1995), Women before the Bar: Gender, Law, and Society in Connecticut, 1639-1789, Chapel Hill

Dunn, Mary Maples (1967), William Penn: Politics and Conscience, Princeton

Elliott, J. H. (2006), Empires of the Atlantic World: Britain and Spain in America 1492-1830, New Haven 
Farriss, Nancy M. (1984), Maya Society under Colonial Rule: The Collective Enterprise of Survival, Princeton

Fitzmaurice, Andrew (2003), Humanism and America: An Intellectual History of English Colonization, 1500-1625, Cambridge

Gaustad, Edwin S. (1991), Liberty of Conscience: Roger Williams in America, Grand Rapids

Gibson, Charles (1964), The Aztecs under Spanish Rule: A History of the Indians of the Valley of Mexico, 1519-1810, Stanford

Gibson, Charles (1966), Spain in America, New York

González, María Del Refugio (1995), El derecho indiano y el derecho provincial novohispano: marco historiográfico y conceptual, Mexico City

Greene, Jack P. (1987), Peripheries and Center: Constitutional Development in the Extended Polities of the British Empire and the United States, 1607-1788, Athens

Greene, Jack P. (1988), Pursuits of Happiness: The Social Development of Early Modern British Colonies and the Formation of American Culture, Chapel Hill

Greene, Jack P. (2011), The Constitutional Origins of the American Revolution, Cambridge

Haring, Clarence H. (1963), The Spanish Empire in America, New York

Herzog, Tamar (1995), Sobre la Cultura Jurídica en la América Colonial (Siglos XVI-XVIII), in: Anuario de Historia del Derecho Español 65, 903-911

Herzog, Tamar (2003), Defining Nations: Immigrants and Citizens in Early Modern Spain and Spanish America, New Haven

Herzog, Tamar (2004), Upholding Justice: Society, State, and the Penal System in Quito (1650-1750), Ann Arbor

Herzog, Tamar (2015), Did European Law Turn American? Territory, Property and Rights in an Atlantic World, in: Duve, Thomas / Pinlajamäki, Heikк (eds.), New Horizons of Spanish Colonial Law: Contributions to Transnational Early Modern Legal History, Frankfurt, 75-95

Hoffer, Peter Charles (1998), Law and People in Colonial America, Baltimore

Horn, Rebecca (1997), Postconquest Coyoacan: Nahua-Spanish Relations in Central Mexico, 1519-1650, Stanford

Hulsebosch, Daniel J. (1998), Imperia in Imperio: The Multiple Constitutions of Empire in New York, 1750-1777, in: Law and History Review 16, 319-379

Hulsebosch, Daniel J. (2005), Constituting Empire: New York and the Transformation of Constitutionalism in the Atlantic World, 1664-1830, Chapel Hill

Kellogg, Susan (1995), Law and the Transformation of Aztec Culture, 1500-1700, Norman

Konig, David Thomas (2008), Regionalism in Early American Law, in: Grossberg, Michael/ Tomlins, Christopher (eds.), The Cambridge History of Law in America, Volume 1: Early America (1580-1815), Cambridge, 144-177

Lang, James (1975), Conquest and Commerce: Spain and England in the Americas, New York 
Lockhart, James (1992), The Nahuas after the Conquest, Stanford

Mann, Bruce H. (1987), Neighbors and Strangers: Law and Community in Early Connecticut, Chapel Hill

Mann, Bruce H. (2002), Law, Economy and Society in Early New England, in: Yale Law Journal 111, 1869-1880

Miller, Peter N. (1994), Defining the Common Good: Empire, Religion and Philosophy in Eighteenth-Century Britain, Cambridge

Morgan, Edmund S. (1967), Roger Williams: The Church and the State, New York

Mosse, George L. (1957), The Holy Pretense: A Study in Christianity and Reason of State from William Perkins to John Winthrop, Oxford

Muro Orejón, Antonio (1970), Periodificación del Derecho Indiano, in: Revista Chilena de Historia del Derecho 6, 63-67

Murphy, Andrew R. (2001), Conscience and Community: Revisiting Toleration and Religious Dissent in Early Modern England and America, University Park

Murrin, John (1966), Anglicizing an American Colony: The Transformation of Provincial Massachusetts, PhD dissertation, Yale University

Murrin, John (1983), The Legal Transformation: The Bench and Bar of EighteenthCentury Massachusetts, in: Katz, Stanley N./Murrin, John (eds.), Colonial America: Essays in Politics and Social Development, New York, 540-572

Nelson, William E. (2008), The Common Law of Colonial America, Volume I: The Chesapeake and New England 1607-1660, Oxford

Nuzzo, Luigi (2015), Between America and Europe: The strange case of the derecho indiano, in: Duve, Thomas / Pinlajamäкi, Heikкi (eds.), New Horizons of Spanish Colonial Law: Contributions to Transnational Early Modern Legal History, Frankfurt, 161-191

Owensby, Brian (2008), Empire of Law and Indian Justice in Colonial Mexico, Stanford

Owensby, Brian (2015), The Theater of Conscience in the "Living Law" of the Indies, in: Duve, Thomas / Pinlajamäki, Heikкi (eds.), New Horizons of Spanish Colonial Law: Contributions to Transnational Early Modern Legal History, Frankfurt, $125-159$

Pagden, Anthony (1995), Lords of All the World: Ideologies of Empire in Spain, Britain and France, c.1500 - c.1800, New Haven

Pinlajamäki, Heikki (2010), La invención del derecho indiano: las raíces cosmopolitanas de la disciplina, in: Revista chilena de historia del derecho 22, 583-592

Pinlajamäki, Heikкi (2015), The Westernization of Police Regulation: Spanish and British Colonial Laws Compared, in: Duve, Thomas / Pinlajamäki, Нeikкi (eds.), New Horizons of Spanish Colonial Law: Contributions to Transnational Early Modern Legal History, Frankfurt, 97-124

Priest, Claire (2001), Currency Policies and Legal Development in Colonial New England, in: Yale Law Journal 110, 1303-1405

Roeber, G. (2001), What the Law Requires is Written on Their Hearts: Noachic and Natural Law among German-Speakers in Early Modern North America, in: William and Mary Quarterly 58, 883-912 
Rosen, Deborah A. (1992), Courts and Commerce in New York, in: American Journal of Legal History 36, 139-163

Ross, Richard J. (2008), Legal Communications and Imperial Governance: British North America and Spanish America Compared, in: Grossberg, Michael/ Tomlins, Christopher (eds.), The Cambridge History of Law in America, Volume 1: Early America (1580-1815), Cambridge, 104-143

Ross, Richard J. (2012), Distinguishing Eternal from Transient Law: Natural Law and the Judicial Laws of Moses, in: Past and Present 217 (1) 79-115

Smith, Joseph H. (1950), Appeals to the Privy Council from the American Plantations, New York

Smith, Joseph H. (1969), Administrative Control of the Courts of the American Plantations, in: Flaherty, David (ed.), Essays in the History of Early American Law, Chapel Hill, 281-335

Smith, Joseph H. (1970), New Light on the Doctrine of Judicial Precedent in Early America, 1607-1776, in: Hazard, John N./Wagner, Wenceslas J. (eds.), Legal Thought in the United States of America under Contemporary Pressures, Brussels, 9-39

Solórzano Pereira, Juan de (1996 [1648]), Política Indiana, I, Madrid

Stern, Steve J. (1993), Peru's Indian Peoples and the Challenge of Spanish Conquest: Huamanga to 1640,2 nd ed., Madison

TAu Anzoátegui, Víctor (1992a), La Ley en América Hispana: Del Descubrimiento a la Emancipación, Buenos Aires

Tau Anzoátegui, Víctor (1992b), Casuismo y Sistema: Indagación Histórica sobre el Espíritu del Derecho Indiano, Buenos Aires

Tau Anzoátegui, Víctor (1997), Nuevos Horizontes en el Estudio Historico del Derecho Indiano, Buenos Aires

TAu Anzoátegui, Víctor (2001), El poder de la costumbre: Estudios sobre el derecho consuetudinario en América hispana hasta la emancipación, Buenos Aires

Tau Anzoátegui, Víctor (2002), La disimulación en el Derecho Indiano, in: Barrios Pintado, Feliciano (ed.), Derecho y administración pública en las Indias hispánicas: Actas del XII Congreso Internacional de Historia del Derecho Indiano, Cuenca, II, 1733-1752

Tomlins, Christopher (2010), Freedom Bound: Law, Labor, and Civic Identity in Colonizing English America, 1580-1865, Cambridge

Wright, Benjamin F. (1931), American Interpretations of Natural Law: A Study in the History of Political Thought, Cambridge

Yirush, Craig (2011), Settlers, Liberty, and Empire: The Roots of Early American Political Theory, 1675-1775, Cambridge

Zorraquín Becú, Ricardo (1994), Hacia una Definición del Derecho Indiano, in: Revista de Historia del Derecho 22, 401-417 
Rafael D. García Pérez

\section{Revisiting the America's Colonial Status under the Spanish Monarchy}

Most historians focused on the Americas have assumed the colonial status of Spanish America. With some exceptions, which will be mentioned throughout this paper, the period between the conquest and independence of Spanish America is described as "colonial" and, thus, included in the long-term history of the phenomenon of colonialism in the world. ${ }^{1}$ Within this common framework, there are different interpretations of the nature of this colonial relationship, its degree of continuity with 19th-Century colonial experiences, or the relatively typical character of colonial societies in the Americas between the 16th and 18th Centuries. This is not the place to reconstruct the genealogy of this interpretation of colonial Spanish America, even though there is no doubt about the role that post-colonial discourse has had and continues to have in its consolidation. ${ }^{2}$ In post-colonial discourse, the colonial nature is a heuristic tool in the hands of historians, a starting point for a historical study ultimately conceived as the deconstruction of discourses that mask and reproduce dynamics of power and control between European powers and colonized countries. ${ }^{3}$

The starting point in this paper is different. The colonial nature of the relationship between the so-called West Indies and the Crown of Castile is the subject of study, rather than an assumption. Our purpose is to try to offer, from legal history, a new reading of Spanish colonialism that could lead to a more accurate interpretation of Latin American history. To this end, it is worth reflecting on the historiographical categories we are using to define the "political" status of American territories under the Spanish

1 A typical example of the assumption of this "colonial paradigm" is the title of the welldocumented work by Woseber (2003). The author does not explain why she uses the phrase "Colonial Domination" as the title for her work. Its appropriateness is taken for granted.

2 For the formation of post-colonialism and its different projections, see Young (2001).

3 In this sense the question is revisited. Mabel Moraña/Jáuregui (2008). 
Monarchy and particularly on the preunderstandings and explanatory consequences of the "colonial" interpretation of this historical period.

We will begin by critically rebuilding the debate on the political status of the Indies which Ricardo Levene started in Argentina in 1951 (I). We will deal with the major contributions to the subject, and we will focus on the theses supported by another Argentine in the 1970s, Ricardo Zorraquín Becú, and on the debate on the subject published in the journal Nuevo Mundo, Mundos Nuevos in 2004. Next, we will discuss the place occupied by the Indies under the Spanish Monarchy from a diachronic perspective that addresses the changes that both Spanish America and the Court underwent during the Modern Age (II). Finally, we will conclude with some thoughts that hopefully will help shed some light on this historiographical debate (III).

\section{From Las Indias no eran Colonias [The Indies were not Colonies] to the Livre noir du colonialisme [The Black Book of Colonialism]}

\section{Levene's proposal: Las Indias no eran Colonias}

Sixty years have elapsed since Ricardo Levene contested the treatment of colonies which historiography gave - and continues to give - to the Spanish dominions in the Americas during the Modern Age. ${ }^{4}$ The publication of the Argentine historian's theses, condensed into the title of his work Las Indias no eran Colonias, gave end to a series of actions promoted by Levene that were favorably received by the Argentine National Academy of History for the first time in 1948. Their aim was to replace the term "colonial" with other terms that evidence the full integration of Spanish America into the Spanish Monarchy as "provinces, kingdoms, dominions, republics (the latter term, in the etymological sense)." ${ }^{5}$ Levene's work addressed the problem

4 LeVEne (1951).

5 Levene (1951) 10. On 2 October 1948, the Argentine National Academy of History debated the proposal put forward by its president whereby he "suggested that the authors of works of research, abstracts or texts on history of the Americas and of Argentina, substitute the expression 'colonial period' for 'period of Spanish rule and civilization,"' among others. Finally, the proposal was accepted, with Ravignani's dissenting opinion, although the expression 'Hispanic period' was favored to the one originally put forward. The minutes are transcribed at the end of Levene (1951) 153-156. 
from a strong legal positivist perspective. In his argument, the Argentine historian attached special significance to the laws promulgated by Castilian Monarchs, in particular to the Recopilación de Leyes de Indias [Compilation of the Law of the Indies]. ${ }^{6}$

These Argentine pronouncements were echoed in Spain immediately. ${ }^{7}$ In 1949, the First Hispanic-American Conference on History agreed to name the colonial period "period of Spanish rule." In 1954, the Instituto Gonzalo Fernández de Oviedo, affiliated to the Consejo Superior de Investigaciones Cientificas [Higher Council for Scientific Research], organized two work sessions for its members to discuss the issue. The conclusions they reached were somewhat more nuanced than those approved by the Argentine Academy, but both institutions strongly concurred in matters of substance. According to the Institute, the terms used by the Law of the Indies and by "Spanish Constitutional law" to refer to the Spanish American territories had been "kingdoms," "domains" or "provinces," equating them to peninsu-

6 Summarizing the arguments that he would develop throughout the book, Levene stated in the preliminary chapter that "The Indies were not colonies, according to express legal provisions, because they were incorporated into the Crown of Castile and Leon, according to Pontifical concession and to the inspirations of the Catholic Monarchs, and they could not be disposed of; because their natives were on a legal par with European Spaniards and the legitimacy of marriage between them was consecrated; because the descendants of European or Creole Spaniards, and in general the worthy of the Indies, had preferential allocation of offices; because the Councils of Castile and of the Indies shared the same high political powers; because the provincial or regional institutions of the Indies exercised legislative authority; because the kingdoms of Castile and Leon and of the Indies belonged to one Crown, and their laws and order of Government had to be as similar as possible; because in all the cases where it was not decided what the laws of the Indies should provide for, those of Castile would be observed according to the order of precedence of the Leyes de Toro [Laws of Toro]; because, finally, the term conquest as source of law was removed, and it was replaced by the terms population and pacification." Levene (1951) 10-11.

7 It should be remembered, however, that in 1946 legal historian Alfonso García Gallo had published a lecture on "The political constitution of the Spanish Indies," where he stated that legally the Indies constituted a "political entity with independent personality." Yet, this did not mean denying their special bond with Castile to the extent that such close bond - as García Gallo pointed out - "sometimes becomes a true merger and the title of Kingdoms of the Indies has only an honorific value, such as that of the Kingdoms of León, Toledo, Granada, etc., merged into the Crown of Castile.' In addition, he rejected the term colonies to refer to the Indies, recalling that the laws referred to them as kingdoms, provinces or, in the 18th Century, domains. García Gallo (1946) 16-17. 
lar terms. Therefore, expressions such as "colonialism," "colonialist", "colonist" and "coloniage," deemed harmful to the dignity of those peoples, could not be used to refer to the relationships between both worlds. There was no such problem, however, with the terms "colony," "colonization," "colonizer" and "colonial," as long as they were used in their technical sense. ${ }^{8}$ In this regard, the Institute was adamant to clearly state the differences between the Spanish colonization and modern colonialism, which is why it stated that, since the latter had "distorted the pristine meaning" of the above-mentioned terms "colony" or "colonization," they should be used where it was not possible to employ other expressions conveying more limited meaning, such as "period of Spanish rule," "Spanish period," "Hispanic," "Viceregal," "PreViceregal," "Proto-Viceregal" periods, etc. Finally, considering the overall picture of colonization, the Institute stressed the need to highlight the Spanish one due to "the high spiritual and human values that characterized it."'

It is inappropriate to provide here a detailed description of the first moment of historiographical discussion brought about by Levene's initiative and its continuation until the mid-1970s, since this has already been duly reconstructed by Tau Anzoátegui. ${ }^{10}$ However, it is relevant to highlight the

8 As stated in the minutes of the sessions, designating the Spanish American territories as kingdoms, provinces or domains in the legal sources did not entail any obstacle for the Institute "to place the Spanish action in the Indies within the multiple colonization processes that have taken place throughout the history of mankind, though, as stated above, valuing its uniqueness, and not diminishing the greatness of the 'Spanish colonization' period for receiving such designation nor considering it harmful for those States that owe the base of their current existence as nations to the referred period." Acerca del término "colonia" (1954) 176.

9 Acerca del término "colonia" (1954) 180. The conclusions of the first session included the assertion that Spain had conducted "a colonization process" in the Americas but it had "not subjected the Spanish American regions under its rule to a regime of exploitation; rather, it gave them a legal personality, and in such legal order the absence of the term colony is evident." Ibid., 159.

10 Tau Anzoátegui (2000) 80-92. As stated by Tau, there was active participation in the debate by the most prominent specialists of the time - with different political views -, such as Ots Capdequí, Rafael Altamira, Alfonso García Gallo, Mario Góngora, Richard Konetzke or Demetrio Ramos. Even though there was general consensus with the theses supported by the Argentine Academy, there were also dissenting voices. Altamira believed it was correct to speak of colonies, in the classical sense of the term, as a result of the action of populating, even if the territories were denominated provinces, dominions or kingdoms. Ots shared Levene's proposals, although he rejected equality between Peninsu- 
terms in which the debate was held as well as its ideological background because, despite the time elapsed since then, some of these features still describe the treatment of this issue.

The debate about whether it was appropriate to use the word "colony" was not understood then in purely nominal terms. Implicitly, and sometimes also explicitly, for many participants the subject of debate was not so much the place occupied by the Spanish American territories under the Spanish Monarchy but the role played by "Spain" in the Americas. The result of such dispute, which seems related to the one involving other actors in the 18th Century, ${ }^{11}$ appeared fraught with political consequences on both sides of the Atlantic. What was at stake in Argentina and in other countries in the Americas was the prominent role that the Hispanic world should play in defining the Nations in the Americas. Levene recognized this clearly in the preface to his work of 1951 by stating that the "history of the Americas begins with that of Spain, our spiritual ascent and whose roots connect us with the remote origins of civilization." ${ }^{12}$ In this regard, the Argentine historian not only excluded from such historical past indigenous cultures, alien to that historical context through which the Americas connected with "civilization" (which could only be European), but also linked the debate about the nature of colonial Spanish domination directly to their present, because ultimately the Americas had their spiritual origin and roots in Spain.

Therefore, it was not a terminological problem. The attempt to remove the term "colonies" from historical vocabulary did not respond to mere academic reasons. In the words of Levene himself, "It is not a mere question of logomachy or discussion where attention is focused solely on the word rather than on the issue itself. [...]. It is about providing evidence, as it is done in this book of historical synthesis, of the legal and political values of Spanish rule - surely not viewed through the glow of the red legend rather

lar and Spanish American inhabitants, without this implying any present political statements. According to Mario Góngora, it was right to use the term colonial when one meant transferring a population nucleus to another territory. However, the relevance of its economic sense required further research. Ibid.

11 It is no coincidence that the "colonial issue" was raised precisely in the 18th Century, in an intellectual context marked by European Enlightenment conceptions of Spanish America and their Creole response. See Gerbi (1973); and CañIzares-Esguerra (2001).

LEVENE (1951) 9. 
than the black one -, values that provide the foundation for the thesis that the Indies were not colonies." ${ }^{13}$

In Spain, the debate was also framed in terms of approval or condemnation of the work done in the Americas. Those were the early years of the Francoist State. The political context favored a nationalist reading of the history of the conquest and incorporation of the Indies into the Spanish Monarchy. ${ }^{14}$ However, this did not lead - as we have seen - to the outright condemnation of the term "colony." From an analysis of the different meanings that the term had received throughout history, it seemed reasonable to conclude that it could be used to designate the Spanish American territories provided it was not used pejoratively, i.e., identifying it with the mere economic exploitation of the New World. ${ }^{15}$ Hence, it can be stated that the debate started by Levene was basically about the historical and cultural identity of Spanish American Nations and, at the same time, about the historical action of Spain in the Indies. In this sense, the starting point was patriotic essentialism: in Francoist Spain, in the most radical nationalist terms, even though (or perhaps because of it) what they tried to defend was the Old Empire; in Argentina, it was the defense of a Hispanic identity.

On the other hand, though the participants in this first debate were historians, in most cases the approach suffered from a certain lack of attention both to the historicity of the issue raised, as to the proper subject of study. In this regard, the image portrayed of the territorial status of the Indies under the Spanish Monarchy quite resembled a static photo whose detailed observation might resolve the issues raised. Thus, unconsciously, not only was the evolution of the relationship between the Crown and its dominions in the Americas over time dispensed with, but also the historicity of "both subjects." Spain and the Americas were presented as compact entities with little historical evolution from the 16th to the 18th Century. Accordingly, also the relations between them and their projection in the status of the

13 Levene (1951) 10.

14 However, such nationalist reading of the Americas' history did not start with the new Francoist regime; rather, it was common to political and academic elites of every political party since the late 19th Century. Feros (2005).

15 Acerca del término "colonia" (1954). The only dissenting opinion appearing on a summary of the debates was that of the Ukrainian historian Juan Friede, who defended the existence of a "colonization phenomenon," understood also as "material exploitation of the indigenous people by the civilizing people." Ibid., 158. 
Indies, whether colonial or not, had to be unique and constant during these three Centuries, which in no way prevented a detailed and precise exposition of the development of the Law of the Indies over time or of the institutional apparatus set up for their government. The "timelessness" of the adopted perspective influenced a deeper level, that of the assumptions underpinning the whole discourse.

Thirdly, it is noteworthy that this academic debate had little significance in both Anglo-Saxon and Latin historiographical production, despite the implications of its proposals. Indeed, it did not lead to the elimination of the concept of colony. At best, it hardly raised awareness of the semantic density of the concept and of the implications of using the term uncritically.

\section{Zorraquín Becú's contribution}

With the emergence of economic history in the analysis of Spanish American reality, brought about by the Annales School, the word "colony" was undisputedly placed at the heart of studies on Spanish America. The debate initiated by Levene was largely set aside. From an economic standpoint, the binomial metropolis-colony offered an interpretive framework that was taken for granted. ${ }^{\mathbf{1 6}}$ In the few cases where this was noted, it was to confirm, without any reservation, the relevance of this framework of "colonial" understanding. ${ }^{\mathbf{1 7}}$

Zorraquín Becú made his contribution to the debate in this new historiographical context. He believed that the problem of the "constitutional status" of the New World under the Spanish Monarchy was the most important problem of the Law of the Indies. However, not many authors had looked at

16 Tau Anzoátegui (2000) 90-91. Tau provides Ruggiero Romano's position as a paradigmatic example, since the latter referred to the term colony and the resulting colonial dependence as a "fact of general economy." Ibid., 91.

17 Tandeter reopened the debate in economic history, not to refute the colonial assumption of these studies but to evidence the lack of theoretical characterization of colonial dependency for the 16th, 17th and 18th Centuries. The fact that this was a purely colonial relationship was unquestionable. Moreover, Tandeter believed that the debate on the colonial nature of the Indies was a mere continuation of the work of Hispanophile historians trying to offer a positive global view of Spain's action in the Americas. According to this author, "Thus develops the pernicious polemic that denies the nature of colonies to the Indies under the Spanish rule." TANDETER (1976) 156. 
it or, at least, not in depth. ${ }^{18}$ Spurred by this conviction, Zorraquín presented a paper on this topic at the Second Venezuelan Conference of History, held in Caracas in 1974, which was published in the collected papers of the Conference ${ }^{19}$ and in the journal Revista de Historia del Derecho. ${ }^{20}$ Subsequently, he included it in his Estudios de Historia del Derecho. ${ }^{\mathbf{2 1}}$

According to Zorraquín, the question of the political status of the Indies should be answered by resorting to "facts and laws", and not to the theories of those who took part in the controversies over the Indies in the 16th Century or to modern views. Thus, from the very beginning, he established the limits within which he would analyze the problem. This did not prevent him, however, from carrying out well-documented work with interpretation proposals which are largely valid today.

The specific issues he intended to resolve were the political status of the Indies in the Monarchy, the nature of their incorporation to Castile and the institutional consequences that followed. ${ }^{22}$ With this aim in view, Zorraquín organized his work into four parts, each corresponding to a specific historical period: The first part dealt with the Indies as dominions of the Catholic Monarchs, and covered the period between their discovery and the death of Ferdinand the Catholic (pages 61-79); the second part, entitled "the Indies as decentralized provinces of Castile," covered from the incorporation of the Indies to the establishment of the Bourbon dynasty (pages 80-133); the third part, "The progressive centralization of the Monarchy", finished with the abdication of Bayonne and the entry of Napoleonic troops into the Peninsula (pages 134-143); and the fourth part focused on the crisis of the Monarchy (pages 144-161).

As already established by historiography, Zorraquín verified that the Indies had been joined to Castile in the form of an accessory union. In practice, this meant political, legal and economic dependence on the Kingdom of Castile. ${ }^{23}$ Thus, there was no equal footing with Castile or integra-

18 Zorraquín Becú (1988) 55.

19 Zorraquín Becú (1975).

20 Zorraquín Becú (1974).

21 Zorraquín Becú (1988) 55-161.

22 Ibid. 59-60.

23 Zorraquín summarized the dependence of the Indies on the Kingdom of Castile in eight points: They could not decide on the election, recognition or acceptance of the King; they did not have their own Courts as other kingdoms of the Monarchy; they were not in- 
tion into the Spanish Monarchy comparable to that of other kingdoms. Spanish America was subordinated to European politics and not vice versa. Nevertheless, Zorraquín believed that the Indies could not be considered colonies for two main reasons: Firstly, because Spanish American territories were not deprived of their own government and, in addition, a special law was created for them; secondly, because the term "colonies", understood as "mere dependencies exploited by another State", was anachronistic with regard to the New World. The meaning given to this term, therefore, was the Roman Classical and, as such, it rarely appeared in the laws of the Indies. On account of the foregoing, Zorraquín considered that the Indies were in an intermediate situation: they were not totally subordinate to Castile, nor did they enjoy perfect autonomy, comparable to that of the kingdoms joined to the Spanish Monarchy. In the absence of a categorization in the language of pre-modern times, Zorraquín spoke of "decentralized entities of the Castilian administration," in the understanding that it was a territorial and selfregulating decentralization due to the high degree of self-government they attained, despite imposed centralism on the government by the Council of the Indies. To sum up his position, he wrote that "there was self-regulation in the region as a whole with regard to Castile, centralism imposed by the Council on the New World, and decentralization if the existence of each of the major regions into which the Indies were divided was taken into account." ${ }^{24}$

It follows from the paragraph titles of the Laws of 1681, that the Indies had developed from dominions to acquire the legal status of provinces. Zorraquín formulated his interpretation on the latter concept - deeply rooted in history - emphasizing the contrast between the autonomy achieved by the Spanish American provinces during the 16th and 17th Centuries and the process of "centralization" imposed on them since the

volved in the government of the whole of the Monarchy nor were they incorporated into the common organs of the Empire; decisions regarding international treaties and wars, even if affecting the Americas, were made in Europe; the most significant decisions concerning the Law of the Indies were taken without participation of residents or local authorities; both the King and the most important organs of government of the Indies were located in Castile and were subject to Castilian influence; senior officers, both in the Court and in Spanish America were of peninsular origin; and finally, there was trade monopoly with Castile. Zorraquín Becú (1988) 106.

Zorraquín Becú (1988) 107-113. 
18th Century. This policy ended with the crisis of the Monarchy and the creation of the new Nations after their independence. Hence, Zorraquín's interpretation seemed to emphasize, without saying so expressly, the tensions that the contemplation of the government system of the Indies as a whole revealed. On the one hand, he noted a clear dependence on Castile together with the existence of some territories vested with a certain political and legal personality. On the other hand, he spoke of centralization being apparent in judicial and governmental institutions in the Court, particularly the Council, along with undeniable autonomy of operation in Spanish America.

In my opinion, one of Zorraquín's greatest achievements was to perceive these contrasts. To this we must add, as Tau has pointed out, the adoption of a dynamic perspective materialized in the division into four historical periods and - following Demetrio Ramos on this - ${ }^{25}$ the relevance given to the term "Province" as the historically most appropriate term to refer to the Spanish American territories. ${ }^{\mathbf{2 6}}$

However, and without detracting from Zorraquín's work of historical clarification, his use of Public Law categories coined in the 19th Century for the construction of the modern liberal state, such as centralization or decentralization, led to the concealment of key dimensions of the political structuring of the Indies under the Spanish Monarchy. Unconsciously, Zorraquín's conception of power was essentially vertical, statist and monolithic, fundamentally alien to the legal culture that governed the formation and development of the Old Regime Monarchies. In this regard, but with more elegance, Tau has said that "using modern notions, conceived by political theory for the contemporary State, to refer to the past [...] entails accepting the idea that the State - in this case the Monarchy - is created and organized top down projecting fundamental rules and actions on all levels, even the smallest and most remote." ${ }^{27}$ Therefore, Tau understands that this vision must be completed with one that assumes Spanish American diversity derived from geographical, temporal or spatial situation, and the existence of "a plurality of small powers and jurisdictions that operate outside the

25 See Ramos Pérez (1959) 36-39. For this author, the term "Province" in its fundamental meaning, connected with Roman tradition and post-independence history, could be applied to the whole Monarchy, all kingdoms being provinces at the same time.

26 Tau Anzoátegui (2000) 97, 101-102 and 120.

27 Ibid. 113. 
central government." ${ }^{28}$ In the Americas, it was essentially on these "small powers and jurisdictions" that the government system was articulated, so this perspective ought to be the starting point of any interpretation seeking to explain the place occupied by the Indies under the Spanish Monarchy to reconstruct, bottom up, the political order in the Indies as well.

\section{Le livre noir du colonialisme [The Black Book of Colonialism] and the reopening of the debate}

The online journal Nuevo Mundo, Mundos Nuevos took advantage of the publication of The Black Book of Colonialism by Marc Ferro in 2003 to reopen the debate on the colonial issue in Latin America. ${ }^{29}$ Rather than "reopening a debate", it would be more appropriate to say opening a new one, since, except for Garavaglia, none of the participants echoed the various viewpoints put forward by legal historiography since the 1950s. And, even in the case of Garavaglia, the reference was aimed exclusively at Levene, and his tone was rather light and contemptuous.

Nonetheless, the debate was not totally alien to the legal historical perspective, even though other approaches prevailed, closer to the new political history or to economic history. Of particular relevance was the participation of Annick Lempérière ${ }^{30}$ in this debate and the responses that her work prompted from Carmen Bernand and Juan Carlos Garavaglia.

The question Lempérière asked, and which guided her reflection, was about the ability of the terms "colony" and "colonial" to adequately describe any phenomenon regarding the Spanish dominions in the Americas between the 16th and 19th Centuries. As this historian pointed out, this practice - introduced by exponents of European Enlightenment such as Raynal or Robertson - was broadly welcome in the independence speech. It was used to reject en masse the period of ownership by the Spanish Crown

28 Tau Anzoátegui (2000) 113.

29 "Para seguir con el debate en torno al colonialismo ...," Nuevo Mundo Mundos Nuevos, Debates (2004), http://nuevomundo.revues.org/430, posted 08/02/2005. Participants in the debate as follows: Sallmann (2004); Subrahmanyam (2004); Lempérière (2004a); BerNand (2004); Gordillo (2004); Garavaglia (2004).

30 A corrected version of this paper was later published under the title El paradigma colonial en la historiografía latinoamericanista: LEMPÉRIÈRE (2004b). Quotations correspond to this version. 
and to lay the ideological foundations of the new Nations. Thus, Creole patriots, once vassals, now became colonized, and the term colony acquired a negative connotation. This tradition of thought joined the anti-colonial critique of the last third of the 19th Century, which brought about a reinterpretation of the period of Spanish rule in the Americas as "first modern imperialism" or caused such period to be set as the starting point of "European colonialism."

Lempérière believes it is necessary to reconvey the historical sense of concepts in order to avoid anachronistic readings of the past, particularly of the so-called Old Regime societies. From her perspective, it is inappropriate to use the term colonization in a sense other than the traditional onedevoid of negative connotation - when referring to any time prior to the 19th Century. The French historian stresses the need for conceptualizing this period of American history by taking into account the space and time coordinates of the creation of these new political communities. Thus, and based on the social or sociological aspect of the "Kingdoms" of the Indies, it is Lempérière's belief that it is possible to resolve the dilemma posed by Levene between colonies and kingdoms. For such purpose, it is convenient to interpret from a historical perspective - that is, one open to changes and mutations - a number of concepts from the domain of sociology, such as "reproduction," "integration" or "social control" ${ }^{31}$ Further on, we will return to this author's proposals since her thoughts may help us reconsider this debate from new viewpoints.

The thesis Lempérière defended was answered directly by Carmen Bernand and, indirectly, without reference to it, by Juan Carlos Garavaglia. Bernand, who shares Lempérière's concern to avoid explanations outside their historical context, believes that the terms "colonialism" and "imperialism," nonetheless, refer to models that are useful to understand Spain's policy in the New World. To that end, Bernand uses "minimalist" definitions as a starting point so that the terms "empire" and "imperialism" as well as "colonial" or "colonialism" become ideal concepts whose variations may be applied to different historical periods. According to the Quillet-Flammarion dictionary, "imperialism" means "politique par laquelle un grand Etat cherche à étendre sa domination;" following the model described by Georges Balandier

31 LeMPÉRIÈre (2004b) 107-120. 
in 1955, "colonization" is "the imposition of an external power over subjected populations." ${ }^{32}$ In Bernand's opinion, both models may be perfectly applied to the Iberian expansion into the New World, without prejudice to specific characteristics of each particular case. ${ }^{33}$

From another perspective, Garavaglia also maintains the existence of a "colonial relationship" in the Americas during the Centuries of Spanish rule, both from the economic and political points of view. On the economic front, Garavaglia studied the constant economic flows from the colonies to the metropolis and the hard- labor jobs implemented to extract riches for the Crown throughout the 16th, 17th and 18th Centuries. On the political front, the Argentine historian highlights the contrast between the rights the King could have in territories such as Naples or Aragon - of a dynastic nature and with limited exercise due to the existence of certain institutions and pre-existent rights - from those he enjoyed in Spanish America as a result of the conquest of non-Christian peoples. This is why, Garaviglia states, it was possible to impose certain rights on Spanish America that would have been unthinkable to impose on other territories owned by the Monarchy. In this unequal context, any negotiation - in the cases where there was one seemed conditioned by power politics. Not even the feeling of white Spanish American elites nurtured by the sense of belonging to the great Spanish Nation in the 18th Century could evolve from mere feeling, and, as such, was unable to deny the existence of a historical relationship of colonial subordination between the Americas and Spain. The Cadiz Parliament, with their mechanism for calling elections and their debate on the political rights of castes, evidenced once again that equality between both sides of the Atlantic was a chimera. ${ }^{34}$

32 A similarly broad concept of the term "colonial", although not expressly defined, is the one employed, for example, by Benton (2002).

33 Bernand (2004). We cannot stop to consider the thorough development of the arguments put forward by Bernand, for which reason we refer the reader to the original text, and the same stands for Lempérière's work and for all the other papers we analyze herein. In her paper published in the Black Book of Colonialism, Bernand had argued that even though both the imposition of tributes on the indigenous peoples as well as the transfer of a substantial portion of Brazil and Spanish America's wealth to the Iberian Peninsula were clear signs of colonial domination, Peru and New Spain were not colonies themselves, but kingdoms joined to the Crown, just as Naples or Navarra. Bernand (2003) 138.

34 Garavaglia (2004). 
4. Some conclusions from an endless debate

Levene published his thought-provoking book sixty years ago. We have focused our attention on some of the most relevant contributions to this debate published since then, but there have been other important reflections on this issue. In this regard, the proposal to distinguish (though up to what extent is still under discussion) Old Regime colonizations ${ }^{35}$ from those carried out by European powers throughout the 19th and 20th Centuries should be highlighted.

Among legal historians, there is agreement on the accessory nature of the union between the Indies and the Kingdom of Castile and, accordingly, on their legal status as territories belonging to the referred Crown. Based on this assumption, Garriga states that "the question about the political status of the Indies $[\ldots]$ can only be answered [...] by maintaining that the Indies had no political status per se." Thus, he tries only to make it clear that, as territories added to the Crown of Castile under an accessory union, they lacked a political constitution of their own, different from the Castilian one, at the heart

of the plural Catholic Monarchy. ${ }^{36}$ In this sense, the colonization of the New World was but a replication of the Castilian legal regime in the Americas. The new lands were regarded as empty spaces (though it was obvious they were not) ready to be legally completed after the Castilian model. ${ }^{37}$

It would be proper, however, to consider the ability of the legal categories of the time and, in particular, the description of the union as accessory, to adequately assess the relationship between Spanish America and Castile and, ultimately, to define the place the former occupied in the Spanish Monarchy. This question, as we will maintain hereinbelow, could help rethink the controversial issue of the legal status of the Indies.

35 The expression references a paper by Poloni-Simard (2003).

36 Garriga Acosta (2006).

37 Part of Garriga's article is focused on the description of this replication of Castile in the Indies after the territorialization of the new lands, that is, their conversion into spaces endowed with jurisdiction. 


\section{An attempt to offer a new reflection on an old question}

The first step in renewing a discussion with such opposing positions could be to assert its eminently historiographical nature and, therefore, continue the debate in academia rather than politics, or any other area characterized by ideological struggle. Ever since Levene's explicit formulation, the debate on the political status of the Indies has been followed, in most cases, by an implicit value judgment on the legitimacy and fairness of Spanish action in the Americas.

Denying the colonial nature of Spanish American territories seemed to involve certain approval of, or at least justification for - given the historical context -, the abuse of indigenous peoples by the Spaniards. Definitely, it is utopian (and likely undesirable) to write history deprived of value judgments. However, that does not mean that we can replace historical analysis with ethical judgment or assert the impossibility to distinguish between both areas. In other words, and regarding this issue, it should be possible to deny the colonial nature of Spanish American territories for the sake of a more accurate interpretation in historiographical terms, and in turn recognize, through such historical interpretation, the manifold abuses of native American peoples by Castilians, or Spaniards in general, whether European or Spanish American, as already distinguished in the 18th Century. And vice versa. Thus, the discussion would be relieved of its strong axiological burden and would facilitate readings with greater appeal to experts in the field.

Having explained the epistemological scope of our study, we should now rephrase it in positive terms. Some of the questions could be: Is it historiographically correct to speak of "colonies" and "colonial relationship" in reference to the lands of the New World and their relation with the Castilian Crown between the late 15th Century and the first third of the 19th Century? To what extent was describing the union as accessory useful to classify the relationship between Spanish America and Castile properly? How did this accessory union evolve between the 16th and 18th Centuries?

This issue - as raised - reminds us of another great historical debate in the past decades: the one on the rise of the modern State. Now, as then, we could attempt to solve it in several ways. One of them is to begin by defining the concept under discussion ("colonies", "State") as broadly as possible so that it may be applied to the period concerned. This is the option chosen by Benard. It was also the view of most of the historiography focused on the 
study of the modern State. According to Jellinek, its definition was based on three core elements: a supreme power, a territory and a population. ${ }^{38}$ In such broad terms, the "State" formula was applicable to political formations as heterogeneous as Monarchies in the late Middle Ages, the "absolute" Monarchies of the Modern Age, and the liberal States of the 19th Century. This even led to a heated discussion in Spain on the potential existence of a Visigoth State. ${ }^{39}$

The main problem of such an approach is the lack or loss of semantic density of key concepts of political and legal history. Formulating in very broad terms concepts which are key to our understanding of history, such as "State" or - in our case - "colony", will severely impair their interpretative potentiality in the long run. Therefore, it is not surprising that they are eventually replaced with other concepts which allow for a more accurate explanation from a historiographical viewpoint.

Another problem of such a discursive strategy is the distortion of the process of historical understanding, which may be caused by the heavy semantic burden acquired by those key concepts in contemporary culture. ${ }^{40}$ Indeed, it is just a possibility since, as certain historiography has proven, one may discuss the State under the Old Regime without it getting tainted with contemporary implications, that is, without slipping in anachronisms by projecting into the past categories and ways of thinking that did not exist at that time. ${ }^{41}$

From that point of view, the question Lempérière asked at the beginning of her article on the colonial paradigm makes sense: "Do the terms 'colony' and 'colonial' account for Hispanic-American history from the 16th Century to their independence and up to the present?" ${ }^{\mathbf{4 2}}$ We should add two further issues: What implicit contents fall within the "colony" and "colonial" categories? Are those contents consistent with the place occupied by the Indies under the Spanish Monarchy, with the political system established there after

38 JellineK (1943).

39 Torres López (1926).

40 A good critical explanation of the discussion about the so-called "modern State," in: Garriga Acosta (2004) 1-5.

41 I am referring to the work by Paolo Grossi and the Florentine school of legal historians. In this area, the works that stand out, among others, are those by Pietro Costa, Maurizio Fioravanti, Lucca Mannori and Bernardo Sordi.

42 LeMpérière (2004b) 107. 
the conquest, and with the type of relationships maintained between the Indies, Castile and the other territories of the Monarchy?

I believe these are the questions that should be asked. It is outside the scope of this paper to answer each of them in detail, as that would mean analyzing from different perspectives the categories at issue - "colony" and "colonial" - and the vast historiography published on the subject during the past decades. However, we should bring forward some resolution proposals that shed new light on this old discussion. Therefore, it is convenient to review the process of integration of the Indies into the Spanish Monarchy during the 16th and 17th Centuries, and the consequences of the establishment of a new dynasty at the beginning of the 18th Century for both the Americas and the other territories of the formerly universal Monarchy. In short, this is about defining the scope of the accessory nature of the union with Castile during these Centuries; the historical evolution of its "contents."

\section{The Indies and the House of Austria}

It is commonplace in historiography to identify the rise of the Bourbon dynasty to the Spanish throne at the turn of the 18th Century as a substantial change in the conception of the Monarchy. During the 16th and 17th Centuries, the Spanish universal Monarchy had been a model of composite and plural Monarchy - the throne being occupied by kings of the House of Austria - where every kingdom maintained its original rights and liberties. The Indies, a territory conquered and incorporated into the Crown of Castile in the form of an accessory union, was an "essential" ${ }^{33}$ part of this conglomerate of kingdoms and crowns united in the public person of the Monarch. Papal Bulls granted dominion over the Indies to the Catholic Monarchs and their "heirs and successors, the Kings of Castile and Leon." ${ }_{4}^{4}$

43 As can be read in the Recopilación de leyes de Indias, Charles V had sworn in 1519 that the Indies "would always remain united, and for their greater perpetuity and strength, we prohibit the disposal thereof. And we order that at no time shall they be separated from the Royal Crown of Castile, disunited or divided, in whole or in part, nor shall their cities, villages, or populations for any reason whatsoever, in favor of any person." He declared null and void any such disposal made by him or by his successors. Recopilación de leyes de Indias, Book III, Title I, Law I.

44 On the incorporation of the Indies to Castile see Manzano Manzano (1948). More recently, and with special treatment by legal literature on the topic, BARrientos Grandón (1999). 
As is well-known, ius commune jurists basically distinguished two methods of union between kingdoms: aeque principaliter and accessory. In the words of Crespí in the 17th Century, the kingdoms or provinces joined under an aeque principaliter union "retain their own nature and keep it separate, as though they were still ruled by the same princes prior to the union, each keeping the same law as if they were to remain separate." ${ }^{45}$ In contrast, where a province was added or joined to a kingdom under an accessory union, they became a single kingdom governed by the law and privileges of the kingdom to which they were united. ${ }^{46}$

As regards Spanish American territories, the accessory nature of their union to the Kingdom of Castile rapidly caught on. The lack of consolidated Christian kingdoms in the New World, such as that of Navarre in the Old, made it easier to consider those foreign lands a mere extension of the Old World, and especially of Castile. That is why, from the outset, Castilian Law was applied generally in the Americas, together with the old ius commune, which was also that of the New World, as well as the new local laws, expressed in a host of written or customary sources. From this standpoint, the order of the sources applicable in Spanish America did not give rise to any particular dispute, as had been the case in other conquered territories, such as Navarre. ${ }^{47}$ According to the Ordenanzas de Audiencias [Ordinances of Audiencias] of 1530, Emperor Charles V had ruled that, were the provisions issued for Spanish America not to apply, the laws of the Kingdom of Castile would apply in accordance with the Leyes de Toro [Law of Toro]. This principle was reproduced in the Recopilación [Compilation] of 1681, along with another law whereby "such cases as may not be determined by the laws of this Recopilación shall be subject to the laws of the Recopilación y Partidas [Compilation and Seven-Part Code] of this Kingdom of Castile." ${ }^{\mathbf{4 8}}$

On the other hand, in the Ordenanzas del Consejo de Indias [Ordinances of the Council of the Indies] of 1571, Philip II had mandated that the "States

45 Regarding the Catholic Monarchy, this Catalan jurist stated "Regna Castellae, Aragoniae, Lusitanae, Flandriae, Neapolis et Siciliae, unita esse in Monarchia Hispanica aeque principaliter: Regna vero indiarum occidentalium unita esse accessoriae Regno Castellae, et Indias Orientales regno Lusitaniae." Crespí de Valdaura (1677) 187.

46 Crespí de Valdaura (1677) 187.

47 See Galán Lorda (2012).

48 Book II, Title I, Laws II and I. 
(of the Indies) be governed according to the style and regime prevailing in the Kingdoms of Castile and Leon," as they were part of a single Crown. ${ }^{49}$ Thus, the Indies reproduced the institutional and legal regime of Castile, even where the special circumstances of those lands altered the original model from the beginning, which means that there was a process of territorialization of the new dominions, by virtue of which they became political spaces vested with jurisdiction. This process included the division of the Spanish American territory into major provinces, ruled by their respective Audiencias, and minor provinces, as well as the foundation of cities.

However, the distinction made by legal scholars between aeque principaliter and accessory unions was unable to adequately explain the articulation of a universal Monarchy, such as that of Spain, and, in particular, the union of an entire continent to a Crown, such as that of Castile. ${ }^{50}$ The fact that Crespí or Solórzano have written that the Indies had joined Castile under an accessory union did not mean that this legal construction properly reflected the institutional and legal reality of the New World under the Catholic Monarchy. In my opinion, putting, for such purpose, the so-called Kingdoms of the Indies and Kingdoms of Grenade or Murcia on the same footing as territories which had joined Castile under an accessory union showed the rigidity of the legal "categories" used, which evidenced the limitations of legal theories conceived at a time when there was only one world: the Old World.

Accordingly, as time went by, the territorial status of the Indies, as provinces which had joined Castile under an accessory union, was gradually overtaken by reality. They shared Castile's political status, since they were part of it, as if they were a mere extension of its territory. Nevertheless, their

49 Book II, Title II, Law XIII: "and because the kingdoms of Castile and the Indies belong to one Crown, their laws and government system ought therefore to be as alike as possible. The members of the Council shall try, in the laws and institutions which they may establish for those States, to reduce the form and manner of their government to the style and order by which the kingdoms of Castile and Leon are ruled to the extent allowed by the diversity and difference of lands and peoples." Philip II, Ordinance 14 of the Council of 1571.

50 The limitation of this distinction to explain the complexity of the unions between kingdoms in the Modern Age has been highlighted by Elliott. The English historian cited as an example the union between England and Scotland in 1707, a type of union that does not fit fully into any of these categories. ELLiot (2009) 15. 
exceptional nature under the Spanish Monarchy, characterized, inter alia, by their vast territory located thousands of kilometers away from the Peninsula, their abundant natural resources, and, more particularly, the diverse ethnic groups among their inhabitants, was also reflected in the institutional and legal framework.

It was not easy to establish a legal regime to govern that territory by resorting to Castilian Law only, based on the categories of ius commune. Both laws were transplanted to Spanish America but they underwent profound transformations. Moreover, that legal regime had to be supplemented with a myriad of provisions issued by both the Court and the different instances of Spanish American governments. But, as Tau has determined, the source of law that better adapted to the new needs was custom. ${ }^{51}$ The specific nature of this new law did not reflect only in the well-known Recopilación de Leyes de Indias [Compilation of Indias' Law], a compilation promulgated by Charles II in 1681 which had no parallel in the territories that had joined Castile under an accessory union; it found its greatest expression in the customary dimension, both in the so-called Republic of Spaniards and Republic of Indians. In this light, although it is important to realize that there was no legal regime of the Indies as such, different from that of Castile, this conclusion is considerably played down, if not in the context of jurists' discourse - with its mere conceptual distinctions - than in the context of law in action.

The particularity of those lands was not only reflected in the legal sources, but at the institutional level as well. Suffice it to mention, the institutions created ex novo or the legal entities under ius commune for the government of indigenous peoples, such as encomiendas or indigenous villages. In other cases, legal solutions originally conceived for other situations were applied, with a broad use of analogy as a tool to construe and organize these new realities. The most evident case, which most directly affects our topic, is probably giving indigenous peoples the status of "miserable" persons, one given by ius commune to "rustics", "widows", or "underage orphans". 52 Thus, indigenous peoples or Indians, who had had their natural freedom and their condition as vassals of the Crown recognized from as early as 1500 , became legally incorporated in the corporative regime of the Monarchy, although in

51 Tau Anzoátegui (2001).

52 See Duve (2004). See also Duve (2008). 
a situation comparable to the underage, that is, under the Sovereign's tutelage through its officers in the Americas.

This shared legal condition cannot be understood in terms of social homogenization. The "Indians" were in reality a creation of the conquest. Before the Spaniards' arrival, the American continent was populated by highly diverse ethnic communities: the Mayas, Aymaras, Mexicas, Araucanians, etc., but not by "Indians." After the conquest, and under the umbrella term of "personae miserabiles" "Indians" kept on forming heterogeneous groups, engaged in different activities, with very diverse rights and obligations which evolved over the years. Hence, these communities, forming the so-called "Republic of Indians" which, in turn, consisted of a plurality of "personal" statutes, did not remain the same over the Centuries either.

The consequences of the military, cultural and legal conquest of the territory among natives in those lands are explained by different factors. A few of them include: the transformation of their old traditions; their acceptance or rejection of the conquerors; their capacity to survive diseases then unknown, or the violence and mistreatment by the Spaniards; and their adaptation to new religious and cultural patterns or to the political mechanisms imposed by the Crown. In some cases, the final result was the mere extinction or the drastic reduction of the American Indian population; in other cases, it was the compulsory or negotiated integration into a new social and political structure, the Spanish Monarchy, in which they would interact with other groups and communities in an ongoing process of identity redefinition. There were also examples of escape to the margins of the system over the Centuries, a prolonged resistance which could still not avoid cultural and economic exchanges with the Spaniards.

Eventually, given this plurality of underlying situations, an Old Regime society was reproduced in the Americas, based on socio-political, rather than economic, criteria. As historiography has often shown, a corporative society was established out of dependency relations articulated in more limited geographical areas, mainly in cities, towns, villages or farms, based on a common religion and united under the Sovereign, of whom everyone was a vassal. As late as 1806, in an inquiry on marriage and access to offices by mulattos, the Council of the Indies stated that

"It is undeniable that the existence of different hierarchies and classes is of the utmost importance for the survival and proper governance of a Monarchy, where gradual and linked dependence and subordination achieve and maintain the lowest 
vassal's obedience of and respect for the Sovereign's authority, a system all the more necessary in the Americas, given the greater distance from the throne (...).53

This does not mean that economic criteria were irrelevant; they were simply not recognized for the social and cultural role they would play during the 19th and 20th Centuries. Accordingly, despite the existence of conquerors and conquered, or exploiters and exploited, it is inappropriate to analyze Spanish American social reality solely in these terms, especially after the first conquest period. ${ }^{54}$ It would be further inappropriate to represent such social reality by placing a subordinate class, the "Indians," against another, the white, that would appear - by contrast - as "independent" or "dominant." As can be clearly inferred from the words of the Council transcribed above, the entire American society, as well as European societies, consisted of groups or estates that depended on each other, to a greater or lesser extent, despite their different manifestations. However, a phenomenon emerged in the Indies which was unprecedented in the Peninsula: the existence of ethnic subordination criteria that affected particularly the native inhabitants of those lands. These dependence-based relationships were part of a pre-modern political system, ideally based on patterns of inequality, under which they made sense. Nevertheless, this observation entails no justification whatsoever, nor does it in any other pattern of inequality existing in those times.

The level of social integration and stability achieved in the Americas can only be understood from a different social model, that of estate-based structures under the Old Regime. In this regard, as emphasized by Poloni-Simard, integration was possible, among other reasons, because in Spanish colonization, the King's justice - channeled through its officers - was established at the core of social relationships. ${ }^{55}$ This should not be construed as supporting any idyllic representation of Old Regime societies, let alone the one created

53 In this same inquiry, the Council judged that equating mulattos with whites in issues which were the subject matter of the inquiry "would bring about disputes, alterations and other consequences which must be avoided in a Monarchy, where the classification of classes contributes to enhanced order, security and good governance, and where opinion prevails over the ideas of equality and confusion." Consulta del Consejo sobre la habilitación de pardos para empleos y matrimonios, Madrid, julio de 1806, in KonetzKe (1962) 825 and 822.

54 In this regard, see Pérez Herrero (2002) 117.

55 For this author, "la justice doit être envisagée comme l'institution centrale de la colonisation espagnole en Amérique entre XVI et XVIII ${ }^{\mathrm{e}}$ siècle”. Poloni-Simard (2003) 197-198. 
in the Spanish Indies, but merely highlights the shared social, institutional and imaginary mechanisms that allowed for the operation and maintenance of such an unequal political system. Justice, whether secular or ecclesiastical, enjoyed a privileged position in dispute mediation and the preservation of a system deemed pre-established. We should further mention other contributing factors, whose analysis exceeds the scope of this paper. ${ }^{56}$

Likewise, the "Spanish American specificity" translated into the adaptation to the new environment of institutions typically Castilian, such as the audiencias and municipios, which, without radically altering their original features, adopted their own profiles in the Indies. ${ }^{57}$

The creation in 1524 of a supreme Council, the Council of the Indies, is even more relevant to our subject of analysis. ${ }^{58}$ The creation of this supreme court symbolically placed the Indies on an equal footing with the other kingdoms which had been united under an aeque principaliter union in the figure of the Monarch. The Councils were the utmost institutional expression of the plurality which characterized the Catholic Monarchy. As Crespí de Valldaura expounded after describing this plural structure, the inability of Sovereigns to administer justice in person in each and every territory called for the constitution of some kind of "common homeland" of the entire Monarchy where every province and its subjects could have justice dispensed. In this "curia regia" - as Crespí went on to say - jurisdictions should not overlap, but be fairly divided, as though justice were administered in every province, so that the supreme Council of Castile did not hear cases pertaining to the kingdoms of the Crown of Aragon, which were to be substantiated in the Council of Aragon, just like Italian cases had to be heard by the Council of Italy and Portuguese cases, by the Council of Portugal. ${ }^{59}$

Thus, the "polisinodial" regime reflected the "plural" constitution of the Monarchy, serving as a link between the Sovereign and his subjects. As Bermúdez de Pedraza put it,

"The superior government of this Monarchy is admirably divided into twelve Councils, business being divided by kingdom and subject-matter. Each of these Councils

56 For an introduction to the topic for New Spain, see Castro Gutiérrez (1996) 19-37.

57 This "Americanization" of audiencias is discussed by Diego-Fernández (2000). For municipalities in the Americas, see Pazos Pazos (1999).

58 Schäfer (1935) 44; Ramos Pérez (1969).

59 Crespí de Valdaura (1667) 187-188. 
is composed of a mystical body, the head of which is the President, the members of which are the Counselors, and the field of competence of which is the business assigned thereto. The presidents do not usually vote on matters of justice, but are the immediate means of communication between His/Her Majesty and His/Her Kingdoms." 60

The Council system was a more or less functional solution to the problems arising from governing a complex framework of territories through the Court. Furthermore, the Councils were also the meeting point between the King, on whose behalf they acted, and the territories subject to his jurisdiction, which they also represented, that is to say, which they caused to appear in spirit before the King. In such regard, Solórzano stated that "the quality and prominence of Councils and Magistrates is observed and regulated by that of the kingdoms and states they rule and represent." ${ }^{\text {"1 }}$ Similarly, in a footnote, this jurist noted that the Councils worked with Ambassadors who were "more or less honoured, and preferred according to the place and status of the Princes or Provinces they sometimes represented." ${ }^{2}$ Hence, inter alia, the relevance of conflicts over precedence among Councils was such that, from our viewpoint, alien to the culture prevailing at the time, it is impossible to understand. In this case, and on the basis of these assumptions, Solórzano did not hesitate to assert the prominence of the Council of the Indies over the Council of Flanders in public acts, since the former was in charge of "not only the government of a county or kingdom, but that of an empire which embraces so many kingdoms and such rich and powerful provinces, or, in better words, the broadest and most extended Monarchy the world has ever known, as it actually comprises another world." ${ }^{3}$

60 Bermúdez de Pedraza (1635) 1-3, cited in: Rivero Rodríguez (2004) 507.

61 Solórzano y Pereira (1776) 177.

62 Ibid. (1776) 177.

63 Ibid. 178. In another passage of this same memorial, Solórzano states that by virtue of the accessory union it might be understood that the Empire of the Indies, just as its governing Council, is part of that of Castile (p. 188). He also explains that the Council of the Indies came into being as a result of the development of business on those lands, so it is possible to assert that once the administration of these matters was removed from the Council of Castile, "authority [remained] united as a whole." (p. 189). These statements, which apparently deny the personality of the Council of the Indies as a separate institution from the Council of Castile, ought to be interpreted within the framework in which Solórzano formulated them, i.e., to prove the seniority of the Council of the Indies over that of Flanders. In a different paragraph of this memorial, he argued that the Council of the 
As Rivero has pointed out with reference to the Council of Italy, this representative dimension of Councils endowed the different territories subject to their jurisdiction with unity and provided them with organicity, within their corporate jurisdictional structure, just like the other kingdoms and crowns. ${ }^{64}$ That is how the Council of the Indies acted in relation to Spanish American land. In spite of its great diversity and the complexity of its jurisdictional structures, linked to the very evolution of the process of conquest and colonization, the existence of a Council of the Indies, gradually distinguished from that of Castile, also led to the endowment of those territories with a certain political status of their own within the Castilian Crown. However, this process was not automatic. As we have already stated, in 1511 there was a Board within the Council of Castile, responsible for hearing issues pertaining to the Indies, while in 1524 it became a separate Council. Under the Ordenanzas de 1571 [Ordinances of 1571], Philip II prohibited the other Councils and courts from intruding by hearing issues pertaining to the Indies, thus consolidating its position within the system of Councils, as well as that of the Indies within the Castilian Crown. ${ }^{65}$ In 1600, just like the Council of Castile, the Council of the Indies was provided with its own Chamber for the allocation of benefits and offices in the Indies. ${ }^{\mathbf{6}} \mathrm{In}$ 1614, Philip III ordered that no mandate served by another council be observed unless it had already been submitted to the Council of the Indies. In 1626, Philip IV mandated that no pragmatic sanction promulgated in the Kingdoms of Castile be enforced in Spanish America, unless a mandate issued by the Council of the Indies ordered that it had to be observed. ${ }^{67}$ Ten years later, this same King conferred ecclesiastical powers upon the Council of the Indies, thus inhibiting the Council of Castile. ${ }^{68}$

Indies is truly Supreme, without possible recourse to any other tribunal, as Philip II expressly established in the second ordinance of 1571 (p. 198).

64 Rivero Rodríguez (2004) 507.

65 Recopilación de leyes de Indias, Book II, Title II, Law II: "the Council of the Indies shall have supreme jurisdiction over the West Indies, whether already discovered or to be discovered, and the business arising therefrom and depending thereon, and for their good governance and judicial administration it may issue Orders and consult with our Laws, Pragmatic Ordinances, etc."

66 SCHÄFER (1935) 179.

67 Recopilación de leyes de Indias, Book II, Title I, Law XXXIX.

68 Recopilación de leyes de Indias, Book II, Title II, Law III. 
If, within the Court, the foundation of the Council provided an institutional dramatization of the unity of the New World without altering its legal status - that of a territory which had joined the Crown of Castile under an accessory union - in the Indies, the consolidation of a civic culture and the formation of a creole elite enabled the gradual formulation of a self-defining discourse, which, on the basis of its urban location, also referred to the Indies as an entity distinct from Castile within the realm of the Spanish Monarchy. This discourse revolved mainly around the natural obligation of reserving offices for the natives of those lands. ${ }^{69}$ Logically, this was aimed at defending local offices from Castilians. The purpose was to turn Spanish America into a perfect community, a separate territory within the common Spanish Monarchy, as was Navarre. Since the late 16th Century, this discourse was accompanied by a remarkable increase in the level of self-government of local powers in the Indies, which was mostly achieved by means of the purchase of most of the offices in Spanish America, in particular, in audiencias and cabildos. ${ }^{70}$

2. The Bourbons and the Hispanization of the plural Monarchy

When Charles II died, the Spanish Monarchy had a plural composition where the Indies had gradually acquired some political entity, both on the institutional level and that concerning political discourse. On the basis of these assumptions, the establishment of the Bourbon Dynasty has been traditionally construed as the beginning of a clear change of direction. Thus, the enthronement of Philip V would not have entailed just the extinction of the judicial and executive institutions proper to the territories of the Crown of Aragon and, accordingly, their disappearance as a political entity different from the Crown of Castile, but, in particular, it would have entailed the beginning of a new way of thinking "Spain," focused on the increasing centralism and authoritarianism of the successive Monarchs. This process would have concluded in the reign of Charles IV with the influence of the almighty Godoy, whose despotism would have led directly to the crisis of the Monarchy and, consequently, to the extinction of the Hispanic Empire, except for some colonies such as Cuba, Puerto Rico and the Philippines.

69 See Herzog (2004); Garriga Acosta (2003).

70 See the already classic Burkholder/CHANdLER (1977). 
Now is not the time to criticize this reading of 18th-Century Spain, rather consolidated in historiography, or to trace the origins of this constructive paradigm. ${ }^{71}$ Clearly, there are many reasons supporting this interpretation. In addition to the Nueva Planta Decrees and the patrimonial understanding of power behind the acts by Philip $\mathrm{V}^{72}$ there are many other measures evidencing the Crown's increasing interest in having more expedite and effective mechanisms for decision-making and the enforcement of policies, as well as in recovering positions of power. In this regard, we should mention, by way of example: the creation and development of the Secretariats of State [Secretarias de Estado y del Despacho]; the creation of intendencias; the professionalization of the army; the (temporary) suppression of internal customs; the rationalization of the tax system; the reform of the system of fleets and galley slaves; and the introduction of the company system in peripheral regions, or the struggle to control the sale of offices.

However, we should not lose sight of the "structural" limitations imposed by the very "constitution" of the Monarchy upon any process of nationalization and standardization of the political territory. Despite these and other measures of great significance adopted by successive Bourbon kings, the Spanish Monarchy maintained its institutional plurality and its jurisdictional structures. The Secretariats of State did not suppress all secular councils. In fact, some of them, such as those in Castile or, to a lesser extent, in Navarre and the Indies, continued playing a key role in the governance of their respective territories. ${ }^{73}$ On the other hand, intendentes coexisted with corregidores and alcaldes mayores in the Peninsula and in the Americas, and the audiencias maintained their leading role over this period. We should further mention the importance of ecclesiastical jurisdiction and the different special jurisdictions largely dividing public space and limiting any monopolistic claim of political power. This institutional "duplicity," which has led historiography to talk about the conflictive coexistence over this Century of two

71 An explanation for the first half of the Century, based on propaganda by the supporters of the Bourbon dynasty in the succession conflict can be found in STIFFoni (1989).

72 On the patrimonial logic behind the measures adopted by Phillip V, see Fernández Albaladejo (1992) 380; Garriga Acosta (2006) 94-96.

73 Sesé Alegre (1994); García Pérez (1998). On a more favorable view of the relegation of the Council of the Indies as a consequence of the creation of the Secretariats of State, see Bernard (1972); Cabrera Bosch (1993). 
parallel or overlapping Monarchies - one "administrative," the other "jurisdictional",$-{ }^{74}$ explains some of the difficulties in understanding the 18 th Century from the perspective of the operation of different power dynamics.

Such diversity of institutional structures and logic of power can be clearly seen at the higher governmental levels of the Monarchy. In this case, the Council of the Indies saw its authority disputed by the creation of a Secretariat of State of the Navy and the Indies. It was established in 1714, together with the Secretariats of War, State and Justice, which reflected not only the implementation of a new form of government in matters related to the New World, but also the consideration of the Indies as a mere branch of "administration," along with others such as the Navy or War. In a sense, the measure could be construed as a denial of the political status implicitly recognized with the creation and consolidation of a Council of the Indies over the previous two Centuries, coexisting with other councils for other territories of the Monarchy.

In the 18th Century, the Secretariat of State had a checkered evolution. ${ }^{75}$ It was removed in 1715 , restored in 1720 as Secretariat of War, the Navy and the Indies, only to become the Secretariat of the Navy and the Indies in 1721. In 1754, its structure changed when matters pertaining to the Indies were separated from those pertaining to the Navy, to form two separate Secretariats of State which, nonetheless, were still headed by the same Secretary. In 1787, upon the death of Gálvez and the creation of the Junta Suprema de Estado [Supreme Board of State], the Secretariat of the Indies was split into two with a view to expediting the handling of matters in the Americas. In 1790, in line with Floridablanca's projections to join interests on both sides of the Atlantic, matters concerning the Indies were distributed among the other five Secretariats of State, a solution that had already been contemplated in the instruction reserved for the Junta de Estado (No. CXLV). This was aimed not only at streamlining and securing "Treasury and War expenses, resources and assistance" on both hemispheres, but also at "largely deterring hatefulness for such separation of interests, charges and objects,

74 On this regard, see the classic work by Hinrichs (1986). On the difficulty to subsitute the jurisdictional power model with one purely "administrative" in the Old Regime, see MANNORI (1990).

75 See Gómez Gómez (1993); Escudero (2001). 
which destroys the Spanish Monarchy and divides it into two Empires."76 However, as explained below, Floridablanca's non-colonial idea of governing the Americas was not the only one, and not even the most prevalent in the Court, during the second half of the 18th Century.

The fact that most matters concerning the Americas were handled through the specific channels, that is, through the relevant Secretariat of State, did not downplay the leading role of the secular Council of the Indies. While still being the highest court for Spanish American matters, the Council also experienced a change in composition in the reign of Charles III and became a benchmark for most of the reforms introduced in the Americas during those years. ${ }^{77}$ Its continuity over time was, on an institutional level, a clear manifestation of the specific nature of the Spanish American territories within the Crown of Castile. It was also a clear manifestation of the ongoing idea of government linked to the right of justice.

Within the framework of this institutional complexity, merely outlined here for the peak of the Monarchy, the Ministers of Charles III adopted the policies to be implemented after the defeat in the Seven Years' War along lines that had already been anticipated during the previous two reigns. On the international level, the imperial expansion of foreign powers, mainly England, France and Holland, demanded political action to ensure Spanish dominion over the New World. After the independence of the thirteen colonies in America, it became even more necessary to change a traditional system of government that had allowed a high degree of self-government in those lands.

In this context, we can also gain a better insight into the consolidation of a discourse and politics with colonial features in the Court, as well as the reactions this caused among the elites of the Indies. It was at that moment, in the 18th Century and not before, that the Indies were referred to as colonies for the first time. It should be noted, however, that just as it is not possible to reduce the 18th-Century institutional structure of the Monarchy to a consistent and systematic unit - since it was more the outcome of a historic development marked by a collection of different institutional logics rather than the design of a Cabinet projected over an empty space

76 EsCUDERo (2001), II, 68.

77 I have dealt with this matter in Garcia Pérez (1998). This "rebirth of the Council" was brought to attention by BuRKHOLDER (1976). 
available to the Sovereign -, neither is it possible to unitize the different policies issued by the Court for the Americas in the 18th Century, or any supporting discourse to legitimize them. Therefore, while focusing on the emergence of a true "colonial" discourse in the 18th Century, we should not overlook its coexistence with other discourse of a different nature, aimed at achieving a better unity of interests between Creole elites and the Crown. We have just seen this when discussing the extinction of the Secretariats of State for the Indies in 1790, with Floridablanca leading the King's Ministers. Some years earlier, in 1768, the extraordinary Council formed in the Council of Castile had articulated the need to send Spaniards to the Indies to hold "the major offices, Bishoprics and Sinecures, and to have the Creoles hold equivalent offices in Spain." This would establish stronger ties and lead to a "united Nation." The goal was to ease tension in the Americas after the expulsion of the Jesuits and to deter any independence movement. ${ }^{78}$

In addition to this unifying discourse, we should mention the persistence of old political conceptions over the whole 18th Century, in line with the prevailing ideas of previous Centuries. In light of this plural background, we may assess the scope of colonial discourse supported by some Ministers and materialized in the adaptation of specific political measures for the Americas during the last decades of the Old Regime.

\section{Colonial discourse and its institutional incidence}

It is not our intent to discuss here in detail the reforms initiated by the Crown since 1763: the policy of appointment of senior officers that privileged the Peninsulars vis-à-vis the Creoles; the extension of the system of intendencias to most of the Americas; the creation of new viceroyalties and provincial boundaries; the introduction of significant tax reforms; the formation of a permanent Royal Army, and the implementation of the militia system, etc. ${ }^{79}$ While we cannot state - as noted above - that the Court had developed a consistent political program for the Americas, since actors, interests and principles

78 The report is reproduced by Navarro García (1996). Quotes on page 205.

79 Historiography has given considerable attention to the reforms in Spanish American politics in the 18th Century. For a general vision, with the corresponding bibliographic references, see Pérez Herrero/Naranjo Orovio/Casanovas Codina (2008); Lynch (1991); and Navarro García (1991). 
involved in the adoption and execution of such decisions varied to a great extent, we can state that there were some goals behind many of the reforms carried out during the second half of the 18th Century.

On the one hand, as often underlined, "Bourbon reforms" were aimed at securing the defense of Spanish American territories. Financing such an endeavor required a considerable increase in the revenues from the Americas. Though the target of these policies was the Americas, they focused basically on Spain, on the preservation of its Empire in an international setting different from that of previous Centuries. At the same time, within the context of the Audiencias - a centerpiece of the American government -, action was taken to restore a justice system that had been shaken over decades by practices such as the sale of Court offices or, more generally, the deep-seated roots of judges in the Indies society. ${ }^{\mathbf{8 0}}$

These reforms were accompanied with the simultaneous publication of projects concerning the government of Spanish America. The presence of enlightened ideals of government among many of the Court's Ministers, with emphasis on the virtues of trade and economic development towards peoples' progress, and the exemplary policy promoted by foreign powers for their overseas domains, also led Spain to work on new governmental proposals for the Americas, whereby such lands could emerge from "their state of decadence," a popular cliché then. In most cases, the proposals were clearly in line with those adopted during the first half of the Century by authors such as Macanaz, Jerónimo de Ustáriz or the author of "Nuevo sistema de gobierno para la América" ["New Governmental System for the Americas"], dated 1743 and mistakenly attributed to José del Campillo. ${ }^{81}$ Even if it is possible to establish a connection between the theoretical proposals and the institutional reforms, it is always advisable to maintain both areas well differentiated. Both are important from a historical point of view. Both reveal the ideas then prevailing in the Court's circles about the right position of the Americas within the Spanish Monarchy. However, their practical significance has not been the same.

The terms used by the Ministers and senior Officers of Charles III, in addition to the terms "Kingdoms" and "Provinces," predominantly used in the political jargon, particularly in the legal area, now included the term

80 See Garriga Acosta (2002).

81 See Navarro García (1995a). 
"colonies." Yet, the term was often reserved to refer to colonies of foreign powers, i. e., French, English, Dutch, or Portuguese colonies. While an empirical study should be conducted to assert this unmistakably, any historian acquainted with 18th-Century archive sources would be able to note it.

In other cases, the use of the binomial metropolis-colonies reveals the modernization of a discourse that was still based on traditional guidelines or, at least, that had not yet adopted the patterns of modern colonialism. There are many examples in that regard, but let us focus on the policy pursued by the Crown in the Americas during the reign of Charles III. We refer to the well-known plan of intendencias designed by Gálvez after visiting New Spain, and the reports prepared by the Bishops of Puebla and "this metropolis," i. e., Mexico, as mandated by the Viceroy of New Spain, the Marquis de Croix. ${ }^{\mathbf{8 2}}$

After a careful reading of the project, one can note the coexistence of colonial languages and policies with others consistent with reformist premises of the Old Regime, where the preservation of the political order appears related to the effectiveness of mechanisms ensuring officers' good behavior and fairness. The reform proposed by Gálvez is intended to "standardize both the government of these great Colonies and the government of the metropolis," since intendencias had already been introduced into the Peninsula fifty years earlier. While Gálvez uses the terms "colonies" and "metropolis," the standardization of the former and the latter is inconsistent with politics of a colonial nature. Spanish Americans could consider it despotic - rather than colonial - action to the extent it violated acquired rights. The problem lay in the fact that "the huge kingdoms of Spanish America" were in decline because they maintained a government "that imitated the metropolis' former government." Therefore, it was logical to apply in those lands "the healthy remedies that had cured the ills of its head." ${ }^{33}$

According to Gálvez, the problem was that the existing system of government in "this important and extensive Monarchy of New Spain" prevented the Viceroy from "establishing good order and justice." The fact was that the one hundred and fifty alcaldes mayores and corregidores, having no salary, did business in such lands to the detriment of the King's vassals and to the Crown itself, which lost substantial income. The creation of the office of

82 "Informe y plan de intendencias que conviene establecer en este reino de Nueva España", reproduced in Navarro García (1995b).

83 Navarro García (1995b) 112-114. 
intendente was, in the opinion of Gálvez, the remedy for this "ruinous constitution." 84

At the same time, the plan included indications that revealed the subordination of American to Peninsular interests, such as the references to setting up factories "prohibited in the Colonies." It was not Gálvez's original idea. From this standpoint, the subordination of manufacturing companies in the Indies to Peninsular interests had been supported some years earlier by the author of Nuevo Sistema de Gobierno. ${ }^{85}$ However, this was neither the only nor the primary goal of Bourbon reformist policies, aimed rather at regaining control over power structures on both sides of the Atlantic and at securing the integrity of its possessions in the Americas. ${ }^{\mathbf{8 6}}$ Likewise, attributing "natural neglect and laziness" to indigenous people was not new either. Nonetheless, the proposal insisted on the need to eradicate a business that caused considerable harm: the distribution of merchandise. ${ }^{87}$

The report prepared by the Bishop of Puebla, strongly in favor of Gálvez's proposals, focused on the need to standardize government on both sides of the Atlantic; however, neither the language used nor the proposals made allow us to talk about the emergence of a new colonial mindset. Firstly, the Bishop denied the novelty of the project, as it already existed in Spain. Expanding it into the Americas - he explained - would avoid losing many souls and would put an end to the ill-treatment of indigenous people by alcaldes mayores and to the damage caused to the Royal Treasury. The plan was justified by its effects and by itself: Since Spain (identified with Castile) and the Americas formed "a single Kingdom," they should move towards standardized government inasmuch as possible, as vindicated by the history of colonization. The Bishop was not thinking about other foreign powers' external policy, but that of ancient peoples. Conquering nations transformed conquered nations, basically by reciprocal marriage. Therefore, it was desirable that Spanish and native families be joined in marriage, at least principals' and caciques' families. A very different consideration was given to plebeian Indians, incapable of governing themselves. ${ }^{\mathbf{8}}$

84 Ibid. 112-114.

85 Campillo y Cosío (1789); Ward (1779).

86 Perez Herrero/Naranjo Orovio/Casanovas Codina (2008) 40.

87 Informe y plan de intendencias (n. 82) 123, 125. Gálvez's plan is dated 15 January 1768.

88 Report of 20 January 1768. Navarro García (1995b) 128-130. 
On the other hand, dependence on Spain was also justified in accordance with traditional reasons. The Indies were members of the Spanish Monarchy, branches of a tree, and, as such, should bear fruit. Intendencias would not only put an end to vassal suffering, but also report substantial profits to the Royal Treasury. ${ }^{89}$

The Bishop of Mexico approved the plan proposed by Gálvez too; he considered the abusive behavior of alcaldes mayores to be the root of all evil of Spanish American government. Intendentes would fill the gap between alcaldes mayores and viceroys. They were even more necessary than in Spain, where inhabitants of villages were more rational. Although he did not dwell on more theoretical considerations, he did make reference to the conquest in order to stress the need to accommodate natives' lives to the conquerors' laws and customs. ${ }^{90}$

The goal set by the Crown to regain control over power structures in the Americas, in order to guarantee that justice be served and that all necessary resources to enforce its Atlantic policy be extracted, ended up - as is well known - with Gálvez as Minister of the Indies, in an attempt to exclude Creoles from holding major political and judicial offices. ${ }^{91}$ However, it is one thing to have measures adopted in Court, and quite another to implement them in America. In either case, it is clear that both the underlying discourse of most projects as well as the measures implemented in the second half of the 18th Century impaired the rights and interests of many American elites. In both cases, a utilitarian vision of the Americas was gaining momentum, which translated into a divergence between Monarchy and Nation. The Indies were part of the Monarchy's - but not of the Nation's discourse. $^{92}$

It was a process already under way. The loss of Spanish dominions in Europe after the War of Succession favored the "nationalization" of the Monarchy. Castile increasingly consolidated as its center and, consequently, a periphery started to develop. With the encouragement of the Court and the support of different cultural groups, an interpretation of history inclined to identify Castile with Spain was evolving. ${ }^{93}$ However, this process encoun-

89 Ibid., 131.

90 Report of 21 January 1768. Ibid., 131-134.

91 Burkholder/Chandler (1977) 103-106.

92 Portillo (2000); Portillo (2006) 32-34.

93 For the development of Castilian legal history as Spanish legal history, see Vallejo (2002). 
tered resistance in certain territories, such as the Basque Provinces and the Kingdom of Navarre - especially -, which, since ancient times, had had their own laws, governmental and judicial institutions. Here also an alternative discourse of a constitutional nature emerged which, as would be the case in the Americas, tended to emphasize its "separation" from Castile, that is, its essence as a perfect political community, whether as a province, dominion or kingdom.

Yet, the consequences of the establishment of a Spanish Nation partially different from the Monarchy were not the same for Peninsular and oceanic territories. Navarre and the Basque Provinces were still part of both, even though their rights and liberties, particularly in the fiscal and military areas, were increasingly challenged. Conversely, the Indies appeared more and more as areas politically available to serve the interests of the Monarchy's principal Domain, namely the Nation. In this regard, it is no coincidence that one of the Ministers who, as prosecutor of the Council of Castile, had played a more prominent role in the conflicts between the Kingdom of Navarre and the Court since $1770,{ }^{94}$ Pedro Rodríguez de Campomanes, was also the author of one of the treatises that best featured the subordinate nature of the Indies to the Nation, to which - seemingly - they did not belong. This can be noted by merely reading the acknowledgment at the beginning of his treatise "Reflexiones sobre el comercio español a Indias [Reflections on the Spanish Trade to Indias]". 95

94 I refer to the conflicts over levies and transfer of customs houses. In this context, Navarre was forced to develop an elaborate constitutional discourse in defense of their fiscal and military rights and liberties. Allow me to refer you to García Pérez (2008) 205-262.

95 To Campomanes, the decadence "of our farmers and craftsmen is that there is no dispatch of the fruit of their work or craft," which damaged the strength of the Monarchy, based on "its population and its trade." However, Campomanes wondered "Who will believe, Sir, knowing that Your Majesty dominates the largest and best part of the Americas, where there are many millions of Your Majesty's vassals, that these goods have no dispatch?" The work he presented was aimed at revealing the cause of this evil which - in the words of the prosecutor of the Council of Castile - could only reside "in the body of the Nation or in the rules hitherto observed on the traffic to and from the Indies." The problem was, indeed, in the rules. The trade ban imposed "on the Americas ports is far from admirable - he noted - as the Colonies should not have concurrent navigation with the matrix. But it is unprecedented for Spain to suffer this exclusion." In this context, the Indies were not the Nation, but colonies at its service. Campomanes (1988) 3-4. 
The unequal condition of the Indies is similarly noticed in the wellknown projects developed by Intendente José Ábalos (1780), by the Count of Aranda (1783), and by the almighty Godoy (1804) - which was even known and approved by Charles IV -. All of them agreed on the convenience of dividing the Indies into several Monarchies led by members of the Spanish Royal Family. ${ }^{96}$ Regardless of the feasibility of such proposals, the Indies were described as territories politically available to the Monarch. In practice, this was clear during Godoy's government with the transfer of Santo Domingo to France in 1795, and Louisiana and Trinidad to England in 1800 and 1802 , respectively. ${ }^{97}$

However, the key trigger for the creation of a discourse of colonial denunciation was the crisis of the Monarchy after the entry of French troops into Spain and the abdication of the Spanish Monarchs in favor of Napoleon. The ensuing power vacuum and the different solutions then defended provided the perfect framework for the development of an anti-colonial discourse in the Americas. In this new and unforeseen context, the term colony became instrumental in the fight between political projects on both sides of the Atlantic: within the Peninsula, in order to gain American support for the constitutional case in Cadiz and, in general, for the war of liberation against Napoleon; in the Americas, in order to support the different projects for an autonomous government at first, and an independent one later on. ${ }^{98}$ Thus, the "colonial paradigm," to quote Lempérière, evolved, a paradigm which has dominated the Latin American historiography so far.

\section{Final Considerations}

It is commonplace among historians to assert the need to understand ancient societies from their own interpretive categories. It is not an easy task. Some would consider this an illusive goal as temporal borders would make it impossible to overcome cultural ruptures. While there is no need to engage

96 Ramos Pérez (1968); Muñoz Orán (1960); RodríGuez (1976) 54-66; Navarro García (1997).

97 A paradigmatic expression of Godoy's declared colonial policy was the Board of Fortifications and Defense of the Indies, as has been pointed out by Garriga Acosta (2006) 110-120.

98 Ortega (2011). 
in these theoretical rather than practical debates, no one questions how convenient it is for a historian to avoid projecting into the past categories or concepts coined or re-elaborated in the present time to provide solutions to current world problems. ${ }^{99}$

In the case at hand, it is quite clear from what has been described in these pages that, after their conquest and incorporation into Castile, the Indies became part of the Spanish universal Monarchy. The colonization model on which the Spanish based their conquests was not the one that predominated as from the second half of the 18th Century - and particularly during the 19th and 20th Centuries -, used by the main European powers. Rather, at least ideally, it resembled the Roman model. ${ }^{\mathbf{1 0 0}}$ That is why, until the late 18 th Century the words colony and colonize were understood both in dictionaries and usage as well as in legal texts as synonyms of population and populate. ${ }^{101}$ In the second half of the past Century, the term colony acquired the modern sense of economic exploitation both in the republic of letters as in the European Courts. ${ }^{102}$

The ideal reference to the ancient colonization model does not preclude me from stating that the colonization of the Indies had particular or specific features: by way of example, and among other factors, religion enjoyed a dominant though not exclusive role. It could not have been otherwise. Historical times were significantly different. In the 15 th Century, the conquest and colonization of the Americas also involved joining the Indies to Castile under an accessory union and, consequently, transferring the Castilian legal order to the new lands. However, the different treatment required by the New World over the years resulted in a progressive increase in its

99 Gaddis (2002); Wood (2008).

100 See Padgen (2005) chapter 1. Regarding the connection between liberalism and imperialism in the mid nineteenth Century, see Pirts (2006).

101 "Colony: a town or parcel of land that has been populated by foreign people taken from the City which owns such territory or from some other place. The word colonies also meant the places populated by their ancient inhabitants, who had been granted the privileges corresponding to such peoples by the Romans (...). In Spain, there were many towns that had been Roman colonies." Covarrubias Orozco (1674) 154. The definition of the term "colony" in the Diccionario de Autoridades de 1729, 419, is practically the same. This ancient meaning of the word colony also appears in Política Indiana by Solórzano Pereira, as has been pointed out by Tau Anzoátegui (2000) 102-103.

102 LEMPÉRIÈRE (2004b) 114-116. 
political identity as a territory distinct from Castile, though formally it was an accessory part of the latter. This particular or specific feature was reflected on the institutional level, with the creation of the Council of the Indies and the particular evolution of its Audiencias and its municipios, of Spaniards and of Indians, as well as in the legal sources, with the leading role of custom and the specificity of the law of the Indies, paradigmatically represented in the Recopilacion [Compilation] of 1681. In this respect, the accessory nature of the union gradually developed turning the Indies into a territory more similar to Navarre or Aragon than to other kingdoms joined to Castile under an accessory union, such as Granada or Murcia. At the same time, a creole discourse emerged - studied from this perspective by Garriga - that viewed Spanish America as a perfect community separate from Castile. The purpose was to secure that offices to be held in the Indies were reserved for natives of those lands and not for Spaniards. ${ }^{103}$

The Castilian estate-based social order, unevenly constituted, was also transplanted to the New World but with some clear differences. In addition to the kings' policy of limiting jurisdictional dominions as much as possible, the integration of the indigenous peoples into this imported order posed not only theoretical but, mainly, practical problems. Although indigenous peoples were considered "miserable people" legally and, as such, subject to the Crown's protection, the consequences of such status were diverse, depending on the different peoples, places and times. In addition, the degree of assimilation of European culture and of the Catholic religion were also different, as well as the transformations that the native cultures underwent. In any case, and despite the relationship of subordination and dependence that the conquest entailed for indigenous peoples, together with the numerous abuses that, notwithstanding the Crown's protectionist policy, they suffered in these Centuries, the colonial relationship model - understood in its modern sense - does not seem to be the best suited to explain the place occupied by the Indies and their people within the Spanish Monarchy. In this respect, we agree with Tau when he posits the "inappropriateness of the word colony to describe generically the political condition of the Indies." No political entity in the Spanish Monarchy is referred to by that name in legal or political texts, in custom or in practice. ${ }^{\mathbf{1 0 4}}$ Moreover, the emergence of a colonial

103 Garriga Acosta (2006) 72-93.

104 Tau Anzoátegui (2000) 121. 
political discourse in the 18th Century and the adoption of measures revealing a colonial conception of the Indies did not result in a substantial transformation of the political model of the Spanish Monarchy. Therefore, from a historiographical perspective, it seems more accurate, and possibly more fruitful, to assume the legal categories used at the time to construct the Spanish American space. The Indies were provinces or kingdoms joined to the Crown of Castile under an accessory union. Henceforth, it is the duty of historians to determine the concrete meaning of these categories in each historical period, avoiding the use of schemes that are too rationalist and anachronistic to comprehend a reality which then, just as now, was beyond any simplistic approach to systematization.

On the other hand, adopting perspectives that assume a plurality of concurrent powers and jurisdictions in Spanish America, leaving aside mental structures too bound to state standards, can provide a more realistic approach to the relationships between the Crown and the New World. From this perspective, the leading role that indigenous peoples - with their rights and traditions - played in the creation of the Spanish American legal order should also be acknowledged. Without underestimating the significance of the policies the head of the Monarchy pursued, through the Council of the Indies, Juntas [Boards] or the Secretariats of State, the fact that they were focused on the places where the different social actors converged - mainly cities and towns - evidences the inappropriateness of explaining political societies of the Old Regime too flatly or homogeneously. ${ }^{105}$ In this area, dominated by the existence of patronage or family networks, or by the interaction of groups having diverse interests which, on many occasions, joined the two sides of the Atlantic, it is not sufficient to apply general binary schemes, such as Peninsular-Creole or Spanish-Indian. Also in this context, the simple opposition colonizer-colonized can leave a substantial part of the human relationships typical of the Old Regime in the Americas outside our attentional focus.

Finally, as is the case with the word "State," whether it is appropriate to use the term "colony" will ultimately depend on the meanings and conno-

105 On the need to study the history of the Nation in Spain and also of the Americas from this municipal perspective rather than from the history of the kingdoms or of the formation of the State, an author who has attracted attention, among others, is Tamar Herzog. A good example of the possibilities of this approach is Herzog (2003). 
tations the historian gives it. In this respect, it is possible to use the word colony or colonial while preserving the political logic characteristic of the Spanish Monarchy during the Old Regime. We would be dealing, in any case, with not very "colonial" colonies.

\section{Bibliography}

Acerca del término "colonia" (1954), [sesión científica 26 de enero y 22 de febrero 1954], Instituto Gonzalo Fernandez de Oviedo, Madrid: Consejo Superior de Investigaciones Científicas

Álvarez-Ossorio Alvariño, Antonio, Bernardo J. García García (eds.) (2004), La Monarquía de las naciones. Patria, nación y naturaleza en la Monarquía de España, Madrid

Barrientos Grandón, Javier (1999), El sistema del ius commune en las Indias occidentales, in: Rivista Internazionale di diritto comune 10, 53-137

Benton, Lauren (2002), Law and Colonial Cultures. Legal Regimes in World History, 1400-1900, Cambridge

Bermúdez De Pedraza, Francisco (1635), Panegírico legal. Preeminencias de los secretarios del rey deducidas de ambos derechos, y precedencia de Luis Ortiz de Matienzo, Antonio Carrero y don Iñigo de Aguirre, sus secretarios y de su consejo en el Supremo de Italia, al fiscal nuevamente criado en él, Granada

Bernand, Carmen (2003), Impérialismes ibériques, in: Ferro (2003) 137-179

Bernand, Carmen (2004), De colonialismos e imperios: respuesta a Annick Lempérière, Nuevo Mundo Mundos Nuevos, Debates, Posted on 8 February 2005, URL: http://nuevomundo.revues.org/438

Bernard, Gildas (1972), Le Sécretariat d'Etat et le Conseil Espagnol des Indes (1700-1808), Genève

Burkholder, Mark. A. (1976), The Council of the Indies in the Late Eighteenth Century: a new perspective, in: Hispanic American Historical Review, 56, 3, 404-423

Burkholder, M. A., Chandler, D. S. (1977), From impotence to authority: The Spanish Crown and the American Audiencias, 1687-1808, Columbia

Cabrera Bosch, María Isabel (1993), El Consejo Real de Castilla y la ley, Madrid

Campillo y Cosío, José Del (1789), Nuevo sistema de gobierno economico para la América: con los males y daños que le causa el que hoy tiene, de los que participa copiosamente España, y remedios universales para que la primera tenga considerables ventajas, y la segunda mayores intereses, Madrid, Imprenta de Benito Cano

Campomanes, Pedro Rodríguez (1988), Reflexiones sobre el comercio español a Indias (1762), edited by Vicente Llombart Rosa, Madrid 
Cañizares-Esguerra, Jorge (2001), How to write the history of the New World: histories, epistemologies, and identities in the eighteenth-Century Atlantic World, Stanford

Castro Gutiérrez, Felipe (1996), Nueva ley y nuevo rey. Reformas borbónicas y rebelión popular en Nueva España, Zamora (Michoacán)

Covarrubias Orozco, Sebastián de (1674), Tesoro de la lengua castellana. Digital edition 2006 by Biblioteca Virtual Miguel de Cervantes, Madrid, Biblioteca Nacional

Crespí De Valdaura, Cristóbal (1677), Observationes Illustratae decisionibus Sacri Supremi Regnii Aragonum Consilii, Lugduni, ex Typographia Hugonis Denoually

Diccionario de la lengua castellana (1729), en que se explica el verdadero sentido de las voces, su naturaleza y calidad, con las phrases o modos de hablar, los proverbios o refranes, y otras cosas convenientes al uso de la lengua, Madrid, Imprenta de Francisco del Hierro

Diego-Fernández, Rafael (2000), Una mirada comparativa sobre las Audiencias indianas, in: Mazín Gómez, Oscar (ed.), México en el mundo hispánico, II, Zamora, 517-553

Duve, Thomas (2004), La condición jurídica del indio y su condición como persona miserabilis en el Derecho Indiano, in: Losano, Mario (ed.), Un giudice e due leggi. Pluralismo normativo e conflitti agrari in Sud America, Milan, 3-33

Duve, Thомаs (2008), Sonderrecht in der Frühen Neuzeit. Studien zum ius singulare und den privilegia miserabilium personarum, senum und indorum in Alter und Neuer Welt, Frankfurt am Main

Elliot, John H. (2009), Introduction, in: Arrieta, Jon, John H. Elliott (eds.), Forms of union: the British and Spanish Monarchies in the Seventeenth and Eighteenth Centuries, Donostia

Escudero, José Antonio (2001), Los orígenes del Consejo de Ministros, I, Madrid

Fernández Albaladejo, Pablo (1992), Fragmentos de Monarquía, Madrid

Feros, Antonio (2005), "Spain and America: all is one." Historiography of the Conquest and Colonization of the Americas and National Mithology in Spain c. 1892 - c. 1992, in: Schmidt-Nowara, Christopher, John M. NietoPhilips, Interpreting Spanish Colonialism. Empires, Nations, and Legends, Alburquerque, 109-134

Ferro, Marc (dir.) (2003), Le livre noir du colonialisme. XVIe-XXIe siècle: de l'extermination à la repentance, Paris

Gaddis, John Lewis (2002), The Landscape of History: How Historians Map the Past, New York

Galán Lorda, Mercedes (ed.) (2012), Gobernar y administrar justicia: Navarra ante la incorporación a Castilla, Cizur Menor

Garavaglia, Juan Carlos (2004), La cuestión colonial, Nuevo Mundo Mundos Nuevos, Debates, Posted on 8 February 2005, URL: http://nuevomundo.revues. org/441

García Gallo, Alfonso (1946), La Constitución política de las Indias, Madrid 
García Pérez, Rafael D. (1998), El Consejo de Indias durante los reinos de Carlos III y Carlos IV, Pamplona

García Pérez, Rafael D. (2008), Antes leyes que reyes. Cultura jurídica y constitución política en la Edad Moderna (Navarra, 1512-1808) Milan

Garriga Acosta, Carlos (2002), Los límites del reformismo borbónico: a propósito de la administración de la justicia en Indias, in: Barrios, Feliciano (coord.), Derecho y administración pública en las Indias hispánicas, I, Cuenca, 781-821

Garriga Acosta, Carlos (2003), El derecho de prelación: en torno a la construcción jurídica de la identidad criolla, in: González Vale, Luis E. (coord.), XIII Congreso del Instituto Internacional de Historia del Derecho Indiano. San Juan, 21 al 25 de mayo de 2000. Estudios, II, San Juan, 1085-1128

Garriga Acosta, Carlos (2004), Orden jurídico y poder político en el Antiguo Régimen, in: Istor 16, 13-44 [online 1-21]

Garriga Acosta, Carlos (2006), Patrias criollas, plazas militares: sobre la América de Carlos IV, in: Martiré, Eduardo (ed.), La América de Carlos IV (Cuadernos de Investigaciones y Documentos, I), Buenos Aires, 35-130

Gerbi, Antonello (1973), The dispute of the new world: the history of a polemic: 1750-1900, Pittsburgh

Gómez Gómez, Margarita (1993), Forma y expedición del documento en la Secretaría de Estado y del Despacho de Indias, Sevilla

Gordillo, Gastón (2004), El colonialismo y los límites del relativismo: comentarios sobre "la cuestión colonial" de Annick Lempérière, Nuevo Mundo Mundos Nuevos, Debates, Posted on 8 February 2005, URL: http://nuevomundo. revues.org/439

Herzog, Tamar (2003), Defining Nations. Immigrants and Citizens in Early Modern Spain and Spanish America, New Haven

Herzog, Tamar (2004), Los americanos frente a la monarquía. El criollismo y la naturaleza española, in: Álvarez-Ossorio Alvariño/García García (2004) 77-92

Hinrichs, ERnest (1986), Giustizia contro amministrazione. Aspetti del conflitto politico interno al sistema della crisi dell'Ancien Regime, in: Capra, Carlo (ed.), La società francese dall'ancien régime alla Rivoluzione, Bologna, 199-227

Jellinek, Georg (1943), Teoría General del Estado, Buenos Aires

Konetzke, Richard (1962), Colección de documentos para la Historia de la Formación Social de Hispanoamérica, 1493-1810, vol. 3,2: 1780-1807, Madrid

Lempérière, Annick (2004a), La “cuestión colonial”, Nuevo Mundo Mundos Nuevos, Debates, Posted on 8 February 2005, URL: http://nuevomundo.revues. org/437

Lempérière, ANNICK (2004b), El paradigma colonial en la historiografía latinoamericanista, in: Istor 19, 107-128

LeVene, Ricardo (1951), Las Indias no eran colonias, Madrid

LYNCH, JoHn (1991), El siglo XVIII, Barcelona 
Mabel, Moraña, Carlos A. Jáuregui (2008), Revisiting the Colonial Question in Latin America, Madrid, Frankfurt am Main

Mannori, Lucca (1990), Per una preistoria della funzione amministrativa. Cultura giuridica e attività dei pubblici apparati nell'età del tardo diritto comune, in: Quaderni Fiorentini 19, 323-504

Manzano Manzano, Juan (1948), La incorporación de las Indias a la Corona de Castilla, Madrid

Muñoz Orán, Carlos E. (1960), Pronóstico de la independencia de América y un proyecto de monarquías en 1781, in: Revista de Historia de América 50, 439-473

Navarro García, Luis (1991), Hispanoamérica en el siglo XVIII, Sevilla

Navarro García, Luis (1995a), El falso Campillo y el reformismo borbónico, in: Temas americanistas 12, 10-31

Navarro García, Luis (1995b), Las reformas borbónicas en América. El plan de intendencias y su aplicación, Sevilla

Navarro García, Luis (1996), El Consejo de Castilla y su crítica de la política indiana en 1768, in: Homenaje al profesor García Gallo, III-2, Madrid, 187-207

Navarro García, Luis (1997), La crisis del reformismo borbónico bajo Carlos IV, in: Temas Americanistas 13, 14-23

Ortega, Francisco (2011), Colonia, nación y monarquía. El concepto de colonia y la cultura política de la independencia, in: Bonilla, Heraclio (ed.), La cuestión colonial, Bogotá, 109-134

Padgen, Anthony (2005), Lords of All the World: Ideologies of Empire in Spain, Britain and France, c. 1500 - c. 1800, New Haven

Pazos Pazos, María Luisa (1999), El ayuntamiento de la ciudad de México en el siglo XVII. Continuidad institucional y cambio social, Sevilla

Pérez Herrero, Pedro (2002), La América colonial (1492-1763). Política y sociedad, Madrid

Pérez Herrero, Pedro, Consuelo Naranjo Orovio, Joan Casanovas Codina (2008), La América española (1763-1898). Política y sociedad, Madrid

Pitts, Jennifer (2006), A Turn to Empire: The Rise of Imperial Liberalism in Britain and France, Princeton

Poloni-Simard, Jacques (2003), L'Amérique espagnole: une colonisation d'Ancien Regime, in: Ferro (2003) 180-207

Portillo, José María (2000), Revolución de Nación. Orígenes de la cultura constitucional en España (1780-1812), Madrid

Portillo, José María (2006), Crisis atlántica. Autonomía e independencia en la crisis de la monarquía hispánica, Madrid

Ramos Pérez, Demetrio (1959), Sobre la posible sustitución del término "época colonial", in: Boletín Americanista 1, 33-41

Ramos Pérez, Demetrio (1968), Los proyectos de independencia para América preparados por el rey Carlos IV, in: Revista de Indias 111-112, 85-123 
Ramos Pérez, Demetrio (1969), El problema de la fundación del Consejo de Indias, in: Anuario de estudios americanos 26, 385-425

Rivero Rodríguez, Manuel (2004), La preeminencia del Consejo de Italia y el sentimiento de la nación italiana, in: Álvarez-Ossorio/García García (2004) 505-528

Rodríguez, Mario (1976), La revolución americana de 1776 y el mundo hispánico, Madrid

Sallmann, Jean-Michel (2004), Les royaumes américains dans la Monarchie Catholique, Nuevo Mundo Mundos Nuevos, Debates, Posted on 8 February 2005, URL: http://nuevomundo.revues.org/431

Schäfer, Ernst (1935), El Consejo Real y Supremo de las Indias: Su historia, organización y labor administrativa hasta la terminación de la Casa de Austria, I, Sevilla

Sesé Alegre, José María (1994), El Consejo Real de Navarra en el siglo XVIII, Pamplona

Solórzano y Pereira, Juan de (1776), Memorial y discurso de las razones que se ofrecen para que el real y supremo Consejo de las Indias deba preceder en todos los actos públicos al que llaman de Flandes, in: Obras varias posthumas del doctor Juan de Solórzano Pereyra, Madrid, Imprenta Real de la Gaceta

Stiffoni, Giovanni (1989), Verità della storia e ragioni del potere nella Spagna del primo 700, Milan

Subrahmanyam, Sanjay (2004), Imperial and Colonial Encounters: Some Reflections, Nuevo Mundo Mundos Nuevos, Debates, Posted on 9 February 2005, URL: http://nuevomundo.revues.org/433

TAndeter, Enrique (1976), Sobre el análisis de la dominación colonial, in: Desarrollo económico. Revista de ciencias sociales 61, 151-160

Tau Anzoátegui, Víctor (2000), Las indias ¿provincias, reinos o colonias? A propósito del planteo de Zorraquín Becú, in: Revista de Historia del Derecho 28, $77-138$

Tau Anzoátegui, Víctor (2001), El poder de la costumbre: estudios sobre el derecho consuetudinario en América hispana hasta la emancipación, Buenos Aires

Torres López, Manuel (1926), El Estado visigótico, in: Anuario de Historia del Derecho Español III, 307-475

VAllejo, Jesús (2002), De sagrado arcano a constitución esencial. Identificación histórica del derecho patrio, in: Fernández Albaladejo, Pablo (ed.), Los Borbones: dinastía y memoria de nación en la España del siglo XVIII, Madrid, $423-484$

Ward, Bernardo (1779), Proyecto económico, Madrid, Imprenta de Joaquin Ibarra

Woseber, Gisela von (2003), Dominación colonial. La Consolidación de Vales Reales, 1804-1812, México

Wood, Gordon S. (2008), The Purpose of the Past. Reflections on the Uses of History, New York

Young, Robert J. C. (2001), Postcolonialism: an historical introduction, Oxford, Malden (Mass.) 
Zorraquín Becú, Ricardo (1974), La condición política de las Indias, in: Revista de Historia del Derecho 2, 285-380

Zorraquín Becú, Ricardo (1975), La condición política de las Indias, in: Memoria del Segundo Congreso Venezolano de Historia, Academia Nacional de la Historia, III, Caracas, 389-476

Zorraquín Becú, Ricardo (1988), Estudios de Historia del Derecho, I, Buenos Aires 



\section{Did European Law Turn American? Territory, Property and Rights in an Atlantic World}

\section{The Questions}

In 1648, analyzing the titles that Spain may have to the New World, Solórzano Pereira advanced the theory that these depended on its vassals first having "searched, found and occupied" the territory. Although the American continent was not truly a no man's land, Spain's entitlements, he insisted, were nevertheless guaranteed "because [its original inhabitants] abandoned it, leaving it uncultivated." Natural law and the law of nations, as well as the practice "in all the provinces of this world" instructed this abandoned land to be given to the Spaniards in reward for their "industry." ${ }^{1}$

Some forty years later, in 1690, in his "Two Treatises of Government," John Locke also sustained that property and industry were tied together. Those who cultivated a land that had been abandoned or was insufficiently worked, by mixing their labor with the earth created a new object to which

1 Solórzano Pereira (1972), book I, chapter IX, points 12 y 13. The original version reads: "y verdaderamente para las islas y tierras que hallaron por ocupar y poblar de otras gentes, o ya porque nunca antes las hubiesen habitado o porque si las habitaron se pasaron a otras y las dejaron incultas, no se puede negar que lo sea y de los más conocidos por el derecho natural y de todas las gentes, que dieron este premio a industria y quisieron que lo libre cediese a los que primero lo hallasen y ocupasen y así se fue practicando en todas las provincias del mundo, como a cada paso nos lo enseña Aristóteles, Cicerón, nuestros jurisconsultos y sus glosadores" and "los lugares desiertos e incultos quedan en la libertad natural y son del que primero los ocupa en premio de su industria." In the seventeenth century, "industria" was identified as "the diligence and easiness in which one does something with less work than others." With a comparative perspective in mind, it designated those who knew better and performed better: Covarruias Orozco (1995), 666. It is possible, however, that by the mid-eighteenth century it came to designate simply "a mastery or an ability in any art or profession:" Real Academia Española (1732), Diccionario de la lengua castellana, 258. 
they had now acquired title. ${ }^{2}$ This entitlement, Locke argued, harmed no one. After all, a land that had been abandoned or was insufficiently cultivated was a land that no one truly needed. Applying this theory to the Americas, Locke concluded that, because Native-Americans did not improve the land (nor did they mix their industry with it), they had no title to it, nor could they prohibit its occupation and use by others.

By 1758, both these theories were enshrined as doctrines of the Law of Nations (and thus of nascent international law). Emmer de Vattel, who had reproduced them in his recompilation, also insisted that cultivating the land was an obligation imposed upon man by nature, that all nations were bound by natural law to labor the territory that they occupied, and that those who did not "failed in their duty to themselves, injured their neighbors and deserved to be exterminated like wild beasts of prey." No one, he concluded, could "take to themselves more land than they have need of or can inhabit and cultivate," and no one "may complain if other more industrious nations, too confined at home, should come and occupy part of their land."

Most scholars have assumed that these developments marked an American addition to European (now also international) law. They pointed out that both Solórzano and Locke were deeply engaged in the "European Expansion," and both sought to legitimate what their countries were doing overseas. While Solórzano was a colonial judge working in Lima, Locke was a lawyer that, although living in the Old Continent, represented colonial interests. ${ }^{4}$ Vattel, who had made these theories part of a coherent body of law, may have had no commitment to colonialism per se, but his dedication to both philosophy and diplomacy geared him to search for a clear statement of what he thought was (or ought to be) the legal norms of his time. Scholars have also insisted that these developments demonstrated the contribution of the Americas to the consolidation of private property. It was first in the Americas, they sustained, that property was not only sanctified, but was also made a-historical. ${ }^{5}$

Part of a transatlantic conversation taking place in the seventeenth and eighteenth centuries, these conclusions serve here as an excuse to examine

2 John Locke, Two Treatises of Government, second treatise, chapter 5, points 27-51, especially points $31-32$.

3 Vattel (1916), book I, chapters VIII and XVIII, 37-38 and 85-86.

4 Arneil (1996) and Armitage (2004).

5 LARKIN (1969), 1-52. 
the relations between Early Modern European and American law. We already know that European law crossed the Atlantic and, in the process, also gained ground as an international law of sorts. We also know that it was constructed in a multilog between various actors working from different national traditions. But to what degree was this European law Americanized? Was there, indeed, a derecho indiano, as Spanish scholars have named the process of European law having gone native?

I suggest looking at these questions by observing both sides of the Ocean, centering not on how these theories had evolved, but instead on how some of their tenants were de facto implemented in both the Old and the New world.

\section{The Spanish-American Observatory}

Ideas linking use (mainly cultivation) to rights were clear in Spanish America as early as the sixteenth century, and they mainly operated to justify native dispossession. Although not necessarily codified in law books and regulations, they nevertheless found ample expression in court decisions that declared certain lands as occupied and thus belonging to the native inhabitants and others as vacant and thus open for colonization. The jurisdiction of the audiencia of Quito (present day Ecuador and southern Colombia) may serve as an example. Studying land litigation in Quito clarifies that, following royal instructions, Spanish judges were willing to recognize the right of native communities to the "land of their ancestors." ${ }^{6}$ However, they also authorized a gradual process that led to native dispossession, which historians have since lamented. ${ }^{7}$

As I have argued elsewhere in greater detail, recognition of ancestral rights did not guarantee continuity. ${ }^{\mathbf{8}}$ Instead, it introduced major changes in the way native rights were both defined and defended. The reason for this mutation was simple: Indigenous communities who wanted their right to land recognized by the Spaniards had to address the colonial courts. In Quito, at least, these courts responded to these claims by examining whether

6 Mariluz Urquijo (1978) 24-27. Also see Pagden (1986) and Adorno (2007).

7 Ots Capdequi (1959) 82 and 85 and González Rodríguez (1990) 171-198.

8 Herzog (2013) and (2014) 115-126. 
the land was indigenous according to Spanish criteria. ${ }^{9}$ Rather than being interested in reconstructing what had happened in the past, or what an Indigenous, pre-Colonial law- may have recognized and mandated, these judges affirmed, time and again, that the only test for the existence of rights was occupation. Rather than examining old entitlements, they proceeded to verify factors such as residence and continuous use. In most cases, they equated "use" with agricultural pursuits, both planting and pasturing. Gathering was sometimes also described as a legitimate activity giving rights to the territory. Hunting, on the contrary, never was. Spanish judges thus asked who was present on the land, what they were doing and not what title they held. They favored sedentary communities over others who used the territories in other ways and, subjecting rights to "actual use," they required that all natives continuously use the land, arguing that unless they did, territory could never be recognized as their own.

The accumulation of all these factors guaranteed that in the process of "recognizing indigenous right to land" the Spaniards profoundly transformed these rights; eliminating many that may have existed during the pre-colonial period, they created and gave others that were completely new. The judges, however, were only complementing what the king was doing too. During the colonial period, the Crown routinely distributed land to new or resettled indigenous communities. ${ }^{\mathbf{1 0}}$ Yet, in all these cases, land granted to natives was not considered their own. According to the law, this land was royal property (realengo) and it was to remain in native hands only

9 Documentation regarding land claims in the audiencia of Quito was mostly found in the National Archives of Ecuador/Quito (hereafter ANQ), sections titled cacicazgo, tierra, fondo especial, casas and gobierno. Additional documentation proceeds from the Spanish colonial archives in Seville (Archivo General de Indias, hereafter AGI) and the Biblioteca de la Real Academia de la Historia in Madrid (hereafter BRAH/M). See, for example, the questionaire submitted by don Juan Zumba cacique de Uyumbicho, Quito 28/8/1565, ANQ, Tierras 1 , exp. 1 de $14 / 8 / 1565$, fols. $12 \mathrm{r}-13 \mathrm{r}$ on $12 \mathrm{v}$ and the royal provision to the corregidor of Ríobamba, Quito, 16/8/1649, ANQ, Indígenas 16, exp. 2 de 2/9/1686, fols. $1 \mathrm{r}-4 \mathrm{r}$, on fol. $2 \mathrm{r}$.

10 Herzog (2007). For an older bibliography on these issues see Málaga Medina (1974) and Solano (1976). On its functioning in Quito see petition of Andrés Zumbaña in ANQ, Tierras 1, exp.1 de 14/8/1565, fols. 18r. The grant of land to Indians on the occasion of their resettlement (reducción) was also mentioned in the petition of the protector de naturales of Cuenca, ANQ Tierras 17 exp. 19/6/1692. 
as long as natives needed it for their survival and tax payment. ${ }^{11}$ If they no longer did (and the best proof that they did not would be insufficient use), the territory would revert to the Crown and could be redistributed to those who would allegedly use it better. Subjected to a "right of return" (derecho de reversión) in case of non-use (or insufficient use), all land granted to indigenous communities was thus conditional. Under continuous scrutiny, the Spaniards - both litigants and judges - periodically questioned whether the original grant was justified and whether, at the present, the community still needed the land. Extremely powerful during the periodical examination of land titles called composiciones, the tying of rights to (sufficient) use, became the most powerful mechanism of native dispossession. ${ }^{\mathbf{1 2}}$ Echoing what Solórzano, Locke and Vattel had described, it mandated a new moral economy according to which land should be the property not of those who had it first but instead of those who could work and use it better.

The legal reasoning that Solórzano, Locke, Vattel, and the judges of Quito followed to justify the dispossession of Indigenous peoples by arguing their neglect to work the land sufficiently could also operate vis-à-vis European powers. This was clearly the case in the Spanish-Portuguese borderland in the American interior. Although the Spaniards and Portuguese invoked papal bulls and bilateral treaties in their relationship with one another, the historical documentation generated on the border itself demonstrates that both parties were mostly obsessed with the question who was where and what they were doing. ${ }^{13}$ Discovery and exploration - that is, the initial and early arrival to the territory - were important in such discussions regarding land

11 Petition of the protector de indios, Quito 9/11/1791, ANQ, Cacicazgo 3, exp. 3 de 9/11/ 1791, fol. 3r, ANQ, Indígenas 1, exp. 3 de 13/12/1597 and "provisión real a petición del protector general en nombre de Antonio Amaguano cacique de Nayon," ANQ cacicazgo 44, vol. 99, 23/2/1732, fol. 3r-v. The particular status of such lands was described in Solórzano Pereira (1972) 379-380.

12 Latin American composiciones were studied by many. See, for example, Torales Pacheco (1990) and Amado González (1998). Also see Recopilación de Indias, book 4, title 12, laws 15-21. Their operation vis-à-vis native communities was exemplified in petition of Salvador Ango Pilainlade Salazar cacique, Otavalo, 3/12/1692, ANQ, Tierras 18 exp. 15/12/ 1692, fol. 1v. and petition of Juan Guaytara, cacique, Quito, 15/3/1712, ANQ, Tierras 34, exp. 15/3/1712, fols. $2 \mathrm{r}-\mathrm{v}$.

13 These issues are analyzed in greater length in Herzog (2014). 
rights, but much more crucial than the question of who had arrived first was who had remained: who had established a permanent settlement, or had used the territory continuously for transit, commerce, the gathering of fruits, and so forth. ${ }^{14}$ As a result, rather than discussing where the border between Spain and Portugal passed, the inhabitants of both powers were engaged in proving what they already possessed and occupied. They sent their respective monarchs reports about their progress, and they "authenticated" (autenticar) their claims by conducting judicial investigations and collecting oral declarations. ${ }^{15}$

Because rights depended on acutal use of the land, the territorial possession that resulted was often discontinuous. Made of fields, farms, woods or settlements, entitlements took the form of an archipelago, with "islands" of occupation and use surrounded by a "sea" of "unoccupied land", as well as corridors and routes connecting them. ${ }^{16}$ And, while the territory in between occupied parcels was open for appropriation, how to define the islands already used became a major concern. The nucleated nature of the territory that the Spaniards and the Portuguese both possessed came into focus, for example, during discussions involving Colonia de Sacramento (in present day Uruguay). Colonia was built, destroyed, rebuilt, taken again, and returned once more, on several occasions during the late seventeenth and eighteenth centuries. While discussants in Europe referred to it as a solid, clear unit, this clarity dissipated in the Americas. What did Colonia consist of? Was it equal to the territory of its fort? Did it include all of the hinterland that its soldiers and residents occupied? And, if so, should not this

14 A letter of the Count of Bobadilla to Pedro Cevallos, Rio de Janeiro 29/2/1762, Archivo General de la Nación/Buenos Aires (hereafter AGN/BA), IX.4.3.5 and a letter of Domingo Ortiz de Rosas to Antonio Pedro de Vasconcelos, undated, although describing events taking place in 1743, Archivo General de la Nación in Montevideo (hereafter AGN/M), Archivos particulares, Caja 333, Colección de documentos de Mario Falcao Espalter, carpeta 3, titled "Documentos relativos a las luchas entre España y Portugal por la posesión de la banda oriental y proceso de población de dicho territorio," 1685-1757.

15 "Auto de inquirição de testemunhas para justificação da posse e domínio do rio Branco pela coroa de Portugal," 1775, attached to ofício do gobernador e capitão geral do estado do Pará e Rio Negro João Pereira Caldas para o secretario de estado da marinha e ultramar Martinho de Melo y Castro, Pará, 4/1/1776, Archivo Histórico Ultramarino, Lisboa (hereafter AHU), acl_cu_013, cx.74, d.6261.

16 Herzog (2002) and Garavaglia (2003). 
territory be defined by a judicial investigation that would prove what they had truly occupied and what not? ${ }^{17}$

Because occupation and use mattered even on the international scene, individuals and authorities on the ground had to be both extremely active and extremely vigilant. They had to ensure that the territory they pretended was theirs would be constantly used and re-used; but they also had to certify that their rivals shied away from it, as well as from any new area. If the rivals did not, expressing protest was crucial because the lack of a response could be legally constructed and comprehended (by way of legal presumption) as consent.

Conflict regarding use, however, was not limited to land. Both the Spaniards and the Portuguese understood that controlling the local population was a means to control the territory. Distinguishing natives according to their degree of hostility to them and their potential for "domestication," Europeans also classified them according to whether they were "inclined" to one country or the other. ${ }^{18}$ In the process, natives, too, became objects to be possessed (or "used"). Not only did Europeans try to convert those who were their enemies into their allies or ensure (when they failed) their annihilation, they were also constantly suspicious of what their native "friends" may do. ${ }^{19}$ They believed that those who had reached an "understanding" with them could turn into foes and ally with their rivals. From a Spanish

17 "Apuntamiento de secretaría ejecutado en cumplimiento del acuerdo del consejo de 20.6. pasado ...", Madrid, 4.7.1716, AGI, Charcas, 263. The question of how defining the jurisdiction of Colonia affected the borders of Brazil was asked, for example, in 1713: "Parecer do Marquês de Frontera sorbe a paz com Castela," Lisbon 31.7.1713, cited in RAU/Gomes DA Silva (1955), V. 2, no. 177, p. 120.

18 “Instrução da Rainha para D. Antonio Rolim de Moura," Lisbon, 19.1.1749, Arquivo Público de Mato Grosso (hereby APMG), Livro C - 03, Doc. 01, fols. 3-8, fol. 5, point 16 and "Carta do governador e capitão-general da capitania de São Paulo Rodrigo César de Meneses para o governador e capitão-general da capitania do Rio de Janeiro Aires de Saldanha ...," São Paulo, 15.3.1724, AHU, ACL_CU_023-01, Cx. 3, D. 374. I would like to thank João Antonio Botelho Lucidio for sending me the information from Mato Grosso.

19 "Tratados que deberán observar con este superior gobierno el cacique Callfilqui a consecuencia de lo que ha estipulado ... con el," AGN/BA, Biblioteca Nacional 189 exp. 1877. The bibliography on treaties with Indigenous groups have become especially abundant in recent years: LeVAgGi (2000); Levaggi (2002); Néspolo (2004) and Lázaro Ávila (1999). We are thus now a long way away from the affirmation made by Charles Gibson in 1978 according to which such peace treaties were absent in Spanish America: Gibson (1978). 
perspective, this apprehension was tied to the belief that the Portuguese were willing to appease the natives in ways the Spaniards were incapable of doing, offering them expansive and frequent gifts or promising them a better treatment. ${ }^{20}$ The Spaniards thus reminded "their" Indians of their obligation to them. The Portuguese did the same. ${ }^{21}$ Complaining that "vassals of Spain" convinced Indians inclined to their friendship to attack them, they circulated rumors that indicated that several such natives might have even joined the Spaniards in the effort to expel the Portuguese. ${ }^{\mathbf{2 2}}$

In the process, the inhabitants of both powers portrayed Indian allies as their property. ${ }^{23}$ Perhaps not quite "theirs" as the land was considered to be, but not so drastically different; these Indians, they argued, were already in their "possession"(sic) and could therefore not become the property of another. These beliefs led the Spaniards to complain in the 1770s, 1780s and 1790s, that the Portuguese "stole" (robar) "their" Indians. ${ }^{24}$ Calling these activities "piracy", they insisted that the Portuguese invaded native villages belonging to Spain, capturing their inhabitants and removing them, sometimes in bulk, but always violently, to Portuguese territories. The natives

20 "Memorial del padre Cristóbal de Acuña sobre el descubrimiento del rio de las Amazonas, 1639," AGI, Quito 158, fol. 3v and a letter of Lázaro de Ribera to the viceroy of Buenos Aires, Asunción, 18/9/1797, AGI, Estado 81, No. 15 (1e).

21 "Consulta do Conselho Ultramarino referente a uma carta do governador e capitão-general da capitania de São Paulo Conde de Sarzedas ao rei informando êste monarca do perigo da perda de Cuiabá ..., Lisbon, 5/5/1733, AHU, ACL_CU_023-01, Cx. 8, D. 899.

22 "Representção dos oficiais da Câmara de Curitiba ao rei pedindo-lhe que aquela vila fosse assistida pela provedoria da praça de Santos ...," Vila Real de (Curitiba), 2/9/1744, AHU, ACL_CU_023-01, Cx. 15, D. 1491 and "Noticias dadas por huma copia en 1/4/1775," attached to "Ofício do governador de Iguatemi José Custódio de Sá e Faria ao governador de São Paulo Martinho Lopes de Saldanha," Iguatemy, 20/7/1775, AHU, ACL_ CU_023-01, Cx. 30, D. 2707.

23 A letter of Joaquim Tinoco Valente to the governador of Pará, Barcelos, 20/7/1765, Arquivo Provincial Esatdo do Pará, Belém do Pará (hereafter APEP), Cod. 155, Doc. 41 and a letter of Pedro Domínguez to Jose de Espinola, Fuerte Borbón, 20/7/1797, Archivo Histórico Nacional, Madrid (hereafter AHN), Estado 3410, No. 13. I would like to thank Heather Flynn Roller for sending me documents from Para.

24 The interrogatory elaborated by Juan Francisco Gómez de Villasufre y de Arce, governor of San Joaquin de Omagua on 26/5/1775 and the declarations that followed it, ANQ, Fondo Especial 30, vol. 83, no. 3226, copy of letters by Francisco Requena to Antonio Caballero y Góngora dated 20/8/1783 and 8/10/1783, AHN, Estado 4677-1, No. 5 and a letter of Felipe de Arachua y Sarmiento to Francisco Requena, 15/7/1783, AHN, Estado 4611. 
captured in this way by the Portuguese, the Spaniards argued, belonged to "nations friendly with Spaniards" (afectas a España), were already conquered by Spain (conquistados por España), were vassals of the Crown, or were outright Spaniards. If they allowed the Portuguese to take them without issuing a protest, as would happen with territory, the Portuguese would become proprietors of all the land. ${ }^{25}$ Responding to these allegations, the Portuguese normally attested that the Indians were not extracted by force but instead willfully came to live among them. ${ }^{\mathbf{2 6}}$ Nonetheless, Portuguese documentation clarifies that the Portuguese actively engaged in campaigns to transform Indians favorable to Spain (or, according to Spanish versions, already in Spanish possession) into allies of Portugal. They also apprehended, or gave refuge, to natives who abandoned Spanish missions and arrived at Portuguese territories. ${ }^{27}$ Records also indicate that in order to influence these natives, the Portuguese may have offered them gifts and a better treatment. Indians may have been told that the Spaniards wished to kill them and that they habitually maltreated the indigenous population. ${ }^{28}$ It is also possible that, on occasion, natives were threatened that either they willfully submitted or they would be forced to. ${ }^{29}$

Although bitterly resenting the Portuguese, the Spaniards may have used similar strategies. Already in 1697 , the Portuguese governor of Maranhão

25 Joaquín Alos, governor of Paraguay to viceroy Nicholás Arrendondo, Asunción, 19/9/ 1791, AHN, Estado 4387, No. 5.

26 The original version reads: "como sean los referidos indios personas libres, pues los contempla así la santa sede apostólica y los mismos soberanos a cuyos dominios pertenecen, pueden usar de su libertad que les da facultad como señores de ella mayormente para que usen de ella con sosiego a donde les pareciere sin ninguna sujeción de esclavos como en cierto modo los quiere vuestra merced ...” Feliz José Souza to Francisco José Texeira, Fuerte el Príncipe de la Vera 23/11/1784, AHN, Estado 4436, no. 10.

27 "Ofício do governador e capitão geral da capitania de Mato Grosso Luís de Alburquerque de Melo Pereira e Cáceres ao secretário de estado dos negócios do reino Marquês de Pombal,' Vila bela, 8/1/1777, AHU, ACL_CU_010, cx. 18, d. 1146.

28 A letter of Pedro de Cevallos to Ricardo Wall, ministry of State, San Borja 7/12/1757, reproduced in Campaña del Brasil. Antecedentes coloniales, Buenos Aires 1939, vol. II, $245-6$ on page 245 .

29 Copy of a letter of Joseph García de León y Pizarro a Antonio Caballero y Góngora 18/4/ 1784, AHN, Estado 4677-1, No. 5 and a letter of Juan Joseph de Villalengua, president of the audiencia of Quito to José de Gálvez, Quito, 18/6/1784, AHN, Estado 4677-1, No. 7. Also see letters of Lázaro de Ribera to viceroy Antonio Olaguer Feliú, Asunción, dated 18/ 9/1797 and 24/3/1798, AHN, Estado 3410, No. 13. 
complained that Jesuits may have convinced Indians living in Portuguese aldeias to move to their (Spanish) missions. Affirming that these Indians were Portuguese vassals living on Portuguese territory and in Portuguese (Carmelite) missions, the Portuguese Overseas Council ordered this stopped. ${ }^{\mathbf{3 0}}$ The Jesuit explanation that these Indians chose to come to the mission of their own free will was (of course) rejected. ${ }^{31}$ Portuguese complaints of Spanish attempts to remove Indians from their territories continued into the eighteenth century, intensifying as the century progressed. By the 1750s, the Portuguese accused the Spaniards of convincing Indians who "were inclined favorably to Portugal" to ally with Castile by suggesting to them that the Portuguese would make them slaves. ${ }^{32}$ According to other sources, in the 1760 s, the Spaniards encouraged "Portuguese" Indians to rebel. $^{33}$

Indians could thus maintain their lands only if they continuously used it, and Europeans could make claims to territory and people only if they constantly occupied and controlled them. This was a world in turmoil, in which no right seemed permanent, and no success ever guaranteed. But were these developments a particularly American phenomenon, or were they also present in Europe?

\section{The European Observatory}

The relationship between use and rights had, of course, European roots. Greek and Roman writers were already unanimous in holding that property was a man-made institution that had emerged as a consequence of the adoption of agriculture. According to them, while hunters had no property, pastoralists had owned their animals and farmers developed property in

30 "Consulta do conselho ultramarino para o rei sobre o missionário jesuita castelhano padre Samuel," Lisbon, 12/11/1697, AHU, acl_cu_013, cx. 4, d. 340.

31 Rodríguez Castello (ed.) (1997) 131 and 133.

32 A letter of Councilor Tomé Joaquim da Costa Corte Real to Antonio Rolim de Moura, governor of Mato Grosso, Lisbon, 7/7/1757, APMG, CMG-SG, Livro C-18, Estante-01, letter 1 , fols. $9-17 \mathrm{v}$.

33 A letter of Valerio Correa Botelho de Andrade, interim governor of Rio Negro to Manoel Bernardo de Mello e Castro governor of Grão Pará, Barcelos, 22/12/1762, APEP, Cod. 99, Doc. 94, 1R. 
land. ${ }^{34}$ Most medieval and early modern authors seemed to agree. ${ }^{35}$ Many pointed out that God gave man the land so that he could fulfill his needs and that, as a result, all property in land was conditioned by proper use. Making the cultivation of the land also a religious duty, they insisted that property was supposed to advance, not diminish, public utility. In Spain, these visions were dominant during the Reconquista, allowing individuals and communities to obtain title to land, which others had allegedly abandoned or insufficiently worked. ${ }^{36}$ They were also continuously invoked in the sixteenth and seventeenth century by arbitristas who insisted on the obligation of kings to reward those who cultivated the land by giving them title to it, and to punish those who did not by forcing them to either use the land or surrender it. ${ }^{37}$

The clearest example of how in early modern Spain, too, use and rights were closely related is that of the repopulation campaigns carried out in the seventeenth and eighteenth centuries. ${ }^{38}$ These campaigns, which identified the depopulation of the country as one of the major reasons for its economic decline, advocated the need to use vacant territories (despoblados) and, above all, to resettle those places that were once cultivated. In the eyes of many, these depopulated areas incarnated Spain's problems. Having once been "useful," they became "waste". To reverse these tendencies, royal action was necessary. The king had to force those who possessed despoblados to cultivate them or allow others to do so.

Repopulation campaigns, particularly prominent in the late seventeenth and eighteenth centuries, caused major social upheaval. ${ }^{39}$ While those who wanted access to land pressured royal delegates to translate royal orders into

34 Roman law may have authorized the seizure of uncultivated land (agri deserti) in order to guarantee that it would be worked and taxes would be paid on them: Concha Y MARTínez (1946) 139-144. The theory linking property to agriculture survives to date: Dodgshon (1987), 24-71.

35 Tully (1980) 65-69, 80 and 100, Rodríguez Puerto (1996-1997) 495-503 and 510-525, on 499-500 and 518 and Pagden (1998) 172.

36 Concha y Martínez (1946).

37 Niehaus (1976); Rodríguez (1984); Maravall (1972), vol. 2, 325-339 and Vassberg (1974) 384-385 and 393-394.

38 Palacio Atard (1989); Oliveras Smitier (1998) and Helguera Quijada (1995).

39 Archival documentation regarding these resettlement campaigns is mainly located at the $\mathrm{AHN}$, Consejos, although some of it is also reproduced in municipal and provincial archives, as well as the archives of royal courts, and the Royal Academy of History. 
action, those who possessed land often refused to collaborate. As a result, repopulation campaigns often degenerated into long discussions involving municipalities, proprietors and hopeful colonists. At stake were classificatory questions, mainly, which territories were depopulated or insufficiently used. Also debated was what was the land's true potential and who was best suited to pursue its improvement. Given these conditions, seventeenth- and eighteenth-century repopulation campaigns are a good starting point for understanding the relationship, in Peninsular Spain between land and use, use and rights.

Repopulation campaigns made two issues clear. First, most individuals and groups who requested permission to cultivate a territory, which they considered empty or insufficiently used, usually argued that pasture, when arable agriculture was possible, was a waste. ${ }^{40}$ According to them, grazing did not improve the land, nor did it ensure that its potential would be met. Land dedicated to pasture was not only wasteful, it was also dangerous. Uncultivated and left in a state of nature, it served as refuge for dangerous people and wild animals, even disease. ${ }^{41}$ Leaving land in this barren state, they argued, was never an informed decision. On the contrary, it was mainly due to neglect, willful and at times even criminal. ${ }^{\mathbf{4 2}}$

If the first point of almost general agreement was criticism of grazing, the second was the allegation that improving the land by making it achieve its (true) potential was not a choice but an obligation. Tying the reform of land to the reform of its people, improvement would ensure that, through access to land, poor vagabonds would be transformed into responsible, law-abiding individuals. ${ }^{43}$ Improvement would also guarantee the domestication of nature itself: uncultivated land became arid to the point of no return. ${ }^{\mathbf{4 4}}$

40 AHN, Consejos 4057, fol. 1r-4r and 6r.

41 The report written by Pablo de Olavide, Seville, 20/11/1773, AHN, Consejos 4048, fols. 6r-9r and AHN, Consejos 4061, no. 15, fols. 30r-36r.

42 Contemporary documentation does clarify, however, that some fields may have been abandoned as a result of the "difficulties of the time," epidemic outbreaks, or foreign occupation: AHN, Consejos 4047 and petition of the "lugares de las valles de Broto y Tena ..." undated, Biblioteca Nacional, Madrid (hereafter BNE) VE/200/11.

43 Petition of Manuel Rodríguez, Madrid, 23/11/1798, AHN, Consejos 4061 n. 2 and AHN, Consejos 4061 n. 13, fols. 6r-9r.

44 Arriquibar (1779) 238-239 and la Real Sociedad Matritense de Amigos del País en 1780 according to: Archives of the Real Sociedad Matritense de Amigos del País (hereafter RSMAP) 37/1. 
Cultivating the land was deemed a patriotic activity as the re-conquest of barren terrain, some argued, was "more glorious, useful and secure than the conquest of distant lands." ${ }^{5}$

Who was best suited to reform the land was another debated issue. Landlords tended to argue that the poor certainly were not. After all, even if they did not lack experience as laborers, they certainly lacked the knowledge, the means and the tools necessary to improve the land. ${ }^{46}$ Settlers who were "refugees and beggars" (prófugos y mendigos) were equally unsuitable. ${ }^{47} \mathrm{Col}-$ onizers, therefore, should be of adequate age, economic stature and education. ${ }^{48}$ In short, intention to improve the land was perhaps a necessary but certainly not a sufficient condition. Furthermore, those wishing to become colonizers were to have a true "vocation." They would have to have a true interest in improving the land (not only in acquiring possession of it), and they would also have to prove that they were capable of carrying out what they promised. ${ }^{49}$

Although repopulation campaigns did not always involve property rights - in many campaigns colonists would have to pay fees to landlords, who would maintain their property -, on most occasions, (proper) use was to lead (eventually) to rights. One popular way to attract colonists, for example, was precisely the promise to transfer land rights after a certain period. Without such an outlook, it was feared, nothing would be achieved. ${ }^{50}$ And, if improvement gave title to land - if not immediately, at least eventually -, the

45 The original version reads: "un reino podría formarse de sólo estos desiertos espantosos y su reconquista sería más gloriosa, útil y segura, que la de países distantes:” ArriQuibar (1779) 235. Also see: Joaquín Navarros, Plan de repoblación para el lugar de Zarapuz en el reino de Navarra, 1778, RSMAP 25/11.

46 "Informe del alcalde mayor Antonio Joseph Cortés", 26/2/1783 and 19/5/1783, AHN, Consejo $40841 \mathrm{r}-4 \mathrm{r}$ and $12 \mathrm{r}-13 \mathrm{r}$.

47 Alegations of the villa de Melgar de Fernamental in Real Chancillería de Valladolid (hereafter RCV), Pleitos Civiles, La puerta 2153/1.

48 Petition of Cristóbal García de Cantos of 1798 and the conclusions of the junta in on 1/ 10/1798, AHN, Consejos 4061, cuaderno 8 and "real provisión en que se contiene en fuero de población de la Nueva Villa de Encinas del Príncipe ...” 1779, AHN, Consejos 4084.

49 Petition of Cáceres and su jurisdiction, 31/5/1800, AHN, Consejos 4060, expediente de Cayo Joseph López.

50 "Los colonos destinados al despoblado de Peñacerracín," 26/7/1788, AHN, Consejos 4088, and "Real resolución," Madrid, 15/3/1791, ANH, Consejos 4088. 
opposite was also true: landlords who refused to cultivate their land could lose not only their possession, but also their property rights. This could happen, contemporaries argued, because owners who did not cultivate their land had no rights at all. After all, they received the land under the condition that they would use it, and their failure to do so was sufficient to justify repossession and redistribution of the land. In the words of a contemporary observer: "For centuries, these lands have been fruitless. Their owners did not have, nor have at the present, nor can have in them any utility other than what they could have in possessions situated in imaginary spaces." ${ }^{51}$ What was also helpful was the conviction that, on these occasions, the king could intervene in the existing legal order and both relinquish and create rights. This, it was argued, was the meaning of sovereignty: the king's superior and eminent domain over all the land allowed him to distribute it according to public need, denying certain (existing) privileges and creating others anew.

Given this background, it is not surprising that, by the eighteenth century, like Solórzano, Locke and Vattel, Spanish authors also identified work with property. ${ }^{52}$ They argued that labor, rather than land, produced riches and they reasoned that progress required allowing individuals to profit from the fruits of their labor. However, Spain was not the only European country in which these issues played a major role during the seventeenth and eighteenth centuries. England, where Locke wrote his essays, is another example.

From as early as the sixteenth century and more clearly in the three following centuries, the English countryside underwent a profound transformation. ${ }^{53}$ Although historians have disagreed about its origin, development and results, they have all coincided that during this period many lands previously considered public were made private through a process that they termed "enclosure." According to them, economic pressures led to the fencing of lands, on the one hand, which demanded a more efficient usage, on the other. ${ }^{54}$ Contemporary, was a new ideology that connected property to

51 The original version reads: "pues ni han tenido ni tienen ni pueden tener por el orden regular en ellas más utilidad, que lo que pudieran figurarse en unas posesiones situadas en los espacios imaginarios." ArriQuibar (1779) 236.

52 Jovellanos (1795) 8 and 12-13.

53 S Later (1907) and Tawney (1965).

54 This mixing of elements eventually allowed authors such as Grotius and Locke to consider the lack of enclosure a sign of absence of improvement and thus the lack of title or property: ArNeIL (1996) 62. 
improvement, arguing that only those sufficiently knowledgeable and capable of making the land truly profitable should be allowed to hold it. Tied to the commercialization of agriculture and to a general attack on both public and communal land-holding (making private property a social and political ideal), these processes led to the dispossession of many individuals, families and communities, converting them from small peasants into landless agricultural (and eventually industrial) wage workers.

Although these developments gradually gained strength, until the eighteenth century enclosure, at least, it was a controversial measure that many criticized. ${ }^{55}$ They debated its political, economic, social and legal wisdom and asked whether it was beneficial, to whom, and to what extent. Defenders of these policies insisted that they guaranteed the "common good" because they supplied the country with more food (the assumption was that fields better used would produce more) but also because they would reform the peasant and the poor, leading the country from "backwardness" to "modernity." Identifying enclosure and the privatization of land with its "improvement," such actors sustained that this was the only means of encouraging investment and innovation. Labor was central to this debate as it was assumed that the state of agriculture depended on human action, not natural conditions. ${ }^{56}$ Portrayed as an activity confronting man with nature rather than with other men, improvement (and the subsequent appropriation it entailed) were thus considered a heroic struggle against territories - for example, grazing grounds - still in a "state of nature." 57 By the end of this process, the call to improve the land was couched as a religious duty to transform chaotic nature into a domesticated garden.

The argument supporting enclosure and improvement justified the transfer of property from those "unworthy" to those who would use it "correctly." Yet, if in theory, it could undermine not only the rights of communities to their common lands and the poor to their own, but also endanger the entitlements of wealthy landowners who did not use their properties sufficiently, such was not the case. ${ }^{58}$ As happened in the Americas, in practice, this powerful discourse was mainly applied to some sectors and to them

55 NeEson (1993).

56 ARNEIL (1996) 96-103.

57 Larkin (1969) 1-2 and Brace (1998) 161-162.

58 WeAVER (2004) 80-82. 
alone. It was as if the inherent assumption - almost never questioned - was that collective and poor was the same as bad use, whereas individualistic and wealthy equaled good. These presumptions allowed continuous scrutinizing and criticizing of the first, yet no real attempt to measure the performance of the second. Put differently, rather than being based on a case-to-case analysis (as the theory may have suggested), asking in each case what was the true potential of each section of land and how it could be improved and by whom, certain stereotypes supplied an automatic response that while undermining the rights of certain sectors, defended those of others.

By the eighteenth century, the literature that criticized the English poor and English communities for insufficiently attending to their land compared the members of these European groups to Native- Americans. Sometimes implicitly, others explicitly, it argued that it made equal sense to dispossess one and the other. ${ }^{59}$ After all, both the English poor and the American Indians were "backward", and both hindered "progress." It is also possible that practices in England informed behavior in the colonies. Not only because enclosure and improvement were first used in Ireland against the local inhabitants, not only because John Locke may have been inspired by developments in the Old World in order to elaborate his theories regarding the colonies, but mainly because there is evidence that English peasants who experienced dispossession at home ended up replicating it vis-à-vis natives, whose property they coveted and whom they could accuse of insufficiently working the land. ${ }^{60}$

\section{Conclusions}

In the Americas as in Europe, by the late sixteenth century and clearly in the seventeenth and eighteenth centuries, the right to land was tied to its "proper use." What proper use meant could be endlessly debated, but it was clearly the case that in both England and Spain, as well as in the Old and the New

59 Neeson (1993) 30 and Brace (2001) 16-17. According to Brace (1998) 164, "The virtuous disciplined improver was defined not only in contrast to the property-less and wasteful hunter-gatherer in America, but also as directly opposed to the ungodly, undisciplined and unemployed in England." On how improvement became an imperial policy see Drayton (2000).

60 Buck (2001) 47. 
World, these adjectives were mostly applied generically to certain activities of certain people, who were stereotyped as wasteful or, at least, not as sufficiently active or informed as to transform "deserts" into fertile gardens. ${ }^{\mathbf{6 1}}$ The road leading from criticism to criminalization was short but meaningful. By the end of this process, not only were some Native- American and Europeans dispossessed, but this dispossession was presented as their own fault. It was a punishment of sorts for their own neglect, a means to force them to improve their ways and become "modern."

Although commonalities existed, so did differences. Improvement was seen as an individualistic endeavor in England; in Spain and overseas it had stronger communal overtones as many believed that it would only happen through the formation of new or the conservation of old communities. Yet, despite these differences, and the fact that property was not always immediately transformed in Spain, eventually in all three places (England, Spain, and Spanish America) indigenous communal property ended up in the hands of individual outsiders.

One feature that tied all these questions together was the constant debate unleashed on both sides of the Ocean on how to reorganize land regimes in ways that seemed more "reasonable" to contemporaries. Whether "reasonableness" was the motive or the excuse we will never know - it is probable that both were equally present - but, regardless, it is clear that rather than debating titles and historical rights, what contemporaries did was to discuss how to change them, how to undermine them, or how to relinquish them altogether. It was as if they were willing to reinvent the social contract and the legal basis for ownership by putting a new spin on existing theories. This was an important development within a society (still) marked by tradition and in which, for centuries, the right to land depended on the passage of time. Now, instead of "historical rights" what mattered was a certain "public utility." Historical amnesia, in short, was equally present on both sides of the Ocean, although its results may have differed according to place and time. Tabula rasa was not an American invention; it was tied to a process we now identify as "modernity"

61 It is thus debatable whether England had indeed developed a particular discourse that, contrary to other European nations, focused "on the possession of territory to the exclusion of its inhabitants" and had passed from judging ownership and cohabitation to evaluating use: TomLIns (2010) 132-134. 
Insistence on the present rather than the past, however, may have been particularly useful in the Americas, as it allowed ignoring the rights of previous occupiers; nonetheless, it was also powerful in Europe. Tied to the growing notion of sovereignty and royal responsibility, it imagined a modernizing upper class leading the rest of humanity (mainly indigenous peoples and the poor) to "progress." Rather than Americanized, law was modernized. The Americas, in short, may have accentuated European debates on what occupation and proper usage were, but they did not invent them, nor did they clearly depart from existing notions as experimentation took place on both sides of the Ocean contemporaneously.

The inability to distinguish European from American developments was one feature of this modernization process. Although some institutions, laws and doctrines found a more fertile ground on one side of the Atlantic versus the other, the constant dialog between both and the continuous influx of ideas and practices made these worlds to some degree united. Practices experimented in Europe were implemented in the Americas, while also influencing the Old World. Success or failure in one could be detrimental to the experiment on the other side, but exact genealogies are hard, perhaps even impossible, to establish. On certain occasions, the Americas appeared almost as a platform on which ideas about Europe were debated. On others, it was a cause and a reason to reconsider old truths. But whatever the precise dynamics may have been, this continuous conversation ensured that the law constantly changed. Under the guise of continuity, it mutates according to place, time and circumstances. ${ }^{\mathbf{6}}$ And, although innovations could be the result of an encounter with new circumstances, more often than not and as usually happens with law and legal change, they included new visions and new ways of interpreting the existing canon.

62 Mariluz Urquijo (1976) 389-402.

92 Tamar Herzog 


\section{Bibliography}

Adorno, Rolena (2007), The Polemics of Possession in Spanish American narrative, New Haven

Amado González, Donato (1998), Reparto de tierras indígenas y la primera visita y composición general, 1591-1595, in: Histórica 22,2, 197-207

Armitage, David (2004), John Locke, Carolina and the Two Treatises of Government, in: Political Theory 32,5, 602-627

Arneil, Barbara (1996), John Locke and America. The Defense of English Colonialism, Oxford

Arriquibar, Nicolás de (1779), Recreación política. Reflexiones sobre el amigo de los hombres en su tratado de población considerando con respecto de nuestros intereses, Vitoria

Brace, Laura (1998), The Idea of Property in Seventeenth-Century England. Tithes and the Individual, Manchester

Brace, Laura (2001), Husbanding the Earth and Hedging out the Poor, in: Buck / MClaren/Wright (2001) 5-18

Buck, A. R. (2001), 'Strangers in Their Own Land:' Capitalism, Dispossession and the Law, in: Buck/Mclaren/ Wright (2001) 39-56

Buck, A. R., John Mclaren, Nancy E. Wright (eds.), Land and Freedom. Law, Property Rights and the British Diaspora, Aldershot

Concha y Martínez, Ignacio de la (1946), La “presura." La ocupación de tierras en los primeros siglos de la reconquista, Madrid

Covarruias Orozco, Sebastián de (1995), Tesoro de la lengua castellana o española (1611), ed. Felipe C. R. Maldonado, Madrid

Dodgshon, Robert A. (1987), The European Past. Social Evolution and Spatial Order, London

Drayton, Richard (2000), Nature's Government. Science, Imperial Britain and the 'Improvement' of the World, New Haven and London

Garavaglia, Juan Carlos (2003), Frontières des Amériques ibériques, in: Annales HSS 58,5, 1041-1048

Gibson, Charles (1978), Conquest, Capitulation, and Indian Treaties, in: The American Historical Review 83/1, 1-15

González Rodríguez, Adolfo Luis (1990), La Pérdida de la propiedad indígena: el caso de Córdoba, 1573-1700, in: Anuario de estudios americanos 47, 171-198

Helguera Quijada, Juan (1995), Los despoblados y la política de colonización del reformismo ilustrado en la cuenca del Duero, in: Despoblación y colonización del Valle del Duero, siglos VIII-XX, IV Congreso de Estudios Medievales, Ávila, 375-411

Herzog, Tamar (2002), The Meaning of Territory: Colonial Standards and Modern Questions in Ecuador, in: Roniger, Luis, Carlos H. Waisman (eds.), Globality and Multiple Modernities: Comparative North American and Latin American Perspectives, Brighton, 162-182 
Herzog, Tamar (2007), Terres et déserts, société et sauvagerie. De la communauté en Amérique et en Castille à l'époque moderne, in: Annales HSS 62,3, 507-538

Herzog, Tamar (2013), Colonial law and 'Native Customs': Indigenous Land Rights in Colonial Spanish Amerika, in: The Americas 63,3 303-321.

Herzog, Tamar (2014), Frontiers of Possession: Spain and Portugal in Europe and the Americas, Cambridge MA.

Jovellanos, Gaspar Melchor de (1795), Informe de la Sociedad Económica de esta corte al Real y Supremo Consejo de Castilla en el expediente de la ley agraria, Madrid

Larkin, Pascal (1969), Property in the Eighteenth Century with Special Reference to England and Locke, New York

Lázaro Ávila, Carlos (1999), Conquista, control y convicción: El papel de los parlamentos indígenas en México, el Chaco y Norteamérica, in: Revista de Indias 59/217, 645-673

Levaggi, Abelardo (2000), Paz en la frontera. Historia de las relaciones diplomáticas con las comunidades indígenas en la Argentina (siglos XVI-XIX), Buenos Aires

Levaggi, Abelardo (2002), Diplomacia hispano-indígena en las fronteras de América. Historia de los tratados entre la monarquía española y las comunidades aborígenes, Madrid

Málaga Medina, Alejandro (1974), Las reducciones en el Perú (1532-1600), in: Historia y Cultura 8, 141-172

Maravall, José Antonio (1972), Estado moderno y mentalidad social (siglos XV a XVII), 2 vols., Madrid

Mariluz UrquiJo, José María (1976), El concepto de tierra nueva en la fundamentación de la peculiaridad indiana, in: IV Congreso Internacional de Historia del Derecho Indiano, México

Mariluz Urquijo, José María (1978), El régimen de la tierra en el derecho indiano, Buenos Aires

Neeson, J. M. (1993), Commoners: Common Right, Enclosure and Social Change. England, 1700-1829, Cambridge

Néspolo, Eugenia A. (2004), Los tratados escritos con las sociedades indígenas en los bordes del río Salado durante el siglo XVIII. Un análisis desde el derecho de gentes, in: Memoria Americana. Cuadernos de etnohistoria 12, 237-276

Niehaus, Thomas Kenneth (1976), Population problems and land use in the writing of the Spanish Arbitristas: Social and Economic Thinkers, 1600-1650, Phd. University of Texas at Austin

Oliveras Smitier, Jordi (1998), Nuevas poblaciones en la España de la ilustración, Barcelona

Ots Capdequi, José María (1959), España en América. El régimen de tierras en la época colonial, México

Pagden, Anthony (1986), Dispossessing the Barbarian: The Language of Spanish Thomism and the Debate over the Property Rights of American Indians, in: 
Pagden, Anthony (ed.), The Languages of Political Theory in Early Modern Europe, Cambridge, 79-98

Pagden, Anthony (1998), Dispossessing the Barbarian: The Language of Spanish Thomism and the Debate over the Property Rights of the American Indians, in: Armitage, David (ed.), Theories of Empire, 1450-1800, Aldershot, $159-178$

Palacio Atard, Vicente (1989), Las “nuevas poblaciones” andaluzas de Carlos III: Los españoles de la ilustración, Córdoba

Rau, Virginia, Maria Fernanda Gomes da Silva (1955), Os manuscritos do arquivo da Casa de Cadaval respeitantes ao Brasil, Coimbra

Real Academia Española (1732), Diccionario de la lengua castellana, Madrid

Rodríguez, M. Martín (1984), Pensamiento económico español sobre la población, Madrid

Rodríguez Castello, Hernán (ed.) (1997), Diario del padre Fritz, Quito

Rodríguez Puerto, Manuel J. (1996-1997), Derecho natural, propiedad y utilidad en el humanismo jurídico, in: Ius Fugit 5-6, 491-525

Slater, Gilbert (1907), The English Peasantry and the Enclosure of Common Fields, London

Solano, Francisco de (1976), Política de concentración de la población indígena: objetivos, procesos, problemas, resultados, in: Revista de Indias 35/145-6, 7-29

Solórzano Pereira, Juan de (1972), Política Indiana (1648), Madrid

Tawney, R. H. (1965), The Agrarian Problem in the Sixteenth Century, New York

Tomlins, Christopher (2010), Freedom Bound. Law, Labor and Civic Identity in Colonizing English America, 1580-1865, New York

Torales Pacheco, Christina (1990), A note on the composiciones de tierra in the Jurisdiction of Cholula, Puebla (1591-1757), in: Ouweneel, Arij, Simon Miller (eds.), The Indian community of colonial Mexico: fifteen essays on land tenure, corporate organizations, ideology, and village politics, Amsterdam, 87-102

Tully, James (1980), A discourse on Property. John Locke and his adversaries, Cambridge

Vassberg, David E. (1974), The Tierras Baldías: Community Property and Public Lands in 16th Century Castile, in: Agricultural History 48,3, 383-401

Vattel, Emer de (1916), The Law of Nations or the Principles of Natural Law (1758), trans. Charles G. Fenwick, Washington D.C.

Weaver, John C. (2004), Concepts of Economic Improvement and the Social Construction of Property Rights: Highlights from the English-Speaking World, in: Mclaren, John (ed.), Despotic Dominion: Property Rights in British Settler Societies, Vancouver, 79-102 



\title{
The Westernization of Police Regulation: Spanish and British Colonial Laws Compared
}

\begin{abstract}
“[...] porque todo o lo más, es nuevo [en las Indias] o digno de innovarse cada día, sin que ningún derecho, fuera del natural, pueda tener firmeza y consistencia, ni las costumbres y ejemplos que hayamos introducidos sean dignos de continuarse, ni las leyes de Roma o España, se adapten a lo que pide la variedad de sus naturales, además de otras mudanzas y variedades, que cada día ocasionan los inopinados sucesos y repentinos accidentes que sobrevienen." ${ }^{1}$
\end{abstract}

\section{Period Introduction: Legal Globalization in the Early Modern}

European law was the primary vehicle and export product of early modern globalization. European law spread with the Spaniards to Central and South America, and the Philippines; with the Portuguese to Brazil, Angola, Mozambique, Goa, and Macao; with the Dutch to Ceylon and Indonesia; with the French to Quebec and Louisiana; with the British to North America, Australia, and countless other places around the world; and even with the Danes to the islands of St. Thomas, St. John, and St. Croix.

Expansion was nothing new to European law at the outset of the modern age. European law had already expanded continuously pari passu with the expansion of the Roman Empire, and again after Roman law was revived in late eleventh century Bologna. The medieval expansion had meant that the learned bodies of law, Roman and canon, traveled from the southern parts of Europe to the north, from the western parts to the east, and from the cities to the countryside. Roman law traveled with the learned jurist, canon law with the Catholic Church and its churchmen. ${ }^{2}$

1 Solórzano y Pereyra (1648) IV.XVI.3, 260. I have modernized the spelling in the quote.

2 On the expansion of the law within medieval Europe, see Whitman (2009). 
To portray European law as a vehicle of globalization may seem Eurocentered. It is of course true that European law has not been the only body of law expanding in the pre-modern world. Islamic law went through a period of rapid expansion from the seventh century onwards. The solutions that the Islamic legal experts had developed, building on the heritage of the Semitic cultures of the Near East, were quickly absorbed not only in the cradle of the religion for commercial needs, but also in large areas of North Africa and Central Asia, to where Islam spread. ${ }^{3}$ Chinese law, especially the Confucian concept of $l i$, has traditionally exercised influence in large areas of the Far East. ${ }^{4}$ The same questions that I will ask about European law in this article could certainly be asked of Islamic and Chinese laws as well. However, it remains fairly clear that of all of these expanding laws of the medieval and early modern periods European law had most success in extending its sphere of influence around the globe, at least measured by sheer geography.

The term globalization, irritating slogan as it has become for many, can be called into question. No globalization has so far been complete in geographical terms - not even the present-day iteration based mainly on the law of the United States of America. Large tracts of the globe have always been left untouched, and even the picture of large tracts being completely dominated by extending bodies of law may prove misleading on closer inspection - and indeed almost always does. The learned ius commune applied in the emerging high courts of Europe in the early modern period was not the same as the law applied in remote local courts dominated by unlearned laymen. ${ }^{5}$ The difference is naturally even clearer if one compares the audiencias of Spanish America to the jungles of Amazonia.

Despite the unquestionable deficiencies in the terminology, globalization is still a useful term. It expresses huge waves of legal transfers, as opposed to mere isolated legal institutions, not linked to any wholesale cultural transfer, floating around the globe. The dimensions of legal transfer are certainly completely different if we take the Swedish-Danish institution of the ombudsman as an example of an isolated legal transfer, comparing it with whole

3 On the early expansion of Islam and its connection to the preceding cultures of the Near East, see HallaQ (2005) 8-28.

4 Chongko Choi even speaks of East Asian ius commune; see CHOI (2009).

5 Sweden is the particular case I have in mind. 
bodies of law being taken from one continent to another. We need to have a name for the larger phenomenon, and legal globalization is such a name.

Legal globalization, however, is not more than a huge legal transfer, and is subject to similar theoretical ponderings as the more limited legal transfers. It is a truism that all transfers change when adapted to new circumstances, and the new outcome looks different than the old one. The "receiving" culture and its new circumstances unavoidably influences the shape that the transfer takes. Comparative law scholars and comparative legal historians have written extensively on the material aspects of legal transplants: what rules are carried over and borrowed by other jurisdictions and how legal rules change in this process. However, comparative legal historians have written surprisingly little on the conditions which cause transplants to change and, accordingly, how they change. The methods of legal change themselves can sometimes be understood as legal transfer, however. The main contention of this article is that both the Spanish and the British colonizers of America made ample use of one such technique, early modern police regulations. The spread of police regulation to the New World led to globalization or at least thorough Westernization of this legal instrument.

Police regulations were, not however, merely a technique. Although they covered a wide array of regulations, they did not cover everything. Police regulations were about administration, commerce, security, health, and censorship, but they were much less about contract law, rules of evidence, or punishment.

I will start with some theoretical considerations regarding the concepts of European and Spanish colonial law (Section II). Section III, the main part of the article, will discuss the main themes in regard to which Spanish colonial law developed different solutions in comparison with its peninsular Spanish legal order(s). In Section IV, I will then attempt to explain these differences, comparing Spanish colonial law with that of the British North American colonies. Section V sums up the essential points of the article. 


\section{Globalization of Law}

William Twining defines globalization as "those processes which tend to create and consolidate a world economy, a single ecological system, and a complex network of communications that covers the whole globe, even if does penetrate every corner of it." ${ }^{6}$ The diffusion of Western law with early modern colonization not only fits the concept of globalization well, but also can in fact be taken as one of its primary examples. The concept of Western law still requires some discussion. What later became Western law - a term that Harold Berman made universally known - was the same as European law or ius commune, the learned law consisting of Roman and canon law at the beginning of the early modern period. European law, by the time the overseas conquests began, was already falling into regional subcategories because of the contact that ius commune made with particular local laws. ${ }^{7}$ The idea of Castilian regents was to incorporate the desired Roman legal texts into written statutes (most notably the Siete Partidas of Alfonso X the Wise) and prevent the use of Roman law otherwise. How successful this was is disputed. ${ }^{\mathbf{8}}$ In any case, the derecho común of Castile was clearly one of the

6 Twining (2000) 4. Twining's concept of globalization is, however, not historically very sensitive. Duncan Kennedy has, by contrast, approached the subject of globalization historically by distinguishing three periods of globalization in the West: the period of classical legal thought (ca. 1850-1914), the period of socially oriented legal thought (1900-1968), and the most recent period of "policy analysis, neoformalism, and adjudication" (1945-). See KenNedy (2006).

7 Many legal historians, most recently Patrick Glenn, in fact deny the existence of one ius commune, claiming that the Latin-based ius commune consisting of mainly Roman law never existed, but that it always appeared as regional variants only - gemeines Recht and Derecho común, for instance. See GlenN (2005) 42-43. Other skeptical views against the existence of a truly unified ius commune have been offered by OsLer (1997); Halpérin (2000) 724; and Heirbaut (2003) 304-305. These views are very different from the traditional ones represented by Francesco Calasso, Helmut Coing and most recently Manlio Bellomo. As a Nordic legal historian, the author of the present article cannot help but agree with the critical voices. However, the localized variants of ius commune had much to do with each other. The overarching learned law was practically the same everywhere, but since the local laws were different (written or not), the overall combination of the two (or more) layers of law turned out differently.

8 Again, opinions diverge as to whether the Siete Partidas amounted to a "Spanish common law," or whether the law book of Alfonso X was the highest layer of ius proprium, above which the pan-European ius commune still existed. See Barrientos Grandón (2000) 203; Petit (1982); Jacobson (2002). 
European variants of ius commune, sharing the essential features of both civil and procedural law with other variants of the European ius commune. This Spanish variant of European law served as the basis and bridge for what came to constitute the law for Spanish America from 1492 onwards.

We still have one more terminological hurdle to cross, the term "Spanish colonial law." Derecho indiano is the term most frequently used in Spanish to denote the legal system in force in the Spanish colonies during the early modern period. Like all geographical ways of limiting law, which is essentially a shifting phenomenon, so derecho indiano is also not a natural entity, but was created at a particular time and place. In this case, the term was put into historiographical use in the early twentieth century as part of the Hispanist ideology of that period. ${ }^{9}$ Like all geographical definitions of law, derecho indiano is helpful in distinguishing and pointing out a particular area of study from other such areas. However, by highlighting its particularity, derecho indiano also tends to conceal connections that the law in Spanish America had with Spanish and other European law. In this way, it does not differ from "European" or "Nordic" law. Like any national legal history, the research tradition of derecho indiano has tended to highlight its particularity instead of denoting its similarities (or differences) with other colonial systems or European law. In other words, comparative studies on Spanish colonial law have been completely lacking until recent years. ${ }^{\mathbf{1 0}}$ This is particularly strange considering that general historians have been engaged in comparative "Atlantic studies" since the 1970s. ${ }^{11}$ The lack of comparative studies tends to create an illusion of uniqueness of national (or quasi-national, such as derecho indiano) legal systems. Comparative studies tend to diminish such illusions.

This article challenges the uniqueness of Spanish colonial law in two respects. First, I wish to claim that Spanish colonial law was just one variant of European and Spanish law. Second, Spanish colonial law was only one version of colonial legal orders. Therefore, it can and should be approached

9 See PinlajamäKi (2010).

10 In this respect, Spanish colonial law is not different from the mainstream legal history on any of the discipline's subfields. Ross's article (2008a) is a notable exception, and I have myself authored a few articles in which derecho indiano is compared to European law from various aspects. See Pinlajamäki (1997); Pihlajamäki (2002) and Pihlajamäki (2004).

11 See Davies (1973); Elliott (1970); and Daunton/ Halperin (1999). 
in the global context of the expansion of European law to other continents. This does not mean that derecho indiano should not be used as an object of study - this article is doing just that, of course. Instead, scholars should be aware of the position of Spanish colonial law within a global context. It is necessary to understand that the concept of derecho indiano is essentially modern, created by legal historians trained in the period of national positive law. In this respect, it is no different from concepts like European, Nordic, or Far Eastern law. To portray Spanish colonial law as a separate or quasi-separate system of law would not have occurred to early modern Castilian or criollo legal professionals operating under the auspices of the Castilian Crown. I will now turn to the modern definitions of Spanish colonial law.

\section{What was Spanish colonial law?}

The Spanish Crown was quick to organize the administration of its overseas territories in America. Formally speaking, the Indies were incorporated into the Castilian Crown, although the Castilian kings were also the kings of Aragon. Because the American territories were incorporated as a conquered territory, it was up to the Castilian Crown to organize their administration without the institutional barriers that limited the authoritarian exercise of kingship in Castile. For instance, no Cortes, or representative assembly, was ever introduced on the American side of the Atlantic. ${ }^{\mathbf{1 2}}$

The legal order that regulated life in the colonies was basically Castilian law. This was based on the Siete Partidas, a thirteenth century compilation heavily influenced by Roman and canon law later supplemented by royal regulation and court practice. The legal scholarship on ius commune inevitably influenced Castilian law as well. Vigorous development by way of royal regulation was precisely what the early modern monarchs engaged in to gain increasing control of their lands. This royal legislation was police regulation.

According to a formal definition, Spanish colonial law was a "compound of legal rules applicable in the Indies, that is, in the American, Asian and Oceanic territories dominated by Spain." Spanish colonial law can therefore be divided into a. norms specifically created for the Indies (derecho indiano

12 Elliott (2007) 120-122. Elliott observes, however, that the institutional barriers limiting the royal authority had not become as important during the Middle Ages in Castile as they had in Aragon. 
propiamente tal o municipal); b. Castilian law (derecho castellano), which was used if "proper derecho indiano" did contain the normative solution needed; and c. Indian law (derecho indigena), or the law of the aboriginals. ${ }^{13}$ In addition to secular norms, we can also speak of the canon law of the Spanish colonies (derecho indiano canonico) as the canon law in force in Spanish America. ${ }^{\mathbf{1 4}}$ These definitions reveal that "proper" Spanish colonial law stood in relation to Castilian law, used as a subsidiary body of law whenever derecho indiano could not provide an answer. The same applies to the canon law of Spanish America and canon law in general.

When did derecho indiano propiamente tal, Spanish colonial law in the narrow sense of the term, not provide answers for legal problems? And when it did, what was Spanish colonial law "properly speaking"? Technical definitions do not take a stand on what kinds of rules "Spanish colonial law properly speaking" consisted of. In principle, it could contain all kinds of rules, especially if customary law is taken into consideration, but in practice it did not. If we want to set Spanish colonial law into a comparative context, we cannot avoid looking beyond technical definitions and attempting to understand the norms the Castilian regents thought appropriate to bestow on their possessions on other continents. ${ }^{15}$

Some modern authors have given material descriptions of Spanish colonial law. Ricardo Zorraquín Becú, one of the grand old men of the field defines derecho indiano as "a system of law, doctrines, and customs, created or accepted by the Castilian kings, in order to organize the spiritual or secular government of the Hispanic New World, regulate the condition of its inhabitants, direct navigation and commerce, and, above all, ensure the incorporation of the Indians into the Catholic faith." ${ }^{\mathbf{1 6}}$ Anyone acquainting themselves with the literature on Spanish colonial law cannot help noticing the heavy accent on these and other issues, and the lack of literature on others. Collections of papers issued regularly as a result of the conferences organized by the Institute of the History of Spanish Colonial Law (Instituto de Historia

13 “[E]l conjunto de reglas jurídicas aplicables en Indias, o sea, los territorios de América, Asia y Oceanía dominados por España." Dougnac Rodríguez (1994) 11.

14 See Duve (2008).

15 This is not to exclude local norm-giving, which occurred in all parts of Spanish America and at various levels of its administration.

16 Zorraquín Becú 22 (1994) 407. 
del Derecho Indiano) are a good way of obtaining an overview of what indianistas have produced - and what they have not been so interested in. ${ }^{\mathbf{1 7}}$

The Conference papers show a heavy emphasis on questions such as constitutional and administrative law, ecclesiastical law, mining law and water law. Much has also been written on the administrative institutions (such as cabildos and audiencias) and institutions of feudal law (such as encomienda). Considerably less has been written on the private law, criminal law, and procedural Law of the Indies. The scholarship on the history of private law in the Indies has tended to stress Spanish colonial law as part of the European ius commune. Much the same can be said about the literature on criminal and procedural law. ${ }^{18}$

The reason for the scarcity of scholarship in some fields and the concentration of scholarship in others is obvious: derecho indiano "properly speaking" was mostly the regulation of fields that needed special treatment in the Indies. Zorraquín Becú's definition of derecho indiano above hints at this trend, which I have treated in more detail elsewhere; namely, that much of derecho indiano propiamente dicho is in fact functionally the same type of legislation which has been called "police law" (Polizeirecht) or laws pertaining to "good government" (buen gobierno) in recent international legal historiography. Police law in the early modern sense of the word refers to the legislative activity of an early modern state, which organizes its administration with statutes, decrees, ordinances, and other pieces of legislation.

The ideology legitimating this often massive amount of legislation pouring from the chanceries of early modern kingdoms, towns, and other legislating entities was that of good government, Staatsräson or raison d'État. Areas as different as religion, security and public order, agriculture, industry and commerce, traffic, construction, culture and sciences, as well as the control of the poor and the marginalized, needed detailed legislation. ${ }^{19}$ In these various ways, early modern police ordinances attempted to create and maintain public order, discipline and stability, but at the same time promote

17 The Conferences have been organized at intervals of 2-4 years since 1966 in either Hispanic America or peninsular Spain.

18 See, for instance, the conference proceedings mentioned above, note 10 (Рінцаjamäкi).

19 In recent decades, the literature on police has grown immensely, and no comprehensive list is worth attempting here. See, for instance, Stolleis (1993), Härter/Stolleis (1996) and the subsequent parts of the series. 
the well-being of society. ${ }^{\mathbf{2 0}}$ Church ordinances in the reformed parts of Europe came very close to police ordinances. In some parts of Europe, such as Sweden, separate church police regulations (kyrkopoliti) were issued, but not church ordinances. ${ }^{21}$

The emergence of police regulation is thus closely linked to the rise of the modern state and modern absolutism. Spain was no exception to this general European tendency. Johannes-Michael Scholz has noted that the Spanish legislator's interest in police matters grew considerably between the Nueva Recopilación of 1640 and the Novisima Recopilación of $1805 .{ }^{22}$ Police law was the most modern regulatory tool that the early modern prince aiming at absolute power had at his disposal, although one has to bear in mind that the effectiveness of police regulation often left much to be desired. Although police law was a tool of the monarch, its legitimating ideology also imposed limits on the use of police, because the regulations could only be used to further the common good, the bonum commune.

From the very beginning of the conquest, the Spanish Crown issued a large number of statutes to regulate life in the Indies. The jurist Antonio León Pinelo is said to have extracted the thousands of royal cédulas that made up the Recopilación de las leyes de Indias, a compilation of statutes printed in 1680 but already finished in 1635 , from approximately 400,000 laws. ${ }^{23}$ The laws tended to govern every detail of routine administration and were often extremely casuistic, as police regulation tended to be. Clarence Haring mentions, as examples of the areas governed, "the fixing of prices, the ferry charge on the river at Santo Domingo, the right to own fishing boats, permission to import from Spain cattle and foodstuffs necessary for the subsistence of the new overseas communities, the right to engage in local trade with nearby settlements, or to build vessels for such a trade; the exact manner in which a town must be laid out, the width of the streets and their direction in relation to the sun, the size and subdivision of the city blocks, the location of the church and the town hall." ${ }^{24}$ Religious matters could with good reason be

20 HÄrTER (1993) 62-63.

21 On the different concepts of police in relation to ecclesiastical administration, especially in Germany, see Stolleis (1992) 250.

22 See Scholz (1996) 230-231.

23 Haring (1947) 113. Haring says that the final Recopilación contains 6400 cédulas, whereas more recent scholarship mentions the figure 7308; see Dougnac (1994) 11.

24 Haring (1947) 120-121. 
added to the list, making it look like a rather typical catalog of police regulation in any region of the early modern Western world.

The amount of legislation was indeed such that it soon started to call for some sort of general presentation. Both compilations and literature started to appear to meet this need. Of the scholars in the field, the most famous was Juan Solórzano Pereira, who was a judge of the Audiencia of Lima. The leading derecho indiano author of the colonial period, Solórzano's major work, Politica Indiana (1648), deals with "the law and the government particular to the Indies" (Derecho y Gobierno particular de las Indias). ${ }^{25}$

The work is divided into six "books," which deal with the discovery of America (I), the social position of the aborigines (book II), the creoles as landowners (book III), ecclesiastical government (book IV), as well as administrative (book V) and economic organization (book VI) of the Indies. The general plan of the book reveals that Solórzano's politica was essentially similar to European police regulations. In the second book, chapters I-XXIV are about the "personal services" of the Indians, such as the construction of buildings (II.VIII.1.-14.), agriculture (II.IX.1.-40.), the postal service (II: XIV.1.-32.), mining (II.XV.1.-56.), as well as tributes (II.XIX.1.-56.) and tithes (II.XXIII.1.-43.). These are all areas of regulation central to the European ius politiae.

Because we are dealing with a particular kind of police regulation, Solórzano Pereira's magnum opus, however, is almost completely devoid of major areas of law such as private, criminal, and procedural law. The law in these areas by and large followed Castilian law, which, in turn, was just one version of the European ius commune.

The huge amount of the laws was also compiled, first as private initiatives, then as more official ones as well. The cedulario (register of royal laws and decrees) of Vasco de Puga, judge of the New Mexico audiencia, was printed as early as the 1560 s. The registers proved helpful in compiling the work, and later compilers also used them as material. Antonio León Pinelo, as mentioned above, bore the main burden of compiling the major general collection of laws of the laws of the Indies. The work took place under the supervision of first Rodrigo de Aguiar y Acuña and then Juan Solórzano Pereira.

25 Solórzano y Pereyra (1648) I.I.1, 22. The work first appeared in Latin as De indianum iure in 1629. 
Once completed, copies of the compilation were sent to viceroys, audiencias, cabildos, and other major figures of the Spanish colonial administration. ${ }^{\mathbf{2 6}}$

The Recopilación is divided into nine books, which include - roughly speaking - ecclesiastical government (I), matters concerning the Council of the Indies and audiencias (II), political and military administration, viceroys, and captains-general (III), the legal foundation of colonization (IV), provincial government $(\mathrm{V})$, Indians $(\mathrm{VI})$, criminal law (VII), the royal exchequer (VIII), and commerce and navigation (IX). ${ }^{27}$ The titles of the books are quite telling of the contents of the compilation and thus of Spanish colonial law itself, since the material included in Pinelo's compilation concentrates heavily on the administration of various kinds and commerce.

Book VII, the provisions of which share elements of penal law, is by far the shortest and far from intended as a comprehensive criminal code. Its eight headings include regulations on judges (1), games and players (2), marriage problems resulting from husbands being away from their wives in America (3), vagabonds and gypsies (4), the black people and those of mixed race (5), prisons (6), prison inspections (7), and crimes and punishments (8). Most of the titles thus again deal with matters of typical police regulation. Criminal law as such is not the point here, not even in heading 8 on crimes and punishment, the 29 laws of which are really a haphazard collection of regulations concerning matters of particular concern for the Crown in the colonies. For instance, law 11 of heading 8 requires that those sentenced to the gallie should be sent to Cartagena or Tierrafirme to serve their sentences. According to law 15, the judges ought not to moderate the legal punishment - which was probably also customary in America as elsewhere in the Western world. Furthermore, law 17 established that judges should refrain from accepting settlements except in "very special cases, at the request and wish of the parties, and if the case was such that it [did] not require satisfaction to the public cause."

The examples are numerous, but I think the point is clear: Book VII is no penal code in the sense of Constitutio Criminalis Carolina (1532) or Ordonnance de Villers-Cotterêts (1539), but rather a collection of rules not capable of functioning without the general background of Spanish penal and proce-

26 Haring (1947) 113.

27 The Recopilación is now conveniently available on the Internet, http://www.congreso. gob.pe/ntley/LeyIndiaP.htm. 
dural law. This is even more obvious if we think about private law, on which the Recopilacion is practically silent.

I will take one more example of the Spanish colonial legislation from a particular part of the Spanish colonies, for which the catalogues of statutes have recently been published, Río de la Plata (1534-1717), Charcas (15631717), and Tucumán and Paraguay (1573-1716). The great majority of the statutes catalogued in these registries can, hardly surprisingly considering what has been said above, be classified as police law. Some of the statutes deal with administration, religion and the protection of aborigines. A vast majority, however, has to do with the economy and the military. ${ }^{28}$ Again, criminal, procedural, and private law remain only sporadically regulated.

The precise character of police regulation as "law" is not clear either. Police regulations were, for instance, left out of the Swedish Law of the Realm of 1734, a compilation of laws otherwise thought perfect and unchangeable. The natural law ideology underlying the compilations designed as eternal in fact demanded the exclusion of police regulations because of their mutable character.

Was derecho indiano really considered law, in the natural law understanding of the word? At least the name of the original Latin version of Politica Indiana, De indianum iure, suggests as much, although the title of the Spanish translation seems to convey that we are moving in the borderlands of law and more practical regulation. Another essential and specific characteristic of Spanish colonial law often mentioned in the literature is its changing character. The law adapts to circumstances, which change, according to Tau Anzoátegui, "quicker than ... is experienced in other, more consolidated societies." ${ }^{29}$ In his Casuismo y sistema (1992), Tau Anzoátegui shows how the notion of the mutability of the Indian world became common currency at the beginning of the sixteenth century, and remained so all through the Spanish conquest. ${ }^{30}$ Gaspar de Villarroel, one of the leading American legal scholars of the seventeenth century wrote that "it is impossible that in this new world the government were firm and stable, and that the laws were

28 See Libros registros-cedularios del Río de la Plata I-III (1534-1717) (1984-1991); Libros registros-cedularios de Charcas (1563-1717) (1992-1994); Libros registros-cedularios del Tucumán y Paraguay (1573-1716) (2000); and PinlajamäKi (2002).

29 Tau Anzoátegui (1992) 108.

30 Tau Anzoátegui (1992) 108-114. 
lasting: because there is such a large number of particularities, in the cure of which the laws assist, the human animal varies so much that today he is disturbed by the same medicine that healed him yesterday."31

The changing nature of Spanish colonial law also goes hand in hand with the changing nature of police law in general. The need for constant and rapid change was even greater in the distant American lands, which were not only remote but also internally disparate. The modern legislative technique of ius politiae was extremely suitable for such circumstances. The institution of "obedience without compliance," the inheritance of medieval Castilian law, came to serve much the same goal of constantly accommodating legislation to local needs. ${ }^{32}$

The whole legislative ideology changed in the modern era. In the middle ages, legislation, at least in theory, had not created new law but only followed tradition. In the absolutist state, all this necessarily ended: from now on, the sovereign's command was law. Law could be changed anytime and basically in any way the sovereign wished, as long as he respected the limits of natural law and the law of God, and as long as his commands worked in favor of the common good. This type of legislation, as Stolleis has remarked, could easily react to the changing circumstances but was lacking "scientific coherence." In this sense, a police statute was in fact closer to the individual command of the sovereign than to a law intended to last. Because of this "lack of jurisprudential character" (Marginalitäten des juristischen Elementes) in Germany (and elsewhere), police statutes were not taught in law faculties of the universities until the nineteenth century, but rather shoved over to philosophical faculties. ${ }^{33}$

In short, corresponding to the latest trend in European statutory law, Spanish colonial law was police regulation. This can be said, I think, at least

31 "Es imposible que en este nuevo mundo sea firme y fijo el gobierno, y que las leyes humanas sean duraderas: porque sobre ser tan sin número los casos particulares, a cuyo remedio asisten las leyes, es el hombre animal tan vario, que hoy le turba la salud la medicina que le sanaba ayer." Villarroel, Gobierno, II, XVII, IV, 14. Cited at TaU AnZoátegui (1992) 111.

32 The principle of "obsérvase pero no cumpla" allowed the authorities of the Spanish colonies, as an individual statute did not seem suitable for the local circumstances, to leave the statute unapplied while at the same time not formally violating it. Elliotr (1970) 131-132.

33 Stolleis (1992) 244. 
as long as we do not stick to a formalistic definition of Spanish colonial law, which defines it as everything applied in the Spanish law. Derecho indiano was police law if we concentrate our observations on what was typical of derecho indiano propiamente dicho; in other words, the parts of Spanish colonial law which differed most from the compound of the laws of peninsular Spain and which were most typical of the Indies - typical in the sense that the police regulations formed the kernel of Spanish colonial law. In this respect, derecho indiano was no different from the law in most regions of Europe.

The comparative research question that now almost automatically arises is whether the same can be said of the other colonial legal orders of the early modern period. Alternatively, are we allowed to continue to speak of derecho indiano in terms of exceptionalism that until now has dominated the discussions, if not expressly then at least as a tacit presumption? I shall now move on to these problems.

\section{Comparative Aspects: British Colonial Law in North America}

I will now briefly discuss the case of British colonial law in North America. The precise question is: To what extent did statutory regulation in the British American colonies resemble derecho indiano, and in what respect were the two different from each other?

The point that I wish to make in this section is that one of the many ingredients that English law around 1600 shared with continental law was police regulation, and that this kind of regulation found its way into the British North American colonies as well. In developing police regulation, England was no different from the German territories, Sweden, or France. In all of these polities, legislative powers not only sometimes published codes but also issued great quantities of piecemeal legislation on all walks of life. In German legal language, this kind of legislation came to be conceptualized as "police" (policey); elsewhere, the conceptualization was either lacking, or was ill-defined. The phenomenon, according to present scholarly understanding, was the same everywhere. A brief look at the colonial legislation quite clearly reveals that the British colonies in North America were no exception. Why should they have been, eager as they were to utilize many other facets of English law as well? I will thus claim that it does not suffice, as far as colonial legislation is concerned, to pay attention to the colonial codes 
that have rightly merited much scholarly attention. It is also worthwhile to look into the abundant colonial police regulation.

The emphasis that scholars have recently placed on the complex nature of English law at the inception of the colonial period in America is pivotally important. As David Thomas Konig observes, the diversity of North American law can hardly be understood without understanding the context of early modern English law. Despite the common law's position at the courts of Westminster, English law was far from uniform. Sir Edward Coke, for instance, enumerated more than 100 courts in the realm, including ecclesiastical courts, manorial courts, and merchants' courts on his list. "The reach of the central common law courts, according to Konig, was "according to local forces and practices." ${ }^{34}$ It has been calculated that approximately fifteen different bodies of law governed the life of an average Englishman in 1600: no wonder William Blackstone lauded the fact that "the law hath appointed [such] a prodigious variety of courts in England.35

England's legal culture thus offered huge potential upon which to construct the legal orders of the colonies. William Offutt explains that the farfrom-uniform seventeenth century English law provided colonial legal literates ample material, or "legal capital," on which multiple legal solutions could be drafted. The legal literates made conscious choices between the various legal inheritances "to accommodate, prioritize, and integrate" them into a coherent system, Offutt argues, and ought not to be regarded as primitive versions of metropolitan law. ${ }^{36}$ It is crucial to understand that colonial law did not turn out the way it did by force of accident. However, as far as I have been able to determine, none of the contributors to the debate have discussed one important choice that the framers of colonial law made, which links it not only to English metropolitan law but also to Spanish colonial law. ${ }^{37}$ This is the nature of North American colonial law as police regulation.

34 Konig (2008) 151; see also Hulsebosch (2003); Offutt (2005) 161.

35 Blackstone (1765-1769), 3:24, 30.

36 Offutt (2005) 161. Offutt's main point is that by the 1680 s and 1690 s "the multiple sources that had originally nourished colonial legal imaginations were slowly dying out." Instead, "the common law $[. .$.$] became virtually the only form of legal capital still flowing$ across the Atlantic." Offutt (2005) 161-162.

37 Richard Ross, however, touches upon the subject in his comparative article on the aspect of religious discipline, drawing on Massachusetts, Genevan, and Scottish sources. See Ross (2008b) 975-1002. 
In recent decades, legal historical scholarship on police regulation has spread from Germany to other regions of early modern Europe. ${ }^{38}$ Scholars have confirmed that similar regulation existed practically everywhere. ${ }^{39}$ England is no exception, although little research has been done on English police regulation from the comparative point of view. This may be a result of the traditional exceptionalism and isolation of English legal history, although critical research has recently lowered the barrier between common law and civil law. ${ }^{40}$

As far as I know, Robert von Friedeburg's article on English police regulation (which he calls Ordnungsgesetzgebung) is the only study on the subject. Royal proclamations and parliamentary statutes were, as von Friedeburg shows, both instruments of police regulation. In the years 1485-1553, at least 437 proclamations were issued. Many of them were, however, intended to strengthen the authority of the statutes, and sometimes proclamations only gave further instructions in regard to parliamentary statutes. ${ }^{\mathbf{4 1}}$ Statute law, according to the dominant theory of the sixteenth century, was the leading source of law because it stemmed from Parliament. Under Thomas Cromwell, a period of statutory reform was instigated, and during Henry VIII's reign alone, 677 statutes were issued. ${ }^{42}$ Both the proclamations and the statutes of the late fifteenth to early seventeenth centuries covered very much the same matters as police regulation everywhere else in Europe: commerce, luxury, clothing, poor relief, vagabondage, health care, and religion, to mention but some of the most typical. ${ }^{43}$ Royal proclamations, according to the prevailing scholarly understanding, probably had little

38 One notable exception is RaEFF (1983), in which the author compares German and Russian police regulations in the early modern period. In the history of police regulation, Raeff was also an early starter and could therefore not take into consideration all the research in the field that has actually emerged only since the 1990 s.

39 See the articles in Stolleis/Härter/Schilling (1996).

40 See, for instance, Zimmermann, who has on many occasions emphasized the similarities of legal institutions on both sides of the English Channel; see, e. g., Zimmermann (1993); and Freda, who has stressed the fact that not only common law but also early modern continental legal orders were very much driven by court precedents; see FreDA (2009) 263-278.

41 Friedeburg (1996) 583-584.

42 Friedeburg (1996) 586.

43 See Hughes / Larkin (1964), (1969a) and (1969b). 
practical effect, or at least we know little of their effects. ${ }^{44}$ This, again, fits the general European pattern. The fact that the English police regulation can be observed from the point of view of domestic power politics of the estates and the Crown, does not, however, prevent one from seeing the English royal proclamations and parliamentary statutes as essentially part of the same wave of police regulation that was taking over most of Europe in the early modern period. There was, no doubt, English policey. ${ }^{45}$

Written law, the actual "codes" included, was even more important for the colonies than for England. The colonists could not wait for the inherited common law doctrines to develop so as to meet the specific needs of the Americans. As a text-book of American legal history says, "England [...] had no need to consider, in its law, the problem of hostile native tribes [...] Some variations were natural - they stemmed from climate or the lay of the land; others were structural, depending upon whether the colony was a Crown colony, a chartered colony, or a proprietorship [...] Initial differences in land or structure led to still further differentiation." ${ }^{46}$ William Nelson has observed that in Virginia, the "rulers sought to accomplish their main chore, which was to coerce labor out of the local inhabitants, through intimidation and brutality, while New England's leaders strove to create a religious utopia by recourse to the law of God, not the law of England." These norms took the form of statutory law, such as Dale's Code of Virginia (1611), in addition to which English customary law was also used. In the initial period of the colonization, however, English common law was not on the agenda. ${ }^{47}$ Common law with all its intricacies was simply too sophisticated a tool for directing the new colonies effectively and, what is more, it could not function without lawyers. Common law might have been, as Lawrence Friedman puts it, "somehow the norm; colonial differences, then, were examples of some sort of rude primitivity". ${ }^{\mathbf{4}}$

44 Eliot (1965); Friedeburg (1996) 583.

45 Von Friedeburg remarks that the English language did not follow the continental terminology in transforming the Aristotelian "polity" to "policey" during the seventeenth century (Friedeburg (1996) 579). This does not, of course, mean that the English were not aware of the continental development or that the English "police" were completely different from its continental counterpart.

46 Friedman (1985) 37.

47 Nelson (2008) 16.

48 Friedman (1985) 34. 
The common law gained importance over time as soon as lawyers started arriving. These "legal literates" often had legal education and continued enhancing their need of legal information by reading English treatises. ${ }^{49}$ The legal orders of the colonies were also controlled by the Privy Council in London, although, as Richard Ross has observed, the Council's decisions were too few to control legal life in the colonies effectively. The Privy Council only took relatively few cases from the colonies under consideration. In this respect, the difference from Spanish America is clear: it was much easier for private individuals and authorities to have their cases heard in the Council of the Indies than it was for the British colonists to reach the Privy Council. ${ }^{50}$

Even the common law turned out differently in America. In many cases, English legal doctrines needed to be simplified to suit the needs of the colonies. For instance, the writ system was not adopted as such. The less technical bill procedure was used instead, at least in Virginia. ${ }^{51}$ Many cases did not come to court at all because of the widespread use of arbitration and mediation, and in most of the colonies juries decided both questions of fact and law. ${ }^{52}$ Nor did the professional division of lawyers into solicitors and barristers develop.

The level of legal culture is still another factor, which unavoidably affected the closeness of colonial law to English law. At least around 1700, colonial legal culture was underdeveloped, as seen through the eyes of an English observer. The lawyers had received little or no training at an educational institution such as the Inns of Court, had not been formally admitted to a professional organization, and lacked the social status of their English counterparts. ${ }^{53}$

Although the colonists thus adopted the basic blueprint of English law, they did so only with many deviations from the original model. The deviations were typically simplifications, necessary because of the initial lack of lawyers and their later scarcity. The functioning of the English common law would have been unthinkable in its original form in the absence of lawyers able to master its technicalities.

49 See BiLder (1999) 83-102.

50 Ross (2008a) 118-121.

51 Nelson (2008) 37.

52 Nelson (1975) $\mathrm{x}$.

53 See Konig (2008) 157. 
Not all changes were due to the lack of lawyers, however. Some resulted from the fact that the circumstances in America were radically different from those in England, where the common law doctrines had emerged. England's sixteenth century experience of extending its justice system into the Welsh and Northern marchlands, Ireland served as a background for events in Virginia and, despite differing circumstances between North America and Virginia, there were also many similarities leading to similar outcomes. ${ }^{54}$

In Wales and the North, instead of a fully developed common law system, judicial power was entrusted to the local lords and their conciliar courts with a simple royal commission, which granted barons broad discretion in shaping justice. Hardly surprisingly, it came to look quite different from the common law. The conciliar justice involved no juries. Legal proceedings were speedy, as no common law protection shielded the accused in criminal cases and because the complicated forms of the civil procedure were not followed. As David Thomas Konig observes, the Crown was forced to tolerate these deviances from the common law as the price for maintaining at least minimal control over these areas. Later on, the same pattern emerged in Ireland, as the Tudors extended conciliar justice there, leaving the central courts at Westminster with little influence on the island. In Ireland, just as previously in Wales and the North, the interests of a centrally led but complicated common law needed to yield to a more straightforward and discretionary judicial power. Little external constraint or accountability was imposed upon any of these courts. ${ }^{55}$

However, unlike Wales and the northern marshlands, conciliar justice failed in Ireland, largely because of the weaker status of the local magnates. Conciliar justice ultimately made way for the common law, which, better equipped as it was to secure land tenures, served the interests of English colonizers and land owners more effectively. ${ }^{56}$

The first phase of colonization in North America followed similar patterns. The leaders assumed and were granted wide powers in organizing legal administration, and they largely ignored and bypassed English common law developments. By the 1630s, however, the initial phase of "marshland justice" was over. Eight common law courts replaced the monthly courts that

54 Konig (1991).

55 Konig (1991) 72.

56 Konig (1991) 78. 
had delivered justice hitherto, and sheriffs took the place of provosts-marshals. In 1632, the General Assembly ordered that justice be administered "as neere as may be, accordinge to the lawes of England." 57

At the beginning of colonization, since it was often unclear which law should be applied, so-called introduction statutes were issued in some colonies. ${ }^{58}$ A principle developed over the years, according to which the laws of the colonies should not be repugnant to the English laws although differences arising from the needs of the place and the people could arise. Mary Sarah Bilder calls this the "transatlantic constitution," According to Bilder, the "constitution" was unwritten, although it sometimes found its way into legal documents. The Rhode Island Charter of 1663 expresses these principles of repugnancy and divergence as follows: ${ }^{59}$

[T] he laws, ordinances, and constitutions [of Rhode Island], so made, be not contrary and repugnant onto, but as near as may be, agreeable to the laws of this our realm of England, considering the nature and the constitution of the place and people there. ${ }^{60}$

Until the eighteenth century, it remained unclear whether and to what extent the laws of England, the common law statutes, would apply in the colonies. The so-called introduction statutes solved the problem by determining the circumstances in which the English law would apply. Rhode Island's introduction statute of 1700 declared that English law would be executed if the colony's own laws would not cover the case. ${ }^{61}$ English law was, in other words, given subsidiary status in a true ius commune sense of the term.

Both the discretion left to the local magnates in charge of shaping conciliar justice in Wales, Northern England, and Ireland and the failure of conciliar justice in Ireland and North America reveal important things about how laws were transferred to colonies in the early modern period. The initial phase of legal development in the North American followed much the same pattern of simplified justice. The way legal orders took shape was not merely influenced by political realities, the practical need to allow concessions to those actually in charge of representing the political power of the Crown.

57 Konig (1991) 92.

58 BiLder (2008) 99.

59 BiLDER (2004) 1.

60 BiLder (2004) 2.

61 BiLder (2008) 98-99.

116 Heikki Pihlajamäki 
The local holders of judicial power also had to gain legitimacy among the populace. In other words, political alliances decisively determined how justice would and could be shaped.

The political power alignment was nevertheless only one determinant. Another was geography. Time and space both created challenges from the point of view of maintaining a genuinely English system of common law, even after the common law courts had been established in the 1630s. The geographical differences per se sometimes called for different legal arrangements. The time factor also played a role since crossing the ocean took time, as such the colonists were not always aware of the latest legal developments in England, at least not right away. ${ }^{62}$ In this respect, British North America was similar to Spain's South America. Another similarity was that the local circumstances, in both parts of America, soon came to be controlled by a similar legislative technique, police regulation.

If English police regulation has attracted little attention, the American equivalent has produced even less scholarship; in fact none. The English Crown produced relatively little special legislation for the American colonies, which is a major divergence from Spain's relations with its overseas colonies from a comparative point of view. Taking into consideration the fact that police regulation was far from unknown in England, the scarcity of British legislation in America cannot be explained by the existence of a common law tradition. The lack of royal laws can be understood much better when observed against the context of the relative laxness of colonial practices on the British side of the Atlantic.

In Spanish America, various authorities were constantly reporting on each other to the Crown. The activities of Spanish officials could be checked in various ways. The visita or visitation, an institution developed in medieval canon law and known in many parts of Europe, could be imposed upon an official as a result of an individual complaint to Consejo de Indias or if suspicions had otherwise arisen. At the end of his term of office, every official's activities were checked as a matter of course in the residencia

62 But, as Ross remarks, "the great distances that the Atlantic Ocean created between colonies and metropoles provides (by itself) a weak explanation of the forms of imperial governance in the Americas. The English and Spanish empires, which both spanned the Atlantic, established different systems of legal communication that grew out of the dissimilar political and social contexts." Ross (2008a) 118. 
procedures. ${ }^{63}$ The English Crown imposed no such routine scrutiny on the American authorities. ${ }^{64}$

The British issued important legislation regarding the whole Empire, especially on commerce, such as the important navigation acts, laying the basis for British mercantilism. ${ }^{65}$ Although the English otherwise allowed the local authorities much more freedom in deciding how to run the colonies, some royal proclamations dealing specifically with colonial issues were nevertheless issued. Examples include the proclamation on forbidding a lottery in Virginia and the one forbidding the importation of tobacco from elsewhere than Virginia or the Summer Island. ${ }^{\mathbf{6 6}}$ Royal proclamations, at least under James I were, however, few. Almost all of them dealt with transatlantic questions, typically commerce.

A more voluminous statutory regulation, intended to regulate the colonial affairs per se, was worked out on the spot in the colonies themselves. In line with the dual authority system of the British colonial world, by the late seventeenth century it had become clear that not only the Crown but also all colonial assemblies were entitled to draft, enact, and change their own laws, although they were then subject to review by the Crown. ${ }^{67}$

Virginia's statutes are a good example of the use of statute law in the English colonies in North America, because Virginia's legislation was one of those imitated by the other colonies. William Hening collected Virginia's statutes from 1619 to $1823 .{ }^{68}$ This is not the place to thoroughly survey Hening's Statutes at large. Henning's Statutes fill thirteen volumes, and the amount of statutory law did not show signs of diminishing towards the end of the colonial period.

Even a brief look into the index of the Statutes reveals that the Virginian statutes fall squarely into the general pattern of Western early modern police regulation. Early Virginians legislated on bastards (1657), church wardens (1623), drunkenness (1632), fences (1642), hunting (1642), powder (1642), coinage (1645), trespassing animals (1748), weights (1748), and beggars (1755) to mention only a few of the typical areas of statutory law. They do

63 Haring (1947) 148-157.

64 Elliott (1970) 126.

65 See Priest (2008) 406-407.

66 LARKIN/Hughes (1973) 500-502, 627-632.

67 BiLder (2004) 55.

68 Hening (1923). 
not essentially differ from the police regulation in continental Europe: piecemeal legislation disciplining and controlling every aspect of people's everyday lives.

Customary law soon started to develop in its own directions in both the Spanish and English colonies. Nevertheless, both were also very much governed with the help of statutory law. There are, however, two major differences between the ways in which police regulation was employed. The first major difference is that whereas the vast majority of statutory laws in the Spanish colonies originated in Madrid, an overwhelming majority of the statutes in the English North American colonies were produced in the colonies themselves. Both Spanish and English colonizers took advantage of the most modern legislative technique, the policey. In both cases, some of that legislation was produced on the spot, in the colonies themselves. The second major difference between the Spanish and English colonial legal orders is that that the law in the English North American colonies grew further apart from the laws of the mother country. It seems that this was not so much due to the greater geographical differences or other local needs (which exists to a similar extent in both North and South America) but simply because the Spaniards were able to keep their lawyer-civil servants on a tighter leash better than the English could theirs, as shown by scholars such as J. H. Elliott and Richard Ross.

Another factor contributing to greater uniformity of derecho indiano as against North American law was, undoubtedly, the Castilian legislator's greater propensity towards unification. Statutes emanating from the Consejo de Indias were recorded in the cedularios, registries kept by the local authorities, which enhanced their usability. The greater centralization of Spanish law is also reflected in the way its laws were codified. The Recopilacion of 1680 has no counterpart in North America, although North Americans did not resist the idea of statutory law or codification as such. The English colonies began to publish authoritative collections of their laws early on, in addition to which private collections also appeared. ${ }^{69}$ Although the differences within the vast area of the Spanish Empire were many, the American colonies had been allowed to drift even further apart, legally speaking, at an early stage.

69 As examples can be mentioned For the colony in Virginea Britannia (1612), Coтton (1641), and The Book of the General Laws and Libertyes (1648) of Massachusetts. 


\section{Conclusion: the Westernization of Police Regulation in the Early Modern Period}

I have attempted above to demonstrate how the early modern colonialism took advantage of the most modern form of contemporary legal techniques, police regulation, not only in practically all corners of Europe, but also everywhere in the Western world. Although it may seem self-evident and hardly revolutionary to us now, police regulation is, just like any other major legal phenomenon, a historical product developed in time and space. The amount of literature produced on codification, court decisions, and - as far as Europe is concerned - police regulation, shows that it is hardly insignificant which form law takes.

The substance of American police regulation has not been given much consideration in this short piece. Such an undertaking would certainly require more time and space than I presently have at my disposal. Police regulation was a good legal technique to import to the British colonies because it typically did not require professional lawyers as draftsmen or users. The English common law did, the European ius commune did, and codifications have always required expertise. Police regulation was also quick and flexible - to what extent it was also effective may be questionable.

Just like the English, so the Spaniards also used the whole array of legal techniques available in peninsular Spain to govern their overseas territories. The traditional areas of civil, criminal, and procedural law could be transported over to the Indies relatively easily with the corps of legal professionals following in the footsteps of the actual conquistadores. The traditional legal techniques - scholarship, court decisions, and codes - were, however, not quick and flexible enough to master the multitude of new circumstances and peoples to which the law needed to react. Instead, the heart of Spanish colonial law, derecho indiano, also came to be based on police regulation, of which Spaniards had already gathered plenty of experience on the peninsula.

Police regulation as a legislative technique was a legal transfer, and legal transfers adapt to new social and political circumstances, often changing while they are moved from one place to another. In at least one important respect, police regulation in Spanish America was crucially different from police law in British America. In the latter colonies, the bulk of the regulation was drafted and issued in the colonies themselves, reflecting the rel- 
ative independence of the British colonies from London. In the Spanish colonies, however, the majority of the regulation continued to flow from the Council of the Indies right up to the end of colonial period, thus reflecting the centralized nature of the Spanish Empire.

Are we thus entitled to speak of a globalization of police regulation? This may have to await further studies on Dutch, French, and Portuguese colonial laws. At the moment, in any case, it seems fair to assume that in the early modern period, police regulation became at least thoroughly westernized.

\section{Bibliography}

Barrientos Grandón, Javier (2000), Historia del derecho indiano del desbubrimiento colombino a la codificación, vol. I: Ius Commune - Ius Proprium en las Indias occidentales, Roma: Il Cigno Galiei

Bilder, Mary Sarah (1999), The Lost Lawyers: Early American Legal Literates and Transatlantic Legal Culture, in: The Yale Journal of Law and Humanities 11, $47-116$

Bilder, Mary Sarah (2004), The Transatlantic Constitution: Colonial Legal Culture and the Empire, Cambridge, Mass.: Harvard University Press

Bilder, Mary Sarah (2008), English Settlement and Local Governance, in: Grossberg, Michael, Christopher Tomlins (eds.), The Cambridge History of Law in America: Volume I, Early America (1580-1815), 63-103

Blackstone, William (1765-1769), Commentaries on the Laws of England, reprint, Chicago: Chicago University Press 1979

Сног, Снолgко (2009), East Asian Jurisprudence, Seoul: Seoul National University Press

Cotton, John (1641), Abstract or the Lawes of new England, London

Daunton, Martin, Richard Halperin (1999), Empire and Others: British Encounters with Indigenous Peoples, 1600-1850, Philadelphia: University of Pennsylvania Press

Davies, Ralph (1973), The Rise of the Atlantic Economies, Ithaca: Cornell University Press

Dougnac Rodríguez, Antonio (1994), Manual de historia del derecho indiano, México D. F.: Universidad Nacional Autónoma de México

Duve, Thomas (2008), Sonderrecht in der Frühen Neuzeit: Studien zum "ius singulare" und den "privilegia miserabilium personarum", "senum" und "indorum" in Alter und Neuer Welt, Frankfurt am Main: Vittorio Klostermann

Eцiot, G. R. (1965), Government by Edict, in: Journal of History 8,2, 266-271

Elliott, John H. (1970), The Old World and the New, 1492-1650, Cambridge: Cambridge University Press 
Elliott, J. H. (2007), Empires of the Atlantic World: Britain and Spain in America 1492-1830, New Haven: Yale University Press

For the colony in Virginea Britannia: Lavves diuine, morall and martiall, 6c. (1612)

Freda, Dolores (2009), 'Law Reporting' in Europe in the Early-Modern Period: Two Experiences in Comparison, in: The Journal of Legal History 30,3, 263-278

Friedeburg, Robert von (1996), Ordnungsgesetzgebung Englands in der Frühen Neuzeit, in: Stolleis, Michael, Karl Härter, Lothar Schilling (eds.), Policey im Europa der Frühen Neuzeit, Frankfurt am Main: Vittorio Klostermann, 575-603

Friedman, Lawrence M. (1985), A History of American Law, New York: Touchstone

Glenn, H. Patrick (2005), On Common Laws, Oxford: Oxford University Press

Härter, Karl (1993), Entwicklung und Funktion der Polizeygesetzgebung des Heiligen Römischen Reiches Deutscher Nation im 16. Jahrhundert, in: Ius Commune XX, 61-141

Härter, Karl, Michael Stolleis (1996), Repertorium der Policeyordnungen der Frühen Neuzeit. Bd. 1: Deutsches Reich und geistliche Kurfürsten, Frankfurt am Main: Vittorio Klostermann

HallaQ, Wael B. (2005), The Origins and Evolution of Islamic Law, Cambridge: Cambridge University Press

Halpérin, Jean-Louis (2000), L'approche historique et problématique du Jus Commune, in: Révue international du droit comparé, 713-731

Haring, C. H. (1947), The Spanish Empire in America, New York: Oxford University Press

Heirbaut, Dirk (2003), Feudal Law: the Real Ius Commune of Property in Europe, or: Should We Reintroduce Duplex Dominium?, in: European Review of Private Law, 301-320

Hening, William Waller (1923), The Statutes at Large, Being A Collection of all the Laws of Virginia from the first Session of the Legislature in the Year 1619, New York: Bartow

Hughes, Paul H., James F. Larkin (1964), Tudor Royal Proclamations, vol. I: The Early Tudors (1485-1553), New Haven: Yale University Press

Hughes, Paul H., James F. Larkin (1969a), Tudor Royal Proclamations, vol. II: The Later Tudors (1553-1588), New Haven: Yale University Press

Hughes, Paul H., James F. Larkin (1969b), Tudor Royal Proclamations, vol. III (1588-1603), New Haven: Yale University Press

Hulsebosch, Daniel J. (2003), The Ancient Constitution and the Expanding Empire: Sir Edward Coke's British Jurisprudence, in: Law and History Review $21,3,439-482$

Jacobson, Stephen (2002), Law and Nationalism in Nineteenth-Century Europe: The Case of Catalonia in Comparative Perspective, in: Law and History Review 20, 307-347 
Kennedy, Duncan (2006), Three Globalizations of Law and Legal Thought: 1850-2000, in: Trubek, David M., Alvaro Santos (eds.), The New Law and Economic Development: A Critical Appraisal, Cambridge: Cambridge University Press, 19-73

Konig, David Thomas (1991), Colonization and the Common Law in Ireland and Virginia, 1569-1634, in: Henretta, James A., Michael Kammen, Stanley N. Katz (eds.), Transformation of Early American History: Society, Authority, and Ideology, New York: Alfred A. Knopf, 70-92

Konig, David Thomas (2008), Regionalism in Early American Law, in: Grossberg, Michael, Christopher Tomlins (eds.), The Cambridge History of Law in America: Volume I, Early America (1580-1815), 144-177

Larkin, James F., Paul L. Hughes (1973), Stuart Royal Proclamations, Volume I, Royal Proclamations of King James I, 1603-1625, Oxford: Clarendon Press

Libros registros-cedularios de Charcas (1563-1717), Buenos Aires: Instituto de Investigaciones de Historia del Derecho, 1992-1994

Libros registros-cedularios del Río de la Plata I-III (1534-1717), Buenos Aires: Instituto de Investigaciones de Historia del Derecho, 1984-1991

Libros registros-cedularios del Tucumán y Paraguay (1573-1716), Buenos Aires: Instituto de Investigaciones de Historia del Derecho, 2000

Nelson, William E. (1975), Americanization of the Common Law: The Impact of Legal Change on Massachusetts Society, 1760-1830, Cambridge, Mass.: Harvard University Press

Nelson, William E. (2008), The Common Law in Colonial America: The Chesapeake and New England, 1607-1660

Offutt, William M. (2005), The Atlantic Rules: The Legalistic Turn in Colonial British America, in: Mancke, Elizabeth, Carole Shammas (eds.), The Creation of the British Atlantic World, Baltimore: The Johns Hopkins University Press, $160-181$

Osler, Douglas (1997), The Myth of European Legal History, in: Rechtshistorisches Journal 16, 393-410

Petit, Carlos (1982), Derecho común y derecho castellano: Notas de literaturea jurídica para su estudio (siglos XV-XVII), in: Tijdschrift voor Rechtsgeschiedenis 50, 157-195

Pinlajamäкi, Heikкi (1997), La institución de la 'poena extraordinaria' y el derecho de la prueba en el derecho común y el derecho indiano, in: XI Congreso del Instituto Internacional de Historia del Derecho Indiano, Buenos Aires 4 al 9 de diciembre de 1995, Actas y Estudios IV, Buenos Aires: Instituto de Investigaciones de Historia del Derecho, 349-360

Pinlajamäki, Нeikкi (2002), Lo europeo en derecho: ius politiae y el derecho indiano, in: Derecho y administración pública en las Indias Hispánicas, Cuenca: Ediciones de la Universidad de Castilla-La Mancha, 1363-1376

Pinlajamäкi, Нeikкi (2004), La heterogeneidad de ius commune: Observaciones comparativas sobre la relación entre el Derecho europeo y el Derecho indiano, 
in: Actas del XIII Congreso Internacional del Derecho Indiano, San Juan: Asamblea Legislativa de Puerto Rico, 57-74

Pinlajamäki, Heikкi (2010), La invención del derecho indiano: las raíces cosmopolitanas de la disciplina, in: Revista chilena de historia del derecho 22, 583-592

Priest, Claire (2008), Law and Commerce, 1580-1815, in: Grossberg, Michael, Christopher Tomlins (eds.), The Cambridge History of Law in America, Volume I, Early America (1580-1815), 400-446

RaefF, Marc (1983), The well-ordered police state: Social and institutional change through law in the Germanies and Russia, 1600-1800, New Haven: Yale University Press

Ross, Richard J. (2008a), Legal Communications and Imperial Governance: British North America and Spanish America Compared, in: Grossberg, Michael, Christopher Tomlins (eds.), The Cambridge History of Law in America, Volume I, Early America (1580-1815), 104-143

Ross, Richard J. (2008b), Puritan Godly Discipline in Comparative Perspective: Legal Pluralism and the Sources of 'Intensity', in: American Historical Review $113,975-1002$

Scholz, Johannes-Michael (1996), Policía: Zu Staat und Gesellschaft in der spanischen Neuzeit, in: Stolleis, Michael (ed.), Policey im Europa der Frühen Neuzeit, Frankfurt am Main: Vittorio Klostermann, 213-297

Solórzano y Pereyra, Juan de (1648), Política Indiana, 5 vols., reprint Madrid: Atlas 1972

Stolleis, Michael (1992), Geschichte des öffentlichen Rechts in Deutschland, Bd. 2: Staatsrechtslehre und Verwaltungswissenschaft 1800-1914, München: Beck

Stolleis, Michael (1993), Geschichte des öffentlichen Rechts in Deutschland, Bd. 3: Staats- und Verwaltungsrechtswissenschaft in Republik und Diktatur 1914-1945, München: Beck

Stolleis, Michael, Karl Härter, Lothar Schilling (1996), Policey im Europa der Frühen Neuzeit, Frankfurt am Main: Vittorio Klostermann

Tau Anzoátegui, Víctor (1992), Casuismo y sistema: Indagación histórica sobre el espíritu del Derecho indiano, Buenos Aires: Instituto de investigaciones de historia del derecho

The Book of the General Laws and Libertyes (1648)

Twining, William (2000), Globalisation and Legal Theory, Evanston, Ill.: Northwestern University Press

Whitman, James Q. (2009), Western Legal Imperialism: Thinking About the Deep Historical Roots, in: Theoretical Inquiries in Law 10, 305-331

Zimmermann, Reinhard (1993), Der europäische Charakter des englischen Rechts, in: Zeitschrift für Europäisches Privatrecht 1, 4-50

Zorraquín Becú, Ricardo (1994), Hacia una definición del derecho indiano, in: Revista de Historia del Derecho 22, 405-417 


\section{The Theater of Conscience in the "Living Law" of the Indies}

In early September 1690, Juan Rodríguez, a royal notary, accompanied Spaniard Juan Moreno de Acevedo, owner of an obraje in Puebla, to an open field between the Indian towns of Santa Ana Acolco and Santa Bárbara Tamasulco, in the parish of Santa María Nativitas, Tlaxcala. Rodríguez had been charged by the audiencia in Mexico City with conducting a legal ceremony that was supposed to officially put Moreno into possession of the land as his own. On its face, this was to have been a routine proceeding. But all did not go according to plan. The audiencia had issued its order pursuant to a lawsuit between Moreno and the residents of Santa Ana and Santa Bárbara. In the late 1670s, Moreno had bought an hacienda adjoining the towns. He had then claimed certain lands as part of his purchase, lands which the towns insisted were theirs from "time immemorial," as one witness put it. Indian litigants relied on two sources to bolster their assertion: a map showing the boundaries of town lands and títulos y recaudos, or notarized documents, some in Nahuatl, dating to 1597 and establishing uncontested transmission from 1624 to 1663 . Moreno had first pressed his claim in 1679 , shortly after buying the hacienda adjacent to the towns. In 1682 he had obtained an order from the audiencia awarding him a particular piece of land, alleging that he had bought the parcel in question. Much litigation followed over the intervening years.

So when in early September the two Spaniards arrived at the site that Rodrigúez, in his notarial capacity, had noticed and were met by a group of indignant residents from Santa Ana and Santa Bárbara, there was a long history of suspicion between parties. In their September 1690 petition for a protective writ of amparo, the Indians stated that Rodríguez had noticed that the land on which they stood did not match the parcel described in the audiencia's order favoring Moreno. In the discharge of his notarial obliga- 
tion, Rodríguez had looked at the document describing Moreno's claim, noting boundary markers and other telltale signs, and had concluded that he could not match the description to the land on which he was standing. At that point, the two Spaniards had argued. After heated words, Rodríguez told Moreno that he would not "burden his conscience" by awarding the land erroneously. He refused to conclude the ceremony and left. He may have known that Moreno and the towns had been disputing this land for some time and that the Indians had long claimed to have possessed and cultivated it before Moreno bought the hacienda next door.

Temporarily thwarted by Rodríguez's act of conscience, Moreno sought another notary to execute the order and put him in possession. The officers from Santa Ana and Santa Bárbara then filed their September 1690 petition with the audiencia arguing that Rodríguez's initial refusal to proceed with the ceremony demanded the suspension of the subsequent order until the matter of which land was being referred to could be cleared up and the towns' legal claim settled. The audiencia agreed, rescinding its earlier order in favor of Moreno. To ensure the Indians were not dispossessed without a hearing, the audiencia dispatched a juez receptor, a judge with a special commission answerable directly to the audiencia, who ordered Moreno not to plow the land or bother the Indian residents, on pain of a 500-peso fine. This order would remain in place pending further litigation. ${ }^{\mathbf{1}}$

Such an explicit reference to an act of "conscience" in a legal proceeding was not common during this or any period of viceregal history, at least not in the documents I have seen. Indeed, this is the most explicit one I have found in an actual court record. ${ }^{2}$ Yet "conscience" was vital to the workings of law and justice in Spanish America. In any viable legal order, individual human beings must make judgments about how to act in relation to the laws, customs, procedures, rules, doctrines and facts that underwrite legal outcomes - whether awarding land, parsing contractual agreements regarding labor, property or money, interrogating witnesses, enforcing royal decrees governing political arrangements, making restitution, imposing fines, or determining the guilt and punishment of criminal defendants. This essay takes Rodríguez's moment of conscience seriously on its own terms. I see his

1 Agnt 127 (1a pte.).2 and (2a pte.).1. Ultimately, the town officials were awarded the land, but not until 1706. AgNt 226 (2a pte.).21.37.

2 The word did appear in other legal documents, especially testaments. 
refusal to proceed, and the reason he gave for it, as an occasion to think through the role and implications of conscience in the legal relationship between Spaniards and Indians, and between the king and his indigenous vassals in the New World. My chief aim is to see past the explicit rules, conventions or doctrines that governed everyday matters of law and focus on the spirit of judgment that animated relations between Spaniards and Indians in the context of imperial rule. I will also explore how that spirit was expressed in relation to and came to be challenged by the expanding role of self interest in social life between the sixteenth and eighteenth centuries.

My point of departure is Víctor Tau Anzoátegui's reaction against the modernist assumption that law can be understood chiefly in terms of its "systematic" qualities - explicit rules, procedures and legal norms as the baseline for how law works. Rather, Tau reminds us that law's role in a society depends as much on the "spirit" governing legal interactions as on the mechanics of a given legal arrangement. By "spirit" Tau means the "deep strata of a society's mentality and culture," its ideas, convictions and beliefs. A historical inquiry into the spirit of law demands that we attend to the ways philosophy, religion, morality, ethics, economy and politics are interwoven with technical issues of legality in a particular place, at a particular time, in a particular historical context. ${ }^{3}$ With Tau, thus, I see Derecho Indiano - the Law of the Indies - more as a yielding and adaptive framework than as a rigid structure of tightly mortised connections, at least - until the end of the Hapsburg period of Spanish imperial rule in the Indies.

Tau's seminal contribution to our understanding of Derecho Indiano is his distinction between casuistry and system. Employing these two "categorial concepts" - not quite ideal types - Tau argues that early Spanish imperial law was essentially casuistic, rooted not in abstract norms or doctrines, but in attention to the individual case and its particularities. He is as concerned with casuistry as a "social belief" underlying all legal thought and action as he is with casuistry as a specific hermeneutical device. Through the sixteenth and seventeenth centuries and culminating in the nineteenth century, Tau claims, this understanding of law gave way to a more system-oriented sensibility emphasizing technical matters and positive law over close attention to the peculiarities of each the peculiarities of each unique set of facts. 
According to Tau, we have misunderstood early law by assuming that the move from case-based casuistry to systemic positive-law represented a telesis from traditional to modern notions of law, often represented as a normative accomplishment of the European Enlightenment. This has made it almost impossible to engage Derecho Indiano on its own terms, for the "spirit," "beliefs" and "convictions" that Tau argues were at the core of legality in Derecho Indiano are largely bracketed out of discussions on contemporary systems of law. ${ }^{4}$

By looking to legal treatises, training manuals, primers, as well as philosophical, religious and political texts, Tau makes a powerful argument for seeing case-based casuistry as the means by which Spanish rule attended to the realities of the New World and its peoples. ${ }^{5}$ Legal decision makers were charged first with looking to the empirical and experiential side of transactions and disputes. Their duty was not to the law as such, or to any sense of abstract legal consistency, but to justicia, and specifically to producing just outcomes in light of all the circumstances. Each case was different and could not be otherwise; no rule could be universal because each case was a law unto itself - a medieval theological idea that can be traced back to Aristotle perhaps especially amidst the wild diversity of circumstances in the New World.

Though legal officers had to exercise conscience in all of their dealings whether deposing witnesses, disposing of civil lawsuits, judging guilt and punishment in criminal matters, or deciding whether and what to notarize Tau has little to say about conscience as such. Though he refers to "conciencia" in passing while discussing "the world of moral cases" and probabilism in the introduction to Casuismo y Sistema, and to "rectitude of conscience" as one of the requirements for a "good judge" in his final chapter, he does not develop conciencia as a theme. ${ }^{6}$ In this essay, I argue that conscience was a crucial animating force of Spanish imperial law and specifically of Derecho Indiano. For a time it represented a precept of right and just interpretation in the face of ever-present temptations to excess and self-dealing among the king's judges, corregidores, alcaldes mayores, receptores and notaries. In political and legal treatises and confession manuals, conciencia connected what was

4 I have made a similar point in Owensby (2008).

5 TAU (1992) 19 (quoting García-Gallo).

6 TAU (1992) 58, 60, 488. 
known as the fuero interior - the interior court of the soul's sense of right and wrong - to the fuero exterior of the soul's sense of right and wrong to the fuero exterior of positive law enshrined in royal decrees, ordinances and accepted legal practices and customs. As such, conciencia was part of the matrix of doctrinal and institutional restraints characteristic of Spanish viceregal legality, such as overlapping and competing jurisdictions, the right of appeal to the viceroy and the king and, crucially for the Indians, the ability to seek a protective writ known as the amparo, which effectively preserved a factual status quo until a full hearing on a matter could be held. ${ }^{7}$ While it is true that individuals often ignored conciencia, the fact that casuistry grounded legal thinking and practice in Derecho Indiano, as Tau argues, meant that proper conduct in accord with conscience was universally recognized as an obligation of all ministers of justice - even if many often laid their duty aside.

Conciencia, therefore, is better understood as a belief (creencia) - "a deep and elemental manifestation of facing reality, more vital than intellectual, of which little or nothing is said and which [is] considered to be a basic premise of the society" - than an idea announced and proven by means of a precise intellectual operation." ${ }^{\text {I }}$ think of conciencia as a self-effacing principle, a deep reflex expressing the conviction that ultimately men and their judgments, rather than unmediated impersonal norms, sustained the project of governing human communities. Following Tau, this reflex began to lose meaning as a new spirit of abstraction and distrust for casuistic thinking and its emphasis on the particular took root in the soil of European jurisprudence from the late seventeenth century onward, a process that ran parallel to the emergence of economic concerns at the core of all social and political thought.

\section{II}

As an intellectual, or at least definitional matter, there was little disagreement on the meaning of conscience among early-modern Spanish jurists. In 1611, Sebastián de Covarrubias defined conciencia as "knowledge of oneself,

7 On amparos, see Lira González (1971); Owensby (2008) chaps. 3-5.

8 Tau (1992) 39-40. See also Marías (1984) 233-245; Marías (1972) 123. Ultimately, the distinction goes back to Ortega y Gasset (1986). 
or certainty or near certainty of that which in our souls is bad or good." To be without conscience was to be "without a soul." To act without conscience was to have "no scruple."9 The Diccionario de autoridades published between 1724-1739 by the Real Academia Española retained this definition and commented that "[j] ust as nothing gives more life to hope than good conscience, so one of the things that most tears down [derrumba] and saps [desmaya] the vitality of hope is bad conscience." The Diccionario supplied a further gloss, noting that to "charge one's conscience" was to demand that a thing be done "with knowledge, rectitude and without trickery, malice or fraud. ... And so we charge the consciences of judges." ${ }^{\mathbf{1 0}}$

This connection between conscience and legal decision making was hardly new in the early eighteenth century. In his 1612 Arte legal para estudiar la jurisprudencia, Francisco Bermúdez de Pedraza argued that law - ius - was essentially homologous to conscience, for it was the "art, that is knowledge" of the good and the bad within society. This knowledge called upon legal decision makers to deal honestly with their fellows, live by a commitment not to harm others, and above all dedicate themselves to the idea that each person was entitled to that which was properly theirs (a cada uno lo suyo). While justicia rested firmly on these three pillars, a "constant and perpetual will" was necessary to ground the last of them, for justice was "a habit conceived in the soul of men." And though laws varied by time, land, and nation, said Bermúdez, justice was "one, constant and perpetual." Jurists and judges - and by extension all charged with producing binding legal effects were "true priests, not of the habit but of the soul, employing equity and justice" to defend the law - la ley - "fortress of the universe." Who would protect the poor, the orphans, the widows, the prisoners, the pilgrims if there were no law?, asked Bermúdez. Law was "the soul of the Republic" and jurisprudence the guarantor of "human happiness."11

In effect, every royal officer of the law and every churchman acting through the king's power under the Patronato bore a responsibility to see that justice was done. The will and obligation to justice lay especially heavy on those charged by training, vocation and duty with the defense of royal law. The Recopilación de 1680, the most authoritative and enduring legal

9 De Covarrubias Orozco (1674) 157.

10 Diccionario de autoridades (1969) vol A-C 474.

11 Bermúdez De Pedraza (1612) 12-13, 27. 
compilation of the period regarding Derecho Indiano, called all those involved with the law to be "men of good conscience," for the king had "unburdened the Royal Conscience" by assigning to his officers the duty to carry out the law with justice. ${ }^{12}$ For Castillo y Bobadilla in his Política para corregidores (1640), corregidores - royal officers at the front lines of justice in relations between Indians and Spaniards - should above all seek justice, because in doing so consisted "the service of God, the discharge of the king's conscience and the good of the republic." The monarch, after all, appointed judges, corregidores, alcaldes mayores, notaries and others because he was in no position to administer justice across the kingdom by himself. By these appointments he "discharged his conscience" in service to "the administration of justice." ${ }^{13}$ Failure to act in light of the royal conscience amounted to a kind of internal subversion of justice and thus of political order. As Jerónimo de Ceballos put it in his Arte real para el buen gobierno de los reyes, y principes de sus vasallos (1613), the "tribunal of justice" was the "firm chain and column on which rests the Empire, with which the good consonance and harmony of political government is assured, the master of political and social life ..." Aristotle had noted that the destruction of the Republic followed from a failure to maintain "justice," a "habit of the soul that conserves public utility" and enables the king and his officers to "resist ... the people of power in the Republic." As such, justice was the "joy of the afflicted, solace of the poor and unprotected and medicine for the soul" for it "humiliated the arrogant" and "lifted up the humble." ${ }^{\mathbf{1 4}}$ Law, in its broadest understanding, served as a counterweight to power within the social order. St. Thomas, noted Bermúdez, had made the point long ago: "The unbridled greed of men would pervert all things if justice did not check their appetites with the bit of its laws." 15

According to Friar Luis de León in his widely-read De los nombres de Cristo (1583), government by men could not match Christ's perfect government. Yet the spirit of the "living law" that characterized divine governance could guide human affairs, so long as men in positions of political power heeded

12 See Recopilación de leyes delos reynos de las Indias, 1680, (lib.tit.ley) 1.1.5; 1.6.28; 1.7.13; 1.7.30; 1.7.53; 1.19.1; 2.2.31; 2.3.8; 4.1.2; 5.5.2; 5.14.7; 6.2.9; 6.5.1; 6.10.7; 6.12.24; 6.15.7.

13 Castillo de Bobadilla (1750) 207, 222.

14 Zevallos (2003) 59r, 62v, 66v.

15 Bermúdez de Pedraza (1612) 12-13, 27. 
the pastoral call to care for those in their charge "according to the particular conditions of each one." ${ }^{16}$ Their job was not an easy one. Those who came to the law often told "lies and falsehoods to obtain their justice by trickery" and in no other arena than judging was "friendship" (amistad) so pressing and fickle. ${ }^{17}$ Hardly surprising, then, that so many - particularly New World corregidores and alcaldes mayores - were corrupt and self-serving. ${ }^{18}$ Indeed, the difficulties and temptations faced by all officers of the law in the Spanish Empire were widely acknowledged. Not only were the souls of individuals at risk; the republic itself faced genuine danger.

A sense of moral hazard hung over all legal affairs in the New World. Between the mid-sixteenth and the mid-seventeenth centuries, Friars Bartolomé de las Casas (Dominican), Alonso de Molina (Franciscan) and Jerónimo Moreno (Dominican) insisted that confessors attend to the "juridical character of confession" in deciding proper penitence for all ministers of justice who wished to ease their consciences, make their souls ready for communion and ensure their salvation. ${ }^{19}$ As legal historian Andrés Lira has argued, these men, writing from deep moral shock and political disquiet at the treatment of Indians by the Spaniards during the first century after conquest, opened the privacy of the confessional to the public realm by insisting that confessors withhold absolution from all who sinned against God by violating or ignoring positive law. ${ }^{20}$ Put another way, these three writers insisted on a vital connection between conscience and public obligation: to violate the law, or to fail to uphold it was to sin against God and absolution depended on heartfelt contrition and a willingness to right the wrong.

This connection expressed a well-established political idea: that the king's great task was to rule according to conciencia, implying the convergence of private and public concerns at the very core of political order. This notion pointed to a critical role for confessors. As Robert Bellarmine noted in his On the Duties of a Christian Prince Toward His Confessor (1513), "[n]ot without reason do we place the priest-confessor of the prince among those people

16 León (1917) 115.

17 Castillo de Bobadilla (1750) 137, 222.

18 See Solórzano y Pereira (1996) III, 1873-1874 (5.2.17/24/25).

19 Lira González (2006) 1139-1178.

20 Lira González (2006).

132 Brian P. Owensby 
whom the prince should consider as his superiors. For the priest, in hearing the confessions of the powerful (regardless of whether they are princes or private persons), acts as a judge in the place of God and has the power of binding or loosening in the sphere of conscience. ... [T] he prince's eternal salvation depends, to a remarkable degree, on his confessor." This was not merely a matter of contrition for private acts: a prince's confession solely to "sins that relate to him as a private person" is not a full confession if he "skips over the sins he has committed as prince." This implicated all of the king's officers, and especially those charged with dispensing justice. As Bellarmine noted, a king's confession to narrow sins of commission or omission should not satisfy if the confessor knows "how badly his administrators are behaving in administering the country."

Two notions followed from this proposition. First, the king needed to attend closely to what his officers were doing; he had a duty to ensure that they were behaving properly in the public, political realm, chiefly by obeying and enforcing the law justly. Second, all who operated with the color of the king's authority should be held to a standard of conscience that recognized their public role vis-à-vis the law. Lira puts it this way: "Conscience, beginning with the king's, was the premise and preoccupation of that public order in which Christian government was considered the only legitimate one and had to be on display at all times." 22 So when Las Casas in his Confesionario of 1545 demanded that confessors refuse absolution unless conquistadores and encomenderos made restitution for the harm they had caused the Indians, he was extending Bellarmine's point regarding the dual private-public role of the prince to all those in the New World who acted in the king's name or by the king's license. In effect, the fate of their souls depended on satisfying the demands of conscience by confessing and remedying wrongs made possible by the fact that they held office. ${ }^{23}$ The goal, of course, was that they obey and uphold the law, and thereby not succumb to sin; if they had sinned by violating the law, then they were obliged to make

21 From Bellarmino (2006) 223.

22 Lira González (2006) 1158.

23 Lira González (2006) 1151. Though Las Casas's document is generally known in the scholarship as the Confesionario, its published title was Avisos y reglas para confesores que oyeren confesiones de españoles que son y han sido a cargo de los indios de las Indias del mar océano. 
up for it. In practical effect, Las Casas was insisting that conscience have a role in everyday political life in a place where so many people - especially the Indians - were vulnerable to the wiles of the powerful.

Alonso de Molina took this notion one step further in his Confesionario mayor en lengua mexicana y castellana (1578), instructing confessants to consider their conduct after taking on some "office of lordship and governance." ${ }^{24}$ Confessors were to ask office holders seeking absolution whether they had issued unjust sentences or ruled against claimants because of a bribe or out of "greed."25 Such an officer was obliged to make good those who had been hurt. But Molina did not stop at the most banal sorts of wrongdoings. He held ministers of justice to a higher standard. Thus, a proper confessional "inquisition" would press penitent judges on whether they had "disturbed or impeded" petitioners from appealing or seeking justice at the audiencia, or had not received them "gently" with the intent of helping them, but instead "quarreled with them and dismissed them" so that they "would not dare to come before you." ${ }^{26}$ The soft sin of turning people away from law was just as erosive of justice as feckless inattention to the demands of office or the more hard-edged corruption of outright avarice. A confessant was always responsible for the state of his conscience, public as well as private, and so was obliged to "rectitude, justice and prudence" in all his affairs. ${ }^{27}$ In broader terms, this is what Barcelona printer Sebastián Cormellas meant in his dedication of Manoel Rodrigues' 1596 Summa de casos de conciencia con advertencias muy provechosas para confessores con un orden iudicial a la postre, where he insisted that anything that "benefits conscience aids the republic." 8

With the publication in 1637 of Jerónimo Moreno's Reglas ciertas y precisamente necesarias para iuezes y ministros de justicia de las Indias y para sus confesores, the process begun in the mid-sixteenth century that gradually bound conscience to positive law for those who held office and exercised power through the king's political authority reached its culmination. This is Lira's seminal point. In Moreno as in Las Casas and Molina, the confessional bridged the gap between private life and public. Among those concerned for

24 Molina (1578).

25 Molina (1578) 44r.

26 Molina (1578) 46v.

27 Molina (1578) 10v.

28 Rodrigues (1596). 
the plight of the Indians, this was a welcome development. Martín Acosta y Mezquita, audiencia lawyer and advocate for the poor and prisoners in Mexico City, wrote a foreword to the Reglas ciertas. Bemoaning the sad state of the Indians, he congratulated Moreno for his proposal that those charged with ensuring royal justice be held to account in the court of conscience. It was, said Acosta, a measured response to the fact that royal decrees had been so often ignored by those trusted with enforcing them. As Pope Pius V had once noted: "Grant me that confessors will do their jobs as they should and I will give you Christian government maintained in peace and tranquility." ${ }^{29}$ For Moreno, the temptations even of petty power in the New World were so great that "ministers of justice" were under a heavy burden of conscience and thus liable to confess even the smallest misstep in their relations with the Indians. This was not simply a matter of rendering judgment in cases at law. It touched every economic, contractual, adjudicative and administrative action ministers of justice might take under color of royal authority, from property agreements, to labor allocations, to tribute collection, to election mediations, to prices paid and charged pursuant to the repartimiento de mercancias. In all things, they were obliged strictly to observe the King's laws. So that even if he otherwise acted justly, a minister sinned by entering into any business or contract with his charges for his own benefit, because there was a royal decree forbidding it. ${ }^{30}$ The obligation ran further still. As Lira notes, Moreno's "First Rule" for confessors (of thirty) states that anyone who tells a minister of justice that he may legally have personal business dealings with the Indians is himself in mortal sin pending confession and restitution, because the law clearly forbids such dealings; enabling or even condoning sin was itself sinful, for otherwise ministers of justice would duck legal prohibitions by claiming that they had been assured in conscience by their confessors that they could act as they did. ${ }^{\mathbf{3 1}}$

For Moreno, mere procedural correctness was never enough to satisfy the spirit of the living law, rooted in natural and divine precepts, to which all ministers of justice owed their conscientious attention. This is what accounts

29 Moreno (1637). See also Mayagoitía (1996).

30 Moreno (1637) 19. And because doing so converted the relationship into one of private benefit rather than common good, a notion at odds with the fundamental pact underlying Spanish legality in the New World. See Owensby (2011) 59-106.

31 Moreno (1637) 2. Lira González (2006) 1163. 
for his references to the "fuero exterior" and the "fuero de la conciencia." In the sixteenth and seventeenth centuries, fuero referred broadly to the place where matters of law and justice were properly decided. Las Siete Partidas defined "fuero" as law properly used, something akin to jurisdiction. Etymologically the word derived from the Latin forum and according to Covarrubias it was equivalent to the Castillian plaza, "because trials and hearings were conducted in the most public places of the city and where there was the greatest congregation of people." ${ }^{32}$ In the early eighteenth century, the Diccionario de autoridades gave as a first definition of "fuero" the "law or particular statute of some kingdom or province" encompassing the "use and custom" characteristic of that place, pointing to the locative quality of all law. ${ }^{33}$ Covarrubias did not refer to "fuero de la conciencia" but Solórzano y Pereira did in the Politica indiana in 1648 and linked it to "mortal sin" and a duty of restitution (with regard to the obligation to pay tribute). The Diccionario de autoridades did offer an entry for "fuero de la conciencia," giving as a definition "the tribunal of reason, which directs and arranges the operations of man, absolutely according to divine and human laws." ${ }^{34}$ In essence, by distinguishing between the fuero exterior and the fuero de la conciencia, Moreno was making the point that public laws in the political world ultimately could not be meaningful instruments of justice unless those charged with keeping them were bound by an inner compulsion to abide by their spirit, not merely by their external formulation.

The crucial point, as with the notion of fuero generally, was that one could not be reduced to the other. The two fueros were intimately related, though ultimately each held to what was properly its own. The fuero exterior was the realm of positive law and royal decrees interpreted and applied by ministers of justice, where power and rights often butted heads. In the fuero de la conciencia the confessor was in charge and confessants answered to a higher standard of judgment. Thus, because "in the fuero exterior a sin can be absolved without absolving other sins" and "everyone should confess." For the "judge of the republic is a judge for the community, and so his judgment must be for the community, according to proof ... [B] ut the confessor is a

32 Covarrubias (1674) part. II, 19r-v.

33 Diccionario de autoridades (1969) vol 3-4 (D-N) 807.

34 Diccionario de autoridades (1969) vol 3-4 (D-N) 807.

136 Brian P. Owensby 
particular judge, next to God" As such, the confessor is charged not only with hearing the penitent's words but also attending to "particular knowledge" regarding the state of the penitent's soul. As Moreno pointed out, a minister of justice who has come to confess may not rely on the completion of a post-tenure residencia to claim that he is free from further demands, because "he is not free in the fuero de la conciencia" until he has made restitution to those he has harmed, regardless of the outcome of the residencia. This was true even if those harmed - usually Indians - had come to some sort of settlement with the outgoing officer, because such agreements tended to be "violent and against their will" or the result of fraud. ${ }^{35}$ And even if the residencia was entirely above board, confessants could not claim absolution merely by asserting lawful behavior; they owed an ineluctable duty of conscience to the spirit of the law in the fuero exterior.

\section{III}

This appeal to conscience can seem quaint, even quixotic at a time when it was commonly said that "self-interest accomplishes all." $\mathbf{3 6}$ Life, it struck many contemporaries in the seventeenth century, had become lonely, brutish, competitive and petty, an arena of "distrust and suspicion" in which there were no true friends because everyone was involved in a "perpetual war, without any sort of truce or peace" and each person pursued only "his own business and not the common and good of all." This was thought to be especially so in the New World, where Indians were the object of the Spaniards' (and others') manipulative fantasies and abusive energies. ${ }^{37}$ The point was not lost on the theological moralists who sought some way to ensure that royal officers were governed by conscience in their official lives. In a postscript to his Reglas ciertas, Moreno detailed the extent to which "unfaithful ministers of justice" "offended and aggrieved the majesty of God and of the king" by their treatment of the Indians. The majority of judges and ministers of justice did not confess because "their consciences did not gnaw

35 Moreno (1637) 12r, 18v, 47v, 49v, 50r, 51r.

36 Anon., Romance a México.

37 See Owensby (2008) 29 n. 68 (Calderón de la Barca, Darlo todo y no dar nada, act I); 29 n. 69 (Suárez Figueroa, El pasajero: advertencias utilísimas a la vida humana (1617), Saavedra Fajardo, Empresas (emblema 43)); 30 n. 72; 30 n. 73 (Romance a México). 
at them," a sign for Moreno of how unconcerned they were for the state of their souls and for the fate of the Republic. ${ }^{38}$

So why bother spelling out rules for confession in response to official misdoings if the people in question rarely confessed? For Moreno the answer was clear: far more than individual souls was at stake in the unconscionable behavior of corregidores, alcaldes mayores, tenientes and other ministers of justice on the ground in the Indies. By their conduct, such officers not only violated the king's law but sinned against the passion of Christ. They offered worse examples "even than the Gentiles," and by their "ambitions" and "greed" they threatened to "undo what the savior accomplished through his death." As a result, some "poor and wretched Indians (those who are Christians) abandon the faith, and those who are not Christians do not want to receive it," because those who have the "obligation of justice, to sustain and ennoble it with Christian acts" instead "discredit and dishonor it with pagan works, scandalizing [the Indians] with trickery, theft and the great blindness of greed," saying that "as they are Indians they are not Christians, and it does not matter if they are tricked and robbed." ${ }^{39}$ The individual souls of Indians and ministers of justice themselves were imperiled by such malfeasance, insisted Moreno.

Worse still, abuse by ministers of justice threatened the very fabric of New World society. If Indians fell away from the faith or would not receive it because of the mistreatment they suffered, the kingdom itself was at risk, for as Solórzano y Pereira noted, the king's indigenous vassals were liable to pay just tributes to offset the cost of "their evangelization and Christian governance." ${ }^{\mathbf{4 0}}$ If the Indians were driven away from the church by the misdeeds of judicial officers and others, the rationale for tribute became tenuous, at least in principle. Conciencia in Spain's imperial legal order, thus, should not be understood solely in terms of whether it was effective in restraining undesired behavior by individual officers of the law - often it was not. Rather, the concern for conscience expressed deep anxieties, about religious faith, good government, justice and right action in human affairs. At a time when human relations seemed increasingly instrumental and competitive, in a place where distant royal authority faced constant challenge by individual

38 Moreno (1637) 54r-59r.

39 MORENO (1637) 55v.

40 Solórzano y Pereira (1996) I 435 (2.19.2). 
interests on the ground and still-recent converts to Christianity struggled to shield themselves from the arrows of abuse that rained down on their lives, Moreno insisted that everyone be reminded of their obligations in the fuero interior. Yet this was not a strictly interior matter, as Castilllo y Bobadilla noted in his treatise on corregidores: Cicero had long ago pointed out that nothing was "more public, more rigorous and more faithful" than the "theater of conscience." ${ }^{41}$

Alonso de Peña Montenegro's Itinerario para párrocos (1662-63), written from Peña's judicial experience in Quito, suggests something of the intricate action that took place on this proscenium that thrust into the exterior drama of the New World. An instruction manual for priests of Indian parishes in New Spain, the Itinerario touches on every issue a pastor might face in ministering to his flock. The tome (running to over 500 pages), spared no ink in discussing the challenges of conversion, idolatry and witchcraft, of tribute and its collection, of justice among the Indians and between Indians and Spaniards, of the role natural law played in the lives of Indian subjects, and of the sacraments, including confession. It paid attention to the prickly relationship between locally powerful Spaniards - land owners, miners, alcaldes mayores and their tenientes - and vulnerable Indian parishioners. Conciencia ran like a bright thread through this tapestry of topics, reiterating the idea raised by Las Casas, Molina and Moreno that confessors were to hold all Spaniards to high standards in the fuero interior, especially those charged with specific duties by the king's law. Encomenderos had a duty of conscience to treat the Indians well, a principle enshrined in countless royal decrees. ${ }^{42}$ Judges of residencia were bound by conscience to hold ministers of justice fully accountable, and to demand full restitution for harm done. Those who failed to do so were "unjust judges," said Peña. Having accepted the obligation to "discharge royal conscience," they were "traitors to their Lord and King, carried away by interest and suborned by money" and so "approve injustices and dissemble abuses" of corregidores and alcaldes mayores. ${ }^{43}$

Such charges against ministers of justice were a logical extension of the fact that the New World's Indians were obligated in the fuero interior of law

41 Castillo de Bobadilla (1750) 418.

42 Peña Montenegro (1662) 242 (lib. II, trat. X, sec. II).

43 Peña Montenegro (1662) 249-250 (lib. II, trat. X, sec. X). 
as well as in the fuero exterior to pay just tribute. Peña was clear. To be "just", tribute had to be measured and proportionate to the ability of the subjects to pay, and always in relation to the benefits provided by the king, especially the administration of justice. ${ }^{44}$ As a consequence, the tributary obligation was not unqualified. Indians subject to excessive or unauthorized tribute exactions, or to "abuse and vexations" by encomenderos, corregidores, Indian caciques, or parish priests, could with "just and rightful title" flee their jurisdiction. Having fled, they were not bound in the "fuero de conciencia" to pay tribute they might otherwise have owed, for an abusive encomendero lost the right to demand tribute from his subjects (even if this meant loss to the Crown). ${ }^{45}$ Nor were these Indians, or hacendados or others who might receive them in another jurisdiction, liable to restitution of unpaid tribute in these circumstances.

Moreover, the Indians' decision to pay tribute, like any other judgment at law, was casuistic. A long-established doctrine held that those who in the fuero exterior were too poor bore no obligation, in law or in conscience, to pay tribute. The danger in this doctrine was obvious to Peña: if it were too easy for the Indians to claim poverty, "everyone would want to enter by this door and not pay tribute." Yet as natural law favored the poor, allowances had to be made for tributaries, and judges before whom they might appear had to consider "how poor they are." A man who could not feed and clothe his family, was under no compulsion, interior or exterior, to pay tribute. ${ }^{\mathbf{4 6}}$

There is a crucial point here. As Peña noted, obligation in the fuero exterior of the law was intertwined with an obligation in conscience, as much for tributaries as anyone else bearing a specific legal duty to the king. Tribute was a public matter - "chief nerve of the republic," according to Solórzano y Pereira ${ }^{47}$ - that made claims on the fuero interior of those under a burden to pay it. The burden of tribute was never absolute, for circumstances of abuse and poverty could justify non-payment. Even so, there is no doubt that decisions to suspend payment could be and often were instrumental. Yet as I have argued elsewhere, Indians involved in lawsuits made much of their tributary duties, embracing them to assert a kind of moral superiority over

44 Peña Montenegro (1662) 151 (lib. II, trat. II, sec. II), quoting Solórzano y Pereira.

45 Peña Montenegro (1662) 153 (lib. II, trat. II, sec. IV).

46 Peña Montenegro (1662) 150 (lib. II, trat. II, sec. I).

47 Solórzano y Pereira (1996) 3 2354-2355 (6.8.1). 
Spaniards, especially encomenderos, hacendados, corregidores and alcaldes mayores, who so often ignored royal decrees protecting the Indians. ${ }^{48}$ Indigenous litigants advanced such claims understanding that willing acceptance of their duties in ordinary circumstances gave them a certain credibility when the time came to bring grievances before a judge. Individuals or whole villages might go before a judge to complain of excessive tribute exactions, to claim poverty in periods of trouble, or to argue that changed conditions - often epidemics or flight from a village - made it impossible for them to adhere to previous rates and schedules. ${ }^{49}$ In doing so, they generally pointed to conscientious payment during normal times and expressed a desire to return to recognized and customary arrangements disrupted by the greed of local tribute collectors or to adjust their obligation to match their circumstances.

From Peña's perspective, Spaniards and Indians in the New World shared an obligation to act from conscience in matters of law, each according to his station in a hierarchy that bound all into a single political and moral project. Although it was established law by the seventeenth century that the Indians had the reason and discernment to exercise conscience, some Spaniards continued to contest the idea. For the most part, however, Spaniards and Indians alike appear to have recognized what conscience demanded. The Indians' status as men required it. And as Castillo de Bobadilla noted in his well-known Politica para corregidores (1640), addressed to all judges, governors, lawyers and "other public officials", there are "sparks of original flame" in all men, which Christians call "the dictates of conscience." At times, conciencia finds its path to virtue without "raciocination or acts of understanding," but for the most part it must be "regulated by reason, and not by absolute will, and is not free of the censure of a superior, nor can one who has the faculty to do an act, use it when the act is contrary to equity." ${ }^{\mathbf{5 0}}$ In other words, conscience inheres in all men and compels them to right thinking in judging and discerning right and wrong, but it is neither a guarantee of proper conduct, nor a license for arbitrary acts of will. "The chief intent and aim which the good Corregidor must have" - and by extension anyone else under an obligation to the law and justice - "is reverence for and observance of justice, as much in what he says and does as in that

48 Owensby (2008) 67, 87, 299.

49 Peña Montenegro (1662) 250 (lib. II, trat. X, sec. XI).

50 Castillo de Bobadilla (1750) 61, 241 (online). 
which he must judge in others, ... because in this object of justice rests the service of God, the discharge of the King's conscience and the good of the Republic." 51

For Peña and Moreno in the Indies, and Castillo as a more general proposition, conciencia lay at the very core of the political arrangement of society. It was a theological requirement, political principle and moral precept that had to obtain for society to live up to its divine purpose. Those who failed to live by its "dictates" - and there were many - violated the very essence of Christ's passion, betrayed the King and threatened the order and stability of society.

\section{IV}

In the Indies, where order depended on a delicate balance between the exploitation and protection of the king's indigenous subjects, conciencia was a critical belief that gave a spark of life to legal decision making at all levels. Rarely mentioned in everyday judicial proceedings, it was frequently invoked in legal treatises, confession manuals and the Recopilación, bridging religious notions of sin and obligation to the duties of law in the fuero exterior, where power and interest were in play at all times. By the seventeenth century, all of the king's subjects were bound by fearful and principled adhesion to the dictates of conscience in confronting the difficult choices implied in all affairs of law.

This is precisely what the representatives of Santa Ana and Santa Bárbara understood when they filed their petition in 1690 . By that time they had been in litigation for at least eight years over the land Moreno claimed. Their situation looked bleak, as Moreno had in hand an audiencia order awarding him the parcel and he was prepared to start plowing. They understood that as soon as he did they were almost surely lost. With crops in the ground and his farmhands living there, the towns would be unlikely to recover the land, given that productive use and occupation constituted prima facie evidence of proper possession. This was why the Indians hustled to the audiencia to stop Moreno from working the land. They invoked their status as "poor and powerless" people, "humble vassals and tributaries, who after our powerful

51 Castillo de Bobadilla (1750) 270 (lib. II, cap. II). 
God have no other protection.” They included with their petition a statement sworn out in late August 1690 by the local priest, bachiller (university graduate) Father Pedro Camacho de Campos Villavicencio who, in verbo sacerdotis, insisted that Moreno's claim was improper. The land abutted the Indians' church, said Camacho, "where we continually celebrate the holy sacrifice of the mass throughout the year" as had been done "from time immemorial," and it encroached on their cemetery, "where the faithful are buried." This amounted to a "grave offense against God our Lord and prejudice to the native Indians, who for so many years have lived and died as Royal Tributaries of your Majesty and residents of said towns." ${ }^{52}$ On the basis of this petition, the audiencia agreed to override its previous order and freeze the status quo. So it remained for the next decade and a half until a terse 1706 order awarded the towns the land that had been in dispute for over twenty-five years.

The turning point of the case had been Rodríguez's refusal to "burden his conscience" by following an order that did not describe the landscape before him. He could have executed the document in hand and been on solid legal ground. Many other notaries would have done so; Moreno found another who did. But Rodríguez said no and walked away. Of course, there were other plausible reasons for refusing to execute the order. Rodríguez may simply have wanted to avoid further trouble. He surely knew that the Indians would not stand idly by, given the history of this litigation, and he may have been worried about looking bad before the audiencia if he went ahead. At the very least he might have been summoned to explain his decision to proceed in the face of Indian resistance; not a pleasant prospect under any circumstance. A stand on conscience in favor of the Indians was unobjectionable at law and he may have anticipated that Moreno would do as he did - seek another notary to carry out the order - rather than complain to the audiencia about Rodríguez. This other notary may not have known much of the litigation and may have executed the order as a pro forma matter; after all, the audiencia had spoken, and more than once. Then again, he may simply have enjoyed greater moral flexibility than Rodríguez.

The explicit appeal to conciencia was not legally necessary for Rodríguez to walk away. He could have asserted the fact that the description did not 
match the land in question and suspended proceedings tout court. Yet Rodríguez's concern for conciencia was exactly what Lira says ministers of justice were under a theological and moral compulsion to do from roughly the mid-seventeenth century onward - worry about the fuero interior when acting as legal officers and understand that knowing error in the fuero exterior exposed them to penance and restitution. ${ }^{53}$ We have no idea how Godfearing a man Rodríguez was, or whether he confessed on a regular basis. As a royal notary he may well have been concerned, as his profession and duty required him to be, with doing right by the royal conscience. Though he probably had not reviewed the case record, he would have been familiar with the gist of the royal decree attached to a 1688 order favoring the residents of Santa Ana and Santa Bárbara. Citing sections of the Recopilación, that order stated that all officers of the king were obligated to "see to the Indians who suffer such great injustices and vexations ... for of all my vassals they are the ones who, by their tribute, most benefit and strengthen my Royal Crown." ${ }^{54}$ Nor was the outcome on that September day just a matter of Rodríguez's act. Indian petitioners chose to highlight Rodríguez's statement. In doing so, they were appealing not merely to the letter of the law, but critically to the spirit of judgment and right conduct underlying it: a Royal Notary of good conscience rejected Moreno's bald-faced, self-serving attempt at fraud. The contrast could not have been sharper, which probably was the point.

At least in theory, order and justice in the Empire depended on this contrast. We know that many did not hear the voice of conscience, or ignored it. The confessional was there to remind all who acted on behalf of the law that their decisions were not merely private matters and that there was no hard boundary between the fuero interior and the fuero exterior. So while many ministers of justice did not confess and many who did doubtless did so formulaically, the principle that conscience burdened all defined the limits of permitted malfeasance and enabled victims of mistreatment to seek redress, especially if they could claim to have abided by the demands of conscience themselves. In effect, conciencia was part of a yielding web of meanings and reliances that stood against unrestrained abuse. Corregidores,

53 We need far more research on how and the extent to which officers of the law were subject to penalties of restitution for wrongly decided cases.

54 AGNT 127.(2a pate.).1, 204v-205r. 
certainly, were the most prone to transgression, facing as they did the enticing vulnerability of indigenous people. Those further from the source of temptation, whose interests often ran against the open depredation of the Indians - such as ministers of tribute collection in Mexico City or Lima, royal notaries and judges of special commission - might be more receptive to conscience. For conscience never spoke in a social or political vacuum. It was an ethical baseline in a notoriously conflictual world characterized by the frequent disregard for legality and by unabashed self-regard, a belief and conviction linking each vassal's immortal soul to the operations of law, the idea of justice, the king's authority and the good of society.

If, as Lira argues, the private consciences of public officials became a matter of political concern during the seventeenth century, it was in response to a broad sense that the din of private interests - generally referred to by such words as codicia (greed) and interés (interest or self-interest) - was drowning out the law's voice on behalf of justice and good government. This disquiet was hardly new. In Spain and the Indies, the "universal confrontation of all, of some against others," as Maravall has argued, was characteristic of the long rupture between the Middle Ages and the emergence of a new, "modern" way of being in the world. ${ }^{55}$ For Tau, this was the same period in which casuistry, as a basis for legality, began to give way to system in Derecho Indiano. If older assumptions and understandings held through much of the seventeenth century, in part by insisting on the relevance of conscience, as Lira suggests, it was against the run of historical processes rooted in the growing commercialization of society as a whole from the fifteenth century onward.

By the middle of the eighteenth century, economic concerns had taken center stage in reformist debates within Spanish realms. The arbitristas of the late seventeenth century and early eighteenth century wrote chiefly about trade and the imperial fisc. Reformist minister José del Campillo y Cosio in his 1741 Nuevo sistema de gobierno económico para la América focused on economic structures and policies, and sought to recast the role of indigenous people in the Empire as the only viable basis for rescuing the imperial system from collapse. For Campillo, law was to be oriented toward "the good economy of the state" rather than toward the "political" and just governance 
of society - i.e., the "good order that is observed and kept in Cities and Republics, by enforcing laws and ordinances established for their good government." ${ }^{56}$ Without acknowledging it, perhaps because he could not grasp the full implications of his language, good government, once linked tightly to justice, had become a matter of "good order" above all. And if Campillo's prescriptions were thought extreme in 1741, elements of his economic program, and significant elements of his reasoning and his meanings, became common sense by the late eighteenth century in the context of the Bourbon reforms. ${ }^{57}$

Two documents written in 1749 in Peru hint at an indigenous perspective crosswise to Campillo's optimism that a "system of economic government" could displace justice in resolving the tensions of imperial rule. In the Verdadera relación y exclamación and the Breve y compendiosa satisfacción, Friar Calixto de San José Túpac Inca, who claimed descent from the last Inca, addressed himself in the form of a Lamentation and Jeremiad to the newly enthroned Ferdinand VI regarding the plight of the "American Indians." He catalogued the abuses of Spanish landowners, miners and officials, noting that the Indians, "innumerable vassals" and "most faithful subjects," had been abandoned by their King and Lord to the tender mercies of greedy Spaniards guided only by self interest. ${ }^{58}$ The answer proposed by Friar Calixto was not Campillo's turn to "economic government" but instead to shore up "law and justice" by cashiering Spanish corregidores and allowing the Indians to elect their own judges and conduct their own legal affairs, separate from the Spaniards - a jurisdictional solution. Only in this way could the Empire "put into practice a Christian, Catholic and proper justice, that is to say, law and reason" that would ensure the "souls of all [the king's] vassals, Spaniards as well as Indians." Thus would Spaniards "be relieved of weighty burdens of conscience," for though "they may gain gold and silver" by their self-regarding actions they are left with "heavy faults of conscience and

56 Campillo y Cosio (1789) 4; Diccionario de autoridades (1969) III 311-312. There has been some debate about whether Campillo wrote this tract. See Navarro García (1983); Navarro García (1995).

57 Artola (1952); Stein/Stein (2010) 231-259; Stein/Stein (2003); Tiryakian (1978) 233-257.

58 Clamor de los Indios Americanos $81(15 \mathrm{v})$. There is some debate about authorship of these two documents, though Friar Calixto was punished for them. See DueÑas (2010) $75-78$. 
soul." 59 In essence, where Campillo looked at a world of self-interest and concluded that the only solution was to give the Indians free rein or even force them to act from the same impulse, Friar Calixto took the view that justice pursuant to the royal conscience was all that could stand between the Indians and those who would trample them and call it good government.

Given the burdens economic processes and legal systems have imposed on vulnerable people in the modern age, perhaps Friar Calixto had a point. In the affairs of men, the voice of conciencia is never silent. But historical processes can produce understandings that drown it out, or make it sound thready and irrelevant in the grander schemes of human activity. This is one way to think about what happened between the sixteenth and nineteenth centuries, as Europe, both within and in its contacts with worlds outside itself, underwent the "great transformation" that brought economic systems to the center of social and political thinking. ${ }^{60}$ Acute observers - such as Las Casas, Molina, Moreno, Peña, Castillo and Friar Calixto - sensed what was happening without fully compassing it. They worried and offered tenuous solutions drawn from their understanding and experience. Actors such as Rodríguez and the residents of Santa Ana and Santa Bábara did the best they could in the theater of conscience to speak above the din of codicia and interés. They might have succeed in an individual case, but in the long run the stentorian voice of self-interest and economic imperatives carried the day in the political imagination - at least for a time.

\section{Bibliography}

AGNT - Archivo General de la Nación, Tierras (Mexico-City)

Anon., Romance a México. BN (Madrid), Mss. 19387

Artola, Miguel (1952), Campillo y las reformas de Carlos III, in: Revista de Indias $12,685-714$

Bellarmino, Roberto (2006), Roberti Cardinalis Bellarmini Opera Omnia, in: O'donelly, J.P. S.J. (ed.), Jesuit Writings of the Early Modern Period, 1540-1640, Indianapolis: Hackett

Clamor de los Indios Americanos 119 (44v-45r).

60 Polanyi (1944). 
Bermúdez de Pedraza, Francisco (1612), Arte legal para estudiar la jurisprudencia, http://books.google.co.in/books?id=k7R0F9RmuGAC\&printsec=frontcover\& source $=$ gbs_ge_summary_r\&cad $=0 \# \mathrm{v}=$ onepage $\& \mathrm{q} \& \mathrm{f}=$ false

Campillo y Cosio, José del (1789): Nuevo sistema de gobierno económico, Madrid

Castillo de Bobadilla, Jerómino (1750), Política para corregidores y señores de vasallos, Amberes

Clamor de los Indios Americanos, ed. Osorio C., F. Eduardo (1993), Mérida, Venezuela

Covarrubias y Orozco, Sebastián de (1674), Tesoro de la lengua castellana o española, Madrid, http://www.archive.org/stream/tesorodelalengua00covauoft\# page/n329/mode/2up

Diccionario de autoridades (1969), ed. Real Academia Española, Madrid: Gredos

Dueñas, Alcira (2010), Indians and Mestizos in the "Lettered City": Reshaping Justice, Social Hierarchy and Political Culture in Colonial Peru, Boulder, Colo.: University of Colorado Press

Peña Montenegro, Alonso de la (1662), Itinerario para párrocos, Madrid

León, Luis de (1917), De los nombres de Cristo, Madrid

Lira González, Andres (1972), El amparo colonial y el juicio de amparo mexicano (antecedentes novohispanos del juicio de amparo), México: Fondo de Cultura Económica

Lira, Andres (2006), Dimensión jurídica de la conciencia. Pecadores y pecados en tres confesionarios de la Nueva España, 1545-1732, in: Historia Mexicana 55:4 (abr.-jun.), 1139-1178

Maravall, José Antonio (1975): La cultura del barroco: análisis de una estructura histórica, Barcelona: Ed. Ariel

Marías, Julián (1972), La estructura social, Madrid

Marías, Julián (1984), Ideas y creencias en el mundo hispánico, in: Hispanoamérica, Buenos Aires, 233-245

Mayagoitía y Hagelstein, Alejandro (1996), Notas sobre las Reglas ciertas y necesarias para jueces y ministros ... de Fray Jerónimo Moreno, O. P., in: Anuario Mexicano de Historia del Derecho 8

Molina, Alonso de (1578), Confesionario mayor en lengua mexicana y castellana, México, http://libros.library.tamu.edu/book/oai:repository.tamu.edu:1969.1/ 94153/

Moreno, Jerónimo (1637), Reglas ciertas y precisamente necesarias para iuezes y ministros de justicia de las Indias y para sus confesores, México, http://books. google.com.br/books?id=YwHCePbfV0wC\&pg=PA7-IA2\&hl=pt-BR\&source =gbs_toc_r\&cad $=4 \# \mathrm{v}=$ onepage $\& \mathrm{q} \& \mathrm{f}=$ false

Navarro García, Luis (1983), Campillo y el Nuevo sistema: Una atribución dudosa, in: Temas Americanistas 2, 22-29

Navarro García, Luis (1995), El falso Campillo y el reformismo borbónico, in: Temas Americanistas 12, 5-14

Ortega y Gasset, José (1986), Ideas y creencias, Madrid 
Owensby, Brian (2008), Empire of Law and Indian Justice in Colonial Mexico, Stanford: Stanford University Press

Owensby, Brian (2011), Pacto entre rey lejano y súbditos indígenas. Justicia, legalidad y política en Nueva España, siglo XVII, in: Historia mexicana LXI:1, 59-106

Polanyi, Karl (1944), The Great Transformation: The Political and Economic Origins of Our Times, New York: Beacon Press

Recopilación de leyes de los reynos de las Indias (1681), Madrid: Ivlian Paredes

Rodrigues, Manoel (1596), Summa de casos de conciencia con advertencias muy provechosas para confessores con un orden iudicial a la postre, Barcelona

Solórzano y Pereira, Juan de (1996), Política indiana, Madrid

Stein, Stanley J./Stein, Barbara H. (2003), Apogee of Empire: Spain and New Spain in the Age of Charles III, 1759-1789, Baltimore: Johns Hopkins University Press

Stein, Stanley J./ Stein, Barbara H. (2010): Silver, Trade and War. Spain and America in the Making of Early Modern Europe, Baltimore: Johns Hopkins University Press

TAu Anzoátegui, Víctor (1992), Casuismo y sistema: Indagación histórica sobre el espíritu del Derecho Indiano, Buenos Aires: IIHD

Tiryakian, Josefina Cintrón (1978), Campillo's pragmatic New System: a mercantile and utilitarian approach to Indian reform in Spanish colonies of the eighteenth century, in: History of Political Economy 10:2, 233-257

Zevallos, Gerónimo de (2003), Arte real de buen govierno de los reyes, y príncipes de sus vasallos, Madrid: Centro de Estudios Políticos y Constitucionales 



\section{Víctor Tau Anzoátegui and the Legal Historiography of the Indies}

1. Truth be told, it is always difficult to conduct any kind of historiographical analysis. Now, where the task does not only entail the works of a contemporary author, but the works of an author who is both a significant intellectual reference point and a personal friend of the analyst, the task becomes ever more difficult. I confess that such is my situation in regard to Víctor Tau Anzoátegui and his works. So, though aware of my limitations, I assume the responsibility I took on when I was invited to participate in this collective work. More specifically, I will attempt to share a critical and comprehensive analysis of what his ideas and contributions imply within the legal historiography of the Indies. Thus, I shall not address the remainder of his prolific output of scientific writing. I would also like to clarify that, besides the fact that I am not in a position to treat all of his contributions thoroughly here, I shall not attempt to provide the reader with a catalogue of his fruitful intellectual work. I have a different objective: attempt to outline the central aspects of the historiographical thinking of this renowned Master, whose studies have, for decades, attracted the attention of his colleagues and of many others interested in recreating the Spanish American past both in the Americas and in Europe. As regards the author and the role that he plays within this discipline, I believe that the same words that Tau himself dedicated to García-Gallo when making an account of his intellectual background can be rightfully applied to him as well; i. e., that the Argentine legal historian also has an "outstanding profile", given that he has drafted various works on method and guidance which have contributed "decisively to the setting of guidelines within the discipline." Similarly, it can be truly asserted that, as a researcher, he "critically welcomed the legacy of previous scholars and developed new criteria, most of which received academic consensus", and that we owe him "sharp analyses that covered different theoretical perspectives, with no opponents of his stature, except for partial disagreements."

1 Tau Anzoátegui (1993) 9. 
It is appropriate to describe Víctor Tau as a legal historian who understands Law as the expression of a way of seeing the world, that is, a legal tradition. This is his natural observatory. Now, it is worth recalling that as a member - possibly, the most prominent - of what can be identified as the third generation of great experts in the history of the Law of the Indies - the same generation that reviewed and went beyond the guidelines set by the two highest exponents of the first generation, Rafael de Altamira and Ricardo Levene, and the most renowned of the second generation, such as GarcíaGallo, Alamiro de Avila Martel and Ricardo Zorraquín Becú -, Víctor Tau Anzoátegui has excelled as an intellectual leader for several decades. Certainly, that suffices to warrant a piece of writing such as this. Nonetheless, my desire to elucidate the guidelines of his legal-historical criteria also responds to another reason and has a very specific goal: helping to cover, at least in part, the deficit in self-reflection that the legal history of the Law of the Indies has. This discipline, despite its relative theoretical weakness, currently spurs considerable academic interest, and is continuously and constantly nurtured by large amounts of varied monographs.

2. As for the praise received by the works of Víctor Tau, I understand that their main impact results from his creativity in the proposal of new topics and the treatment of areas that were left behind by ancient masters and colleagues. ${ }^{2}$ Far from intending to make a thorough record of this kind of contributions, I can underline, from among his original concerns and reconsiderations, the detailed analysis of the set of sources of Law; his preoccupation for the local and concrete practice of normativity; his early and clear awareness of the integration of the Law of the Indies into the intellectual framework of the European legal tradition. In fact, a key aspect of the legal historical thinking of Tau has been his flexible notion of what must be considered Law of the Indies. In this regard, he has affirmed that "against a classical, unitary, rigid image of the Law of the Indies imposed from the Peninsula, there arise new images of a multiple, unbounded Law of the Indies, stemming from the different regions of the New World, in accordance with the diverse geographical and human realities of the vast continent." ${ }^{3}$

2 For an example see Tau Anzoátegui (1980) 331 and 332.

3 Tau Anzoátegui (1997) 85. 
However, I must regret that his fine style has not always bore fruit as expected. Thus, among what Tau himself described as "uncharted profiles", I understand that the set of his very subtle and valuable conceptual creations like "oscillations" 4 or "satellite-texts", not yet become an integral part of the consolidated lexical tools that I believe he can still provide to academia. Besides, I must also admit that I personally do not always agree with his opinions. Far from sharing his assertion that "the bans of good government take the most popular place within the legal system," ${ }^{\mathbf{6}}$ I tend to think the opposite.

Apart from the foregoing, it must also be stated that Tau's work stands out, again and again, due to his concern to verify the points of view outlined initially, and because of his honesty at the time of warning on the potential weaknesses of the evidence offered. Thus, there have been plenty of opportunities in which he engages in a dialogue with his readership on the difficulties experienced. By way of example, when he presented his works on the customs of the Indies, and after warning that "in successive studies during the last 25 years" he "gradually [noted that the] Law of the Indies increasingly differed from contemporary Law in its conception and structure," he did not fear to admit that the recreation of American customs demanded of him "an arduous task, not always explicitly expressed, not always along safe paths."

Besides, while one of his concerns has been to replace the ancient legalist focus of the legal system of the Indies for one based on the notion of legal tradition $^{\mathbf{8}}$ (a goal derived from the conviction about anachronistic deviations imposed by 20th century dogmatism), his historiographical endeavor is also featured by a fascinating intellectual exercise, where the subtle and intelligent use of the most varied sources ${ }^{9}$ coexists with a formidable rigor and accuracy in the delimitation of the objects of study and the exposition of results. ${ }^{10}$

4 Tau Anzoátegui (1977) 88.

5 TAu Anzoátegui (2004) 18.

6 Tau Anzoátegui (2004) 22.

7 Tau Anzoátegui (2001) 14.

8 Tau Anzoátegui (1997) 43.

9 Tau Anzoátegui (1997) 88.

10 Cfr., for example, Tau Anzoátegui (1977) 86. 
3. Now, as important as the foregoing may be considered, I do not find it the most distinguished of Tau's contributions. In my opinion, there are other more relevant aspects. His propositions have fostered and encouraged research by others more than once, to a certain extent, because they are courteously open to academic debate, and because they are noted for the formulation of manifold conclusions defined by a provisional factor ${ }^{\mathbf{1 1}}$ inherent in the conviction that no scientific research can ever be considered a "close" piece. ${ }^{\mathbf{1 2}}$

I would like to point out that several of the distinctive features of Tau's works are along the lines of those of the most salient exponents of the Law of the Indies traditional scholars, especially in the formulation identified with the members of the so called School of Levene. Among the most important features of this line of historiography, it is worth stressing the insistent heuristic concern mentioned above, and the firm conviction that a true understanding of legal phenomena requires the integration of past Law into an ample framework of complex socio-cultural expressions; thus, the constant concern of the Argentine Professor to link legal history and social history. ${ }^{13}$ It is precisely based on this conception of the nature of legal phenomena that Tau affirms, among other considerations, that "Law accepted as such by the political authority or by jurists has a scope of influence and application that hardly ever reaches all the corners of society." ${ }^{14}$ Likewise, as a consequence of such outlooks, which integrate Law into the social fabric, our author admits: "I would like to draw attention to an approach that recognizes laws as social events and which, after establishing laws as one of the mechanisms for the creation of the Law, verifies their coherency and tension with the other sources, confirms the presence of social and political forces in their origin and enforcement, notes their unique manners of application, observes their use and lack of use, unveils social acceptance and resistance mechanisms, examines their presence in legal proceedings, notarial records, literature and daily conversation." Thus, "questions arise: what is the role played by jurists within this process and to what extent do laws support the growing strength of state power; do laws reflect social aspirations;

11 Tau Anzoátegui (1980) 333.

12 Tau Anzoátegui (2000) 123.

13 Tau Anzoátegui (1992b) 4 and 5.

14 Tau Anzoátegui (1997) 24. 
do they propose goals, principles, standards; are all social groups aware of their provisions, or is this awareness limited to legal experts? These are some of the questions that ought to make laws a matter of joint concern by legal historians and by political, social, economic and cultural experts, among others", each addressing such questions from their special viewpoint. ${ }^{15}$

Another frequent feature of Víctor Tau's research style is his fine selection of the materials and the clear examinations to which they are subjected. Our author has recognized his "interest in researching into the notion of justice of a certain author does not have a mere academic purpose, of intellectual delight, for sheer academic speculation. Without underestimating this aspect, my purpose is to examine the use of this notion in legal practice. And thus verify to what extent scholarly contributions are accepted, appreciate how such notion operates in the arguments of jurists, and observe the value given to it in the then prevailing mindset. To that end, it is necessary to consider that casuist thinking, which is twisted in itself, requires notions and rules to support the formulation of particular solutions. The absence of strict tenets within the legal system led to the appreciation of certain notions such as justice, which has played a key role as a guide, end and limit at the same time." 16

4. Strictly speaking, and although at present he may be the historian studying the Law of the Indies most concerned in defining and specifying a sound and original conceptual-theoretical framework, his scientific program has not always been presented within a neat organic structure, even despite Tau's manifest tendency on the matter. ${ }^{17}$ Therefore, it can be argued that a considerable portion of his thoughts on program and method are more or less scattered through his works. Among the notes that are most repeated within such work, his rigorous analytical attitude is worthy of mention. Thus, far from indulgent and excessive praise, Tau has undertaken to "introduce the scalpel of criticism" 18 more than once, urging his counterparts to "come out of the narrow environment where Dogmatism has enclosed the notion of Law, disregarding all spheres of normativity not estab-

15 Tau Anzoátegui (1992b) 5 and 6.

16 Tau Anzoátegui (1992c) 609.

17 Tau Anzoátegui (1997) 13.

18 Tau Anzoátegui (1997) 8. 
lished by the written law of the State. Such a restrictive conception cannot be applied to our Law of the Indies, nor to other legal systems of the time." ${ }^{19}$

Tau Anzoátegui's recognized sharpness benefits from the fact that many of his thoughts have been enhanced after long analysis and the subsequent revision of his lucid initial propositions. That is to say, that his style stands out because of valuable and sustained intellectual endeavors. Such is the case, among many others, of the process that he finalized after two decades with the publication of his organic work on the bans of good government. ${ }^{20}$ Based on his disciplined and continual formulation of ideas, perspectives and interests, the works of Tau are defined, more than by "surprises", by the pre-announcement of a series of hypotheses which, having undergone corrections and adjustments, tend to conclude into firm global statements. It can be said that his intuition brings about numerous unique studies, which, eventually, enable him to formulate suggestive and appealing global recreations of the legal past. Thus, he explains, for instance, and I believe that with some degree of exaggeration in terms of their randomness, that the works that make up La Ley en América hispana [Law in Spanish America] did not respond to "a previous plan, but rather, arose in isolation, fostered by various intellectual concerns and realized through academic commitment." ${ }^{21}$ Besides, endowed as he is with an acute sense of appreciation of the value of the different historical evidence, Tau benefits from the smallest traces offered by the wide set of documents that he has gathered in his multiple and fruitful incursions into archives.

5. I understand that the key of his thoroughness resides, above all, in the exercise of a constant and considered preoccupation, especially the firm preoccupation with conceptualizing the legal-historical processes of the Indies. Of course, Tau can thus only reject simplifying schemes, ${ }^{22}$ even those endorsed by the best-established tradition in the discipline. Hence, for example, his concern to disentangle the normativity of the Indies led him to overcome the once-respected, distorted and retrospective legalism to contend that the Law of Spanish America was integrated into an order in which

19 Tau Anzoátegui (1997) 22.

20 Tau Anzoátegui (2004) 15.

21 Tau Anzoátegui (1992b) 18 and 19.

22 Tau Anzoátegui (1992b) 12. 
custom had a prominent role, ${ }^{23}$ and to extol the virtues of legal scholars in their role as "directive source" within the Spanish American legal culture. ${ }^{24}$ In the same sense, he has stressed that while "the rejection of downgrading the Law of the Indies to the Recompilación [Compilation] or to peninsular legislation has frequently been noted by ancient and modern masters of our discipline," such criterion has not always been applied, "at times, even by themselves." 25

All in all, Tau Anzoátegui's works and activity stand out for a ubiquitous and considered preoccupation with the activity of legal historians, and the need to "encourage the renewal and expansion of the content of our discipline." ${ }^{26}$ Consistent with his condemnation of any kind of "implied" historiographical theory, ${ }^{27}$ more than once Tau has made the effort to introduce "among us, in an organic fashion, and with a view to methodological debate and gradual acceptance", several thoughts on the appropriate approach to understanding the Law of the Indies. Against this backdrop, he has noted that "review is a claim common to all disciplines and times, but in certain opportunities, it is a pressing issue," and he has endorsed setting out precise "general guidelines" which will allow "fixing new [disciplinary] scopes with further clarity." 28

To a certain extent, Tau's rigorous theoretical preoccupation benefits from his frequent - and intelligent - readings of the best legal historiography. Nonetheless, the latter was impossible on several occasions, such as when he decided to address topics lacking an adequate monograph base.

Tau himself has described his style in Casuismo y Sistema [Casuistry and System]: "at the outset and during the course of this research - he comments - I have borne in mind the ideas put forward and the possibility of their multiple usefulness. That has decisively encouraged me to put them into action. For a long time, I have gathered the material that I use as support, and in the last years I have intensified searches, chiefly in Spanish libraries and archives. As presumed, testimonial evidence is scattered throughout numerous ancient, printed and handwritten documents. Often, the value

23 Tau Anzoátegui (1992b) 9.

24 Tau Anzoátegui (1992c) 609.

25 Tau Anzoátegui (1997) 88.

26 TAu Anzoátegui (1997) 128.

27 Tau Anzoátegui (1992b) 3.

28 Tau Anzoátegui (1997) 7 and 8. 
of such evidence lies in discovering the spirit underlying the words. There are no thematic indexes or files that facilitate the search. Though I have always pursued to select writings or examples that are representative and sufficient to minimize an error in judgment, this does not prevent other testimonies or new interpretations of known texts from taking to standpoints that may soften or directly contradict the opinions I state. Far from exhausted, the research I present remains open to new searches and reflections." ${ }^{29}$

Certainly, the extraordinary academic dissemination enjoyed by Tau's works is connected to the most distinguished historiographical tradition of the Law of the Indies. However, there is evidence of an unbiased and critical perspective, which has encouraged him, more than once, to overcome ancient disciplinary paradigms ...

In Tau's view, previous historiographical products make up an important disciplinary intellectual capital. Nonetheless, that does not prevent him from suggesting the careful employment of accepted paradigms, and of what he considers model investigations. ${ }^{30}$ In this regard, Tau says, generically, that "our studies, in continuous formation, have a gradual progress - not linear or conformist - through the contributions of successive generations. Thus, when we look back to the past of our discipline, we do much more than an act of evocation; instead, we engage in a necessary exercise of introspective knowledge of our activities, both cumulative and critical, which eventually leads us to consolidate the current foundations of our work." ${ }^{31}$ Hence, there is an imperative need to foster new approaches to the discipline, especially after noting the persistence of stagnant legalist views, ${ }^{32}$ and the inappropriate "application of the set of sources of Law in the formulation of monographs of the Indies." 33

Based on the preceding arguments, I believe that in the future, to a good extent, the works of Tau shall bear the responsibility to fulfill a prediction analogous to the one conveyed by Altamira to Levene in their time: "It is possible to believe that in some years colonial history will differ radically from what has been revealed up to the present time." ${ }^{34}$

29 Tau Anzoátegui (1992a) 14.

30 Tau Anzoátegui (2000) 121.

31 Tau Anzoátegui (1990) 475.

32 Tau Anzoátegui (1997) 41.

33 Tau Anzoátegui (1997) 47.

34 Tau Anzoátegui (1990) 483. 


\section{Bibliography}

Tau Anzoátegui, Víctor (1977), El abogado del Cabildo de Buenos Aires durante el virreinato, en: Academia Nacional de la Historia, Bicentenario del Virreinato del Río de la Plata, Buenos Aires, t. 1, 85-104

Tau Anzoátegui, Víctor (1980), Consideraciones sobre la aplicación de la Recopilación de 1680, en: Revista de Historia del Derecho 8, 331-395

Tau Anzoátegui, Víctor (1990), Altamira y Levene: una amistad y un paralelismo intelectual, en: Cuadernos del Instituto de Investigaciones Jurídicas (México) $15,475-492$

TAu Anzó́tegui, Víctor (1992a), Casuismo y sistema. Indagación histórica sobre el espíritu del Derecho Indiano, Buenos Aires: Instituto de Investigaciones de Historia del Derecho

Tau Anzó́tegui, Víctor (1992b), La Ley en América Hispana. Del Descubrimiento a la Emancipación, Buenos Aires: Academia Nacional de la Historia

Tau Anzoátegui, Víctor (1992c), La noción de justicia en la Política Indiana de Solórzano, en: Homenaje a Ismael Sánchez Bella, Pamplona: Eunsa, 609-619

Tau Anzoátegui, Víctor (1993), El tejido histórico del derecho indiano. Las ideas directivas de Alfonso García-Gallo, en: Revista de Historia del Derecho 21, 9-72

Tau Anzoátegui, Víctor (1997), Nuevos horizontes en el estudio histórico del Derecho Indiano, Buenos Aires: Instituto de Investigaciones de Historia del Derecho

Tau Anzoátegui, Víctor (2000), Las Indias iprovincias, reinos o colonias? A propósito del planteo de ZorraquínBecú, en: Revista de Historia del Derecho 28, $77-137$

Tau Anzó́tegui, Víctor (2001), El poder de la costumbre. Estudios sobre el Derecho consuetudinario en América hispana hasta la Emancipación, Buenos Aires: Instituto de Investigaciones de Historia del Derecho

Tau Anzó́tegui, Víctor (2004), Los bandos de buen gobierno del Río de la Plata, Tucumán y Cuyo (época hispánica) (Edición y estudio), Buenos Aires: Instituto de Investigaciones de Historia del Derecho 



\section{Between America and Europe The Strange Case of the derecho indiano}

\section{The right to memory and lost identities}

On December 15, 2010, the United States recognized the Universal Declaration of Indigenous Populations. Their recognition followed the one of Canada, Australia and New Zealand thereby reinforcing the hopes of those who considered the Declaration to be an important instrument for the defense of indigenous populations and the reparation of the wounds inflicted on them by history. ${ }^{\mathbf{1}}$ It is common knowledge that the Declaration was approved by the General Assembly of the United Nations in 2007 with the unfavorable vote of the United States, Canada, Australia, New Zealand and the abstention of 11 countries. It was not easy to obtain the approbation of all members because of the resistance of many states to recognize the native populations who lived in their own territories as nations holding collective rights. ${ }^{2}$ As a matter of fact, already in 1982 a special working group composed of representatives of the indigenous populations was formed at the Sub-commission on the Prevention of Discrimination and the Protection of Minorities. In 1993 the Working Group on Indigenous Populations prepared and presented to the Sub-commission an initial project that was approved one year later. ${ }^{3}$ It seemed that everything was going well but after the

1 The Announcement of the United State's support for the United Nations Declaration on the Rights of Indigenous Peoples was given by President Obama during the Tribal Nations Consultation in Washington, D. C.

2 United Nations Declaration on the Rights of Indigenous Populations, 13/12/2007, http:// www.un.org/esa/socdev/unpfii/en/declaration.html.

3 The Working Group on Indigenous Populations is an organ created by the U. N. Economic and Social Council, and it is part of the Sub-Commission on the Prevention of Discrimination and Protection of Minorities. The Project was approved by the Sub-Commission with the Resolution 1994/45 (26/8/1994). With the same resolution the Sub-Commission had also submitted the draft to the U.N. Human Rights Commission. On 29/6/2006 the 
approval the project got lost in the U.N. corridors and it appeared again many years later. It is a long story, but I neither want to reconstruct it nor confront the theoretical and practical problems it entailed. ${ }^{4}$ I will take instead the Declaration as a starting point for a more general consideration on derecho indiano and on the research prospects it might suggest to jurists and legal historians.

The Universal Declaration of Indigenous Populations is based on memory. It assumes the defense of memory as an instrument for the definition of indigenous identity and the protection of indigenous rights. The individualization of a new legal subjectivity, the indigenous people, a collective subject whose full right to self-determination is recognized, is possible only by recognizing their right to manifest, practice, teach their cultural traditions, celebrate their spiritual and religious ceremonies, pass on their history, their culture and their language to future generations. In the text there is no definition of indigenous people. This should not astonish us since it was not contained in the project of 1993. In fact it was not necessary. This new subject did not need any definition because it did not ask for state recognition or legitimation. It is not necessary because it is already given, it is a historical subject that existed before the states. But it claims, precisely through the use of memory, the preservation and reinforcement of its political, social and legal system. ${ }^{5}$

draft was adopted by the Human Rights Council but the U.N. General Assembly adopted the Declaration only on September 13, 2007 (Resolution 64/295) with 143 votes in favor, 4 against it (Canada, Australia, New Zealand, United States) and 11 abstentions. The protection of the indigenous identity is a right already recognized in 1989 by the ILO Convention 169 (Convention Concerning Indigenous and Tribal Peoples in Independent Countries). It was the first treaty concerning the protection of indigenous rights adopted by the International Labor Organization and ratified by 27 states.

4 See Nuzzo (2002); Nuzzo (2011).

5 In 1983 Martinez Cobo, special rapporteur of the U.N. Sub-Commission on the Prevention of Discrimination and Protection of Minorities, Study of the Problem of Discrimination against Indigenous Populations, U.N. Doc. E/CN.4/Sub.2/1983/21 Add.1-7 (1983) wrote that the community, the people and the indigenous nations are those who "having a historical continuity with pre-invasion and pre-colonial societies that developed on their territories, consider themselves distinct from other sectors of societies now prevailing in those territories or parts of them. They form at present non dominant sectors of society and they are determined to preserve and develop and transmit to the future generations their ancestral territories, and their ethnic identity, as the basis for their continued existence as people." 
In order to exist again as a people it is necessary to be able to remember. But remembering is not memory. It is part of the distinction with which memory works. The other issue is forgetting. As a matter of fact memory is based on a series of selective operations of remembering and forgetting. As Raffaele De Giorgi wrote, the memory is the unity of the distinction between remembering and forgetting. ${ }^{6}$

Remembering and forgetting are the distinctions through which memory works and at the same time we could say, with a certain simplification, they are the two poles around which both the issue of indigenous peoples' claim for identity and the discourse of colonialism have been structured and from which, in the course of time and in different ways, strategies of assertion or denial of indigenous subjectivity have been developed. In other words, outside of memory, remembering and forgetting become the conditions that make the existence of an indigenous legal subject possible or impossible. Only memory of oneself and of one's own history can produce identity and thus subjectivity. On the contrary, those who lack memory or those whose memory was stolen or overwritten do not exist. Franz Fanon reminded this very effectively many years ago opening a meeting on the relationship between national culture and fights for freedom. According to Fanon the colonial dominion had produced a "cultural obliteration." In other words it disconnected the subjected peoples from their culture denying the local reality, introducing new juridical relationships and producing their systematized subjection. ${ }^{7}$ The consequences were dramatic. The consciousness of the impossibility of becoming white or of eliminating the "hated negritude" led to wrong-footing of the colonial ego, to the irreparable schizophrenia of identity. Many years later in the post-colonial debate the uncertainties about identity became a foundation of power. ${ }^{\mathbf{8}}$ The reconstruction of one's past through a long and painful process of re-memorization on the one hand confirmed the impossibility of rejoining one's original identity; on the other hand it was a tool for imagining a new hybridized subjectivity in which the identity of the colonized and of the colonizer melted. Thus it became impossible to overcome the conflict between the "colonial self and the colonized other" and at the same time to establish both the mutual dependence of the

6 De Giorgi (2004) 142-61.

7 FANON (1971) 61.

8 Fanon's central position in post-colonial studies is declared by CHakrabarty (2000) 17. 
two once opposing identities and their continuous fluidity. Paradoxically subaltern studies revealed the deepest violence of global capitalism exactly at the moment when its strategies confirmed the uniqueness of the world and gave a peaceful representation of it, based on the dialectic relationship between opposite concepts of center and periphery. They built a theory of subalternity that, starting from Gramsci's concept of hegemony, overtook the binary logic of first world / third world, colonizer/colonized and passed from the dialectic self/other to the dissemination of the images of the self and of other. The result was a new subjectivity, precisely a hybridized one, residing in the body of a new protagonist upon which colonial modernity had built its reasoning and that asked to be the maker of its own history. ${ }^{9}$

The political battle for the recognition of one's own diversity and one's own right to memory imposed therefore new approaches to historiography. This last one entrusted with the task of revealing the inadequacy of legal and political categories of Western thought in order to favour the comprehension of the world's complexity, and the relationships of power pre-existing its use, thus determining the selection of facts to be told and the way in which they had to be narrated. ${ }^{\mathbf{1 0}}$ At the same time the methodological renewal produced by decentralized forces coming from post-colonial and subaltern studies overcame the special and theoretic limits of the previous historiography and allowed us to make more complex narrative canons of Western historiography and the discursive practices of international lawyers. ${ }^{\mathbf{1 1}}$

However, there is a still a lot to be done, as the strange case of the derecho indiano seems to confirm.

\section{Claiming an Identity: the Road Map of García Gallo}

The editors have suitably called this volume New Horizons of Spanish Colonial Law, but what does hide behind the expression "Spanish Colonial Law"? What does it hint at, or what is its equivalent in Castilian? The most immediate translation, derecho colonial español is not of great help. No specialist in Spain or Central and South America would recognize the subject of their

9 The existing literature is already endless: Bhabha (1994); Prakash (1994); Prakash (1995) 4 ff.; GuHa (2002).

10 Mezzadra (2008) 56-72.

11 Craven (2008); Nuzzo (2012). 
studies in this translation. We might say that Spanish Colonial Law is the politically correct version of a legal discipline that is well-founded in the Hispanic academic tradition: the derecho indiano.

Anyhow, it is not easy to provide a definition. It seems easier to say what the derecho indiano was not: it was not an indigenous law. Carlos Petit maliciously defined it as the exotic version of ius commune, and Bartolomé Clavero, more polemically, a "derecho generado o reconocido por parte de Europa para dicha geografía y dicha humanidad, como si ésta careciera de cultura y así de capacidad para regirse por sí misma, así como para determinar la reglas de recepción y acomodamiento de la gente sobrevenida y extraña de entrada para ella." ${ }^{12}$ In any case it was a European law that on one hand the legal historiography imagined to have arrived in America with the first conquistadores, on the other hand it was used to tell the story of the West Indies in the same way as the legal history of European countries had been told.

Moreover, the expression derecho indiano itself was the result of an invention. It was absolutely unknown to the 16th, 17th and 18th centuries' jurists who used the expression derecho de las indias or de los Reynos de Indias. On the contrary it was invented by the Argentinean Riccardo Levene, leading scholar of the Argentinean school of legal historians, and founding father of the discipline together with the Spanish in exile Rafael Altamira. ${ }^{13}$ According to Levene the derecho indiano had to be identified with all the law in force in the West Indies. It was an extremely rich prescriptive set of provisions of a different origin and nature that met in a single system able to "organizar el gobierno espiritual y temporal de las indias, establecer la condición de sus habitantes, regular la navegación y el comercio y sobre todo convertir a los indigénas a la fé católica." ${ }^{14}$

But the loyalty to the idea of system and the sharing of the aims that the derecho indiano would bring about did not prevent the historiographic representations offered by the doctrine from being univocal. Simply put, one might say that until the end of the 1970s (or rather until Alfonso García Gallo's positivistic approach undisputedly prevailed) the system of derecho

12 Petit (1993a) 665; Clavero (2004-2005) 543.

13 On the relationship between Rafael Altamira and Ricardo Levene, see TAu Anzoátegui (1997a).

14 Zorraquín Becú, cited in Tau Anzoátegu (1997b) 33 (ft. 19). 
indiano was based on the supremacy of Castilian legislation and on a certain image of the Spanish monarchy in which from the outset the signs of a modern state were there to be seen. Then, with the end of Francoism, the fading of García Gallo's star and Spain's entrance into Europe it was also possible to rediscover the legal and customary elements of the medieval legal experience. At the same time Spanish legal history started to be included in the history of ius commune and the common European juridical tradition. ${ }^{15}$

I will begin with García Gallo. The legal history in Spanish speaking countries is characterized by his activity on the Iberian Peninsula as well as in Latin America and by his extremely rich scientific contribution. ${ }^{\mathbf{1 6}} \mathrm{He}$ was able to make himself responsible for Edoardo de Hinojosa y Naveros' heritage, mythicizing his figure, acting as his pupil and at the same time methodologically criticizing his work and his school. He took upon himself the burden of projecting a new history of law, thinking of it in the first place as a legal-scientific discipline, in which the legal historian is both a jurist and a scientist. The first images of this renewed history of Spanish law as a juridical science were collected in two works published between 1948 and 1952 dedicated to Hinojosa. The first one introduced a complete re-edition of the latter's work and the other was the result of a conference held at the Instituto nacional de estudios jurídicos, and the following year published in the Anuario de historia del derecho español. ${ }^{\mathbf{1 7}}$

The methodological change that García Gallo called for was not simple: he had to introduce Edoardo de Hinojosa y Naveros' work, commemorate the hundredth anniversary of his birth and at the same time trace out the guide-lines of his own history of law. He had to impose a turning point in Spanish legal historiography through a deep renewal of the conceptual instruments it used. At the same time he had to hide the changes in his own point of view inside a discourse and a representation that, both on a political and legal level, focused on continuities more than fractures. ${ }^{\mathbf{1 8}}$

15 Nuzzo (2008).

16 On García Gallo's role at the Instituto internacional de Historia del Derecho Indiano founded in Buenos Aires in 1966 with Ricardo Zorraquín Becú and Alamiro de Avila Martel, see Martiré (1996).

17 García Gallo (1948); García Gallo (1953b); a critical analysis of the relationship between García Gallo and Hinojosa in Vallejo (1998).

18 These fractures were evident in García Gallo (1941), where he criticized Hinojosa's thesis on the Germanic component of Spanish law expressed in Hinojosa (1910). 
The history of law was a legal science that needed its own methodology in order to be told. This on the one hand would free legal scholarship from political constraints, and from the economic and more generally the sociocultural context. On the other hand it would prevent singling the jurist out as the main partner of the legal historian. Moreover, the legal historian was also a jurist and as such felt the duty to remove his subject, the law, from the influence of other disciplines and in particular freeing it from cultural contaminations that would alter its identity and it is precisely identity the issue.

Whilst reconstructing the route through which the legal systems and the institutions had developed, García Gallo did not speak of medieval law, but rather of a present law that regulated the daily aspects of social life. Thus he entrusted the historian with the delicate task of remembering and selecting which were the element for constructing the memory and identity of the jurist and the country and what, once again, was to be condemned to oblivion.

The problems the legal historian had to face with dealing with the issue of derecho indiano were not different. Also in this case the re-definition of disciplinary identity continued to be his main aim. Moreover, while in Spain García Gallo had identified Hinojosa as the founder of the discipline, thus contributing to mythicize his profile and presenting himself as his heir, in Central and South America the absence (from his point of view, obviously) of a school which complied with a strict legal method, took him to propose himself as the true founder of the derecho indiano. ${ }^{19}$

At the beginning of the 1950s García Gallo adjusted his strategy. He exalted the role of law as a legal source in the 16th century Indies and subjected the methodologies used by the legal historians when studying the derecho indiano to severe criticism. ${ }^{20}$ Even if he recognized Rafael Altamira's and Ricardo Levene's centrality and their importance for the discipline, the approach of the two scholars, with their openness towards history,

19 See Tau Anzoátegui (1992b); about García Gallo’s beginning as an Americanist historian see the critical analysis of Clavero (2007).

20 The articles are: La ley como fuente del derecho en Indias en el siglo XVI (1951); Panorama actual de los estudios de historia del derecho indiano (1952), and El desarollo de la historiografía jurídica indiana (1953), all published in García Gallo (1972a). In the following years he often turned to treating methodological problems reaffirming the already expressed theses or refining his positions. Particularly useful: García Gallo (1967); García Gallo (1971); García Gallo (1972b). 
sociology and politics, had inexorably jeopardized the subject of their studies. According to García Gallo they lacked legal sense, the recognition of the centrality of the legal dimension and the will to study it "con espíritu y técnica de juristas." 21 "La vocación histórica o sociológica de la mayor parte de los cultivadores estudiosos de la Historia del derecho indiano les lleva a atender a los fenómenos sociales con olvido de los propiamente jurídicos y a no valorar estos en su propio alcance sino con criterio extraño al derecho. La construcción dogmática, que constituye la tarea principal de los juristas científicos - se ocupen del derecho romano, medieval o del actual - apenas se ha intentado. [...] El estudio dogmático perfectamente compatible con el histórico del derecho indiano, tarea que incumbe a los juristas y no a los historiadores está sin hacer [...]. La Historia del Derecho debe ser para el jurista un modo de conocer el Derecho, y no la Historia o la sociología. Por ello ha de estudiarse con orientación, espíritu y técnica jurídica."22

An historian of derecho indiano has therefore to engage in the discovery of his identity as well as the one of his discipline and contribute to build a national conscience by reconstructing the history of its "national positive law." Also, since the law had its identity, it was necessary to read it being aware of its evolution, forgetting the historical and social concern and limiting the attention to political, social and economic aspects. ${ }^{23}$ Consequently the history of the derecho indiano (too long entrusted to historians, at the expense of jurists' attention) also had to be considered as a scientific discipline since the law, being a subject more than a simple technique, was a true

21 García Gallo (1967) 112. But already in García Gallo (1948) CX he reiterated Altamira's "sociological concern" that "relegated law to a secondary level" and that "he was no researcher of Hinojasa's kind." To this point Vallejo (1998) 778 writes "Un investigador del tipo de Hinojosa de García Gallo es lo que Altamira claramente no era. No es que relegase Altamira lo jurídico a un segundo plano, sino que defendía una posición metodológica que entendía que hacer la historia del derecho implicaba bastante más que hacer la historia, estrictamente del Derecho; y no se trataba entonces de hacer sociología, sino de seguir haciendo historia del Derecho sin perder de vista sus manifestaciones y condicionantes más diversos."

22 García Gallo (1952) 55 ff. He confirmed these positions nineteen years later: García Gallo (1967) 112.

23 García Gallo (1967) 107-119. The quoted paragraph is taken from García Gallo (1972b) 1078. He confirmed these positions in the review of Paradisi (1973) and criticized the methodological opening it contained: García GaLLO (1974) 741-752; a comparative lecture of the methodological positions of García Gallo and Paradisi in D’Ors (1977). 
science. Lawfulness, being a neutral and evaluating knowledge capable of translating general values into laws and juridical concepts, was based on the distance which separated it from the violent world of politics and socioeconomic struggles, and its capacity to build and represent itself as a unique, closed and self-referential system, capable of recognizing its own trueness. The derecho indiano was therefore essentially a legislative system. ${ }^{24}$

In a territorial organism that, just as it happened in 16th century in France, assumed the form of a state where the main theologians, jurists and political thinkers took an active part in the process of absolutistic and bureaucratic centralization, the law seemed the most apt instrument for the realization of the sovereign's will. It also enabled the renewal of the sovereign' s centrality and it was at the same time the clearest instrument of civilization. ${ }^{25}$ Thus, on the one hand the positivistic tension and the state aspirations introduced a functional legal paradigm to read, from a unitary point of view, any discourse on power and on political subjects as well as those not institutionally active in the Indies.

On the other hand the legalistic dimension in which the Conquista was absorbed allowed historiography to introduce a break between the desires of the monarchy for the defense of the rights of the natives and its constant insistence on their evangelization and the violent reality for the Indian population. The laws of Burgos and Valladolid, the Leyes Nuevas, the Ordenanzas of 1573 (to give only the most renowned examples) translated the religious concerns of the sovereigns, reflected Ferdinando and Isabella's promises to Alessandro VI and initiated a virtuous network between three poles: the imperial chanceries and the jurists of the Crown, the universities and the theologians of Salamanca, the Indian territories and indigenous

24 In the Indies the concept of law, after being initially identified with the norms in force in the Reign of Castile and automatically bestowed overseas, in the years immediately after the Conquista absorbed both the ordenanzas, le cedolas, le reales provisiones, le instrucciones and the cartas issued with a general character for all overseas countries, those addressed to a province as well as to a certain place. In both cases, for García Gallo the Indian provisions were a special law put on top of a hierarchic scale of sources that could be integrated in a unique system by a subsidiary Castilian law, defined general or common. García Gallo (1951); García Gallo (1967); on this issue see Tau Anzoátegui (1992d).

25 Pietschmann (1980). As regards Italian legal historiography, that up to the 1980s was not very attentive to the relationship between law and politics in 16th century Spain, see Piano Mortari (1987). 
populations. Christian yearnings, political reasoning and juridical logic competed in the definition of their status allowing Morales Padrón to see in the Burgos laws "el primer cuerpo básico del estatuto indigena” and García Gallo to justify up until the 1970s the co-existence, in this fundamental prescriptive body, of the recognition of human nature and freedom of the indigenous population while maintaining the system (of exploitation) of the encomienda. ${ }^{26}$

\section{Claiming an identity: Francesco Calasso and the system of ius commune}

The construction of a national legal identity and the project of a methodological renewal of the history of law followed by García Gallo demanded the recovery and the exaltation of the institutional profiles as well as the legislative activity carried out by the sovereigns of Castile. Yet in order to achieve these objectives it was necessary to undertake a deep change in the mindset in the way the role performed by Roman law in Spain and its heritage was perceived.

Spain, under the dictator Franco, imposed a proudly different (legal) history from the European one. It was a Christian and nationalistic history focused on the primacy of legislation and of state; a history where the juridical literature had a secondary role and where only an echo of the ius commune could be heard. Through the ley de las sietes partidas, the great drawing up of Alfonso X in 1265, the Romanist and canonistic tradition had also entered the reign of Castile and from there the West Indies. But as a consequence of a precise political strategy aimed at the territorial unification, it had become a common law with national character

In Spain, as García Gallo maintained in a conference held in Rome in the middle of the 1950s and published in the Revista de studios politicos, the ius commune for the first time passed through a crisis highlighting its incapacity to offer appropriate answers to the new needs. The American experience then pitilessly revealed its inadequacy. ${ }^{27}$ Its principles, he continued, were used to

26 Morales Padrón (1979) 308-310; García Gallo (1977) 755-756.

27 García Gallo (1955). The Revista de estudios politicos, at which García Gallo during the 1940s collaborated assiduously, was the organ of the Instituto de Estudios Politicos, the ideological laboratory of the regime, founded in 1939 following the model of the Istituto italiano di cultura. 
incorporate the Indies into the Crown of Castile and to define the juridical titles which legitimized the dominions. But when the ius commune reached the Indian coasts, through the Requerimiento, its weakness became evident and the scornful answer of two Cenú caciques was enough to cause the whole system to be debated. ${ }^{\mathbf{2 8}}$

As Fernandéz de Oviedo remarked, after reading the document, the two Caciques denied the validity of Alexander VI's donation and consequently the legitimacy of the dominion claimed by the Spanish sovereigns and confirmed their inalienable rights on those territories. García Gallo imagined them and represented them to us as "firmes en sus convicciones jurídicas" and considered their answer "consciente y concluyente: la validez del derecho común fue rechazada y a él opuso el propio derecho indígena." The consequences of this gesture were enormous. "Por primera vez se negaba al derecho común su vigencia universal y se le rechazaba en la resolución de los problemas del Nuevo Mundo." ${ }^{29}$

In the damp forests of Cenú and for an audience, as the Italian one, with little familiarity with the Indies, García Gallo put an inglorious end to a universal juridical knowledge, heavy with triumphs in Europe, and at the same time stressed that the insufficiencies of ius commune had also caused a beneficial "Spanish reaction." And this time the answers were both adequate and immediate. On a doctrinal level Francisco de Vitoria had substituted the ius commune with the "system" of ius gentium and on a legislative level the Crown had issued important legislation inspired by systematic tensions and the Christian dimension of the old ius commune which had recognized the principles of freedom and independence of the autochthonous populations.

I am not sure whether Francesco Calasso, the legal historian of "La Sapienza University", had also been invited to the meeting at the Spanish Institute of Rome that day and, if he had been sitting among the audience, what he might have thought about the sad destiny García Gallo reserved to ius commune or about his legislative approach to legal history. García Gallo's

28 The Requerimiento too had a state character. In fact García Gallo (1955) 157 writes that "este Requerimiento, pleno de amenazas a quien lo aceptase, tampoco era distinto del que cualquier Gobierno actual, antes de emplezar la fuerza, hace a cualquier grupo de sediciosos para que acaten el poder establecido"; on the discursive strategies of the Requerimiento see Nuzzo (2004) 13-85.

García Gallo (1955) 158. 
discourse (particularly his attention towards national identity and the extensive use of the term system) enabled us to reconstruct the threads that connected the Spanish professor to the Italian legal culture and particularly the influence exercised by his system of ius commune. Even if the García Gallo's project of methodological renewal had imposed the re-evaluation of the role played by ius commune or presupposed its complete nationalization, it still needed the idea of a system introduced, by Calasso to endow the medieval juridical experience with a scientific character and to connect ius commune and iura propria.

Certainly the differences were not negligible. García Gallo's theoretical construction, simply based on the binomial law and nation, was far from the refined doctrine of Calasso. Moreover, both shared the objective of redefining the identity of the discipline and using legal history as an instrument for the construction of a national juridical identity. Calasso's historiographic proposal required the recovery of the historical authenticity of medieval law and the reconstruction of the economic, political and social relationships in which the juridical texts and their authors were immersed. It was no longer the time for a "history of Roman law during Middle Age" as Savigny had done, for old contrapositions between Romanists and Germanists (or Italianists) nor for sterile exercises of dogmatic reconstruction. As a matter of fact, in the Middle Ages "a new spirit" had already taken possession of the old body of Roman law, and put new energies into it and determined a deep transformation unifying that law with "its own experience", its needs and "rivivendolo ed esaltandolo come norma del proprio operare“.$^{\mathbf{3 0}}$ Roman law was no longer the hard core of the medieval juridical experience, but rather the ius commune and the historian of Italian law was its authorized cantor. It was not only a problem of discipline or an academic struggle aimed at achieving more room for the history of Italian law inside the law faculties. Examining the historicity of ius commune meant considering the existence of an Italian law free from the Italian state and recognizing an Italian juridical identity before the national unification. ${ }^{31}$

Following Santi Romano's institutionalist theory, Calasso identified law with the legal system and sustained its plurality. "La constatazione della pluralità, però, come ha scritto Pietro Costa, non era per Calasso la conclu-

30 Calasso (1954) 33; Calasso (1939); see Conte (2009) 27-32.

31 Iglesia Ferreirós (2000). 
sione dell'indagine, ma la sua premessa; serviva a porre correttamente un problema, che per Calasso è il problema rispetto al quale le considerazioni 'istituzionalistiche' sono strumentali: questo problema è il problema dell'unità." ${ }^{22}$ As a matter of fact, according to Calasso, the construction of a national legal history required the reassembling of a plurality of norms inside a unitary system. The ius commune united the histories in one great Italian history seeming to be a system of systems. At the same time Croce's idealism and Romano's theory itself did not allow Calasso to break free from the images of state and law and led him to consider the system of ius commune as a legislative system, or at least to consider the legislative component as the prevalent one. ${ }^{33}$ The history of ius commune was now the "storia di questo sistema unitario, e non soltanto del diritto romano comune, e meno ancora della scienza del diritto o della giurisprudenza. Chè infatti, scienza e giurisprudenza furono l'organo potentissimo della evoluzione del sistema: ma essendo questo un sistema legislativo, la posizione dommatica dell'attività del giurista $\mathrm{o}$ del giudice vi rimase sempre ed esclusivamente quella di attività interpretativa, sul fondamento logico e giuridico, e quindi con tutte le norme e i limiti che ogni attività interpretativa può avere in un sistema legislativo." ${ }^{34}$

Thus Calasso understood the historicity of medieval law and stressed its specificity with regards the Roman law opposing at first the dogmatic approaches of Pandectistic school and then the neo-pandettistic revival of the 1950s. Moreover, in order to transform that "new" law into a scientific knowledge and into an instrument to legitimate a discipline in search of redemption inside the European academy, he needed to recover Savigny's notion of system. Furthermore, Calasso could not but use the system. Independently from its legislative and doctrinal connotation it was not identified with a logical principle necessary for the exposition and the organization of the subject matters, or with a historic product functional for a precise political juridical project. On the contrary, it was on one hand a constitutive principle of law and it was impossible to set it aside without losing the scientific nature and the truth of one's own discourse and of one's own

32 Costa (1999). Paradisi (1980) remains fundamental.

33 Paradisi (1980) $217 \mathrm{ff}$.

34 Calasso (1939) 129; see also Calasso (1948). Costa (1999) 38 uses the above quoted paragraph. 
subject; on the other hand, it was an interpretative model good for selecting the heterogeneous prescriptive materials that it should be able to coordinate and build upon the reality it was to describe. ${ }^{35}$

In 1951 - the same year when some fundamental works that Calasso had dedicated in the 1930s to the problem of ius commune were collected in a well-known volume called Introduzione al diritto commune - an essay by García Gallo on the concept of law and its role inside the system of sources in 16th century Indies appeared. The Spanish scholar did not miss the Italian editorial novelty quoting it and recommending it to his pupils as a fundamental lecture. ${ }^{36}$ He needed those pages for the construction of a unitary and scientific concept of derecho indiano. They gave him the conceptual framework to keep the old Castilian law and the new law issued for the overseas territories together. As a matter of fact his theoretical representation did not need a ius commune neither as Roman law nor as law produced by the jurists' interpretation. In the first case because the Roman law had already been nationalized; in the second case because Calasso himself had already streamlined its creative dimension. Moreover, the theoretical representation of García Gallo was freed both from historicity and spirituality in which Calasso had instead immerged it because any historical and religious tension had already been selected and made positive. Thus, only two prescriptive systems remained in opposition: Castilian and Indian, and with them the "old" problem of unity. ${ }^{37}$ This made Calasso's work still useful. The solution was in those pages, in the idea of the system that he theorized and in the idea of the state he still evoked. Castilian laws and laws for the West Indies, like ius commune and ius proprium were the elements that inside a state framework, in a dialectic tension between the general and the particular, and between common and special, were able to intrinsically and organically connect in a unitary system. ${ }^{\mathbf{3 8}}$

35 Mazzacane (1998).

36 "El primer libro que me hizo leer fue el Medioevo del diritto de Calasso" stresses Villapalos (1996) 14 reminding the first teachings he got from García Gallo.

37 On the relationship between Calasso and the philosophic culture of idealist roots AJELLo (2002) $118 \mathrm{fff}$, $400 \mathrm{ff}$.; from a different point of view also Iglesia Ferreirós (1999b) insists on the problem of unity.

38 García Gallo (1951); García Gallo (1971) 177: "el ordenamiento juridíco no es tan sólo un conjunto de normas, sino uno auténtico sistema regido por principios y desarrollado de modo armónico.” 


\section{Claiming an Identity: Carl Schmitt and the Discovery of the New World}

The end of Franco's regime and the overcoming of the nationalistic approach of Spanish historiography made first the re-discovery of ius commune possible and then enabled its projection onto the West Indies, imaging there the existence of a unitary and organic system. It was based on the dialectical relationship between the general and the specific, as it also seemed to happen in the respublica christiana.

Before following the ius commune during its transoceanic journey I think it is time to dwell upon the editorial news that was published in Europe at the beginning of the 1950s. While Calasso was re-writing the history of medieval legal thought through the concept of ius commune and García Gallo was including the Spanish Indies within a legislative, Christian and nationalistic system, the German jurist Carl Schmitt published Der Nomos der Erde im Völkerrecht des Jus Publicum Europaeum. ${ }^{39}$ In this book he turned again to international law and, following the same spatial approach to policy that had marked his work in the Twenties, traced the history of the ius publicum europaeum from its beginning to its dissolution. ${ }^{40}$ Schmitt's history not only described Europe's lost identity under the blows of Kelsen's formalism and legal universalism, whilst taking the relationship between Ordnung and Ortung as a narrative archetype. It also expressed the desire for new amity lines and with them the desire for a new nomos and a new process of space subdivision.

The American claims of a new Western hemisphere, the equalization between colonial territories and national territories, the move (following the peace conference in Paris) from a European order to a universal one, the turn of a discriminatory concept of war and of the pre-modern identification between enemy and criminal, had produced the dissolution of the inter-European state system through which the international relationships had been juridically organized for four hundred years. It saw in territorial

39 Sснмiтt (1950a).

40 See especially Sснмітт (1940); Sснмітт (2005). Schmitt's interest in international law increased during the 1930s, see the articles Sснмiтt (1995) edited by Maschke; on the meaning of Großraum in Schmitt see Schmöckel (1994) $124 \mathrm{ff}$.; CarTy (2001); on the relationship between geopolitics and Schmitt's Großraum see Losano (2010) 59 ff.; Galli (2010) 864-877. 
states its protagonists and in the discovery of a new world its pre-condition. The voyages of Columbus allowed Europe to know a free and unlimited space that was ready to be textualized and occupied. The Bulls of Alexander VI were the instruments for achieving these aims: they confined the American territories and the Ocean within a legal text and enabled the Landnahme of the Catholic powers, Spain and Portugal. They ensured a konkrete Ordnung with the acts of land taking and land distributing that was a founding principle for organizing the political communities and justifying the positivity of the law $($ Recht $) .{ }^{41}$ As it is well known the pope gave the new lands to the Castilian sovereigns in order to spread the word of Christ and exposed the indigenous population to the Catholic religion. In this way he attributed a heavy moral obligation to Ferdinando and Isabella and established a legal title that legitimized the Spanish presence in America in front of the natives as well as the other European powers.

With another Bull he defined the spatial limits of the Spanish dominion. A line traced one hundred miles west from the Azores and running from the North Pole to the South Pole distinguished two different areas. One was reserved for the expansion of the Spaniards; the other could be occupied by the Portuguese, and, at the same time (by opposing to the space of the respublica christiana) demarcated the West Indies as an empty and non-qualified spatial and territorial entity.

Europe needed that empty space for its own existence. "La civiltà europea - Carlo Galli wrote - esiste solo perché è in grado di impossessarsi del nuovo mondo, di occuparlo, di spartirlo, e di confinare là - nello spazio del non Stato - l'inimicizia assoluta, la limitazione della guerra nell'Europa degli Stati, che si riconoscono l'un l'altro come hostes aequaliter justi; è resa possibile dalle guerre illimitate condotte contro i nativi in America (ma anche in Asia e in Africa) e anche fra le potenze europee tra di loro, fuori dal continente europeo." ${ }^{\mathbf{2}}$ But the rajas of Alexander VI were not enough for the definition of a new Nomos of the world. Marked on the Ocean, they ignored its alterity. They had only a simply distributive function and, presupposing the Pope's superior authority, still affirmed the unity of the respublica christiana.

41 Sснмitт (1950a) 81 ff. (it. ed. 1991); see also Sснмitт (1953).

42 Galli (2010) 877-889. 
The emergence of a new order needed, on the contrary, a real revolution with respect to the ordering of territorial spaces. It imposed the overcoming of that unity. According to Schmitt it was possible only when England, "l'isola che si fece pesce," entered the debate thanks to a new "religione guerriera": Calvinism. ${ }^{43}$ The amity lines between England and France that appeared for the first time in a secret clause of the Cateau Cambresis treaty, produced the definitive disappearance of a world and defined the structure of European international law. They ratified the existence of two opposite spaces: one, the European land, realm of law and peace; the other, the Ocean and the still unknown American territories. They were free from law and far from the international treaties, and appeared as real and permanent war theaters in which Western colonial impulses could be vented. Beyond the amity lines the possibilities became endless; there was no more peace and the agreements between European powers had no validity. ${ }^{44}$

Four hundred years later the dissolution of the ius publicum europeum and the deep crisis of the political subjects on whom it was based, ordered the search for a new Nomos. The perspective, nonetheless, remained a spatial one. In a conference entitled La unidad del mundo, held in Spain in 1951, Schmitt expressed his desire to bring about a "tercera fuerza, India, Europe, the British Commonwealth, the Hispanic World, the Arabian System or one more force that had not yet been defined. It could break the "worrying dualism" - between East and West, communism and capitalism, enabling the opening of new macro-spatial perspectives and with them making it possible to single out a principle for their balance and the definition of a new international law. ${ }^{45}$ It was a new law but with a clear analogy with the 19th and 20th centuries' law of nations. In fact also this one "se basaba en un equilibrio de potencias, gracias al cual se conservaba su estructura. Tambien el ius publicum europaeum implicaba una unidad del mundo. Era una unidad Europeocéntrica, no era el poder político centralista de un único dueño de este mundo, sino una formación pluralista y un equilibrio de varias fuerzas." ${ }^{46}$ Nevertheless, to reform the unity of the world, a new

43 Schmitt (1954) (it. ed. 2002, 85).

44 A synthesis of the historiographical debate in: CAssi (2004) 102-114; a critical analysis of the conquest as a production of a new social space in Nuzzo (2004) 87 ff.; Ruschi (20042005) $407 \mathrm{ff}$.

45 Sснмітт (1950-1951), it. ed. 347.

46 Sснмітт (1950-1951), it. ed. 348. 
Christian philosophy of history was also necessary. As a new katechon it could overcome the dualism between the Marxist philosophy of history and the weak historical relativism of the capitalistic West based on progress and technique. Thus it could offer, through an "irrupción concreta de lo eterno en el tiempo," a firm answer to the advancement of dialectic materialism. ${ }^{47}$

Franco's Spain was the geographical space from which it was possible to start the reconstruction of the European identity and the achievement of these aims. Everything began in Spain and in Spain everything could have a new beginning. The Spanish conquest of a New World and the doctrine of Francisco de Vitoria had brought the scientific and cultural foundation of a new law of nations, producing the first change of the structure of international law. ${ }^{48}$ After the end of the Second World War (within a confused and divided Europe) the nationalistic and ultra-conservative Spain seemed to Schmitt the last bulwark. "È una coincidenza significativa - Schmitt wrote in a conference held in 1962 at the Instituto de estudios politicos of Madrid on the occasion of his appointment as a honorary member - che lo slancio sincero della ricerca mi abbia sempre condotto verso la Spagna. Vedo in quest'incontro quasi provvidenziale una prova in più del fatto che la guerra di liberazione nazionale in Spagna rappresenta una pietra di paragone. Nella lotta mondiale che si combatte oggi essa è stata la prima nazione a vincere con la propria forza e in maniera tale che ora tutte le nazioni non comuniste devono legittimarsi davanti alla Spagna sotto questo aspetto." ${ }^{49}$

Spain repaid Schmitt's interest. ${ }^{50}$ At the end of the Twenties Schmitt received his first invitation to hold a conference in Spain and his texts started to be translated. Franco's seizure of power ten years later and the necessity for a stronger theoretical legitimation of the regime made Schmitt a constant presence within the political and legal Spanish debate. ${ }^{51}$

47 Sснмiтt (1950-1951), it. ed. 354; see also Schmitt (1950b) ed. by G. Agamben.

48 Sснмiтt (1943) (ed. it.).

49 Sснмiтt (1962) 218-219.

50 In addition to the friendly relations with Álvaro d'Ors, Herrero (2004), the relationship between Schmitt and Spanish intellectuals are testified by Bесchi (1998) 185, n. 14. The marriage of his daughter Anima with Alfonso Varela Otero, a legal historian who taught at the University of Santiago de Compostela, strengthened Schmitt's bond with Spain, see Mehring (2009) 509-510.

51 The conference was held in 1929 at the Centro de Intercambio Intelectual Germano-Hispano, Madrid and was devoted to Donoso Cortes. 
The historiography reconstructed the relationship between Schmitt and Spain and underlined the reception and uses of Schmitt's legal theory in the Iberian Peninsula. ${ }^{52}$

Recently Ignacio de la Rasilla del Moral, reconstructing the "zero years of the Spanish international law," showed the effect of Schmitt's article, El concepto de imperio en el derecho international, published in the first volume of the Revista de estudios politicos, on the representation of a new Franchist Order and underlined how an "endogamous line of continuity" ran through the German jurist, connecting the intellectual as Legaz Lecambra and Francisco Conde with the international lawyers of the post war years. ${ }^{53}$

In these subsequent pages I will not mention the relevance of Schmitt in the cultural debate of Franco's Spain. I will, instead, attempt to highlight evidence of omissions.

As a matter of fact he was never cited by García Gallo or by the historians of derecho indiano, even though in Spain Schmitt was a highly demanded lecturer, his texts were translated in Castilian, his reflections on the history of the ius publicum europaeum assumed the Spanish conquest as starting point, Vitoria was one of his protagonists, a legal historian, Otero Varela, was his son in law and Álvaro d'Ors, the most important Spanish professor of Roman law, had friendly relations with him. ${ }^{54}$

Why? I will put forward two assumptions and leave the reader to choose the one he or she might like best.

The omission could be either the spontaneous fruit of the shabby nationalism of the legal historians of Franco's Spain that were not really interested in what was happening outside the borders of their country and their discipline, or the consequence of their scientific limitation of understanding the theoretical force of Schmitt's construction. Otherwise this omission could be the consequence of a historiographic strategy that was targeted at the anti-formalist approach of Schmitt or it could be the consequence of his interpretation of Vitoria free from the common universalistic stereotypes.

52 See especially Beyneto (1983); López García (1996).

53 Rasilla del Moral (2012). I would like to thank Ignacio de la Rasilla del Moral for sending me his article.

54 It is interesting to underline the absence of any references to Schmitt in the work of García Gallo (1957-1958) 467-476 on Alexander's Bulls that is opened with a bibliographical recognition. 
It could also be due to the refusal to recognize in the conquest or in the violence of the Landnabme the qualifying factor of the Spanish presence in the West Indies or the starting point of the international law's constitutive process. ${ }^{55}$

\section{Claiming an Identity: Víctor Tau Anzoátegui and the New Horizons of the derecho indiano}

During the 1970s the legal historiography started to become aware of the need for a deep methodological renewal under the pressure of the social and economic transformations that were sweeping through Europe. In addition, the more sensitive Spanish jurists took part to this debate. ${ }^{56}$ In 1977 the Peset brothers and two years later Bartolomé Calvero harshly criticized the methodology of García Gallo and revisited the image that Hinojosa's school had imposed.

They came back to highlight the historical dimension of the law, underlining its relationship with social reality and economic structure, locating the most relevant reasons for Spanish historiographic backwardness and indifference towards a European historical phenomenon as ius commune and the constitutional history of 19th century Spain in the nationalistic glorification of the Hispanic diversity. ${ }^{57}$ And while García Gallo still in 1979 held fast to his dogmatic approach and ascribed the little attention given by Spanish jurists to ius commune to the importance of the German component of Spanish law in the early Middle Ages, Francisco Tomás y Valiente took the last step toward overcoming García Gallo's method. ${ }^{58}$ He closed a revisionist process he started in 1976 in an article with the same

55 Der Nomos der Erde was translated into Spanish only in 1979, but the guidelines of the book already appear from the conferences and the article translated into Spanish that I have quoted in these pages.

56 Scholz (1980).

57 Peset José Luis y Mariano (1977); Peset (1978); Clavero (1979). The first signs of the Spanish methodological renewal are already in Clavero (1974). The same Sevillan Review Historia, Instituciones, Documentos directed by Martínez Gijón was one of textual space where the new themes and the treatment of methodological problems could be afforded freedom within the pages of the Anuario that was not possible in Madrid at the time. Almost twenty years later Petit (1993b) 407 defined it as "último recurso al alcance de disidentes".

58 García Gallo (1980). But see also García Gallo (1986) and (1988). 
title as the famous conference García Gallo held in Rome. ${ }^{59}$ According to Tomás y Valiente the article affirmed that it was no longer possible to conceive legal history as García Gallo did in 1952, but also that "la dirección hacia la que García Gallo había orientado teóricamente la Historia del derecho en España, vista sobre todo desde la triple perspectiva del Manual, de sus propios fundamentos y de la caracterización global del Anuario, no parecía convincente." ${ }^{60}$

When Spain joined the European Community in 1986, Helmut Coing presented at the I Simposio Internacional del Instituto de Derecho Común a paper meaningfully entitled España y Europa, un pasado jurídico común. He recognized the end of Spanish diversity and the belongings of the Spanish culture to European history. The director of the most important European institute of legal history, the Max Planck Institute in Frankfurt am Main, enabled Spain to gain access to the shared memory of the old ius commune, and affirmed the role played by the 16th century Spanish theologians in the process of the transformation of law as a legal science. ${ }^{61}$ Unquestionably, the history recited by the director of Max Planck was nothing more than "the old translatio studii with a few superficial patches to cover its nakedness, a few sops to the peddlers of unstable legal currency." ${ }^{62}$ That is an umpteenth version of the myth of the history of European law: it was conceived in Italy, developed in France, improved in Holland and apexed at the Pandectistic school in Germany. Coing, nevertheless, introduced for his Spanish public an important variant: he certified the existence of the ius commune in the juridical Spanish inheritance, legitimizing the work carried out by the Iberian legal historians, and admitted the champions of the Second Scholastic in the European legal history.

Three years later, in 1989, in a conference organized by the Centro di studi per la storia del pensiero giuridico moderno, Spanish historiography was ready to go on stage, and submitted itself to a kind of 'group psychotherapy' in front of the Italian colleagues. ${ }^{63}$ In the introductory paper Tomás y Valiente

59 Tomás y Valiente (1976a); see also Tomás y Valiente (1976b).

60 Tomás y Valiente (1981) 3640.

61 CoIng (1986).

62 OsLer (1997).

63 Clavero/Grossi / Tomás y Valiente (1990) 633-654, see the review by Serrano GonzáLEZ (1990). 
definitively denyed the representation of the escuela de Hinojosa offered by him. Tomás y Valiente disclosed the ideological manipulation of García Gallo and challenge the very existence of a school of Hinojosa and later of García Gallo. ${ }^{64}$ This was not the only thing. The organizers were conscious that a conference on Hispania had to investigate the legal projection of its image on the overseas dominions. Thus they entrusted Víctor Tau Anzoátegui with the task of explaining the exoticism of the derecho indiano and its relationships with the ius commune and the Castilian law. And Tau Anzoátegui (not forgetting the paper presented by Coing in Murcia, first quotation), furthermore claimed that it was impossible to understand and describe the ius commune in Spain "sin tener debidamente en cuenta ese singular fenómeno de expansión jurídica en el espacio Atlántico." 65

Subsequently the derecho indiano and its protagonists as well as Castilian law and its jurists were knocking at the door of European legal history. There were "un único sistema jurídico de raíz europea continental", and "una única unidad de estudio" into which ius commune, Castilian law and derecho indiano merged. García Gallo and his innumerable works kept offering Tau the methodological coordinates and the irreplaceable portrait of a centripetal system. The object of those methodological coordinates and of that system, however, appeared to be much more complex in the paper presented by Tau Anzoátegui than it seemed if one read the texts of García Gallo or those legal historians that in the same years also saw in the West Indies the European systemic relationship between ius commune and iura propria imagined by Calasso for medieval Italy, and used the Christian values of ius commune for reading the Crown's engagement in favor of the natives and for justifying their submission.

Víctor Tau Anzoátegui kept on declaring his debt to García Gallo, but at the same time proudly remembered his affiliation to the school of Ricardo Levene and, following the historiographic tradition inaugurated by Levene and Altamira (that García Gallo had always criticized because of their lack of legal disposition), sought to restore the complexity of the derecho indiano. ${ }^{\mathbf{6 6}}$

64 Tomás y Valiente (1990); Tomás y Valiente (1993-1994); see also Sánchez-Arcilla BerNAL (2003) 7-19, 48-68.

65 Tau Anzoátegui (1990); Martiré (2001) and (2003).

66 The great attention devoted by the Argentinean school towards history had already been testified by Martiré (1969); on Argentinean legal history see Abásolo (2008). 
Within a common history the derecho indiano was a different type of knowledge and its identity could not easily be bridled by the idea of legislative or jurisprudential system. Besides, the system of García Gallo was not an historical reality, but a projection of his positivistic and nationalistic theory. ${ }^{67}$ Tau Anzoátegui recognized the merits of the Spanish professor and underlined his timid approach to the new methodological proposals during the 1980s, but he did not fail to keep distance from him. Some years later, for example, in a methodological work on the prospects of the derecho indiano, he not only recognized that "persiste en la historiografía, en dosis muy altas, la fuerza modeladora de la cultura legalista," but also invited the legal historians to reconstruct the (broken?) relationships between law and the social net and to substitute "a cultura legalista con una cultura jurídica." ${ }^{68}$ Only a juridical culture could have truly enabled the "situar la ley dentro del ordenamiento en su verdadero lugar, según la materia y las épocas, y habría hecho posible una 'lectura inteligente' - que no es ingenua ni maliciosa - de los textos legales, interrogándolos a la luz de una concepción amplia del fenómeno jurídico." ${ }^{69}$ The awareness of this complexity made it possible to devote attention to the other sources of law: customs, doctrine, and jurisprudence. ${ }^{70}$ It was something of a desire that Tau Anzoátegui himself attempted to satisfy with two important books published in 1992. The first, La ley en Hispanoamérica, was in fact devoted to the different sources of the derecho indiano, and the second, meaningfully titled Casuismo y siste$m a$, was a historical investigation on its espiritu. ${ }^{71}$

Moreover, Tau Anzoátegui was searching for the identity of the derecho indiano, but the discovery or the re-discovery of the legal pluralisms to which its research was leaning, was no longer a problem that had to be overcome, nor was it the starting point of an investigation necessarily addressed at focusing a superior unity. The system had not disappeared and hanged dangerously with its German rigor over the unordered world of the Spanish Indies. Similarly, the idealistic tension that sustained his project could have reproduced the dream of a spiritual and legal unity, making it again possible

67 Tau Anzoátegui (1992b) 63.

68 Tau Anzoátegui (1997b) 41.

69 Tau Anzoátegui (1997b) 43.

70 See Tau Anzoátegui (1986) and (1989).

71 Tau Anzoátegui (1992c) and (1992a). 
to tell the old story of a conquest without conquest nor conquered populations in which the radical native alterity could be dissolved without residuals.

Nevertheless, in the theoretical representation of Tau Anzoátegui the system had an element that counter balanced it. Beyond and against the system there was another category of interpretation, the casuismo. It was too an "anachronistic" concept, as Tau Anzátegui himself underlined. It was a word that once again had nothing to do with facts but that rather dealt with interpretations, helping us to enter into a "cultura común refractaria a la idea de sistema." 72 The derecho indiano was an ordenamiento casuista, a pluralistic order that reflected the pluralism of the political world of Spanish Indies and was able to bravely resist attempts to rationalize the system

Setting the "creencia casuistica" against "idea sistematica," Tau Anzoátegui took back the texts to their contexts and brought back the law into the social world, enabling the critics of a idealistic approach to share his "underground" explorations "debajo de la legislación, la jurisprudencia o la actividad judicial."73 "El derecho indiano - Tau Anzoátegui wrote in the epilogue - aparece como un ordenamiento abierto a distintos modos de creación normas legales, costumbres, jurisprudencia de los autores, práctica judicial, ejemplares, equidad, etc. - con ciertos principios rectores y leyes generales, pero con vastos espaciós para disposiciones particulares, privilegios, excepciones y dispensas. La materia, las personas, el tiempo y las circustancias eran atendidas preferentemente en la solución de los casos dentro una sociedad que lucía sus estamentos o estados." 74

At the five hundredth anniversary of the discovery of America (within a solid historiographic tradition and for the readers with fairly conservative tastes) he offered a deeply innovatory lecture on the American world that, I

72 Petit (1993a) 676. "A riesgo de sorprender al mesurado Víctor Tau con formulaciones radicales - Carlos Petit wrote, 669 - situaré Casuismo y sistema en el terreno así acotado de una historíografia de creación que, siendo jurídica, encuentra además implicaciones en la experiencía de derecho presente y aún puede proyectarse hacia el futuro.” This brings Petit to conclude (671): "la formación que acredita Víctor Tau es sólidamente tradicional, mas ya lo sería menor su mismo pensamiento; Casuismo y sistema, a despecho de la nutrita bibliografía que lo acompaña, sería entonces un libro radicalmente (post)moderno.”

73 Petit (1993a) 668.

74 Tau Anzoátegui (1992a) 570. 
like to think, could have caused doubts and perplexities in García Gallo and in his numerous scholars.

In Casuismo y sistema Víctor Tau Anzoátegui did not directly face the problem of the natives. However, the construction of the legal indigenous order as a casuistic order that was open to the diversities and to the necessities of praxis, allowed a more conscious reflection on the role of the indigenous populations in the Hispanic American society and at the same time encouraged reflection on the control strategies used by the jurists to deny native diversity. The legal pluralism did not anticipate postmodern feelings nor did it arrange them in an ordered and constitutional plan for rights and different subjects that were destined to be sacrificed on the altar of legal formalism of modernity. On the contrary, through different means swinging between protection and repression - the application of some old legal status to indigenous, their introduction into Spanish procedural law, the imposition of the Castilian language, forced urbanization and obviously their conversion to the Catholic faith - it had the aim of one day overcoming the diversity of indigenous populations and erasing their memory.

\section{Bibliography}

Abásolo, Ezequiel (2008), Argentinische rechtshistorische Forschung 1989-2004, in: Zeitschrift für Neuere Rechtsgeschichte 30, 242-258

Ajello, Raffaele (2002), Il collasso di Astrea. Ambiguità della storiografia giuridica italiana medievale e moderna, Napoli: Jovene

Becchi, Paolo (1998), El Nachlass schmittiano. El legado de Carl Schmitt en el Archivo estatal de Dusseldorf, in: Revista de estudios politicos 100, 171-191

Beyneto, José Maria (1983), Politische Theologie als politische Theorie. Eine Untersuchung zur Rechts- und Staatstheorie Carl Schmitts und zu ihrer Wirkungsgeschichte in Spanien, Berlin: Duncker \& Humblot

Внавна, Номі K. (1994), The Location of Culture, London: Verso

Calasso, Francesco (1939), Il problema storico del diritto comune, in: Calasso (1951) $77-136$

Calasso, Francesco (1948), Il diritto comune come fatto spirituale, also in: Calasso (1951) 137-180

Calasso, Francesco (1951), Introduzione al diritto comune, Milano: Giuffrè

Calasso, Francesco (1954), Medioevo del diritto, Milano: Giuffrè

Carty, Antony (2001), Carl Schmitt's critique of Liberal International Legal Order between 1933 and 1945, in: Leiden International Journal 14, 25-36 
Cassi, Aldo (2004), Ius commune tra vecchio e nuovo mondo. Mari, terre oro nel diritto della conquista (1492-1680), Milano: Giuffrè

Chakrabarty, Dipesh (2000), Provincializing Europe. Postcolonial Thought and Historical Difference, Princeton: University Press (Italian edition: Provincializzare l'Europa, Roma: Melteni 2004)

Clavero, Bartolomé (1974), La historia del derecho ante la historia social, in: Historia, Instituciones, Documentos 1, 239-262

Clavero, Bartolomé (1979), Historia, ciencia, política del derecho, in: Quaderni Fiorentini 8, 5-58

Clavero, Bartolomé (2004-2005), Europa hoy entre la historia y el derecho o bien entre postcolonial y preconstitucional in: Quaderni Fiorentini 33/34, 509-607

Clavero, Bartolomé (2007), Ignorancia Académica por España (1944) y privación Indígena por América (1831), in: Derecho, Historia y Universidades. Estudios dedicados a Mariano Peset, Valencia: Universidad de Valencia, vol. 1, 413-423

Clavero, Bartolomé, Paolo Grossi, Francisco Tomás y Valiente (1990), Hispania. Entre derechos propios y derechos nacionales, 2 vols, Milano

Сobo, Martinez (1983), Study of the Problem of Discrimination against Indigenous Populations, U. N. Sub-Commission on Prevention of Discrimination and Protection of Minorities, U.N. Doc. E/CN.4/Sub.2/1983/21 Add.1-7

Coing, Helmut (1986), La contribución de las naciones europeas al derecho común, in: Pérez Martín, Antonio, España y Europa, un pasado jurídico común. Actas I Simposio Internacional del Instituto de Derecho Común, Murcia, 45-61

Conte, Emanuele (2009), Diritto comune, Bologna: Il Mulino

Costa, Pietro (1999), "Ius commune," “ius proprium," “interpretatio doctorum": ipotesi per una discussione, in: IgLesia Ferreirós (1999a) 29-42

Craven, Matthew (2008), The Decolonization of International Law. State, Succession and the Law of Treaties, Oxford: University Press

De Giorgi, Raffaele (2004), Rom als Gedächtnis der Evolution, in: Rechtsgeschichte 4, 142-161

D’ors, Álvaro (1977), Sobre historiografía jurídica, in: Anuario de historia del derecho español 47, 799-811

Fanon, Frantz (1971), Fondamenti reciproci della cultura nazionale e delle lotte di liberazione, in: Fanon, Frantz, Opere scelte, edited by G. Pinelli, Torino: Einaudi

Galli, Carlo (2008), Lo sguardo di Giano. Schmitt e l'età globale. Saggi, Bologna: Il Mulino

Galli, Carlo (2010), Genealogia della politica. Carl Schmitt e la crisi del pensiero politico moderno (1996), Bologna: Il Mulino

García Gallo, Alfonso (1941), Nacionalidad y territorialidad del derecho en la época visigoda, in: Anuario de historia del derecho español 13, 168-264

García Gallo, Alfonso (1948), Hinojosa y su obra, in: Hinojosa y Naveros, EdoArdo DE, Obras, vol. 1, Madrid: González, 13-124 
García Gallo, Alfonso (1951). La ley como fuente del derecho en Indias en el siglo XVI; in: García Gallo (1972a) 169-285

García Gallo, Alfonso (1952), Panorama actual de los estudios de historia del derecho indiano, in: García Gallo (1972a) 37-62

García Gallo, Alfonso (1953a), El desarollo de la historiografía jurídica indiana, in: García Gallo (1972a) 11-35

García Gallo, Alfonso (1953b), Historia, Derecho e historia del derecho. Consideraciones en torno a la escuela de Hinojosa, in: Anuario de historia del derecho español 23, 5-36

García Gallo (1955), El derecho común ante el Nuevo Mundo, in: García Gallo (1972a) 147-166

García Gallo, Alfonso (1957-1958), Las bulas de Alejandro VI y el ordenamiento jurídico de la expansión portuguesa y castellana en Africa e Indias, in: Anuario de Historia del derecho español 27/28, 461-827

García Gallo, Alfonso (1967), Problemas metodológicos de la historia del derecho indiano, in: García Gallo (1972a) 63-119

García Gallo, Alfonso (1971), Metodología de la historia del derecho indiano, Santiago del Chile: Editorial jurídica

García Gallo, Alfonso (1972a), Estudios de historia del derecho indiano, Madrid: Instituto nacional de estudios juridícos

García Gallo, Alfonso (1972b), Bases para una programación de la enseñanza de la historia del derecho y en especial de la del derecho indiano, in: García Gallo (1987), 1069-1102

García Gallo, Alfonso (1974), Cuestiones de historiografía jurídica, in: Anuario de historia del derecho español 44, 741-752

García Gallo, Alfonso (1977), La condición juridica del indio, in: García Gallo, Alfonso (1987) 743-756

García Gallo, Alfonso (1980), El derecho local y el común en Cataluña, Valencia, Mallorca, in: Diritto comune e diritti locali nella Storia d'Europa, Milano, 229-249

García Gallo, Alfonso (1986), Notas sobre la dinámica del derecho, in: Liber Amicorum. Profesor Don Ignacio de la Concha, Universidad de Oviedo: Servicio de publicaciones, 247-251

García Gallo, Alfonso (1987), Los origenes españoles de las instituciones americanas, Madrid: Real Academia de Jurisprudencia y Legislación

García Gallo, Alfonso (1988), Historia del derecho y cultura, in: Estudios jurídicos en homenaje al maestro Guillermo Floris Margadant, México, D. F., 155-161

Guha, Ranaijt (2002), History at the Limit of World-History, New York

Herrero, Montserrat (2004), Carl Schmitt und Álvaro d'Ors Briefwechsel, Berlin: Duncker \& Humblot

Hinojosa, Eduardo de (1910), El elemento germánico en el derecho español (edited by Francisco Tomás y Valiente, Madrid: Marcial Pons, 2000) 
Iglesia Ferreirós, Aquilino (ed.) (1999a), El dret comú i Catalunya. Actes del IV Simposi Internacional. Homenatge al professor Josep M. Gay Escoda, Barcelona: Fundació Noguera

Iglesia Ferreirós, Aquilino (1999b), Ius commune: un interrogante y un adiós, in: Iglesia Ferreirós (1999a) 489-508

Iglesia Ferreirós, Aquilino (2000), Calasso hoy. Una experiencia hispana, in: Durand, Bernard, Laurent Mayali (eds.), Excerptiones iuris: studies in honor of André Gouron, Berkeley: The Robbins Collection, 323-352

López García, José Antonio (1996), La presencia de Carl Schmitt en España, in: Revista de estudios politicos 91, 139-168

Losano, Mario G. (2010), La geopolitica del Novecento. Dai Grandi spazi delle dittature alla decolonizzazione, Milano: Bruno Mondadori

Martiré, Eduardo (1969), La historia del derecho, disciplina histórica, in: Revista del Instituto de Historia del derecho 20, 88-103

Martiré, Edoardo (1996), Alfonso García Gallo y el Instituto Internacional de Historia del Derecho Indiano, in: Homenaje al Prof. Alfonso García Gallo, Madrid: Editorial Complutense (online version)

Martiré, Eduardo (2001), El derecho indiano, un Derecho proprio particular, in: Revista de Historia del derecho 29, 331-361

Martiré, Eduardo (2003), Algo más sobre el derecho indiano, in: Anuario de historia del derecho español 73, 231-264

Mazzacane, Aldo (1998), Methode und System in der deutschen Jurisprudenz des 16. Jahrhunderts, in: Schröder, Jan (ed.), Entwicklung der Methodenlehre in Rechtswissenschaft und Philosophie vom 16. bis zum 18. Jahrhundert. Beiträge zu einem interdisziplinären Symposion in Tübingen, 18.-20. April 1996, Stuttgart: Steiner, 127-136

Mehring, Reinhard (2009), Carl Schmitt. Aufstieg und Fall. Eine Biographie, München: Beck

Mezzadra, Sandro (2008), La condizione postcoloniale. Storia e politica nel presente globale, Verona: Ombre Corte

Morales Padrón, Francisco (1979), Teoria y leyes de la conquista, Madrid: Ediciones cultura hispanica del Centro iberoaméricano de cooperacción

Nuzzo, Luigr (2002), Diritto all'identità e Metanarrazioni. Riflessioni in margine ad un progetto ONU, in: Giornale di storia costuzionale 4,2, 9-20

Nuzzo, Luigi (2004), Il linguaggio giuridico della conquista. Strategie di controllo nelle Indie spagnole, Napoli: Jovene

Nuzzo, Luigi (2008), Dall'Italia alle Indie. Un viaggio del diritto comune, in: Rechtsgeschichte 12, 102-124

Nuzzo, Luigi (2011), A Dark Side of the Western Legal Modernity: The Colonial Law and its Subject, in: Zeitschrift für neuere Rechtsgeschichte 33, 205-222

Nuzzo, Luigi (2012), Origini di una scienza. Colonialismo e diritto internazionale nel XIX secolo, Frankfurt am Main: Klostermann

Osler, Douglas J. (1997), The Myth of European Legal History, in: Rechtshistorisches Journal 16, 397-410 
Paradisi, Bruno (1973), Apologia della storia giuridica, Bologna: il Mulino

Paradisi, Bruno (1980), Il problema del diritto comune nella dottrina di Francesco Calasso, in: Il diritto comune e la tradizione giuridica europea, Perugia: Libreria Universitaria Editrice, 169-300

Peset, José Luis y Mariano (1977), Vincent Vives y la historiografía del derecho en España, in: Scholz, Johannes Michael (ed.), Vorstudien zur Rechtshistorik, Frankfurt am Main: Klostermann, 235-243

Peset, Mariano (1978), Prólogo, in: Pérez Martín, Antonio, Johannes Michael Scholz (eds.), Legislación y jurisprudentia en la España de antiguo régimen, Valencia: Publicaciones de la Universidad, VIII-XII

Petit, Carlos (1993a), El caso del derecho indiano, in: Quaderni Fiorentini 22, 665-677

Petit, Carlos (1993b), El segundo testimonio, in: L'insegnamento della storia del diritto medievale moderno. Strumenti, destinatari, prospettive, a cura di Paolo Grossi, Milano: Giuffrè, 401-414

Piano Mortari, Vincenzo (1987), Il pensiero politico dei giuristi del Rinascimento, in: Piano Mortari, Vincenzo (1992), Itinera juris. Studi di storia giuridica di età moderna, Napoli: Jovene, 215-363

Pietschmann, Horst (1980), Staat und staatliche Entwicklung am Beginn der spanischen Kolonization Amerikas, Münster: Aschendorff

Prakash, Gyan (1994), Subaltern Studies as Postcolonial Criticism, in: American Historical Review 99, 1475-1490

Prakash, Gyan (1995), After Colonialism. Imperial Histories and Postcolonial Displacements, Princeton: University Press

Rasilla del Moral, Ignacio de la (2012), The Zero Years of Spanish International Law, 1939-1953, in: Jouannet, Emmanuelle, Iulia Paris (eds.), Les doctrines internationalistes durant les années du communisme réel en Europe, Paris: Societé de législation comparée

Ruschi, Filippo (2004-2005), Leviathan e Behemoth. Modelli egemonici e spazi coloniali in Carl Schmitt, in: Quaderni Fiorentini 33/34,1, 379-462

Sánchez-Arcilla Bernal, José (2003), Jacobus id quod ego. Los caminos de la ciencia jurídica, Madrid: Dykinson

Schmitt, Carl (1940), Der 'status quo' und der Friede (1925), in: Schmitt, Carl, Positionen und Begriffe im Kampf mit Weimar-Genf-Versailles, Hamburg: Hanseatische Verlagsanstalt, 33-42

Schmitt, Carl (1943), Cambio de estructura del derecho internacional, Madrid: Instituto de estudios politicos (it. ed. Cambio di struttura nel diritto internazionale, in: Sснмітт (1994) 271-298)

Schmitt, Carl (1950a), Der Nomos der Erde im Völkerrecht des Jus Publicum Europaeum, Köln: Greven Verlag (it. ed. Milano: Adelphi 1991)

Schmitt, Carl (1950b), Drei Möglichkeiten eines christlichen Geschichtbildes, in: Universitas 8, 927-931 (it. ed. Tre possibilità di una immagine cristiana della storia, in: Carl Schmitt. Un giurista davanti se stesso. Saggi e interviste, ed. Agamben, Giorgio, Vicenza: Neri Pozza, 249-254) 
Schmitt, Carl (1950-1951), La unidad del Mundo, in: Anales de la Universidad de Murcia 9 (ed. it. La unità del mondo, in: Schmitt (1994) 303-321)

Schmitt, Carl (1953), Nehmen/Teilen/Weiden. Ein Versuch, die Grundfragen jeder Sozial- und Wirtschaftsordnung vom Nomos her richtig zu stellen, in: Gemeinschaft und Politik. Zeitschrift für soziale und politische Gestaltung 1,3, 18-27 (it. trans., Le categorie del politico, Bologna: Il Mulino 1972, 295-312)

Schmitt, Carl (1954), Land und Meer. Eine weltgeschichtliche Betrachtung (1942), Stuttgart: Klett-Cotta (ed. it. Milano: Adelphi 2002)

Schmitt, Carl (1962), El orden del mundo después de la segunda guerra mundial, in: Revista de estudios políticos 122, 19-36 (it. ed.: L'ordinamento del mondo dopo la Seconda guerra mondiale, in: Carl Sснмitt. Un giurista daventi a se stesso. Saggi e interviste, ed. Agamben, Giongio, Vicenza: Neri Pozza 2005, 217-247)

Schmitt, Carl (1994), L'unità del mondo e altri saggi, Introduzione e nota bibliografica di Alessandro Campi, Roma: Pellicani

Schmitt, Carl (1995), Staat, Großraum, Nomos. Arbeiten aus den Jahren 1916-1969, edited by Günter Maschke, Berlin: Duncker \& Humblot

Schmitt, Carl (2005), Die Kernfrage des Völkerbundes (1926), in: Schmitt, Carl, Frieden oder Pazifismus? Arbeiten zum Völkerrecht und zur internationalen Politik 1924-1978, ed. by Günter Maschke, Berlin: Duncker \& Humblot, 73-128

Schmöckel, Mathias (1994), Die Großraumtheorie. Ein Beitrag zur Geschichte der Völkerrechtswissenschaft im Dritten Reich, insbesondere der Kriegszeit, Berlin: Duncker \& Humblot

Scholz, Johannes Michael (1980), Zum Forschungsstand der neueren Rechtsgeschichte Spaniens und Portugals, in: Zeitschrift für neueren Rechtsgeschichte 3, 164-187

Serrano González, Antonio (1990), Hispania, despues de entonces, in: Anuario de Historia del derecho español 60, 633-654

TAu Anzoátegui, Víctor (1986), La costumbre jurídica en la America española (siglos XVI-XVIII), in: Revista de Historia del Derecho 14, 355-425

Tau Anzoátegui, Víctor (1989), La doctrina de los autores como fuente del derecho castellano-indiano, in: Revista de Historia del Derecho 17, 351-408

Tau Anzoátegui, Víctor (1990), El derecho indiano en su relación con los derechos castellano y común, in: Clavero/Grossi/Tomás y Valiente (1990), vol. 2, $572-591$

Tau Anzoátegui, Víctor (1992a), Casuismo y sistema. Indagación histórica sobre el espíritu del derecho indiano, Buenos Aires: Instituto de Investigaciones de Historia del Derecho

TAu Anzoátegui, Víctor (1992b), El tejido historico del derecho indiano. Las ideas directivas de Alfonso García Gallo in: Revista de Historia del derecho 21, 9-72

Tau Anzoátegui, Víctor (1992c), La ley en Hispanoamérica, Buenos Aires: Academia Nacional de la Historia 
Tau Anzoátegui, Víctor (1992d), La noción de la ley en America Hispana durante los siglos XVI a XVIII, in: TAu AnzoÁtegui (1992c) 27-65

Tau Anzoátegui, Víctor (1997a), Diálogo sobre derecho indiano entre Altamira y Levene en los años cuarenta in: Anuario de historia del derecho español 57,1, 369-389

Tau Anzoátegui, Víctor (1997b), Nuevos horizontes en el estudio del derecho indiano, Buenos Aires

Tomás y Valiente, Francisco (1976a), Historia del derecho e historia, in: Tomás y VAliente (1997), vol. VI, 3285-3298

Tomás y Valiente, Francisco (1976b), La historiografía jurídica en la Europa continental (1900-1975), [edited in 1978] in: Tomás y Valiente (1997), vol. VI, $3397-3428$

Tomás y Valiente, Francisco (1981), Nuevas orientaciones de la historia del derecho en España (1981), in: Tomás y Valiente (1997), vol. VI, 3633-3650

Tomás y Valiente, Francisco (1990), Escuelas e historiografía en la historia del Derecho español (1960-1985), in: Clavero/Grossi/Tomás Y Valiente (1990), 11-46

Tomás y Valiente, Francisco (1993-1994), Eduardo de Hinojosa y la historia del derecho en España, in: Anuario de Historia del derecho español 63-64, 1065-1088

Tomás y Valiente, Francisco (1997), Obras completas, 6 vols, Madrid: Centro de Estudios Políticos y Constitucionales

Vallejo, Jesus (1998), La escuela de Hinojosa y las cuestiones de Altamira, in: Pinard, G.E., A. Merchan (eds.), Libro Homenaje. In memoriam Carlos Díaz Rementeria, Huelva: Publicaciones de la Universidad, 765-782

Villapalos, Gustavo (1996), Memoria de un maestro, in: Homenaje al profesor García-Gallo, Madrid: Editorial Complutense, 11-16 

Marta Lorente Sariñena

\title{
More than just Vestiges
}

\author{
Notes for the Study of Colonial Law History in Spanish America \\ after $1808^{*}$
}

\section{Introduction}

On 19 March 2007, a Chilean citizen filed an appeal challenging as unconstitutional a Court Regulation issued by the Court of Appeals in and for the city of Santiago in October 1995. The details of the proceedings are irrelevant here; what is noteworthy is that the judgment that put an end to the proceedings has been considered a true historic landmark. Indeed, not only was it the first time that an action against the interference with fundamental rights was admitted before the Constitutional Court, but it was also the first time that the Chilean High Court had declared partly unconstitutional a Court Regulation issued by the courts of justice. ${ }^{1}$

Although this development sparked great interest among specialists and lay people, I am aware that it is unrelated to the topic of this publication; furthermore, readers could wonder: What relevance to the renewal of legal historiography might a topic of debate about American or European constitutional case law have? What relation is there, if any, between the labor of constitutional courts and the history of Spanish colonial law on which this book is focused? Or, lastly, has Víctor Tau ever addressed the study of the concentrated control of constitutionality?

Firstly, in reply to the last question, I must admit that I am not familiar with any work by the Argentine legal historian on the creation of the control of constitutionality, ${ }^{2}$ the multiplication of constitutional courts, ${ }^{3}$ or finally

* DER2014-56291-C3-1-P. I would like to thank Javier Barrientos and Alejandro Agüero for their comments and information, which helped me develop this work.

1 Aldunate (2007).

2 Cruz Villalón (1987).

3 Von Bogdandy/Cruz Villalon/Huber (2007). 
the transformation of the sources within the system caused by the foregoing. ${ }^{4}$ In fact, I could only attest to the opposite. ${ }^{5}$ However, I believe that the judgment rendered by the Chilean High Court is not only of great interest to those who study the ways in which law is created, ${ }^{\mathbf{6}}$ but also intended for the study of legal historians who have avoided contaminating the interpretation of the legal past with legalism and/or statism, in workshops such as those conducted by Víctor Tau. ${ }^{7}$

The foregoing is not the only reason that can be provided to justify the use of the Chilean judgment as a starting point for this paper. I also believe that its analysis may lead to the formulation of proposals aimed at the renewal of legal historiography as regards the study of colonial law. It is well-known that opening up new thematic and methodological horizons has been a constant concern for Víctor Tau; ${ }^{\mathbf{8}}$ yet, I will quote one of his earliest thoughts, from an interview almost twenty years ago:

"I believe that one of the major topics deserving the attention of scholars is what can be called the Law of the Indies at the transitional stage towards the formation of national law systems."

Víctor Tau himself has developed some aspects of his proposal, ${ }^{\mathbf{1 0}}$ but his works will not be analyzed in the following pages; instead, the aim is simply to try to draw attention to some problematic aspects of the study of transitional law. The first aspect is evident: is it appropriate to include the Chilean case within the Law of Transition? It should be borne in mind that answering this question in the affirmative suggests that not even at the time when "national law systems were formed," "was an end put to what historians have called the vestiges or remnants of the Law of the Indies in national laws. ${ }^{\mathbf{1 2}}$ It is not necessary to be a specialized linguist to realize that the preceding terms somehow convey the idea of a residual. Therefore, this work is chiefly aimed at questioning the use of such terms in the study of transitional law

4 Отто (1987).

5 Tau/Matirè (2003).

6 TAU (1992a).

7 TAU (1992b).

8 TAU (1997).

9 Enciso Contreras/ Del Conacyt (1993).

10 TAU (1977b); TAU (2007-2008).

11 TAU (1977a).

12 Guzmán (2010). 
history, which forces me to start from the very beginning, that is, by trying to prove that the Chilean case must be included in the list of well-known vestiges or remnants.

\section{Colonial Remnants in the 21st Century? From Formal Constitution to Material Constitution in the Republic of Chile}

For a legal historian, the following paragraph of the Chilean judgment is worthy of attention:

"This ample reference hampers the accurate definition of the scope of economic powers since, on the one hand, the reference is too vague: 'manner of operation of the courts.' The manner of proceeding in disciplinary matters is, for certain, a manner of operation (...) The absence of further examples impedes defining the scope given by lawmakers to these powers. The narrow regulatory scope intended by the applicant for Court Regulations is not in line with the tradition of the important matters which have been thus regulated since Colonial times, by the Real Audiencia first, and by the Supreme Court later. Therefore, it is necessary to define the scope of this power at the constitutional level." 13 (Emphasis added.)

The Chilean High Court has given constitutional hierarchy to the continuity between the Reales Audiencias of the Indies and the republican courts, in the understanding that the latter must be seen as an institutional reformulation of the former institutions. Nonetheless, by reading the paragraph transcribed, something that may concern legal historians can be inferred, since even if the Court acknowledges that the boundaries delimiting the regulatory scope of Court Regulations issued by Chilean courts are blurry, it immediately goes on to affirm that tradition, rather than the very confusing current norms, must set the boundaries of such regulatory scope. The fact that the scholarly debate sparked by the judgment has been partly expressed in historicist terms is no coincidence. Having set the groundwork, I believe that the Chilean case helps legal historians free themselves from the endemic loneliness inherent in their work, ${ }^{\mathbf{1 4}}$ ensuring them a place in this topical debate.

13 Aldunate (2007) 229.

14 Caroni (2005). 
1. Terminological considerations: domestic power, immemorial practice and, finally, Court Regulations

The Chilean Constitutional Court ruling partly agrees with the academic sector that identifies the regulatory scope of Court Regulations with the power of self-organization of state organs, a power often called domestic. However, it is worth recalling that this term has quite a strong connotation. In fact, any legal historian would stress that domestic power has a historical meaning that greatly hinders its current use. As is widely known, the historical roots of domestic power can be traced back to ancient times. ${ }^{15}$ Nonetheless, this concept managed to survive by integrating and reformulating itself within the culture of ius commune, which dominated Western legal thinking at least until the revolutionary crises. ${ }^{\mathbf{1 6}}$

To simplify, it could be stated that for such a culture, domestic power was not subject to the law, but rather a direct and largely arbitrary power of the father of a family, which based on love, did not exclude violence. ${ }^{17}$ Undoubtedly, the phrase domestic power sheltered for centuries the most obscure sector of the government of men on both sides of the Atlantic. Thus, for instance, in her study on the "populated house" in San Miguel de Tucumán, Romina Zamora highlighted the operability that such corpus of texts on oeconomics - so interesting for the great Austrian historian ${ }^{\mathbf{1 8}}$ - had in the Hispanic world in the late 18th century. The conclusions drawn by Zamora's study and other similar pieces of research show that there was no reduction in the scope of the ancient domestic power of the 19th century. ${ }^{19}$ Accordingly, it cannot be exclusively identified with the power granted to Spanish and American judiciaries, ${ }^{\mathbf{2 0}}$ given that the survival of domestic power within the sphere theoretically pertaining to individual rights was very common throughout the 1800 s. $^{21}$ In short, there is nothing natural, if I may say so, in attributing such power to courts.

15 Brunner (1977).

16 Vallejo (1998).

17 Hespanha (1997).

18 Zamora (2010).

19 Tío Vallejo (2001).

20 Solla (2011).

21 Agüero (2010); Tío Vallejo (2010). 
Another point to consider is the fact that a wide sector of the Chilean academia insists on underlining the regulatory nature of Court Regulations by focusing more on form than on substance, provided it is understood that the latter means quantity and quality of the contents said Court Regulations may govern. This has considerable effects on the control of constitutionality of such provisions. In any case, what must be emphasized is that a sector of academia has contended that such regulations are rooted on immemorial practice. ${ }^{22}$ While it is true that for some people such practice incorporates traditional elements into the Chilean source system impregnating it with irrationality, ${ }^{23}$ it is also true that, beyond this kind of criticism, the mere use of the phrase immemorial practice suggests specific thoughts to legal historians.

Thus, for example, one could wonder: What connection can be established between the word "immemorial" and the ancient constitution? Even though this term has had a prominent place in many legal systems, history offers some representative examples of its usage in the constitutional terrain. As Pocock rightly demonstrated many years ago, it was certainly English constitutionalism that used it more effectively for the purposes of placing common law outside the scope of political power(s). ${ }^{24}$ Later on, American revolutionaries resorted to a similar discursive strategy, which would have tremendous consequences for constitutional history. As expressed by an expert:

"The British who opposed the American version of the constitution were 'looking ahead,' away from the ancient constitution, to government by consent, to a constitution of parliamentary command, in which government was entrusted with arbitrary power and civil rights were grants from the sovereign. The Americans were 'looking backward,' not to government by consent but to government by the rule of law, to a sovereign that did not grant rights but was limited by rights."25

It is true that not many parallelisms can be drawn between the current Chilean constitutional issues and the political conflicts that confronted the English Monarchy with its Parliament during the 17th century. However, it should be recalled that one thing is to protect immemorial possession and

22 Aldunate (2009a).

23 Aldunate (2009b).

24 Рососк (1957).

25 ReID (2005) 52. 
quite another is to transfer that idea to the realm of constitutional powers. It is in this sense that we might point out that insofar as Chilean legal practice does not go back beyond the creation of the Real Audiencia, ${ }^{\mathbf{2 6}}$ the power granted to its successor institutions does not stem from the dark and indefinite mists of time, but rather from the political will of some very determined men. The term "immemorial" is not used in an attempt to protect the rights of individuals; it is only an institutional practice directly linked to a way of understanding the law and its management which comes from a world where the Audiencias of the Indies identified with the source of all jurisdiction, id est, with the King. ${ }^{27}$

Nonetheless, this widely known story about the political uses of the ancient Constitution, coincident with the immemorial practices that were so deeply rooted in the Hispanic world, does not concern the most classical Chilean constitutional scholars at all. Not only do they accept the existence of Court Regulations naturally, they also contend that they make up a body of general and abstract rules generally issued by collegiate courts aimed at imposing measures or giving instructions for the most expeditious and efficient operation of the judiciary. ${ }^{28}$ In short, the new Audiencias into which the republican courts turned have further reinforced their self-government power, extending it beyond that of the Audiencias of the Indies, since the current system of distribution of competencies is based on regulation and on the predominance of a formal Constitution.

There is little doubt that keeping ancient legal terminology contributes to the legitimacy of continuity. However, while the phrase "Court Regulations" currently has high standing in Chile, the same does not occur in other states that once shared Chile's legal tradition. ${ }^{29}$ The Chilean continuity is striking, because it makes it clear that the political gap opened in 1808 did not affect the survival of the legal tradition in the Spanish American territories. ${ }^{30}$ This can be proved with a single piece of information: the Dictionaries published throughout the 1700s in the Peninsula defined the term "Court Regulation"

26 Barrientos (2003).

27 Garriga (2004a).

28 Silva Bascuñán (2005) 156.

29 TAU (1990).

30 AgüEro (unpublished). 
in the old sense. ${ }^{31}$ Nevertheless, the latest edition of the Diccionario de la Lengua Española [Spanish Language Dictionary] published by the Real Academia Española [Royal Spanish Academy] states that the meaning of the term is:

"In ancient Law, a decision taken as a general point by a supreme court or council with the attendance of all of its divisions." ${ }^{32}$

Such ancient law was kept alive in the colonial Spain of the 19th century, but not in the present one, governed by the Constitution of $1978 .{ }^{33}$ Conversely, Chile has undergone a rare metamorphosis that has enabled it to become part of the regulatory typology determined by the Constitution in force. As some Chilean authors have been claiming, there are still many legal mechanisms created at the core of the Law of the Indies that still survive there, besides Court Regulations. This is the case, by way of example, of the ancient 'consultation' process, consisting of the ratification by an upper court of those resolutions deemed too important to be decided just by a lower court, even without a party's request. Although this consultation process was commonplace in times of the Spanish Monarchy, ${ }^{34}$ it does not have any parallel in Comparative Law. ${ }^{35}$ Legal historians cannot be indifferent to this particular terminological continuity; furthermore, I believe that understanding and explaining it is one of their most important duties. Court Regulations, consultations, visits ... These are all words that have survived in some places, but disappeared in others. Their mere existence or inexistence indicates a

31 The term Court Regulation was not included in the well-known Diccionario de Autoridades, but in the following one: http://buscon.rae.es/ntlle/SrvltGUILoginNtlle. Rafael Altamira largely analyzed the term regulation, but said nothing about the expression Court Regulation: Altamira (1987) 26-28 »Autos«.

32 http://buscon.rae.es/draeI/SrvltConsulta?TIPO_BUS=3\&LEMA=auto.

33 Autos acordados de la Real Audiencia de la Isla de Cuba, Habana 1840; Autos acordados de la Audiencia Chancilleria Real Establecida en Santo Domingo y trasladada a Puerto Principe, suprimida por Real Decreto de 21 de Octubre, cumplimentado en 12 de diciembre de 1853, a la letra, en extracto ó solamente mencionados, según su importancia y vigor, recopilados y anotados por Don José Medina Rodríguez, Puerto Príncipe 1854; Colección de Autos acordados de la Real Audiencia Chancillería de Filipinas y de las soberanas y superiores disposiciones que reúnen a la vez el carácter de gobernadores de provincia, I-V, Manila 1861-1866.

34 Barrientos (1990).

35 Carocca (1998) 197. 
departure from a common tradition, ${ }^{36}$ and also highlights the different value of history as a constitutive element of the law in force, which, undoubtedly, concerns both historians and jurists.

I am aware that these assertions are not innovative. Many decades have passed since Paolo Grossi called for collaboration between historians and jurists, ${ }^{37}$ but I firmly believe that there are not many opportunities for this as offered by the analysis of the Chilean case. Indeed, the complex combination of tradition and will, or, if preferred, between Court Regulations and constitutional normativity, has stimulated a very interesting debate on the adequacy or inadequacy of history to a constitutional order based on the recognition of fundamental rights. ${ }^{38}$ While part of the academia insists that the Political Constitution of the Republic of Chile does not include a single article expressly empowering the Supreme Court to issue Court Regulations, another part maintains that such power is the most important manifestation of the traditional economic superintendence entrusted to said Court, which is currently found in Article 82 (amended text of the previous Article 79 of the Constitution). ${ }^{39}$ This latter sector of academia repeatedly resorts to historicist legitimation in order to justify the attribution of an important regulatory power to the judiciary, ${ }^{40}$ regardless of the framework of the wellknown superintendence granted to the Court and understood as a legacy of the ancient Real Audiencia, which, in addition, is also said to be shared by other Supreme Courts. ${ }^{41}$

We should recall that it was not Chilean legal scholars but the Constitutional Court itself that decided that both the Supreme Court and the Courts of Appeals have jurisdiction to issue Court Regulations. ${ }^{42}$ By way of simplification, it could be argued that the Court has empowered courts to continue acting as they did before and after Chilean independence. In the words of another author:

36 E. g.: Autos, acuerdos y decretos de gobierno del Real y Supremo Consejo de las Indias, Madrid 1658.

37 Grossi (1972) 2.

38 Silva (2009); Pfeffer (2010); Usen Vicencio (2010); Vásquez Márquez (2010).

39 Delgado (2010) 802.

40 Aldunate (2009b).

41 ZúÑIGA (1998).

42 Sentencia Rol № 783 (2007): “Si el artículo 93 no 2 de la Carta fundamental otorga a esta Magistratura competencia para revisar la constitucionalidad de estas normas, es evidente que valida esta competencia". 
"What turns out to be inconsistent in the precedents of the Constitutional Court analyzed herein is that the abstract control of constitutionality finally protects the regulatory powers of the high courts of justice, anchored in the independence of this branch of Government, and especially of the Supreme Court, boasting of a decision on legal policy of absolute deference to the Judiciary; although this is hard to reconcile with the Rule of Law, which requires observance of the principle of legality and of the distribution of regulatory power that places legislation at the top of the hierarchy of the sources of Law; this priority is protected by the principle of democracy." 43

For an observer outside the Chilean constitutional debate, the regulatory power granted to the courts conflicts with the concepts of national sovereignty, formal legislation and separation of powers, which are supposed to be fundamental for modern constitutionalism. ${ }^{44}$ This imaginary observer is further taken aback when finding out, in addition, that from the dissolution of the Real Audiencia of Santiago de Chile in 1817 to the present time, Court Regulations issued by Chilean courts have addressed very general and significant issues, such as the formal aspects of judgments, protection or amparo proceedings [summary proceeding for the protection of constitutional rights or guarantees] and the action for compensation for miscarriage of justice. Moreover, several Court Regulations issued by the ancient Real Audiencia of Santiago maintained full force and effect in the Republic of Chile until the early 20th century. ${ }^{45}$ So, notwithstanding the task of jurists is the analysis of whether Court Regulations are constitutional or not, the historical concepts used by the Constitutional Court to legitimize the existence and the scope of Court Regulations raise manifold doubts regarding their compliance with the basic principles of what we have come to understand as the Rule of Law. ${ }^{46}$

This is the point where legal experts should pay attention to legal historians, who face a task full of challenges, especially that of trying to recreate the complex history of Court Regulations in order to understand what they were and what they currently are. In order to undertake this task reasonably, the role played by Court Regulations must be contextualized during the different stages of legal tradition, where casuistry and system coexisted for many years.

ZÚÑIGA (2011) 415.

44 Grimm (2006).

45 Barrientos (2014) Título preliminar.

46 Costa (2002). 
2. Jurisdictionalism v. statism. The Real Audiencia of Santiago, its Court Regulations and, ultimately, the power of custom in the present-day Republic of Chile

The history of the Real Audiencia of Santiago, meticulously narrated by Javier Barrientos, ${ }^{47}$ is not very clear on the intersection between the economic and / or domestic functions of the Real Audiencia relative to superintendence and the issuance of Court Regulations; furthermore, what Barrientos has described is precisely the opposite. Up to its dissolution in 1817 , the Real Audiencia of Santiago felt no limitation whatsoever to issue Court Regulations, and these actually dealt with all kinds of matters. ${ }^{48}$ Later on, the Court of Appeals, which replaced the Real Audiencia in the first constitutional interregnum, did exactly the same. ${ }^{49}$ I refer readers to Javier Barrientos' thorough analysis on this matter, and I will only point out that to determine the regulatory scope mentioned by the Constitutional Court, which attributes it to the traditional operation of the Real Audiencia, a careful reading of all the Court Regulations it issued is required. Nonetheless, challenges remain ahead; as I believe Víctor Tau would say, the Court Regulations issued by Councils and Reales Audiencias responded to these casuistic beliefs that dominated the legal arena until the late 18 th century.

The following question can be posed based on the foregoing: How can we expect to make systemic abstractions today on historic material that completely ignored them at the time? ${ }^{50}$ Once again, projecting current legal categories in an attempt to fill the well-known superintendence attributed to the Supreme Court distorts the history of that government of justice that differed so much from what we now know as statism. ${ }^{51}$ Indeed, it was this kind of government which managed the Indies, ${ }^{52}$ although it did so by

47 Barrientos (2000a).

48 Barrientos (2000b).

49 Barrientos (unpublished).

50 Ventura Beleña (1789). The first volume of this work is a reprint of the second part of Montemayor's Sumarios, while the second volume contains royal orders for New Spain or instructions issued by New Spanish authorities not collected in the Sumarios). For more information on this jurist, see two contributions: BARRIENTOS (2001a) 125-208; (2001b).

51 Clavero (1986); Hespanha (1989).

52 Barrientos (2004). 
repeating old and creating new problems. ${ }^{53} \mathrm{I}$ will not summarize once again the academic controversy related to the term "Modern State, ${ }^{54}$ which has divided legal historians for decades, ${ }^{55}$ but I cannot resist transcribing a paragraph from one of the greatest Chilean historians. ${ }^{56}$ Góngora endeavored to maintain a very particular concept of state, ${ }^{57}$ which was bellicose and Spenglerian at the same time, ${ }^{58}$ but this paragraph contains a rather contradictory message:

"What we call State is, in the Castilian 16th century, the supremacy of jurisdiction and other royalties, concentrated in the King and exercised through bureaucracy, but also capable of delegations and grants of concession, wider or narrower, under the strictest confidence; privileges so wide that they can be legally defended against the King." 59

It is hard to find a better description of what a part of legal historiography qualifies as jurisdictional culture, ${ }^{60}$ a culture that helped design a series of institutional devices that were implemented throughout the Hispanic Monarchy. ${ }^{61}$ Despite the efforts of some authors to disregard the most recent contributions of European legal historiography, ${ }^{\mathbf{6}}$ the idea of dividing the government of justice into functions entrusted to Reales Audiencias was alien to the basic premises of such culture. In this same vein, it is worth mentioning a subtle warning by Víctor Tau:

"This prevailing criterion of the so-called legal business in the sphere of legal decisions also covered government affairs. A writing of 1714, regarding the management of such affairs, stated that in the Consejo de Indias [Council of the Indies], 'it is unusual to find a file or business which, though denominated governmental, does not contain a great deal of civil, canonical or municipal precedents, laws of the Kingdom, laws of the Indies, Ordinances, resolutions, Bulls and special charters of

53 Martiré (2005).

54 Hespanha (1986).

55 Garriga (2004b).

56 Góngora (1981).

57 Bulnes (1982).

58 Góngora Escobedo (1990).

59 Góngora (1951) 301.

60 AgüEro (2007).

61 Garriga (2006b).

62 Malagón (2005). It is evident that this author has not read the major work by MANNORI/ Sordi (2001). A documentary analysis of the issues dealt with by Malagón can be found in BARRIENTOS (1990-1991). 
the Indies, synodal decrees, and decisions in dubio, for consultation with his Majesty or the Holy See ...' (...) We are in the presence of various legal elements - chiefly compiled into laws and authors - which supported and provided grounds for the decisions to be made." ${ }^{63}$

At present, some jurists suggest it does not appear sufficient to invoke economic powers to replace lawmakers in matters reserved to legislation, since this is in breach of the Constitution and results in a null and void act. Certainly, this sector of academia may share solutions with legal historiography, although not necessarily arguments, given that understanding, appreciating and even criticizing the special regulatory power granted to the Chilean courts - which, based on tradition, allows them to issue Court Regulations - requires a very special background that, when trying to contextualize the different historical values of the term Constitution, ${ }^{64}$ will get rid of the categories that had no place in the pre-revolutionary universe. ${ }^{65}$

Those trying to nurture this particular legal historiography, called critical by others, could clarify the following matters. ${ }^{66}$ Firstly, that colonial tradition cannot be blithely invoked given that by reading the collections of Court Regulations one may notice that the Audiencias in the Indies issued a series of provisions, generically termed court regulations, "dealing with internal matters and appropriate operation of the judiciary, but there was also a considerable amount of orders regarding matters generically classified within the concept of 'good government,' and there are no records that the Crown limited this regulatory activity." ${ }^{67}$ Secondly, that such power prevailed during most of the 1800s in Chile under the different Constitutions that enshrined the principle of separation of powers, to the point that the matter was not only addressed in the debates that eventually resulted in the enactment of the Court Organization and Powers Act of 1875 , but it was also done incidentally by resorting to a generic tradition to (re)found continuity. Such continuity was strengthened with the adoption of the Codes of Civil and Criminal Procedure of 1902 and 1906, respectively. A further step was taken in 1971 with the enactment of a law ordering that a subsection be

63 TAU (1992a) 509.

64 Hespanha (2000) 5-18.

65 TAU (1997).

66 Hespanha (1984); Hespanha (2005) 33-35.

67 Barrientos (unpublished) 37. 
included into Section 96 of the Organic Code of Chilean Courts, which stated that "all court regulations of a general application and nature issued by the Supreme Court shall be published in the Official Gazette." ${ }^{68}$ And, lastly, that even when the Chilean Constitutional Court has exercised control over Court Regulations, it has in turn given constitutional value to a preconstitutional regulatory power.

It is possible to attempt to integrate this special example of colonial survival, if it can be defined as such, within the Chilean legal order; as is widely known, judges and jurists have displayed and continue to display great imagination. ${ }^{69}$ However, it could be said that such power either purports to have a certain originary nature or, as I believe Víctor Tau would say, it forces us to acknowledge the strength of the power of custom in Chile in the 21st century. ${ }^{70}$ At this point, the spirit of Andrés Bello holding his famous Code appears before historians, who, rather surprised, can only wonder: What has happened with the strong assertion according to which "following the example of almost all modern Codes, custom has been deprived of the force of law"? ?1

To sum up, since the existence of Court Regulations has gained ratification in constitutional precedents, ${ }^{72}$ it can certainly be stated that if some aspects of the ancient constitution remain, ${ }^{73}$ the only possible conclusion is the following: the long-standing struggle between formal Constitution and material Constitution still continues in the Republic of Chile in the 21st century. $^{74}$

\section{From Court Regulations to legal historiography}

The question that accordingly follows is: When and how were the foundations of such a confrontation laid in the Hispanic universe? And, more

68 All this information in BARRIENTOS (2014) 2-3.

69 WeINSTEIN (1971).

70 TAU (2001).

71 Message from the Executive to Congress proposing the adoption of the Civil Code, Santiago, 22 November 1855, in: Código Civil de Chile (1961) 28.

72 Aldunate (2009a).

73 Moraga (2007).

74 BrunNer (1983). 
specifically, what relationship can be established between the possible answers to the preceding question and the formulation of proposals to open up the horizons of colonial legal historiography? My aim is to answer both questions briefly henceforth; but since it is not possible to encompass the study of these matters, I will stick to the study of certain issues. Neither of them is unknown to historiography but, in my opinion, they require a modern approach in two senses. On the one hand, I refer to the relationship between fundamental laws and the Constitution after the disaster of 1808 and, on the other hand, to the origins of the hurdles faced by the codification process both in Spain and in different states in the Americas. Both are key issues for comprehending the origin and nature of the persistence of a material understanding of Constitution in the ancient territories of the Monarchy once the revolutionary/independence movements covered the American space with written Constitutions. Without the history of this persistence, I firmly believe that it is not possible to understand the current controversy on the control of constitutionality of Court Regulations in the Republic of Chile.

\section{The Starting Point: from Fundamental Laws to Hispanic Constitutions. ${ }^{75}$}

It is widely known that we owe Ricardo Levene the first delimitation of the Law of the Indies' history, regardless of the fact that his proposals were not accepted peacefully. ${ }^{76}$ Even though I will not attempt to study the history of legal historiography here, I will, in fact, deal with one of its more relevant subject matters: the laws of the Indies. Víctor Tau has warned us against reading them with a legalist view; ${ }^{77}$ he has recently offered a careful description of the condition of the legal order of the Indies before the crisis of 1808:

"That order was not confined to the laws issued by the Court. It had to be extracted from the varied present reality and from the roots of the past. For such purpose, it was necessary to resort to briefings, to critical and historical writings, to the most significant legal instruments, to a varied and changing legislation of both royal and

75 This title belongs to a collective work that has been awarded the Bicentenario de las Cortes de Cádiz Prize promoted by Congress of Deputies: Lorente / Portillo (2012).

76 TAU (2006) 357-417.

77 TAU (2007). 
local laws that, to a great extent, remained outside the scope of the Recopilación [Compilation], and to the experience described by viceroys in their memoirs, etc. This is the foundation of the Collection, to which he (Benito de la Mata Linares) added the results of his work, his professional experience, throughout his years in the magistracy." 78

One of the most relevant features of this legal order was uncertainty, which was part of its own physiology then. However, throughout the final decades of the 18th century, it began to be perceived as a true pathology. ${ }^{79}$ In the words of one of its most fierce critics:

"Royal laws that expressly abolish civil law maxims are commented and twisted so as to reconcile them with the ius commune to which they should conform, as if they did not include any new decision. Gómez and the others, on the basis of the axiom that the abolishment of laws is terrible and must be avoided even against the voices and provisions of law, in order to reconcile them, under the assumption that Roman laws are the genuine ones, will use any fiction or extravagant meaning to render our laws futile." ${ }^{\mathbf{8 0}}$

It should be noted that criticism had scarce incidence in the forum practice, which was marked by unmanageable and unstoppable partitioning. ${ }^{\mathbf{1}}$ Despite some data which could prove otherwise - Nueva Planta Decrees, the decline of Councils and the surge of Secretarios del Despacho (Dispatch Secretaries), the creation of the Intendencias of the Indies, etc. - we must not be misled by appearances. Far from adopting a rationale tending to unify the Law, the Monarchy increased the number of corporations in the last decades of the 1700s, which entailed the multiplication of jurisdictional spheres and their conflicts. ${ }^{82}$ In short, uncertainty reached unprecedented levels, so that many called for a legal reform, which, expressed in political terms, could well be translated into a constitutional reform.

After the crisis of 1808 , however, some dared to suggest that the ancient American constitution was rooted in the laws of the Indies. ${ }^{83}$ It was Fray Servando Teresa de Mier who wrote this proposal that has attracted the attention of historians, ${ }^{\mathbf{8 4}}$ some of whom are convinced that this clergyman

78 TAU (2011) 163.

79 Martínez Marina (1965).

80 Mora y Jaraba (1748) 218.

81 Scholz (1981).

82 Martínez (2007) 11-96.

83 Mier (1990).

84 Góngora (2003). 
was the last criollo $^{85}$ But beyond the political weight of Fray Servando's proposal, what remains true is that it was not shared by the most prominent political personalities of his time, which suggests that the traditional criollo discourse had fallen into decline. ${ }^{86}$ I have used some thoughts of Teresa de Mier with the intention of presenting a well-known issue from an American standpoint, an issue that could be formulated as follows: Did the Catholic Monarchy have a Constitution? And, if so, which one was it? ${ }^{87}$

\section{The Monarchy and its constitution(s)}

To the present day, historians agree that the question about the constitution was not the cause but the consequence of the crisis of the Monarchy. ${ }^{\mathbf{8 8}}$ This approach has further reinforced the long-dated thesis put forth by Halperín Donghi, which states that the events at the time rather than the willingness of Spanish Americans led to independence in Spanish America. ${ }^{\mathbf{8 9}}$ Indeed, it could be summarized that not only independencies, but also Hispanic constitutionalism itself, may be considered the legitimate offspring of the fall of the Catholic Monarchy. I must clarify that by Hispanic constitutionalism I mean the array of texts that appeared in all the territories of the old Monarchy since 1811. In short, I believe that despite the endeavors of the advocates of history understood as the history of progress - if there are any left at this stage - the truth is that rather than the French invasion, it was the shameful resignations of Bayonne and the Constitution granted/adopted there, ${ }^{90}$ that took the then subjects of the Monarchy to wonder whether it had a Constitution. ${ }^{91}$

The mere existence of this question inspired others of greater complexity. With the exception of afrancesados (Francophiles), by 1808 everyone recognized Ferdinand VII as the legitimate Monarch irrespective of the fact that some began to ask a thorny, long-standing question: How many constitutions were there in the Hispanic territories? The history of the Monarchy

85 Annino (2008).

86 Brading (1991); Garriga (2003); Garriga (2006a).

87 Portillo (1998).

88 Portillo (2008).

89 Donghi (1985). A similar approach in Rodriguez O. (2008); Portillo (2006).

90 Busaall (2011); Busaall (2009).

91 Tomás y Valiente (1995); Coronas (1995). 
offered very useful elements to answer this question, given that the Catholic Monarchy was identified with a Republic of Republics, where many of them had a "corporative" constitution. This is exactly what the Marquis of Bajamar expressed in 1785 before the members of the Consejo de Indias he chaired:

"We live (...) in a Christian Republic (...) The Ecclesiastical Hierarchy, Prelates, Dignitaries, Town Councils, Priests for Souls, Religions, Monasteries, Prelacies and Communities have been established. They all live in our House: the Sovereign is its owner, and as such sets forth disciplinary and external governance rules in all matters leading to harmony (...).92

The resignations of Bayonne gave rise to an endless discussion on how to substitute vacatio regis. The volatilization of the physical body of the Monarch was lethal to the ancient corporeal metaphor that had dominated western political theory for centuries; however, many discursive possibilities remained. ${ }^{93}$ The King's escape did not dissolve the traditional corporative structure of Hispanic society(ies) as if by magic, ${ }^{94}$ so that although the Catholic Monarchy had been a Christian Republic, other corporations understood they could claim a similar condition. The miniaturization of the Republic/Monarchy and its embodiment in other republican entities, understood as perfect societies, could not shock anyone given that this notion was one of the chief pillars of the official political culture at the time. As the extremely conservative public law expert Dou y Bassols, who would later sign the Constitution of Cádiz, stated as late as in 1800:

"What cannot be left unnoticed is that it is not detrimental for the absolutely monarchical constitution of a State to contain democratic and aristocratic entities, regarding the powers of the members of such entities, as long as the head of the nation is entrusted to the superiority and sovereignty of the King above all."95

It was in this cultural context that the beloved subjects of the Catholic King were faced with the famous question on whether there was a Constitution or not. Just as it had happened a couple of years before in the French kingdom, this type of questioning signaled that a profound shift in the legal-political paradigm could break with many centuries of history. ${ }^{\mathbf{9 6}}$ If the existence of a

92 Bajamar (1785).

93 Primo de Verdad y Ramos (1808).

94 Lempérère (2004); RoJas (2007).

95 Dou y de Bassols (1974).

96 Furet/HaLÉvi (1996). 
historical constitution was not accepted, then efforts should be made to draft one or more new constitutions, which threatened to create a new constitutional cycle. As widely known, both in the U.S. and in France, the Constitution was no longer considered the result of history: "A constitution is not the act of government, but of a people constituting a government, and a government without a constitution is power without right," said Thomas Paine (The Rights of Man (1791-92) in his famous debate with Edmund Burke (Reflections on the Revolution in France, 1790).

Something similar took place in the Hispanic world. At first, various Peninsular and American public law experts tried to make convincing arguments on the existence of countless historical constitutions, whose revitalization was identified with the recovery of private liberties that had been quashed by centuries of despotism. ${ }^{97}$ Nevertheless, the different territories of the Monarchy underwent a relentless process of drafting written constitutions. Readers interested in Hispanic legal plurality may imagine that the examples of the Kingdom of Navarra or the Basque provinces must have played an important role in the constitutional construct of the time, ${ }^{\mathbf{9 8}}$ which is only partly true because the constitutional diversity that emerged after 1808 was not limited to the well-known forak speeches. ${ }^{99}$ Valencian, Catalan, Majorcan, Aragonese people ... took advantage of what historians have called the "orphanhood of the Hispanic kingdoms" to claim lost liberties, ${ }^{\mathbf{1 0 0}}$ as rightly stressed by the ultraconservative Borrull in a paper published in 1810, that is, almost one hundred years after the Kingdom of Valencia had suffered the enforcement of its Nueva Planta Decree, which abolished Valencian law. ${ }^{101}$

The historical constitutional framework that began to be shaped in 1808 was not exclusively peninsular; in fact, the Spanish perspective prevented contextualizing the interpretation of a key time for the entire Hispanic world. The study of the famous Consulta al País [Country Consultation] stands out among hundreds of examples that could be used as grounds for this assertion. The leading scholars who analyzed this particular initiative

97 Peiró (1985).

98 Portillo (1991); Garcia Pérez (2008).

99 Busaall (2005).

100 Hocquellet (2011).

101 Borrull y Vilanova (1810). 
limited its scope to the Peninsula, and failed to consider the American responses to the Consulta al Pais. ${ }^{\mathbf{1 0 2}}$ At the same time, this stance was shared by American historiography, which did not endeavor to study the Spanish American aspect of the Consulta al Pais either. In summary, for decades historiography either concealed or ignored a series of transcendental writings as responses to the Consulta al Pais. ${ }^{\mathbf{1 0 3}}$ Nonetheless, recent research has shown that the referred Spanish American responses were incorporated into the Instructions to the representatives appointed to the Junta Central [Central Board], ${ }^{104}$ where the political impulse resulting from the organization of the first elections held on Spanish American soil was consolidated. ${ }^{105}$ In other words, too many historians have already incorporated a bi-hemispheric perception of the famous Consulta al País into their research. ${ }^{106}$

In any case, the history of the crisis of the Monarchy and its consequences still requires research not only on discursive uses in the ancient constitution, ${ }^{107}$ but also on those questioning its effective essence. ${ }^{108}$ No matter how hard liberal historiography may strive to prove otherwise, ${ }^{109}$ most of the first representatives of the different Hispanic territories - both in the Junta Central and in the Cortes Generales y Extraordinarias - shared a material perception of what a Constitution was or should be. Thus, the ancient Constitution could be broken down into as many constitutions as territories were represented, and actually all provincial constitutions included both privileges accumulated over the years and new claims, mostly Spanish American, now understood as rights. ${ }^{110}$ In fact, there was a novelty, given that these rights were based not only on their ancient privileges and / or customs, but on the geographical and human elements - topography, climate, fauna,

102 Artola (1959); SuÁrez (1982).

103 Among these instructions there is the Memorial de Agravios [Memorial of Grievances] drafted by Camilo Torres. On this matter, readers may refer to the superb documentary collection published by Almarza/ Garnica (2007).

104 Rojas (2005).

105 Demelas-Bohy / Guerra (1993).

106 Rojas (2008); Almarza (2010).

107 Goldman (2007).

108 Clavero (2000b).

109 Piqueras (2010).

110 It is worth recalling that from early times, several petitions for the acknowledgment of the rights of the trans-Atlantic provinces reached the Peninsula, Garrido (1993). 
flora, condition of the inhabitants, etc. - that had been revealed by the scientific explorations made during the last decades of the 1700s. ${ }^{\mathbf{1 1 1}}$

Hence, there are wide territories to be discovered by means of research showing what elements of the ancient constitution survived beyond the new political horizon that opened up after 1808. Although we know that the Hispanic universe set aside the traditional discourse when the written constitutions were drafted, this fact does not shed any light as to how much of the historic constitution remained in force in the framework created by a new (?) constitutionalism in the ancient territories of the Catholic Monarchy. $^{112}$

2. Political historiography, constitutional historiography

It would be presumptuous of me to assert that historiography has not delved into this complex research field. ${ }^{\mathbf{1 1 3}}$ Moreover, as I have mentioned above, the celebration of the different Bicentennials has not only made available to experts a myriad of sources of potentially unmanageable proportions, but it has also contributed to center much of the debate on independence on constitutional matters. ${ }^{\mathbf{1 1 4}}$ Thus, legal historians might become the main players of a debate that does not only affect the knowledge of our past, but also the understanding of our present.

However, I believe the following diagnosis is not an overstatement: although non-legal historiography has experienced great changes in recent decades, this has not been the case of legal historiography. At present, political history holds the predominant place that economic history held for years. Led by recognized authors such as François Xavier Guerra, ${ }^{\mathbf{1 1 5}}$ this new political historiography has adopted two different stances, namely: It either calls for the specialized knowledge of legal historians, ${ }^{\mathbf{1 1 6}}$ or directly competes with it, insofar as it puts forward new values without resorting to arguments stemming from legal history, be it traditional or modern. ${ }^{117}$ Even

111 Pimentel (1998).

112 Bellingeri (1993).

113 Chiaramonte (2010).

114 Gutiérrez (2010); Calderón (2010).

115 GuERra (1992).

116 Annino (2010).

117 Rodriguez O. (2005). 
though the basic sources for the study of the period are of a constitutional nature and, accordingly, chiefly legal, the value of a legal historian's knowledge in the historiographical field is far from guaranteed. The present state of affairs suggests that a wide gap, caused by a special type of deafness, is dividing historians. In my opinion, the main consequence of this situation is that the interpretation of similar sources (minutes of Town Councils or Assemblies, constitutional regulations, documents on elections, court records, and the like) has become endlessly multiplied and increasingly contradictory. ${ }^{118}$

In this state of affairs, I believe it can be stated that if a new horizon for colonial law history exists, it will need to face a three-fold challenge. In the first place, legal historiography must set aside any nationalist conceit. We might not understand the process that started in 1808 in unitary terms, which means peninsular or American. Nor can we affirm that the first manifestations of written constitutionalism were Spanish, Ecuadorian, Colombian or, Argentine, because none of this political entities existed at that time. Accordingly, the origin of national laws (derecho patrio) cannot be rooted in any of these constitutions, irrespective of the fact that the institutions which started drafting these new texts and establishing new political and institutional practices were not those of the peaceful (?) times of the Catholic Monarchy. In the second place, legal historiography must attempt to explain how terms such as law / legislation, government, justice, representation, responsibility, and so on must be interpreted within their context and not in isolation, ultimately deprived of legal background. If not, our comprehension of the past will be irreparably distorted by virtue of the projection of present categories. Curiously, the foregoing is a defect mostly found in the writings of non-jurist historians, who frequently appear to lack sensitivity regarding the localization of continuities/discontinuities in the language of the law. Lastly, legal historiography must undertake the difficult task of defining the foundations of legal modernity. Within this task, however, the existing difficulties do not stem that much from misunderstandings arising in discussions with other historians but from its own core. The plain truth is that many legal historians have accepted, somewhat uncritically, the methodological options advocated by jurist-historians, who usually pretend to make a genealogy of their own knowledge. Admittedly, this state of affairs

118 Álvarez Junco/Luzón (2006). 
has changed considerably in recent times, though not enough so as to maintain that Spanish and American legal historiography have completely rid themselves of the burden of the past, let alone to certify that a new legal history of constitutional modernity has managed to introduce new historiographical conventions beyond the very limited scope of the discipline. ${ }^{\mathbf{1 1 9}}$

This brief outline of the history of historiography is aimed at giving context to a historiographical argument that broke out against the backdrop of the celebration of the Bicentennials. Focused on the conflict between the ancient and the new constitutions, and deeply marked by artificial territorial determinations, the argument was provoked by the existence of two contradictory versions of the history of the Monarchy crisis. While the first version describes the consequences of the crisis as a rupture, the second version attempts to stress that the continuity of ancient institutional devices and understandings reduced considerably the modern components of new political ideas. This serves to answer not only the usual question of how revolutionary the Hispanic revolutions really were, ${ }^{\mathbf{1 2 0}}$ but also another question that concerns legal historians to a large extent, namely: How inclined to statism were those determined to build new worlds? It must be noted that the term "statism" unconsciously refers us to other terms such as "unity", "generality," "territoriality" "hierarchy," etc. In sum, it refers us to all the elements that make up the photographic negative of a society structured in corporative terms and a political power expressed in jurisdictional terms. ${ }^{\mathbf{1 2 1}}$

3. By way of conclusion: an interpretative proposal

At this point, I will outline the key elements of my proposal, but before I do so, I must admit that they have changed throughout the years. At first, I was lured by the most radical discourses, id est, those that understood Hispanic constitutional power or powers as a departure from the ancient discourse of the corporative Monarchy. However, I later understood that the drafting of written constitutions did not imply a transformation as radical as usually contended.

119 LORENTE (2004).

120 Di Meglio (2008).

121 LEMPÉRIÈre (2003). 
In my opinion, the first Hispanic constitutions shared a common element: all of them gave constitutional validity to a panoply of ancient conceptions and old institutional mechanisms. This meant that large segments of the ancient legal order of the Monarchy were given constitutional hierarchy in their Peninsular and Spanish American versions. ${ }^{\mathbf{1 2 2}}$ I do not mean that there was nothing new under the sun; quite the contrary, Hispanic constitutionalism could not better itself in some aspects considered essential for the establishment of a new constitutional order in other regions. Thus, for instance, the new legal devices, purportedly born from the inclusion of the principle of separation of powers in all constitutional writings, did not undergo major practical reforms on either side of the Atlantic. ${ }^{\mathbf{1 2 3}}$ Something similar holds true for the "revolution of voting," 124 since although historiography has highlighted how swiftly the Hispanic world adopted new electoral practices, it has also stressed that accepting the multiplication of electoral ranks ${ }^{125}$ reinforced the corporative nature of the Hispanic institutional fabric. $^{126}$

In a nutshell, if it is assumed that the first Hispanic constitutionalism voluntarily incorporated a series of elements from the ancient state of affairs, the so-called vestiges or remnants can easily be considered components of the new legal orders that gradually developed both in the Peninsula and in the Americas after the fall of the Catholic Monarchy. There is little doubt that the number of such elements was large, although it is worth focusing on one of them in particular because it is closely related with colonial law vestiges, namely: the establishment within the Hispanic sphere of a new notion of law and, consequently, of Code.

\section{From Casuistry to System}

Víctor Tau has often stated that one of the most fruitful fields for the history of the Law of the Indies is the one that emerged after American independence. Because the interpretations on derecho de transición (Law of Transition)

122 Garriga/Lorente (2007); Lorente (2010).

123 Martínez (1999).

124 Ternavasio (2002); Paniagua (2003).

125 Muñoz de Bustillo (1998).

126 AnNino (1995). 
are so numerous, it is impossible to offer a list of relevant works here. ${ }^{127}$ Nonetheless, I believe the approach that both Peninsular and Spanish American legal historiography share in general is not wholly convincing when placing into perspective the complex background of this Law of Transition. Even at the risk of offering unfair criticism, I will outline what I have come to consider insufficiencies. The first one is clearly evident: For decades, the history of 19th-century law has too often been identified with the history of codification; thus, documents such as government directions, private initiatives, drafting of projects, other foreign documents, parliamentary proceedings, comments on new collections, etc. have made up the basic material of the history of Codification, which has also been governed by the binomial legal modernization $=$ Codes. Scholars have agreed that both Peninsular and Spanish American legal scenarios were dominated by slow Codification for many decades, which means that despite political breakup, legal issues remained very similar on both sides of the Atlantic.

So why do I assert that this strategy is insufficient? Simply because rather than interpreting, it merely describes a known fact, which, in turn, can only be appreciated when contrasting it with the example offered by Napoleonic France. However, if we listen to some contemporaries, the problem did not reside in the inability to draft texts but in transforming a political and juridical culture. By way of example:

"Will our laws be observed hereinafter just because we say so? If nothing is missing in our constitution, how come they have been so neglected? (...) What purpose does it serve for the people that the nation established in its general Congresses that the Kings would abide by them, and that they would undertake this as a sacred obligation (...)? Have we unfortunately not always seen them do precisely the opposite?" 128

Flórez Estrada's fears were well-grounded. It was not by chance that the forefathers of the early Hispanic constitutionalism gave constitutional hierarchy to the legacy composed of documents and practices that only prolonged that casuistic manner of determining and managing the legal order beyond the crisis of the Catholic Monarchy. Thus, the early Hispanic constitutionalism did not only favor the reproduction of a crepuscular ius commune, but also supported it so that its domination of the different Spanish

127 Some of them are excellent: González (1988).

128 Flórez Estrada (1810) 5. 
American and Peninsular scenarios continued throughout much of the 1800s. It was at the core of this constitutionalism that the first hurdle appeared for the establishment of general legislation on both sides of the Atlantic. Let's analyze this:

\section{1. "Taking constitutions seriously"}

The foregoing argument only makes sense if the history of codification is assumed to be part of the history of constitutionalism, which, even if it may appear evident at first, has not had a relevant place in Spanish historiography. In my country, it has been possible to study the history of codified texts without aligning it to constitutional history, so that the chronology of the legal history of the 1800s and 1900s has been almost exclusively marked by different codification landmarks. This kind of understanding of our most recent past has practically disappeared at the heart of modern legal historiography, but it still causes severe damage in the work of many jurists interested in fashioning the history of their own disciplinary fields.

I suggest that the history of Codification needs to finally assimilate Tarello's old proposal, which, as widely known, did not distinguish Constitutions from Codes. In historiographical terms, this long-standing proposal entails the permanent eradication of a dichotomy that for decades has been expressed as follows: Given that Constitutions contained vague political statements deprived of legal value, the true law was embodied in the Codes, which, at the same time, abrogated the ancient casuistic culture that had prevailed in the Christian Western world for centuries. I must stress that if these conceptions are maintained, legal historiography is likely to remain in the same place it was, that is, preserving the history of the Constitution as an exclusive field of research for constitutionalists, political scientists and historians of ideas. It is worth mentioning that I have nothing against their work; my criticism is only aimed at the traditional absence of legal historiography in the area denoted by the history of new Constitutions.

Thus, I believe that there is a first link between Codes and Constitutions that cannot be ignored; it simply requires a close reading of Constitutions. This proposal can be explained as follows: Besides analyzing the main statements contained in Constitutions, it is necessary to do the same with their small print. Here is an example to illustrate this idea: Several historians have commented on the famous declaration of the Cadiz Constitution, and have 
identified it with the clearest precedent of the policy for the unification of law: "The Civil, Criminal and Commercial Codes shall be the same for the entire Monarchy, without prejudice to variations that the Courts may introduce under specific circumstances" (Section 258). The truth is that the intention of the Cortes Generales y Extraordinarias (Constituent Assembly) to unify the law is undeniable; nonetheless, historians tend to forget to relate to the first paragraph of the Section with the second one, although it contains a provision pointing out that the delegates to the Constitutional Conventions of Cadiz were aware of the diversity of territories and peoples. ${ }^{129}$ What the Cadiz Constitution defined as "specific circumstances" looks familiar to those who study the history of colonial law, which for centuries tried to adjust to very different circumstances by using a series of specific mechanisms, among which the recognized obey but do not comply stands out.

Anyway, since the vehemence of the Code did not resist any peculiarities, it was necessary to design instruments to enforce it. ${ }^{130}$ Without them, the idea of a Code, rather than the Code itself, resulted in a dead-end idea, or, otherwise, maintained the limitations already in place during the 1700s in the Hispanic world. ${ }^{\mathbf{1 3 1}}$ Being autonomous, such instruments were determined by a familiar premise: the maintenance of the regulatory legacy of the Catholic Monarchy on both sides of the Atlantic. As was the case with the Cadiz Constitution, almost all Hispanic constitutions included two rather contradictory ideas. On the one hand, they committed to renew the regulatory order and, on the other, they deemed that the ancient order should remain in force until those commitments were made effective. Hispanic constitutionalism, which at the outset had been legitimized here and there with the purported recovery of monarchic laws, finally understood that all of them - king, kingdoms, local corporations, various jurisdictions, etc. continued to coexist under the new constitutional order as long as they did not conflict with it. It shall suffice to recall that the insurgent Constitution of Apatzingán had to acknowledge that “(...) as the Sovereignty of the Nation adopts the set of laws that shall replace the ancient laws, these shall remain in full force and effect, except those repealed herein and in other decrees"

129 Clavero (2000a).

130 Caroni (1996).

131 Clavero (1978a); Clavero (1978b): Clavero (1982). 
(Section 211). In other terms, the first Hispanic constitutionalism was one of the causes - if not the first - for the maintenance of the casuistic rationale that for centuries had managed the legal order of the Catholic Monarchy.

\section{The force of casuistry and the difficulties of the system}

On both sides of the Atlantic, formalizing the constitutions of the regulatory legacy of the Catholic Monarchy brought about a series of effects, among which the accumulation of regulations stands out. Thus, it can well be affirmed that the system continued to be threatened by casuistry for decades. It may seem that the accumulation of regulations is a mere technicality just for the use of legal experts; however, repeals directly affected a new way of conceiving political power, which determined the design of instruments needed to exercise it. Once all Hispanic constitutions had adopted the ancient legacy, they must have undoubtedly pondered this question: in the face of so many texts, from different times and contradicting one other, who decided what law was and how was this done?

The combination of two antithetical notions on how to identify legislation opened the door to a series of widely known issues that dominated the legal scenario in the Hispanic world throughout the 1800s. Firstly, the longstanding idea that law was not exclusively legislation passed by the assembly, but also the ancient privileges and, of course, the opinions of jurists remained. ${ }^{132}$ Secondly, the absence of determination of the regulatory order prevented the establishment of a "normative typology" arranged according to a hierarchical order. Given that a law, order, regulation, ordinance... were absolutely interchangeable, the rules adopted by Parliament could not prevail over those issued by the other branches of government, which retained a significant normative power. Thirdly, the absence of determination of the regulatory order ensured a wide margin of activity to anyone considered a "judge", whether legal experts or laymen. In this respect, we should not be surprised by the great difficulties faced by those committed to implementing mechanisms for the defense of law, such as the establishment of the duty of judges to provide grounds for their judgments, or the establishment of appeals to Courts of Cassation. However, both measures had 
been adopted in France in 1790, that is, a year before the National Assembly approved the first French Constitution. ${ }^{\mathbf{1 3 3}}$

The first Hispanic constitutionalism created an overwhelming and indeterminate collection of texts and interpretations thereof that did not only coexist with ancient regulatory bodies, but also determined the relationship between the legislative, executive and judicial branches, since it forced the reformulation of a set of ancient practices. This had dire consequences insofar as it hindered the unification of the law. Many years after the independence movements, Andrés Bello described some of them:

"For this reform to be truly useful, it must be radical. In no other part of the social order we inherited from Spain is the axe so necessary. As regards political reforms, we are not inclined to dismantling everything; but our trial system merits its total removal and substitution for another. Maybe, it would not be an exaggeration to affirm that this system lacks all guarantees embraced by experience to limit arbitrariness and protect the Law. What sometimes makes us wary of their presence is the concern that exists against some of them, even within the respectable class of magistrates and legal experts. For instance, almost no one recognizes the advantages of having judges and courts ground their decisions, a practice in line with the principle of general responsibility that it is the soul of a republic, or, rather, of any government. In a country where the executive branch cannot make a decision, unless pursuant to a law and by invoking it, on the smallest investment of public monies, can a court have the power to adjudicate disputed property that may be worth hundreds of thousands of pesos without stating pursuant to what law or principle the adjudication has been made, or without explaining why one of the titles invoked must prevail over the other? This seems outrageous." ${ }^{134}$

The new law, allegedly consisting only of the rules adopted by legislative bodies or of exceptional rules issued by executive bodies, continued to be interpreted from the standpoint of forensic practices, which understood that their main objective was to establish "concordances" among normative texts to display the justice in the regulations. Blatantly and briefly put: Bártolo may not have been mentioned any longer in the peninsular forum, ${ }^{\mathbf{1 3 5}}$ but the advice of Gómez y Negro - whose Elementos de práctica forense [Elements of Forensic Practice] originally published in 1806, was re-published on several occasions with its corresponding forms ${ }^{\mathbf{1 3 6}}$ - would be adopted. The afore-

133 LORENTE (1989).

134 El Araucano No 197, Santiago, 20 de junio de 1834.

135 Tormo (2001).

136 Gómez y Negro (1838). 
mentioned work advocated what should be deemed law: el arte de la litigación (forensic practice) must be based on the search for the rule within the history of national law. Continuity prevailed in an editorial market almost entirely dominated by the presence of works written mostly before 1808 , which were criticized, corrected, enlarged, or updated by a succession of authors throughout the never-ending 1800 s. ${ }^{137}$ The best example that shows the success of this particular technique is the well-known Libreria de escribanos [Library of Notaries] by Joseph Febrero, published in 1769, which was reused, or rather (re-)ordered, commented, annotated, etc. not only by various Spanish authors, ${ }^{\mathbf{1 3 8}}$ but also by some important Spanish American ones, ${ }^{\mathbf{1 3 9}}$ who for decades replicated the same technique on the other side of the Atlantic. ${ }^{140}$ Laura Beck has stressed that the "curse" against this type of literature uttered by Savigny and developed by the Historical School, also necessary for the process of structuring the canon of history of legal literature, has created a dramatic gap between historiography and its own sources; in fact, this does not allow us to assess the constituent value such literature had for legal thinking in the Hispanic world of the 19th century. ${ }^{141}$ As Beck has asserted, "while kings and queens came and left, ministers and governments fell, Vinnius, Heineccius and Sala remained unmoved from their 19th-century lawyers' offices”. ${ }^{\mathbf{1 4 2}}$ Briefly, it may be stated that the 19th-century legal-political class nurtured a cult for totally hypocritical legality on both sides of the Atlantic.

In the 19th-century newly formed states, both the Code and its culture were ignored, ${ }^{\mathbf{1 4 3}}$ which was meant to reformulate and assimilate a new conception of the principle of legality, taking steps for its implementation. ${ }^{144}$ The inexistence of the foregoing enabled the literature of the wellknown concordancias (concordances) between Roman Law and the new Spanish, Mexican or Chilean Laws to continue determining the mindset of jurists and informing the practice of judges and courts. This failed to

137 Torres Campos (1897).

138 Reseña crítica (1852).

139 Pascua (1834-1835).

140 González (1998).

141 Beck Varela (2008).

142 Beck Varela (2008) 193.

143 Petit (1995); Petit (1996).

144 LoRente (2001). 
contribute to expedite the emergence of a new concept of general law that threatened to depart, once and for all, from the ancient casuistic culture of ius commune.

\section{Conclusions}

What is the value of history? There are few professional historians who have not asked themselves this question during their life. As is widely known, the answers cover the shelves of well-stocked libraries, so readers need not fear that I expand on this matter. However, I would like to recall some thoughts of Tomás y Valiente, who once asserted: "legal historians play a significant role: to contribute their legal experience of the past for the understanding and improvement of our present world." ${ }^{145}$ Tomás y Valiente, as many others, was concerned with the relation between historical times, ${ }^{\mathbf{1 4 6}}$ but he simplified the matter by affirming that if history has a purpose, such purpose is to understand the present ("anyone who does not make this use of history will write dead books"). ${ }^{\mathbf{1 4 7}}$

To this day, I am not quite certain whether some of the objectives of legal history in general, or of colonial law history in particular, are similar to those in the works of Francisco Tomás y Valiente. My intention has been to follow his advice in this contribution as a tribute to Víctor Tau, in an attempt to relate current issues with the historiographical treatment of what can be considered their origins. In my opinion, the former comes not only from a tradition that started at the time of the Conquest, which served to extend the imprint of European legal culture in the Americas, but from the inclusion of many old notions in the new (?) legal systems following the independencies. Nonetheless, the treatment of this issue may eventually end as the content of dead books if it is not related to a further question I consider essential: Why did the Hispanic world offer so much resistance to the state-building process that dominated the Western world throughout the 19th century? I am aware that before answering this question, its own hypothetical nature may be challenged. Yet, I believe that the Chilean debate over the legitimation of the existence and scope of Court Regulations issued by courts can only be

145 Tomás y Valiente (1997b) 4773.

146 Koselleck (1993).

147 Tomás y Valiente (1997c) 5062. 
explained if we accept that the weakness of general legislation was a key feature of the Spanish and American nations.

This weakness might be verified through the analysis of 19th-century legal practices, which were really old. The creation of laws remained encased in ancient formalities; petitions or claims against the unfairness of ancient laws that once paralyzed their enforcement in the entire Hispanic sphere continued to be in force and proved to be effective as well. At the same time, courts, as well as civil and military administrators, continued to enjoy freedom to determine what should be used in court or executed in each case. A crucial question must be added to the foregoing: Against this backdrop, where the impossible assimilation of a formal concept of law prevailed, who was actually in charge of executing the law? It is in this regard that another exception becomes evident: Hispanic constitutionalism preferred to create corporate, non-hierarchical institutions. In brief, individualism had no room in Spanish-American legal culture.

The adventure that began in 1808 with the separation of powers ended almost where it had begun, since general legislation continued to face similar obstacles for many decades both in Spain and in the different American nations. At this stage, several questions may be posed: When was an end put not so much to the vestiges of the legal order of the Monarchy but to its structuring nature of the new 19th-century orders in both hemispheres? Was there enough room within the new legal orders for outstanding metamorphoses, as was the case of the renowned Mexican amparo? Finally, I am convinced that the comparative study of Transition Law is a real challenge for legal historiography. It may well be included in the list of appealing issues for the development of New Horizons for the study of Colonial Law, which, inter alia, may explain the causes for the high standing that Court Regulations still enjoy in the Republic of Chile. 


\section{Bibliography}

Agüero, Alejandro (2007), Las categorías básicas de la cultura jurisdiccional, in: Lorente, Marta (coord.), De justicia de jueces a justicia de leyes. Hacia la España de 1870, Madrid, 20-58

Agüero, Alejandro (2010), La justicia penal en tiempos de transición. La República de Córdoba, 1785-1850, in: Garriga, Carlos (coord.), Historia y Constitución. Trayectos del constitucionalismo hispano, México, 267-306

Agüero, Alejandro (unpublished), On Justice and "home rule" tradition in the Spanish colonial order. Criminal justice and self-government in Córdoba del Tucumán

Aldunate, Eduardo (2007), Sentencia sobre amparo de derechos fundamentales. (Tribunal Constitucional), in: Revista de Derecho XX/2, 221-238

Aldunate, Eduardo (2009a), La fuerza normativa de la constitución y el sistema de fuentes del derecho, in: Revista de Derecho de la Pontificia Universidad Católica de Valparaíso 32, 443-484

Aldunate, Eduardo (2009b), La distribución de potestades normativas en la Constitución: potestades reglamentarias administrativas, autos acordados y facultades del fiscal nacional, in: Revista de Derecho de la Pontificia Universidad Católica de Valparaíso 33, 371-390

Almarza, Ángel (2010), Las elecciones de 1809 en la provincia de Venezuela para la Junta Central Gubernativa de España e Indias, in: Ortiz, Juan, Ivana Frasquet, (eds.), Jaque a la Corona. La cuestión política en las Independencias Iberoamericanas, Castelló de la Plana, 79-102

Almarza, Ángel, Armando Martínez Garnica (2007), Instrucciones para los Diputados del Nuevo Reino de Granada y Venezuela ante la Junta Central Gubernativa de España y las Indias, online: http://www.banrepcultural.org/ blaavirtual/historia/instrucciones-para-la-junta/index.html

Altamira, Rafael (1987), Diccionario castellano de palabras jurídicas y técnicas tomadas de la Legislación Indiana, México, 26-28

Álvarez Junco, José/Javier Moreno Luzón (coords.) (2006), La constitución de Cádiz: historiografía y conmemoración. Homenaje a Francisco Tomás y Valiente, Madrid

Annino, Antonio (coord.) (1995), Historia de las elecciones en Iberoamérica, Buenos Aires

Annino, Antonio (2008), Imperio, Constitución y diversidad en la América Latina, in: Historia mexicana $58,179-227$

Annino, Antonio (coord.) (2010), La revolución novohispana (1808-1821), México

Artola, Miguel (1959), Los orígenes de la España Contemporánea, Madrid

Bajamar, Marqués de (1785), Discurso exhortatorio pronunciado en el Supremo Consejo de las Indias el día 2 de Enero de 1785, por el Exmo. Sr Marqués de Bajamar, Madrid, MDCCLXXXV (now in Bajamar, Antonio Porlier, Marqués De, Discursos al Consejo de Indias, Madrid 2002, 40) 
Barrientos, Javier (1990), La función consultiva en el derecho indiano, in: Actas de las XX Jornadas Chilenas de Derecho Público, II, Valparaíso, 361-374

Barrientos, Javier (1990-1991), La apelación en materia de Gobierno y su aplicación en la Real Audiencia de Chile (siglos XVII, XVIII, XIX), in: Revista Chilena de Historia del Derecho 16, 343-382

Barrientos, Javier (2000a), La Real Audiencia de Santiago de Chile (1605-1817). La institución y sus hombres, online: http://www.larramendi.es/i18n/catalogo_ imagenes/grupo.cmd?path=1000180

Barrientos, Javier (2000b), El Juzgado de Reos Rematados del Reino de Chile (1781-1805), in: Revista de Estudios Histórico Jurídicos XXII, 117-167

Barrientos, Javier (2001a), Juan Francisco Montemayor de Cuenca (1618-1685). Entre derecho indiano, derecho común y derecho foral, in: Revista de Estudios Histórico Jurídicos 23, 125-208

Barrientos, Javier (2001b), Juan Francisco Montemayor de Cuenca (1618-1685). Un jurista aragonés en las Indias, Zaragoza

Barrientos, Javier (2003), La creación de la Real Audiencia de Santiago de Chile y sus Ministros fundadores. Sobre la formación de familias en la judicatura chilena, in: Revista de Estudios Histórico-Jurídicos 25, 233-338

Barrientos, Javier (2004), El gobierno de las Indias, Madrid

Barrientos, Javier (2014), Código Civil, 3. ed., Santiago de Chile

Barrientos, Javier (unpublished), Introducción a la compilación de los Autos Acordados de la Real Audiencia de Santiago de Chile

Beck Varela, Laura (2008), Vinnius en España. Lecturas católicas de un jurista protestante, Sevilla

Bellingeri, Marco (1993), De una constitución a otra: conflicto de jurisdicciones y dispersión de poderes en Yucatán (1781-1831), in: Annino, Antonio, Raymond Buve (coords.), El liberalismo en México, Münster, Hamburg

Bogdandy, Armin von, Pedro Cruz Villalón, Peter M. Huber (2007), Handbuch Ius Publicum Europaeum, I, Heidelberg

Borrull y Vilanova, Francisco Xavier (1810), Discurso sobre la Constitucion que dio al Reyno de Valencia su invicto conquistador el Señor D. Jayme primero, Valencia

Brading, David A. (1991), Orbe indiano. De la monarquía católica a la república criolla, México

Brunner, Otto (1977), Nuevos caminos de la historia social y constitucional, Buenos Aires

Brunner, Otтo (1983), Terra e potere. Structure pre-statuali e pre-moderne nella storia costituzionale dell'Austria medievale, Varese

Bulnes, María Angélica (1982), El Espacio y el Estado, según el historiador Mario Góngora, in: La Segunda 13.12.82, 4

Busaall, Jean Baptiste (2005), Las instituciones del Reino de Navarra en el debate histórico jurídico de la revolución liberal, Pamplona 
Busaall, Jean Baptiste (2009), Constitution et culture constitutionnelle. La Constitution de Bayonne dans la monarchie espagnole, in: Revista internacional de los estudios vascos 4, 73-96

Busaall, Jean Baptiste (2011), L'espectre du jacobisme, L'expérience constitutionnelle française et le premier libéralisme espagnol (1808-1814), Madrid

Calderón, María Teresa (2010), Clément Thibaud, La Majestad de los Pueblos, Nueva Granada y Venezuela, 1780-1832, Bogotá

Carocca, Alex (1998), La Suprema Corte y sus competencias en Chile. Reflexiones sobre las funciones de la Corte Suprema, in: Ius et Praxis 4/1, 189-220

Caroni, Pio (1996), Lecciones catalanas sobre la historia de la Codificación, Madrid

Caroni, Pio (2005), La solitudine dello storico del diritto, Milano

Chiaramonte, José Carlos (2010), The “Ancient Constitution" after Independence (1808-1852), in: Hispanic American Historical Review 90,3, 455-488

Clavero, Bartolomé (1978a), La disputa del método en las postrimerías de una sociedad: 1789-1808, in: Anuario de Historia del Derecho Español XLVIII, $307-334$

Clavero, Bartolomé (1978b), La idea de Código en la Ilustración jurídica, in: Historia. Instituciones. Documentos 6, 49-88

Clavero, Bartolomé (1982), Leyes de la China. Orígenes y ficciones de una Historia del Derecho Español, in: Anuario de Historia del Derecho Español LII, 193-222

Clavero, Bartolomé (1986), Tantas personas como Estados, Madrid

Clavero, Bartolomé (2000a), Aventuras y desventuras de Napoleón, el Código, por América: Trasplantes ladinos y rechazos indígenas, in: Clavero, Bartolomé, Ama Llunko, Abya Yalal: Constituyencia Indígena y Código Ladino por América, Madrid, 141-233

Clavero, Bartolomé (2000b), Intrigas de Trifón y Anastasio: Apuestas comunitarias vasca y maya entre prototipo constituyente y palimpsesto constituido, in: Clavero, Bartolomé, Ama Llunko, Abya Yalal: Constituyencia Indígena y Código Ladino por América, Madrid, 235-442

Código Civil de Chile, estudio preliminar del Pedro Lira Urquieta, Madrid 1961

Coronas, Santos (1995), Las leyes fundamentales del Antiguo Régimen (Notas sobre la constitución histórica española); in: Anuario de Historia del Derecho Español 65, 127-218

Costa, Pietro, Danilo Zoilo (eds.) (2002), Lo stato di diritto. Storia, teoria, critica, Milano

Cruz Villalón, Pedro (1987), La formación del sistema europeo de constitucionalidad (1818-1939), Madrid

Delgado, Carol (2010), El control de constitucionalidad de los Autos Acordados y los derechos fundamentales, in: Estudios constitucionales, 8/2, 799-812

Demelas-Bohy, Marie-Danielle, François-Xavier Guerra (1993), Un processus révolutionnaire méconnu, l'adoption des formes representatives modernes en Espagne et en Amérique (1808-1810), in: Caravelle. Cahiers du Monde hispanique et luso-brésilien 60, 5-57 
Di Meglio, Gabriel (coord.) (2008), Dossier: Lo revolucionario en las revoluciones de independencia iberoamericana, in: Nuevo Topo. Revista de Historia y pensamiento crítico 5

Donghi, Tulio Halperín (1985), Reforma y disolución de los Imperios ibéricos, 1750-1850, Madrid

Dou y de Bassols, Ramón Lázaro De (1974), Instituciones del derecho público general de España, con noticia del particular de Cataluña y de las principales reglas de gobierno en cualquier estado, I, Barcelona (reproducción facsímil de la edición realizada en Madrid 1800-1813)

Enciso Contreras, José, Becario del Conacyt (1993), Derecho indiano. Entrevista con el Dr. Víctor Tau Anzoátegui, in: Revista Vínculo Jurídico 15, online: http://www.uaz.edu.mx/vinculo/webrvj/rev15-7.htm

Flórez Estrada, Álvaro (1810), Constitución para la Nación Española. Presentada a S. M. la Junta Suprema Guvernativa de España è Indias el 1o. de noviembre de 1809 , Birmingham

Furet, François, Ran Halévi (1996), La monarchie républicaine. La Constitution de 1791, Paris

Garcia Pérez, Rafael (2008), Antes leyes que reyes: cultura jurídica y constitución política en la edad moderna, Navarra, 1512-1808, Milano

GARrido, MARgarita (1993), Reclamos y representaciones. Variaciones sobre la política en el Nuevo Reino de Granada, 1770-1815, Bogotá

Garriga, Carlos (2003), El derecho de prelación: en torno a la construcción jurídica de la identidad criolla, in: González Vale, Luís E. (coord.), XIII Congreso del Instituto Internacional de Historia del Derecho Indiano (San Juan, 21 al 25 de mayo de 2000), II, San Juan de Puerto Rico, 1085-1128

Garriga, Carlos (2004a), Las Audiencias: justicia y gobierno de las Indias, in: Barrios, Feliciano (coord.), El Gobierno de un mundo. Virreinatos y Audiencias en la América Hispánica, Cuenca, 711-791

Garriga, Carlos (2004b), Orden jurídico y poder político en el Antiguo Régimen, in: Istor. Revista de historia internacional 16, 13-44

Garriga, Carlos (2006a), Patrias criollas, plazas militares: sobre la América de Carlos IV, in: Martiré, Eduardo (coord.), La América de Carlos IV, Buenos Aires, $35-130$

Garriga, Carlos (2006b), Sobre el gobierno de la justicia en Indias (siglos XVIXVII), in: Revista de Historia del Derecho 34, 67-160

Garriga, Carlos, Marta Lorente (2007), Cádiz 1812. La Constitución jurisdiccional, Madrid

Goldman, Noemí (2007), El concepto de 'Constitución' en el Río de la Plata (1750-1850), in: Araucaria. Revista Iberoamericana de Filosofía, Política y Humanidades 17, 169-186

Gómez y Negro, Luis (1838), Elementos de práctica forense, 4a.. ed., Valladolid

Góngora, Mario (1951), El Estado en el Derecho Indiano. Época de fundación, 1492-1570, Santiago de Chile 
Góngora, Mario (1981), Ensayo histórico sobre la noción de Estado en Chile en los siglos XIX y XX, Santiago

Góngora, Mario (2003), Pacto de los conquistadores con la Corona y antigua Constitución indiana: dos temas ideológicos de la guerra de la Independencia, in: Góngora, Mario, Historia de las ideas en América española y otros ensayos, Antioquía, 1-28

Góngora Escobedo, Álvaro (1990), El Estado en Mario Góngora, una noción de contenido spengleriano, in: Historia (Santiago) 25, 39-79, online: http:// www.memoriachilena.cl/temas/documento_detalle.asp?id=MC0001391

González, María del Refugio (1988), El derecho civil en México (Apuntes para su estudio), México

González, María del Refugio (1998), La presencia del derecho indiano en México a través de las fuentes legales del Diccionario razonado de Legislación y Jurisprudencia de Escriche, anotadas por Juan N. Rodríguez de San Miguel, in: La supervivencia del derecho español en hispanoamérica durante la época independiente, Mexico, online: http://www.bibliojuridica.org/libros/1/133/13.pdf

Grimm, Dieter (2006), Constitucionalismo y derechos fundamentales, Madrid

Grossi, Paolo (1972), Pagina introduttiva, in: Quaderni Fiorentini 1, 1-4

Guerra, François-Xavier (1992), Modernidad e Independencia. Estudios sobre las revoluciones hispánicas, Madrid

Gutiérrez, Daniel (2010), Un nuevo reino. Geografía política, pactismo y diplomacia durante el interregno en Nueva Granada (1808-1816), Bogotá

Guzmán Brito, Alejandro (2010), El Derecho de las Indias Occidentales y su pervivencia en los Derechos patrios de América. Actas del Decimosexto Congreso del Instituto Internacional de Historia del Derecho Indiano celebrado en Santiago de Chile, desde el 29 de septiembre al 2 de octubre de 2008, Valparaíso

Hespanha, António Manuel (1984), Para uma teoría da história institucional do Antigo Regime, in: Hespanha, António Manuel (comp.), Poder e Instituçoes na Europa do Antigo Regime. Coetanea de textos, Lisboa, 7-89

Hespanha, António Manuel (1986), A historiografía jurídico-institucional e a 'morte do estado', in: Anuario de Filosofía del Derecho 3, 191-227

Hespanha, António Manuel (1989), Vísperas del Leviatán, Madrid

Hespanha, António Manuel (1997), La senda amorosa del derecho. Amor y justicia en el discurso jurídico moderno, in: Petit, Carlos, Pasiones del jurista: amor, memoria, melancolía, imaginación, Madrid, 25-73

Hespanha, Antonio Manuel (2000), Qu'est-ce que la 'Constitution' dans les Monarchies Ibériques de l'Époque Moderne?, in: Themis. Revista de direito I,2, 5-18

Hespanha, António Manuel (2005), A Cultura Jurídica Européia. Síntese de um Milênio, Florianópolis

Hocquellet, Richard (2011), España 1808: unos reinos huérfanos. Un análisis de las juntas patrióticas, in: Hocquellet, Richard, La revolución, la política moderna y el individuo. Miradas sobre el proceso revolucionario en España (1808-1835), Zaragoza, Cádiz, 49-79 
Koselleck, Reinhart (1993), Futuro pasado. Para una semántica de los tiempos históricos, Barcelona

Lempérière, ANNick (2003), De la república corporativa a la nación moderna (1821-1860), in: Annino, Antonio, François-Xavier Guerra (coords.), Inventando la Nación. Iberoamérica, Mexico, 316-346

Lempérière, Annick (2004), Entre Dieu et le Roi, la République. Mexico, XVIeXIXe siècles, Paris

Lorente, Marta (1989), Reflexiones sobre la casación en una época revolucionaria, in: El poder judicial en el Bicentenario de la Revolución francesa, Madrid, 205-219

Lorente, Marta (2001), La voz del Estado. La publicación de las normas (18101812), Madrid

Lorente, Marta (2004), Cultura constitucional e historiografía del constitucionalismo, online: www.istor.cide.edu/istor.html

Lorente, Marta (2010), La Nación y las Españas. Representación y territorio en el constitucionalismo gaditano, Madrid

Lorente, Marta (2011), La doctrina legal y el silenciamiento de los juristas en una España sin Código, in: Quaderni Fiorentini 40, 135-175

Lorente, Marta, José Maria Portillo (dir.) (2012), El momento gaditano. La Constitución en el orbe hispano, 1808-1826, Madrid

Malagón, Miguel (2005), La Historia del control de las Administraciones públicas en la Colonia, online: http://www.usergioarboleda.edu.co/civilizar/LaHistoria DelControlDeLasAdministracionesPblicasEnLaColonia.htm

Mannori, Lucca, Bernardo Sordi (2001), Storia del diritto amministrativo, Roma, Bari

Martínez, Fernando (1999), Entre confianza y responsabilidad. La justicia del primer constitucionalismo español (1810-1823), Madrid

Martínez, Fernando (2007), Estrépito de Tribunales. Competencias de jurisdicción en la España de Carlos IV, in: Martiré, Eduardo (dir.), La América de Carlos IV. Cuadernos de Investigaciones y Documentos, III, 11-96

Martínez Marina, Francisco (1965), Juicio crítico de la Novísima Recopilación, Madrid

Martiré, Eduardo (2005), Las Audiencias y la Administración de Justicia en Indias, Madrid

Mier, Fray Servando Teresa de (1990), Historia de la Revolución de Nueva España de Nueva España antiguamente Anáhuac o Verdadero origen y causas de ella con la relación de sus progresos hasta el presente año de 1813, Paris

Mora y Jaraba, Pablo de (1748), Tratado crítico. Los errores del derecho civil y los abusos de los jurisperitos, Madrid

Moraga, Claudio (2007), Auto Acordados como fuente del Derecho Público. (¿Es la CPR nuestra única y verdadera Constitución?), online: http://www.jornadas derechopublico.ucv.cl/ponencias/Autos\%20acordados\%20como\%20fuente $\% 20$ del\%20Derecho\%20Publico.pdf 
Muñoz De Bustillo, Carmen (1998), Los 'otros' celadores del orden constitucional doceañista: diputaciones provinciales y ayuntamientos constitucionales, in: IÑurritegui, José Mạ, José Mạ Portillo (eds.), Constitución en España. Orígenes y destinos, Madrid, 179-214

Otto, Ignacio de (1987), Derecho Constitucional. Sistema de fuentes, Barcelona

Paniagua, Valentín (2003), Los orígenes del gobierno representativo en el Perú. Las elecciones (1809-1815), Lima

Pascua, Anastasio de la (1834-1835), Febrero mejicano ó sea la Librería de jueces, abogados y escribanos que refundida, ordenada bajo un nuevo método, adicionada con varios tratados y con el título de Febrero Novísimo, dió a luz D. Eugenio Tapia. Nuevamente adicionada con otros diversos tratados, y las disposiciones del Derecho de Indias y del patrio, México

Peiró, Antonio (1985), Las Cortes aragonesas de 1808. Pervivencias forales y revolución popular, Zaragoza

Petit, Carlos (1995), Il 'codice' inexistente. Per una storia concettuale della cultura giuridica nella Spagna del XIX secolo, in: Saperi della borghesia e storia dei concetti fra Otto e Novecento, Bolonia, 179-224

Petit, Carlos (1996), El Código inexistente (ii). Por una arqueología de la Civilística española, in: Anuario de Derecho Civil 49, 1416-1450

Pfeffer, Emilio (2010), Autos acordados, control de constitucionalidad y procedimiento, in: Nogueira Alcalá, Humberto (coord.), Temas de Derecho Procesal Constitucional, Santiago, 65-84

Pimentel, Juan (1998), La física de la Monarquía. Ciencia y política en el pensamiento colonial de Alejandro Malaspina (1754-1810), Madrid

Piqueras, José Antonio (2010), Bicentenarios de libertad. La fragua de la política en España y las Américas, Barcelona

Pocock, John Greville Agard (1957), The Ancient Constitution and the Feudal Law. A Study of English Historical Thought in the Seventeenth Century, Cambridge

Portillo Valdés, José Maria (1991), Monarquía y gobierno provincial. Poder y constitución en las provincias vascas (1760-1808), Madrid

Portillo Valdés, José Maria (1998), ¿Existía una antigua constitución española? El debate sobre el modelo inglés en España, 1808-1812, in: Romano, Andrea (ed.), Il modello costituzionale inglese e la sua recezione nell'area mediterranea tra la fine del 700 e la prima metà dell'800. Atti del seminario internazionale di studi in memoria di Francisco Tomás y Valiente, Milano, 545-585

Portillo Valdés, José Maria (2006), Crisis atlántica. Autonomía e independencia en la crisis de la monarquía española, Madrid

Portillo Valdés, José Maria (2008), Crisis e Independencias. España y su Monarquía, in: Historia mexicana, LVIII,1, 99-134

Primo Verdad y Ramos, Francisco (1808), Memoria postuma del Síndico del Ayuntamiento, Lic. D. Francisco Primo de Verdad y Ramos, en que, fundando el derecho de soberanía del pueblo, justifica los actos de aquel cuerpo (12 de 
Septiembre de 1808), in: García, Genaro (dir.) Documentos históricos mexicanos, II, Nendeln/Liechtenstein, 158

Reid, John Phillip (2005), The Ancient Constitution and the Origins of AngloAmerican Liberty, Illinois

Reseña crítica de las varias ediciones y reformas del Febrero, en Febrero o Librería de jueces, abogados y escribanos comprensiva de los Códigos civil, criminal y administrativo, tanto en la parte teórica como en la práctica, con arreglo a la legislación hoy vigente, por Florencio García Goyena y Joaquín Aguirre, corregida y aumentada por Joaquín Aguirre y J. M. Montalbán, 4a ed. ref. y considerablemente aumentada por D. José de Vicente y Caravantes, I, Madrid 1852, XIII-XVI.

Rodriguez O., Jaime E. (2005), La ciudadanía y la Constitución de Cádiz, Zacatecas Rodriguez O., Jaime E. (2008), La independencia de la América española, Mexico

Rojas, BeATriz (compilación y estudio introductorio) (2005), Juras, poderes e instrucciones. Nueva España y la Capitanía General de Guatemala, 1808-1820, Mexico

Rojas, Beatriz (coord.) (2007), Cuerpo político y pluralidad de derechos. Los privilegios de las corporaciones novohispanas, México

Rojas, Beatriz (2008), Las ciudades hispanas ante la crisis: entre la antigua y nueva Constitución, in: Historia mexicana LVIII,1, 287-324

Scholz, Johannes M. (1981), De camino hacia el templo de la verdad. La crítica de la justicia en el siglo XVIII español, in: Mayans y la Ilustración. Simposio Internacional en el Bicentenario de la muerte de Gregorio Mayans, II Valencia, 573-609

Silva, María Pía (2009), Control de constitucionalidad de los autos acordados, in: Temas actuales de Derecho Constitucional. Libro homenaje al profesor Mario Verdugo Marinkovic, Santiago, 319-333

Silva Bascuñán, Alejandro (2005), Tratado de Derecho Constitucional, VIII, Santiago

Solla, María Julia (2011), La discreta práctica de la disciplina. La construcción de las categorías de la responsabilidad judicial en España (1834-1870), Madrid

Suárez, Federico (1982), El proceso de convocatoria a Cortes (1808-1810), Pamplona

TAu Anzoátegui, Víctor (1977a), La codificación en la Argentina (1810-1870). Mentalidad social e ideas jurídicas, Buenos Aires

TAu Anzoátegui, Víctor (1977b), Las ideas jurídicas en la Argentina (Siglos XIX$\mathrm{XX})$, Buenos Aires

Tau Anzoátegui, Víctor (1990), El derecho indiano en su relación con los derechos castellanos y común, in: Clavero, Bartolomé, Paolo Grossi, Francisco Tomás y Valiente (dir.), Hispania. Entre Derechos propios y Derechos Nacionales, II, Milano, 573-591

TAu Anzoátegui, Víctor (1992a), Casuismo y sistema. Indagación histórica sobre el espíritu del derecho moderno, Buenos Aires 
TAu Anzoátegui, Víctor (1992b), La ley en América hispana, del descubrimiento a la emancipación, Buenos Aires

Tau Anzoátegui, Víctor (1997), Nuevos Horizontes en el Estudio Histórico del Derecho Indiano, Buenos Aires

TAu Anzoátegui, Víctor (2001), El poder de la costumbre: estudios sobre del derecho consuetudinario en América hispana hasta la emancipación, Buenos Aires

Tau Anzoátegui, Víctor (2006), De la sociología al derecho indiano. Contrapuntos entre Ricardo Levene y Ernesto Quesada, in: Revista de Historia del Derecho 34, 357-417

Tau Anzoátegui, Víctor (2007), Cultura jurídica y órdenes normativas en la colonización española en América. Una visión panorámica, in: CAssi, Aldo Andrea, Alberto Sciumé (dir.), Dalla civitas maxima al totus orbis. Diritto comune europeo e ordo iuris globale tra etá moderna e contemporanea, Soveria Manelli (Catanzaro), 117-141

TAu Anzoátegui, Víctor (coord.) (2007-2008), Antología del pensamiento jurídico argentino (1901-1945), 2 vols., Buenos Aires

Tau Anzoátegui, Víctor (2011), El Taller del jurista. Sobre la Colección Documental de Benito de la Mata Linares. Oidor, Regente y Consejero de Indias, Madrid

Tau Anzoátegui, Víctor, Eduardo Martiré (2003), Manual de Historia de las Instituciones Argentinas, Buenos Aires

Ternavasio, Marcela (2002), La revolución del voto. Política y elecciones en Buenos Aires 1810-1852, Buenos Aires

Tío Vallejo, Gabriela (2001), Antiguo Régimen y Liberalismo: Tucumán, 17701830, Tucumán

Tío Vallejo, Gabriela (2010), Papel y grillos, los jueces y el gobierno en Tucumán, 1820-1840, online: http://nuevomundo.revues.org/59266

Tomás y Valiente, Francisco (1995), Génesis de la Constitución de 1812. I. De muchas leyes fundamentales a una sola Constitución, in: Anuario de Historia del Derecho Español LXV, 12-125

Tomás y Valiente, Francisco (1997a), Obras Completas, 6 vols., Madrid

Tomás y Valiente, Francisco (1997b), Laudatio a Paolo Grossi, in: Tomás y VAliente (1997a), vol. 6, 4767-4776

Tomás y Valiente, Francisco (1997c), Pasado y futuro de los partidos políticos. (A propósito del libro de Miguel Artola), in: Tomás y Valiente (1997a), vol. 6, 5062-5072

Tormo, Carlos (2001), El fin del Ius commune: las alegaciones jurídicas en el juicio civil de la primera mitad del XIX, in: Anuario de Historia del Derecho Español LXXI, 473-500

Torres Campos, Manuel (1897), Bibliografía española contemporánea del Derecho y de la política, con tres apéndices relativos a la bibliografía extranjera sobre el derecho español, a la hispano-americana y a la portuguesa brasileña, Madrid

Usen Vicencio, Alejandro (2010), Control de Constitucionalidad de Autos Acordados, in: Jornadas de Derecho Público, Valparaíso, 1-16 
Vallejo, Jesús (1998), Acerca del fruto del árbol de los jueces. Escenarios de la justicia en la cultura del ius commune, in: Anuario de la Facultad de Derecho de la Universidad Autónoma de Madrid 2, 19-46

Ventura Beleña, Eusebio (1789), Recopilacion sumaria de todos los autos acordados de la Real Audiencia y Sala del Crimen de esta Nueva España, y providencias de su Superior Gobierno; de varias Reales Cédulas y Ordenes que despues de publicada la Recopilacion de Indias han podido recogerse asi de las dirigidas á la misma Audiencia ó Gobierno, como de algunas otras que por sus notables decisiones convendrá no ignorar, 2 vols., México

VÁsquez Márquez, José Ignacio (2010), El control de constitucionalidad de los autos acordados dictados por la Corte Suprema, in: Revista de Derecho Público $72,198-210$

Weinstein, Graciela (1971), La naturaleza jurídica del auto acordado, in: Revista de Derecho Procesal 1, 5-34

Zamora, Romina (2010), San Miguel de Tucumán, 1750-1812. La construcción social del espacio físico, de sociabilidad y de poder, online: http://nuevomundo. revues.org/58613

ZúÑiga, Francisco (1998), Corte suprema y sus Competencias. Notas acerca de su potestad normativa (autos acordados), in: Ius et Praxis 4/1, 221-234

ZúÑiga, Francisco (2011), Control de constitucionalidad de Autos Acordados, in: Estudios Constitucionales 9/1, 389-418 

Víctor Tau Anzoátegui

\title{
Provincial and Local Law of the Indies
}

\author{
A research program
}

\section{The Established Point of View and the New Approach}

The historical study of local and provincial derecho indiano examined across a regional situation peripheral to the Spanish monarchy pertains to the disciplinary field of legal history and is socio-legally oriented. It extends to any experience or knowledge related to the legal phenomenon. Therefore, interest lies not only in the normative and doctrinal system, but also in the set of habits of mind and style that encompasses both the actions of legal operators and the expressions found in daily practice due to the action and behavior of different social groups. Socio-legal experiences should be incorporated within the framework of what may be termed local legal culture.

Most legal historiographical studies on the derecho indiano have rested on the assumption that power was established or that law was created at the upper and central levels of a consolidated order. The image of a unitary derecho indiano imposed from the Peninsula, which was perceived to have one general normative power, was accepted by an ample section of the American historiography and spread through cultural spheres. This image met the aspirations of the Enlightenment and, later, those of the liberal political theory of the 19th century, according to which power resided in the State as the central body bringing together other institutions and law was general and uniform. Most historians and jurists read and interpreted ancient texts as well as historical events under this paradigm, and hence reaffirmed that model.

This was the approach that prevailed during most of the 20th century. Historians applied the contemporary state model when studying the past, which implied viewing the law as a normative system created by its exclusive legislative power, evidenced mainly by uniform and complete bodies of law upon which a dogmatic legal system was constructed. From this perspective, 
the derecho indiano was recreated as a legal system established by the central bodies of the monarchy which culminated in the Recopilacion de Leyes de Indias of 1680 [Compilation of the Laws of the Indies], a compilation of the entire body of basic law to be applied in the Americas. Underneath this compiling normative system, a particular, changing and casuistic local or "creole" law was hidden. It was issued by the authorities residing in the Indies by virtue of the power delegated to them by the Metropolis, and it was subject to the mechanism of royal assent.

The most salient academic writings of the mid-20th century traditional legal historiography of the Indies have always reflected awareness that the legal complexity of the Indies was not circumscribed to dogmatic forms. Hence, early experts - Rafael Altamira and Ricardo Levene, and more modern ones Alfonso García Gallo, Ricardo Zorraquín Becú, José M. Mariluz Urquijo and Ismael Sánchez Bella - perceived such interest in studying the local legislation, and even set it as a future research goal, signaling some of the most valuable sources for the task. However, local rules that they identified were regarded as merely supplementary and of lesser relevance.

This view started to change gradually and decisively as the initiative to revise those paradigms was set in motion in the last decades of the century. New historiographical approaches emerged, some placing high value on the political-legal autonomy of the peripheral regions from the central power (Antonio M. Hespanha). Consequently, the centralized and uniform conception of the derecho indiano started to weaken while an image of multiplicity started to gain strength. It stemmed from the diverse geographical and human realities bundled in the Americas, which obviously could not be reflected in a uniform legal body. Cities began to assume a major role in the creation and application of a system of their own (Bartolomé Clavero). On the basis of variety and Spanish American casuistry, it was necessary to attend to the realities and interplay of a multiplicity of jurisdictional and normative powers that contributed to the development of a peculiar and local provincial system.

Thus began to open a new path of theoretical studies and fieldwork, in which local law was neither merely supplementary nor limited to an isolated area of the derecho indiano: rather is has adquired a level of importance undreamt-of before, to the extent that it has come to offer a novel approach to study the whole legal system in force in Spanish American. Furthermore, in this approach this local law is a core element in the continuity of the legal 
culture of the Indies after the emancipation, during the so-called period of derecho patrio or national law of Spanish American countries, until the time of codification.

Aided by the new theories of recent times and the decline of the former political paradigm, other images are emerging nowadays that depict a multiple and boundless derecho indiano born in different places of the New World, respondent to the diverse geographical and human realities bundled in the vast continent, and which make it possible to recognize the existence of diverse local and provincial normative systems.

A new approach (based upon Antonio M. Hespanha's model criterion) posits as a hypothesis the inversion of those terms, addressing the possibility that local areas might be genuine sources of power and creation of law. This inescapably leads to the reconsideration of old assumptions and to the awakening of brand-new ideas about the 'center-periphery' axis and the existence of multiple jurisdictional and normative powers which sometimes work simultaneously at different levels (Tamar Herzog). This encourages the comparison of the mechanisms operating in different local contexts. This operation highlights the structure and dynamics of this vast political entity, as well as the nature of the different laws (socio-legal systems) that were present in it, with diverse margins of autonomous expression and centralized imposition according to time and circumstances.

The local legal phenomenon arises as a new instrument to learn more about the derecho indiano and, in a broader sense, to deeply understand the mechanisms of articulation in that political entity of great territorial dimensions: the Hispanic monarchy of Spain and the Indies during the Modern Age. Despite the considerable historical-political and historical-legal bibliography on the topic, some issues and questions remain unanswered. These are real legal historiographical problems that call for new light to be shed in order to reach a satisfactory and comprehensive understanding of both its structure and historical development throughout the three long centuries of its existence. In this sense, the approach suggested approach here may contribute to a deeper understanding.

The specific framework of this approach is limited to a particular space and time: the provinces of the Río de la Plata, Tucumán and Cuyo from the 16th to the 18th centuries. During this period, the foregoing provinces were viewed as peripheral to the centers of political power - Madrid, Lima and Charcas - until the creation of the Viceroyalty in 1776, when their status was 
put on a par with that of other peripheral regions of higher rank within the monarchy.

The matter will be addressed in key areas or subjects of that local law. This approach will help revise, adjust and modify, if applicable, the conceptual framework. It will also pave the way for future research in other areas, and for a deeper and more comprehensive analysis of the areas considered here, so that local law will progressively achieve scientific consistency.

\section{Research Design. Research Work Areas}

The legal culture of the Indies cannot be conceived as the mere normative reflection of a Spanish America geographically integrated with a monarchy based in Europe, nor can it be identified with passive acceptance of metropolitan directives. On the contrary, it is essential that we understand that derecho indiano was still in force far beyond political emancipation, and that while its structure had general characteristics perceivable across the whole Indies, specific regional and local varieties emerged that were the result of different geographical, social and economic realities. In other words, it has come the time to consider outdated these old historiographical tendencies, under which the study of the derecho indiano was limited to its normative system and questions almost exclusively related to legal creation by an almighty political authority residing in the metropolis. This retrospective view now gives way to the image of a more flexible and multiple derecho indiano, which emerged from a diversity of geographical and human realities. Hence, it is convenient to limit the scope of the research program to a particular geographical area, without precluding its broader placement within the legal culture of the Indies and its focus on comparative history across different regions.

The central premise consists in placing focus on an area which, conceived as a natural formation, served as a setting for the display, on various levels and by a multiplicity of peripheral powers - often difficult to identify - of genuine legal autonomy. Such a situation would be a result of a multilayered combination of mechanisms of action and the simultaneous resistance to royal authority, which was indifferent to being placed within canons derived from rationalistic hierarchical conceptions. Its constant display suggests that those in charge of the administration of provincial and local law, rather than mere recipients of graciously delegated power, acted as real 
guardians of alternative authority. This image undermines the credibility of the classic reductionist views, under which the monarchy would appear as the sole power vested with legitimate authority to make laws.

The areas to be studied in particular must be carefully selected taking into consideration the nature of the topic, its local roots, and the availability of experts in the field recognized for their previous knowledge of the subject, who might allow the conclusions of their research to be integrated to the common project.

In order to advance in the knowledge of this provincial and local law, six key study topics have been set as specific objectives. The goal is to detect elements in them through which local features can be verified and analyzed. These topics are: (1) the political condition in the city and the province; (2) the local normative fabric; (3) jurisdictional culture and justice; (4) family and household order; (5) the concept of property and the exploitation of natural resources; and (6) the relation between the universal and the particular in canon law. Some of these topics are now being examined in a number of research projects, whose findings reveal the value of delving into the material and disseminating the analysis so that new elements shaping the local legal culture begin to emerge.

1. The political condition in the city and the province

The root of the local system lay in the city - city meaning "republic" and "corporation" - with its own entity and exclusive law. Both the urban region and the contiguous rural area were under its jurisdiction. Among the constituents of the population center, houses and families, convents and monasteries, unions and associations, schools, universities and consulates stood out at the lower level, each with their rules and regulations, benefits and exemptions, customs and traditions, chiefs, prelates and governors. When Castillo de Bovadilla stated that "houses are small cities and cities are big houses," he was picturing the basic layers constituting that local system. The political, economic, and judicial authority was vested in the Cabildo and the royal official, which acted as guardians of corporations and people. Their normative activity extended mainly over the public sphere, more or less intensely depending on time and place.

Working from more general layouts of the political condition (R. Zorraquín Becú), texts and testimonies depicting characteristic situations can be 
gathered that may help refine the way the issue is addressed and verify whether or not there is a correspondence with those layouts, and to what an extent they should be modified or nuanced.

Most importantly, this process will go hand in hand with new historiographical approaches that, without ignoring the existence of a strong tendency towards centralization and uniformity during those centuries, regard the Spanish monarchy as a balanced, complex order, whose powers were spread among recognized centers of authority and their peripheries, and where the monarch played a preeminent yet not dominant role. This new view seems to be in better accordance with the analysis of a reality where the vastness, variety, and specificity of its elements, together with the distance that lay between the provinces and the Crown, precluded the everyday exercise of government from the Peninsula.

This new approach leads us to consider different mechanisms of power, from the one present in clientelism and corporatism to that produced by bureaucracy itself, all this intertwined by subtle links that changed depending on the circumstances. It is thus more proper to talk about a horizontal, rather than a vertical, order in the conception of power, and recognize the existence of fields of action reserved to each sphere of power.

This can be verified by the relation between the local authorities in the provinces of the Río de la Plata and Tucumán with the king and the Peninsular bodies. As I have observed while studying the consultations of the Consejo de Indias [Council of the Indies], the Cámara [Chamber of the Indies] and the Junta de Guerra [Board of War] during the 17th century, the matters they addressed revolved around the following: appointment of royal and ecclesiastical officers, concession of grants and graces, treatment and evangelization of native people, leaves of absence for travel, foreign trade control, and defense and fortification of the territory. A strong intervention in judicial affairs can also be observed, when serious cases of violence, abuse or excess of power by magistrates and governors were reported. The practical exercise of authority by the monarch can thus be limited to certain areas and situations, and it becomes selective and eminent. The remaining power is distributed between the Spanish American centers and peripheries (Lima, Charcas, Santiago de Chile for Cuyo, etc.). The city wields considerable normative and jurisdictional power.

A description of what fell under the charge of the Cabildo is recorded in a Buenos Aires council minute of the year 1674, during the course of a power 
dispute. The passage is very suggestive and requires an extensive study, impossible to carry out in this paper for reasons of space. Its first part reads: "Cabildos (...), under their royal laws and ius commune, are vested with the power to rule the city and hear matters pertaining to it, by governing each and every part of it, paying attention to the protection of its fruits and crop fields, its sustenance and that of its people, peacefulness, price, amounts, and better distribution, in such way as they may agree at any time, and deciding whatever they may deem convenient (...)."

New examples and texts can contribute to the treatment of this matter.

\section{The local normative fabric}

When we consider that prior to the nineteenth century there was a world of diverse and autonomous powers - supernatural, natural and human -, in which norms were created in processes carried out at different levels (Hespanha, Cultura Jurídica), it is easier to understand how law was classified in the principal Castilian vocabularies of the early modern age. Two of the seven categories, specifically concerned the local sphere, which thus appeared as a genuine source of power and of law, and not merely as a power delegated by another higher sphere. These two categories were the law ordained by the city or town for its private government and that introduced by custom. However, the different levels of the legal system were implicitly articulated by overarching principles or values according to subject matter, people, and circumstances. Provincial and local law were far from being comprehensive and exclusive. On the contrary, they were open to laws and customs of other places and spheres of power.

It is difficult to define local law because there is no exclusive sector that may actually be so designated. The approach towards a notion of local law should emanate from each city, province or kingdom, analyzing the fabric of the legal system from the bottom up, watching its development and verifying its possibilities to peak or decline. That is to say, a study of this kind is limited to certain geographical areas, and there should be no immediate intention of expanding the results obtained to all the Spanish Indies.

In his research of the city as a general concept, and Seville in particular, between the fourteenth and sixteenth centuries, Bartolomé Clavero notes the absence of what might be termed "a general system" or "communal organization." Nor was there a legislative power that could establish the rules to 
govern the city. What did stand out as an organic whole was the intellectual power of ius commune and moral theology case law, which "laid down principles, formulated guidelines and enabled modulation." It was an effective construction. In addition, there were other normative levels, some closer to what we now understand as law, other levels of a decidedly moral nature, and some that we could classify as socio-legal practices, with separate legal entity and binding. Within this normative fabric lies a customary background that "calls for historiographical creative space." This same universe of multiple norms - laws, customs and practices -, both written and oral, is a topic deserving patient and intelligent research. Seville can be used as a model for a Spanish American city. And indeed, over the centuries under review this model was frequently referred to.

What was the attitude adopted by the central government of the monarchy towards the mass of norms that was continuously being created in the different local spheres of its vast territory? The question is part of a fundamental issue, which is the articulation of the different levels of power and, obviously, the possibility to control the legal production of the peripheries. The Consejo de Indias suffered from an information gap regarding this issue and although there were attempts to fill it, little could be done to make local authorities in the New World send the required information on a permanent basis. Despite the basic interest behind that question, we lack an adequate response today, one with the necessary supporting documents. A working hypothesis could be the following: according to the governing style that can be noted in other matters, and given the material impossibility to control all the corners of its political domains, the Crown consented or surreptitiously permitted, and even approved, local or provincial self-management and the subsequent legislative production in the understanding that kingdoms, provinces and cities enjoyed jurisdictional and regulatory powers that could not be ignored as long local or provincial authorities continued to recognize and maintained their loyalty toward the supreme political authority in the monarch.

This is the issue that deserves the undivided attention of researchers today to grasp the way in which such implementation of law was understood in local life, such implementation being an intertwined fabric of case law/legal knowledge and solutions arising from the local socio-legal experience. 


\section{Jurisdictional culture and justice}

In the research design of a program of this nature, a thematic approach to the issue stated in the title is essential. It is perhaps convenient to attempt such an approach by resorting to a recent work by Alejandro Agüero, in which he sets out the conceptual bases of a study on the topic, whose working hypothesis may be applied to our provinces. By "jurisdictional culture," Agüero means "a form of power organization and management which can be observed with sparse variations in every European political space from the late Middle Ages until the end of the eighteenth century.' Underpinning that concept are the basic assumptions that social order rests on the idea of a divinely created universe beyond the will of humans (transcendent order), and the idea of the supremacy of a community over its individuals that is applied in various associative expressions (corporation). There are other key elements, such as the primacy of religion in the discourse of knowledge, the relationship between words and things, and the validity of a topical reasoning. The legal culture of the time was thus structured on "a discourse of political power exclusively linked to its concept of justice." The legitimate exercise of power was tied to the theological notion of justice that gave everyone what, as of right, belonged to them. In charge of said exercise was an authority that enjoyed iurisdictio, that is, it was vested with some degree of jurisdiction. It followed certain rules of procedure and led to the resolution of the issue, based on procedural rigor and the virtues of the magistrate.

Among the various facets of justice, criminal justice is worth noting. Mario Sbriccoli laid out for the European world of the early modern period a slow transition, entwined by multiple archaistic and modernistic lines, from a "negotiated criminal justice" to a "hegemonic institutional justice," which narrowed the room for negotiation and imposed the idea that no justice could exist without punishment of the guilty. The state started monopolizing punitive power by taking over the duty to apply the punishment rigorously on the basis of four technical presuppositions: the law, the act, the evidence, and the sentence. This model can be used as a working hypothesis to study the world of the Indies in the early modern period.

By way of example, we will refer to Alejandro Agüero's recent work: a study on these forms of criminal justice in Córdoba del Tucumán in the seventeenth and eighteenth centuries. This author points out the difference between the punitive severity of laws and known practice. Agüero finds 
discursive strategies and social practices that helped settle conflicts without resorting to the formal rigor of laws. Clemency, pardon, and complicity by judges and by the parties involved (victims and perpetrators) were procedures that could be seen in practice. This view of criminal justice attempts to overcome a more unilateral view of that past itself, a consequence of the strong mark left by the Enlightenment.

Another issue that can be addressed in this area is the one regarding the imposition that several local texts - particularly manifest in the bands of good government of the late eighteenth century - made on city dwellers: to act as assistants of justice in reporting or detecting different violations of legal and moral norms that were committed in the city and in the countryside.

\section{Family and household order}

In a study that has become a classic, Otto Brunner discussed with unmatched finesse the meaning given in Europe until the eighteenth century to the "big house" ruled by its master, who had power over economic activity and to protect and control all those living in it, including a broad right to punish his people and the domestic service. It was precisely at that time when - he adds - "the absolute State, which had concentrated in its hands the protection of peace and the police, penetrated the house." But thanks to the theory of natural law peace in the house was enshrined as one of the fundamental rights, and only by means of a court order could the power of the state penetrate its sphere.

This is the same concept developed in the Siete Partidas, that "this word family" - it reads - "denotes the master and his wife, and all the other individuals living in the household under his command, as well as the children and servants and the other servants." The father of the family was at the top of the small power pyramid sustaining the house, a situation that can be framed within a pyramidal relation as compared to the prince, the "father" of the territory. Alejandro Agüero states: "Disciplined by religion and guided by the Económica, the power of the father of the family was withdrawn from the rules of jurisdictional discourse to the extent that his function was performed within an organic unity where subjective plurality was as inconceivable as the smallest otherness, required by a balancing game dealing with disparate interests implicit in the notion of justice (...). Instead 
of mediating between various subjective interests, the function of the father of the family was to guardthe interests of his home, 'manage' the assets to ensure the economic viability of the family unit and thus ensure the welfare of its members."

This family scheme prevailing in Europe was transferred to the New World, where it underwent changes and adaptations as required by the new conditions and by the transformations brought about by the diverse processes of colonization which characterized the typical Spanish and Creole family of the Indies. A detail worth mentioning is the relevant role played by women when leading the family on some occasions, as stated by Dougnac, due to the frequent absence of their husbands.

Mario Góngora explains that "in a socio-historical sense, a house comprises a considerable number of inhabitants: the head of the household, his wife, their unmarried sons and daughters, and often their married children with their own spouses and children; other relatives, including children born out-of-wedlock; servants and those 'added' to the household, who also used to have offspring." Góngora concludes that "this is, properly speaking, a family in the traditional sense." The head of the household had a wide and strong authority that allowed him to exercise the government and supreme direction of the house, while women, children and the other members of the domestic community owed obedience and submission. He ruled over the family and enjoyed free administration of assets and corrective powers over his children, etc.

It is possible to learn about the rich and secretive world of the family and the domestic order, as it operated before the nineteenth century, by reading some passages from the bands of good government. Though their provisions are not too explicit, they are always suggestive. They are isolated or minor expressions because the power of the legislature only actually reached the gates of the "big house." It is rare to find such provisions recorded before the last quarter of the 18 th century.

The late appearance of certain precepts regarding the domestic order, resulting from the silence of the previous era, probably serves to prove the condition of the "big house," exempt from any jurisdiction alien to it in everyday life, where the civil authority could not enter.

Texts of a different nature evidence the privileged position enjoyed by the big house or casa de señores. The question arises as to whether these texts are remnants or traces of a previous situation or whether they signal the begin- 
ning of a transformation combining (or rejecting) the intervention of the civil authority and the protection and guarantee of the rights of the individual. Such contradictory combination of ideas or purposes would not be strange at a time as troubled as that of the late 18th and early 19th centuries.

As can be seen from the foregoing, the issue offers different working hypotheses. Researcher Romina Zamora has already conducted significant research into the topic in one of the major cities of the region, San Miguel de Tucumán, in the last decades of the 18th century, which may serve as a starting point to further study or to extend it to other cities. Moreover, to the traditional figure of the "big house" or "noble house" Zamora has added the "plebeian house" whose presence and role is less visible in documents due to the existence of a hierarchical society; perhaps it is mentioned only in passing in some documents, these mentions being derogatory at times, but deeply ingrained through customs and social practices.

5. The concept of property and the common exploitation of natural resources

Whoever embarks on the task of venturing further into local law will unavoidably be faced with this key issue. European scholars of legal history, politics and social history (such as Paolo Grossi, Bartolomé Clavero, José Antonio Maravall and E.P. Thompson) have written clarifying theoretical and empirical articles that receive special treatment in every research paper on the subject.

According to Maravall, "the concept of property underwent a dramatic transformation" during the fifteenth and seventeenth centuries. It evolved "restrictively to mean the free individual disposition of assets," deviating from medieval criteria which imposed a set of connections, prescribed common uses, and ordered assistance to the poor and needy. This preface can only introduce us to a very complex issue full of nuances and contradictions, as may be corroborated by resorting to the suggestive pages in which Paolo Grossi deals with the study of the historical forms of property and the big cultural debate on that matter in the 19th century Europe, or to the ones written by Clavero on the matter in the French Revolution. Both provide food for thought and an opportunity for the exchange of ideas.

The referred pages written by European scholars do not include the distinctive features of this matter in Spanish America so we need to resort to 
local texts. Our aim is to attempt an empirical approach to that complex and sometimes contradictory world, where more than one line or path can be discerned, and where together with a Modern-Age process of innovation, persistent medieval traces can still be detected. They can be found in the wording of local legal texts but mainly in their background. The matter appears repeatedly in almost every place, but there are also specific cases that ought to be singled out.

A point worthy of mention is the one regarding the community of wild woods, quarries, and rivers. General regulations such as those issued in 1514 were coupled with royal decrees addressed to the Río de la Plata in 1696, 1708 and 1711, in which natives and residents of the Indies were granted the common use of pastures, woods and waters, and the residents of the city of Buenos Aires were allowed the enjoyment thereof, and could even cross the river to Colonia del Sacramento, for the exploitation of wood and firewood without limitation (Mariluz Urquijo). This generalized system started to encounter weak or open resistance depending on how advanced the conceptions proclaiming the individual and absolute nature of property - which excluded all forms of collective exploitation - were.

The common exploitation of various natural resources began to be restricted by the eighteenth century, as much to establish their exclusive use by the city residents - and exclude outsiders without a license - as to declare illegal formerly accepted practices or customs of common use, which were now defined as "abuse," " theft" or "robbery". These texts must be read carefully and between the lines. In a chapter of the band of Buenos Aires Governor Bermúdez, of 1715, it is stated: "none be bold to commit wrongs in the city or in the field by taking horses, oxen, cows, fruit or any other thing for, though trivial as it may seem, it will be declared theft as the taking was against the owner's will ...' It seems here that theft was being introduced as a criminal offence to make a sharp distinction between the thing subject to the exclusive will of its owner and what could fall within the scope of an eventual common use in practice or, at least, tolerated common use.

In these blurred boundaries between what can be defined as an object of individual property or common exploitation, it is worth resorting to another text of the band of Santa Fe, written in 1709, in which the deputy governor expressed that "because I am aware of the very serious chaos and lack of fear when it comes to the theft of mules, horses, oxen, cows, calves and other service animals because it is not yet considered a venial crime, and that not even 
indoors can said animals be safe, I hereby order that ..." no person "under any circumstances may take livestock or animals of this kind without the express authorization of their owners ..." The text recognizes, by means of certain idiomatic turns - highlighted in italics -, the existence of a practice or use not typified as a crime that the new rule purports to change, by considering it theft and prescribing an express penalty. This was an attempt to sketch out an order in which the individual property of things was becoming more clearly defined. The idiomatic turn used in the provision to establish the requirement to obtain express authorization from the owner to take a livestock leads us to infer that the person did not have the intent to claim ownership over the livestock, but rather to use it temporarily as something available for common use.

A very clear example can be found in an order issued by the Cabildo of San Luis in 1779, which reads: "All individuals shall refrain from the common practice of stealing branches and firewood from stubbles and fences ... and those burglarizing farms or stealing fruit shall be subject to the same penalty." This is neither the place nor the time to engage in certain digressions, but this order to refrain from a "common practice", which is then treated as stealing and later extended to cover other acts of burglary of farms or theft of fruits, seems suggestive. It gives the impression that we are faced with a text pinpointing, by means of highlighted words, transitional moments between the common exploitation of certain natural elements and a stricter privacy and exclusivity in the use of individual property.

6. The relation between the universal and the particular in canon law

There are few areas of law that have been as significant to the everyday lives of the men and women of the Old Regime as canon law. Its rules governed life and death, accompanying people from baptism to extreme unction. On the periphery of the Empire in particular, the priest was often the only lawyer, and law was taught solely at the seminary. Notwithstanding this great significance to daily life, which historians of various fields have increasingly detected, the norms of canon law applied locally were based on normative corpora dating from the Middle Ages, intended for the faithful as a whole. This relation between the universal conception of these norms, designed to govern the whole Catholic world, and their particular scope of 
application, with the required adaptations and adjustments, makes the study of canon law an enlightening experience for the program described.

Among the various sources that can be studied in this context, so far we have analyzed, firstly, some problems based on the provisions of diocesan synods (Martini, Dellaferrera). Another highly interesting source consists of texts emerging from university teaching that reveal conscious and unconscious adjustments, the use of ius communesources and the changes introduced in an attempt to select and present the required material for jurists in a certain place. Some of the classes taught in courses of canon law at the University of Córdoba del Tucumán are particularly enriching in this context and have been published recently, among them a treatise on impediments to marriage, the fruit of classes taught during the year 1734 (Silvano GA Benito Moya/Guillermo de Santis). This treaty contains disputationes on key aspects of the canonical doctrine of marriage - violence and fear; clandestine marriage; impediment of relationship (cognatio) - and offers the possibility to analyze the abovementioned aspects about the modus operandi of the jurist in the Cordoba of the 18th century, comparing the explanation with other contemporary sources (such as Ius canonicum universum by Reiffenstuel). Furthermore, it allows a comparison between university education and forensic practice.

Thomas Duve has posed questions regarding the local application of derecho canónico indiano, including to what extent the particular experiences of the implementation of norms in the Indies impacted upon the Old World. Thus, he states that "the dialectic between the realization of authority in the transplant of the canon law tradition to the Indies on the one hand, and pluralization within this legal culture might even contribute to discover a true Atlantic dimensionof Legal History, beyond the studies on the unilateral reception of the European legal culture in the Indies."

\section{Research Methodology}

The program falls within the discipline of legal history and, therefore, follows its methodological guidelines, which were amended throughout the 20th century. The long-standing debate over whether this is historical or legal science - often settled with eclectic criteria - has been overcome. The position of the discipline between History and Law generated interest and was scientifically sound when Dogmatics was highly regarded in the legal field, 
and the legal dimension was dismissed by historians. Both situations have changed.

That relation progressively changed as a stronger link between law and society was sought, and broader "methodological freedom" was introduced that sought to incorporate other disciplines - sociology, anthropology, literature, linguistics, theology, political science, etc. - and open up possibilities for the development of interdisciplinary work, while still acknowledging that Legal History has an individuality and a scientific observatory of its own, which offers its findings to other areas of knowledge.

A very noticeable consequence of this change has been an improved articulation between normativity and social reality. To achieve this, it is necessary to move out of the narrow scope in which Dogmatics enclosed the notion of law, ignoring any other normative sphere than that established by the positive law of the State. In Antonio M. Hespanha's words, "The most relevant criticism against traditional Legal History is not so much its formalism as its dogmatism. The former may constitute a positive attitude in that it safeguards legal institutional autonomy and avoids reductive determinism; the latter prevents any historical contextualization, because institutions or doctrinal dogmas are found to be necessary models (and therefore ahistorical) derived from the nature of things or rational evidence. In contrast, the proposed orientation, in relativizing legal institutional models, draws us to consider the study from a historical perspective, placing these models in the context of the history of cultural forms and, consequently, their insertion in practical contexts" (European legal culture).

There is a tendency to set aside the firm conviction that considered of scientific interest to the historian only those matters that the dogmatic legal scholar defined as pertaining to the legal field. From these new standpoints, it is interesting to admit the existence of normative orders outside the one officially recognized and, generally, this helps expand the researcher's horizon.

This also leads to a more frequent use, with true methodological root, of the phrase "legal culture of the Indies" - virtually unknown in the past instead of "Castilian-Indian legislation" (as has hitherto been usual), since it is a deeper and more comprehensive phrase alluding to a phenomenon that cannot be restricted to the legal sphere. It is useful to bear this in mind when analyzing local issues.

Pursuing a research program of this nature, which falls squarely into the specific discipline of Legal History, requires looking into and incorporating 
conceptual tools and documentary and bibliographic material of other scientific disciplines that foster the study of humankind and society.

\section{Recommended Bibliography}

Given the nature of this article, I have omitted the inclusion of a most comprehensive range of scholarly works; instead, this list includes works used in the text and others that may lead to further consideration and information of the matters discussed herein.

Agüero, Alejandro, Espacio local y jurisdicción criminal en el Antiguo Régimen. La justicia penal en Córdoba del Tucumán siglos XVII y XVIII. Tesis doctoral laureada en la Universidad Autónoma de Madrid, 2003, Inédita

Agüero, Alejandro, Las categorías básicas de la cultura jurisdiccional. Capítulo I del libro: De justicia de jueces a justicia de leyes: hacia la España de 1870, Madrid 2006, 21-58

Agüero, Alejandro, Clemencia, perdón y disimulo en la justicia criminal de Antiguo Régimen. Su praxis en Córdoba del Tucumán, siglos XVII y XVIII, en: Revista de Historia del Derecho 32 (2004) 33-81

Agüero, Alejandro, Ley penal y cultura jurisdiccional. A propósito de una Real Cédula sobre armas cortas y su aplicación en Córdoba del Tucumán, segunda mitad del siglo XVIII, en: Revista de Historia del Derecho 35 (2007) 13-45

Agüero, Alejandro, Ciudad y poder político en el antiguo régimen. La tradición castellana, en: Cuadernos de Historia 15 (2005) 237-310

Aspell, Marcela, Los factores de distorsión de los mecanismos del control social de la población rural en la jurisdicción de Córdoba del Tucumán. Asperezas, conflictos, soluciones, en: Revista de Historia de Derecho 30 (2002) 87-147

Benito Moya, Silvano G. A. y Guillermo de Santis, Fabian Hidlago SJ (16971770): Tratado acerca de los impedimentos de Matrimonio. Estudio, transcripción paleográfica y versión española, Centro de Estudios Históricos "Profesor Carlos A. Segreti”, Córdoba 2005

Brunner, Otto, La 'casa grande' y la 'oeconomica' de la vieja Europa, en: iDem, Nuevos caminos de la historia social y constitucional, Buenos Aires 1976, $87-123$

Clavero, Bartolomé, Tantas personas como Estados. Por una antropología política de la historia europea, Madrid 1986

Clavero, Bartolomé, Antidora. Antropología católica de la economía moderna, Milano 1991

Clavero, Bartolomé, Del Estado presente a la familia pasada, en: Quaderni Fiorentini 18 (1989) 583-605 
Clavero, Bartolomé, Les domaines de la propriété 1789-1814: Propiedades y propiedad en el laboratorio revolucionario, en: Quaderni Fiorentini 27 (1998) 269-378

Clavero, Bartolomé, Sevilla, Concejo y Audiencia: invitación a sus Ordenanzas de Justicia, Introducción al volumen Ordenanzas de la Real Audiencia de Sevilla (1603), Edición facsimilar, Sevilla 1995

Dellaferrera, Nelson, Mónica Martini, Temática de las constituciones sinodales indianas. Arquidiócesis de la Plata, Instituto de Investigaciones de Historia del Derecho, Buenos Aires 2000

Dougnac Rodríguez, Antonio, Esquema del derecho de familia indiano, Santiago de Chile 2003

Duve, Thомas, La condición jurídica del indio y su consideración como persona miserabilis en el Derecho indiano, en: Losano, Mario (Ed.), Un giudice e due leggi. Pluralismo normativo e conflitti agrari in Sud America, Milano 2004, 3-33

Duve, Thomas, Los privilegios de los Indios: ¿derecho local?, en: Actas del XV Congreso del Instituto Internacional de Historia del Derecho Indiano (Córdoba, España 2005), Cordoba 2008, t. I, 111-130

Frigo, Daniela, Il padre di famiglia. Governo della casa e governo civile nella tradizione dell 'Economica' tra cinque e seicento, Roma 1985

Gacto, Enrique, El marco jurídico de la familia castellana. Edad Moderna, en: Historia. Instituciones. Documentos 11 (1984) 37-66

García-Gallo, Alfonso, Metodología de la historia del derecho indiano, Santiago de Chile 1970

Garriga, Carlos, Orden jurídico y poder político en el Antiguo Régimen, en: Garriga, C., M. Lorente, Cádiz 1812. La Constitución jurisdiccional, Madrid 2007

Gongora, Mario, Estudios de historia de las ideas y de historia social, Valparaíso 1980

Grossi, Paolo, Il dominio e le cose. Percezioni medievali e moderne dei diritti reali, Milano 1992

Hespanha, Antonio M., Cultura jurídica europea. Síntesis de un milenio, Madrid 2002

Hespanha, Antonio M., Vísperas del Leviatán. Instituciones y poder político. Portugal siglo XVII, Madrid 1989

Herzog, Tamar, Ritos de control, prácticas de negociación: Pesquisas, visitas y residencias en las relaciones entre Quito y Madrid (1650-1750), en: Gallego, José Andrés (coord.), Nuevas Aportaciones a la Historia Jurídica de Iberoamérica, Madrid: Fundación Histórica Tavera. Digibis Publicaciones digitales, 2000

Maravall, José Antonio, Estado moderno y mentalidad social. Siglos XV a XVII, 2 vols., Madrid 1972 
Mariluz Urquijo, José M., La comunidad de montes y pastos en el derecho indiano, en: Revista del Instituto de Historia del Derecho Ricardo Levene 23 (1972) 93-121

Martini, Mónica Patricia, Las constituciones sinodales indianas: entre la adecuación y la originalidad, en: Revista de Historia del Derecho 28 (2000) 377-400

Martiré, Eduardo, El derecho indiano, un derecho propio particular, en: Revista de Historia del Derecho 29 (2001) 331-362

Pihlajamäki, Heikki, Lo europeo en Derecho: Ius Politiae y el Derecho indiano, en: Barrios, Feliciano (coord.), Derecho y Administración Pública en las Indias Hispánicas, Actas del XII Congreso Internacional de Historia del Derecho Indiano, t. 2, Cuenca 2002, 1363-1375

Pugliese, María Rosa, El Derecho Indiano: perspectivas de lo local en el Virreinato del Río de la Plata. Con especial referencia a Buenos Aires y Montevideo, en: Actas y Estudios del XIV Congreso del Instituto Internacional de Historia del Derecho Indiano (Lima 2003), Lima 2008, t. 2, 337-352

Pugliese, María Rosa, Derecho local y gobierno local: la experiencia de Montevideo como gobierno periférico de Buenos Aires. Tensiones y relaciones en la formulación del derecho local en el Río de la Plata en la época indiana, en: Actas del XV Congreso del Instituto Internacional de Historia del Derecho Indiano (Córdoba, España 2005), Cordoba 2008, tomo I, 197-230

Pugliese, María Rosa, Apuntamientos sobre la aplicación del Derecho Indiano local en el Río de la Plata. Una creación jurídica empírica, en: Revista de Historia del Derecho 33 (2005) 219-295

SAnjurjo de Driollet, InÉs, Muy Ilustre Cabildo, Justicia y Regimiento. El cabildo de Mendoza en el siglo XVIII. Estudio institucional, Mendoza 1995

Sanjurjo de Driollet, Inés, La organización político administrativa de la campaña mendocina en el tránsito del Antiguo Régimen al orden liberal, Buenos Aires 2004

Sanjurjo de Driollet, InÉs, Las continuidades en el gobierno de la campaña mendocina en el siglo XIX, en: Revista de Estudios Históricos Jurídicos, Pontificia Universidad Católica de Valparaíso, Chile, 26 (2004) 445-468 (Versión impresa: ISSN 0716 5455; Versión electrónica: ISSN 0717 6260)

Sanjurjo de Driollet, Inés, Juan Bautista Alberdi: su visión de los cabildos indianos, en: Actas y Estudios, XIII Congreso del Instituto Internacional de Historia del Derecho Indiano, San Juan de Puerto Rico 2000, t. 1, 217-230

Sanjurjo de Driollet, InÉs, Nuevas perspectivas en la Historia del Derecho y de las Instituciones, en: Revista de Historia Americana y Argentina 41 (2007) $151-172$

Tau Anzoátegui, Víctor, Casuismo y Sistema. Indagación histórica sobre el espíritu del Derecho Indiano, Buenos Aires 1992

Tau Anzoátegui, Víctor, La Ley en América Hispana. Del Descubrimiento a la Emancipación, Academia Nacional de la Historia, Buenos Aires 1992 
Tau Anzoátegui, Víctor, Nuevos horizontes en el estudio histórico del Derecho Indiano, Instituto de Investigaciones de Historia del Derecho, Buenos Aires 1997

TAu Anzoátegui, Víctor, El poder de la costumbre. Estudios sobre el Derecho consuetudinario en América hispana hasta la Emancipación, CD-Rom, Ediciones DIGIBIS, Madrid 2000. Edición en papel: Instituto de Investigaciones de Historia del Derecho, Buenos Aires 2001

Tau Anzoátegui, Víctor, Los bandos de buen gobierno del Río de la Plata, Tucumán y Cuyo (época hispánica) (Edición y estudio). Instituto de Investigaciones de Historia del Derecho, Buenos Aires 2004

TAu Anzoátegui, Víctor, La variedad indiana, una clave en la concepción jurídica de Juan de Solórzano, en: Actas del II Congreso Iberoamericano de Academias de Historia, Madrid 1993, 475-488

TAu Anzoátegui, Víctor, La Monarquía: poder central y poderes locales, en: Academia Nacional de la Historia, Nueva Historia de la Nación Argentina, t. II, cap. 7, Buenos Aires 1999

TAu Anzoátegui, Víctor, Ordenes normativos y prácticas socio-jurídicas. La justicia, en: ídem, t. II, Cap. 9, Buenos Aires 1999

TAu Anzoátegui, Víctor, Las Indias ¿provincias, reinos o colonias? A propósito del planteo de Zorraquín Becú, en: Revista de Historia del Derecho 28 (2000) 77-137

Tau Anzoátegui, Víctor, La disimulación en el Derecho Indiano, en: Derecho y Administración pública en las Indias hispánicas. XII Congreso del Instituto Internacional de Historia del Derecho Indiano, Cuenca 2002, vol. II, 1733-1752

Tau Anzoátegui, Víctor, Poderes y Normas a través de un ejercicio de casuística indiana (Buenos Aires, 1714-1717), en: XIII Congreso del Instituto Internacional de Historia del Derecho Indiano. Actas y Estudios, San Juan de Puerto Rico 2003, t. I, 87-117

Tau Anzoátegui, Víctor, El Reino de Nápoles ¿un modelo de estudio para el Derecho indiano?, en: "Panta Rei". Studi dedicati a Manlio Bellomo, t. V, Roma 2004, 333-348

TAu Anzoátegui, Víctor, Una visión historiográfica del Derecho indiano provincial y local, en: XIV Congreso del Instituto Internacional de Historia del Derecho Indiano (Lima 2003), Lima 2008, 309-336

TAu AnzoÁtegui, Víctor, La potestad normativa en la ciudad durante la colonización española, en: Congreso Internacional "Mundus Novus. América Sistema Giurídico Latinamericano”, Roma 2003, 193-203

Tau Anzoátegui, Víctor, El Estudio del Derecho indiano provincial y local. Su base documental, en: Latin America in the Atlantic World c. 1500 - c. 1850. Essays in honor of Horst Pietschmann, Köln 2005, 83-96

Tau Anzoátegui, Víctor, La configuración del Derecho indiano Provincial y Local. Problemas terminológicos e históricos, en: XV Congreso del Instituto Interna- 
cional de Historia del Derecho Indiano. Córdoba (España), 2005. Manuel Torres Aguilar (coord.), t. I, 231-253

Thompson, E.P., Costumbres en común, Barcelona 1995

Vassallo, Jaqueline, Mujeres Delincuentes. Una mirada de género en la Córdoba del siglo XVIII. Centro de Estudios Avanzados, Córdoba 2006

Vassallo, Jaqueline, El discurso de la domesticidad en los alegatos judiciales de la Córdoba dieciochesca, en: Ghirardi, Mónica (comp), Cuestiones de Familia a través de las fuentes, Córdoba, Argentina 2005, 199-237

Zamora, Romina, Las mercedes de solares y la ocupación del espacio. San Miguel de Tucumán, 1745-1800, en: Boletín de la Junta de Estudios Genealógicos, dic 2004

Zamora, Romina, Los Autos de Buen Gobierno y el orden social. San Miguel de Tucumán, 1780-1810, en: Revista de Historia del Derecho 32 (2004) 443-470

Zamora, Romina, El vecindario y los oficios de gobierno en San Miguel de Tucumán en la segunda mitad del siglo XVIII, en: Revista de Historia del Derecho 35 (2007) 457-477

Zorraquín Becú, Ricardo, La condición política de las Indias, en: Revista de Historia de Derecho 2 (1974) 285-380

www.scielo.cl 



\section{Contributors}

Ezequiel Abásolo is Director of the History Department of the Faculty of Social Sciences at the Universidad Católica Argentina in Buenos Aires and 2nd Vice Director of the Instituto de Investigaciones de Historia del Derecho (INHIDE). His latest publication is Bastante más que 'degradantes andrajos de nuestra pasada esclavitud'. Fragmentos sudamericanos de la pervivencia de la cultura jurídica indiana durante el siglo XIX (2015). His main research interests focus on the transition from early Modern Latin American legal culture to that of the codification era. Further research areas include the circulation of ideas, normative experiences and products in Latin America during the 20th century, especially between Brazil and Argentina.

Thomas Duve is the Managing Director of the Max Planck Institute for European Legal History and Professor for Comparative Legal History at the Goethe University Frankfurt. His research focuses on the legal history of the early Modern Age and the Modern Era with particular interest in IberoAmerican legal history and the history of legal scholarship in the 20th century.

Rafael D. García Pérez is Associate Professor of Legal History and Researcher at the Institute for Culture and Society at the University of Navarra. He is author of "Antes leyes que Reyes". Cultura jurídica y Constitución política durante la Edad Moderna, Navarra, 1512-1808 (2008) and El Consejo de Indias durante los reinados de Carlos III y Carlos IV (1998). García’s current research interests include colonial law from the Old Regime to the 19th century as well as law and religion during the Atlantic Revolutions. He is member of the Instituto Internacional de Historia del Derecho Indiano.

Tamar Herzog is Monroe Gutman Professor of Latin American Affairs at Harvard University and is an affiliated faculty member in the Harvard Law School. Among her publications are the following books: Frontiers of Possession: Spain and Portugal in Europe and the Americas (2014), Upholding Justice: State, Law and the Penal System in Quito (2004, published in Spanish 1995 
and French 2001); Defining Nations: Immigrants and Citizens in Early Modern Spain and Spanish America (2003, Spanish translation 2006); Ritos de control, prácticas de negociación: Pesquisas, visitas y residencias (2000, French translation 2014); and Mediación, archivos y ejercicio: los escribanos de Quito (1996).

Marta Lorente is Professor of Legal History at the Autonomous University of Madrid. Her research has focused on the history of the Hispanic world, particularly on justice, constitutionalism and colonial issues. One of her latest works has been a book honoured by the Spanish Congress of Deputies (Lorente, Portillo, eds, El momento gaditano. La constitución en el orbe hispánico, 2012). Currently, she works on the history of international law.

Luigi Nuzzo is Professor of Legal History at the Law Faculty of the University of Salento (Lecce). In addition to having received several research grants at the Max Planck Institute for European Legal History (Frankfurt am Main), he was also Senior Robbins Research Fellow at the University of California at Berkeley, Alexander von Humboldt Fellow and Hauser Global Research Fellow at the New York University. He has published extensively on the history of international law, colonial law, the 'Spanish Indies' (16th17th centuries) as well as the German and Italian legal culture between the 19th and 20th centuries.

Brian P. Owensby is Professor in the Corcoran Department of History and Director of the Center for Global Inquiry and Innovation at the University of Virginia. He served as chair of the History Department from 2009 to 2013. $\mathrm{He}$ is the author of Intimate Ironies. The Making of Middle Class Lives in Modern Brazil (Stanford, 1999) and Empire of Law and Indian Justice in Colonial Mexico (Stanford, 2008). His current research interests include Jesuit juridical and political thought in the 18th century, the indigenous New World, and the challenges of historical imagination from a Latin American perspective.

Heikki Pihlajamäki is Professor of Comparative Legal History at the University of Helsinki. His research interests include the history of colonial law, commercial law and procedural law. 
Richard J. Ross is Professor of Law and History at the University of Illinois at Urbana/Champaign. His research interests center on the development of early American law in an Atlantic world and comparative early Modern framework. Work in this vein includes: "Legal Communications and Imperial Governance: British North America and Spanish America Compared," in The Cambridge History of Law in America, Vol. 1 (Cambridge, 2008); and Legal Pluralism and Empires, 1600-1850, co-edited with Lauren Benton (NYU Press, 2013). With Steven Wilf, he is at work on The Beginnings of American Law: A Comparative History (under contract, Yale University Press).

Víctor Tau Anzoátegui is an Honorary Researcher of The Argentinian National Research Council (CONICET) and head of the Instituto de Investigaciones de Historia del Derecho (INHIDE). He was a senior lecturer in legal history at the University of Buenos Aires. His research focus is on derecho indiano and Argentinian national law. Among his publications are Casuismo y Sistema. Indagación histórica sobre el espíritu del Derecho Indiano (1992) and La codificación en la Argentina (1810-1870). Mentalidad social e ideas jurídicas (2a edición, 2008). 



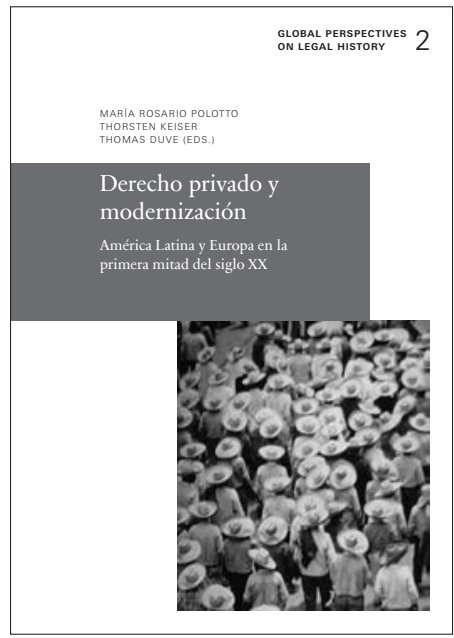

María Rosario Polotto, Thorsten Keiser, Thomas Duve (eds.)

Derecho privado y modernización América Latina y Europa en la primera mitad del siglo XX

Global Perspectives on Legal History 2

Frankfurt am Main: Max Planck Institute for European Legal History 2015.

VI, 315 S., € 16,61 D

ISBN: 978-3-944773-01-8

Open Access Online Edition:

http://dx.doi.org/10.12946/gplh2

The volume contains essays on the modernization of private law in Europe and Latin America from the viewpoint of legal history. Through a comparison between different forms of legal development in various normative und cultural contexts, the papers seek to open up new research perspectives on the concept of modernization in the field of private law.

\section{Contributors}

Alfons Aragoneses | Thomas Duve | Alfredo de J. Flores | Agostina Gentili | Thorsten Keiser | Mario Losano | Daniela Marino | Marcelo Neves | María Rosario Polotto | Maria Rosa Pugliese | Gustavo Silveira Siqueira | Alessandro Somma | Yolanda de Paz Trueba 
Global Perspectives on Legal History is a book series edited and published by the Max Planck Institute for European Legal History, Frankfurt am Main, Germany. As its title suggests, the series is designed to advance the scholarly research of legal historians worldwide who seek to transcend the established boundaries of national legal scholarship that typically sets the focus on a single, dominant modus of normativity and law.

The series aims to privilege studies dedicated to reconstructing the historical evolution of normativity from a global perspective.

It includes monographs, editions of sources, and collaborative works. All titles in the series are available both as premium print-on-demand and in the open-access format.

\section{Released volumes}

2 | María Rosario Polotto, Thorsten Keiser, Thomas Duve (eds.)

Derecho privado y modernización.

América Latina y Europa en la primera mitad del siglo XX

1 | Thomas Duve (ed.)

Entanglements in Legal History: Conceptual Approaches

More information on the series and forthcoming volumes: http://global.rg.mpg.de 



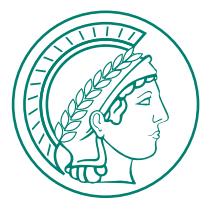

Derecho indiano, Spanish colonial law, has been a vigorous subdiscipline of legal history since the early 20th century. In 1997, in his Nuevos horizontes en el estudio histórico del derecho indiano, Argentinian legal historian Víctor Tau Anzoátegui considers some hitherto neglected perspectives. What has been achieved since then? What issues are being dealt with today? In this volume, scholars from different parts of the Western world address several of the current challenges confronting derecho indiano.

http://global.rg.mpg.de

ISBN 978-3-944773-02-5 